Débora Frigi Rodrigues

\title{
CARACTERIZAÇÃO POLIFÁSICA DA BIODIVERSIDADE DE ISOLADOS DEGRADADORES DE POLUENTES XENOBIÓTICOS NA BAIXADA SANTISTA
}

Dissertação apresentada ao Instituto de Ciências Biomédicas Para obtenção do título de Mestre em Ciências

Área de Concentração : Microbiologia Orientadora: Profa. Dra. Vivian Helena Pellizari

São Paulo

2002 
Com amor,

Aos meus pais, Vera e Caio, que sempre incentivaram meus estudos. Obrigada por serem sempre tão compreensivos e amáveis nos momentos difíceis. Saibam que, tudo que sou e tudo que conquistei eu devo a vocês.

À minha querida irmã Cibele e ao meu cunhado Marçal que sempre participaram de tudo mesmo estando longe, com conselhos, sugestões e com otimismo, trazendo sempre alegria.

Ao meu marido, Murillo, pelo seu otimismo, estímulo constante e paciência infinita. Obrigada pela ajuda e companheirismo durante a realização deste trabalho. 
- À Profa. Dra. Vivian Helena Pellizari, pela oportunidade de tê-la como orientadora, pelos valiosos ensinamentos, pela amizade e oportunidades que me proporcionaram crescimento profissional.

- À Profa. Dra. Rosalinda Montone, pelo apoio, carinho, conselhos e também pela agradável viagem a Antártica onde tive a oportunidade de ver como é uma pessoa maravilhosa.

- À Satie Tanigushi, que foi extremamente atenciosa nas dificuldades e análises cromatográficas dos PCBs.

- À Profa. Dra. Rosana Vazoller, à Profa. Dra. Irma Rivera, Dr. Gilson P. Manfio e Dra. Valéria Maia por toda atenção e valiosas sugestões durante o desenvolvimento da minha dissertação.

- À Fernanda F. Piza pela amizade, gentileza, dicas e valiosa ajuda na parte de Biologia Molecular. Saiba que suas dicas foram essenciais para o desenvolvimento deste trabalho.

- À Dra. Maria Inês Z. Sato e todo o pessoal da CETESB por todo o apoio, paciência e atenção que nos foi dada durante as coletas no estuário.

- À minha querida madrinha Myna Nakabashi, pelos conselhos, conversas, sugestões, carinhos e caminhadas matinais. Obrigada pela paciência que teve nos meus desabafos e reclamações, além dos excelentes conselhos, sugestões e orientações para a realização de minha dissertação.

- À Solange Sakata, pela ajuda e paciência durante os testes de biodegradação de hidrocarbonetos. Obrigada pela amizade e pelos fins de semana perdidos para me ajudar.

- À Hiroko e ao Celso da Seção de Pós-graduação com um atendimento todo especial cheio de atenção e carinho para com os alunos. 
- À Rosa Gamba, pela amizade, ajuda, carinho e atenção. Muito obrigada, pelo apoio e ajuda desde de quando eu era estagiária, saiba que muitas técnicas que aprendi eu devo a você. Obrigada também, pelas lições de vida e conselhos dados sempre em momentos oportunos.

- Ao Sr. Luiz e ao pessoal da sala de lavagem pela atenção e ajuda na preparação dos materiais nos momentos mais críticos do desenvolvimento do meu trabalho.

- Ao pessoal do laboratório de Microbiologia Ambiental, Luciane, Edna, Eveline, Fábio, Fernanda, Giovani, Anderson, Cristina, Adriana, Juliana, Keili, Gabriela, pela amizade e ajuda.

- As amigas Elisa, Ana Paula e Andréa pela amizade e pelos ensinamentos.

- Ao pessoal do laboratório do Instituto Oceanográfico, em especial para a Profa. Márcia Bícego e ao Gilvan pela amizade e ensinamentos.

- À Profa. Heloíza Barbosa pelos ensinamentos de microbiologia, e a quem devo muito por ter despertado em mim esta paixão pela microbiologia.

- Ao pessoal da Química Fina do Instituto de Química e ao Prof. Titular João Valdir Comasseto por permitir o uso do CG/MS.

- À FAPESP, pelo auxílio financeiro concedido.

- E a todos os que, de alguma forma contribuíram para que este trabalho ficasse melhor. 


\section{SUMÁRIO}

RESUMO

ABSTRACT

LISTA DE FIGURAS

LISTA DE TABELAS

1. INTRODUÇÃO E OBJETIVOS

1.1. Objetivos específicos 3

2. REVISÃO BIBLIOGRÁFICA 4

2.1. Hidrocarbonetos 4

2.1.1. Definições e origens dos hidrocarbonetos 4

2.1.1.1. Hidrocarbonetos biogênicos 6

2.1.1.2. Hidrocarbonetos petrogênicos $\quad 7$

2.1.1.3. Hidrocarbonetos antropogênicos 8

2.1.2. Impactos dos hidrocarbonetos do petróleo no ambiente 8

2.1.3. Degradação de hidrocarbonetos 9

2.1.3.1. Bioquímica da biodegradação bacteriana dos hidrocarbonetos 10

2.1.3.1.1. Bioquímica da biodegradação dos alifáticos 11

2.1.3.1.2. Bioquímica da biodegradação dos aromáticos 14

2.1.3.2. Genética da biodegradação dos hidrocarbonetos 25

2.1.4. Biodiversidade de microrganismos degradadores de hidrocarbonetos 32

2.2. Bifenilos Policlorados (PCBs) 35

2.2.1. Definições e origens dos PCBs 35

2.2.2. Impactos dos PCBs no ambiente $\quad 41$

2.2.3. Degradação de PCBs $\quad 42$

2.2.3.1. Degradação fotoquímica e combustão $\quad 42$

2.2.3.2. Bioquímica da biodegradação bacteriana de PCBs 42

2.2.3.3. Genética da biodegradação de PCBs 45

2.2.4. Biodiversidade de microrganismos degradadores de PCBs 48

2.3. Biogeografia e dispersão dos genes catabólicos 49

2.4. Revisão bibliográfica da área de estudo 51

2.4.1. Localização da Baía de Santos 51

2.4.2. Caracterização climática 52

2.4.3. Características geológicas e geomorfológicas 53

2.4.4. Dinâmica sedimentar no estuário e na Baía de Santos 53

2.4.5. Histórico da impactação ambiental na área $\quad 55$

2.4.6. Principais fontes de poluição $\quad 57$ 
3. MATERIAL E MÉTODOS 59

3.1. Pontos de coleta e método de amostragem 59

3.2. Caracterização das áreas estudadas 61

3.2.1. Parâmetros físico-químicos 61

3.2.2. Análise granulométrica dos sedimentos $\quad 62$

3.2.3. Análise química dos sedimentos $\quad 62$

3.2.4. Contagem de bactérias heterotróficas 65

3.3. Enriquecimento e isolamento de bactérias 65

3.4. Seleção de diferentes bactérias isoladas através da técnica de BOX-PCR 66

3.5. Amplificação dos genes catabólicos através da técnica de PCR 67

3.6. Amplificação parcial do gene 16SrRNA através da técnica de PCR 69

3.7. Teste de biodegradação de congêneres de PCBs 70

3.7.1. Obtenção e preparo das culturas bacterianas 70

3.7.2. Extração de PCBs das culturas $\quad 70$

3.7.3. Análise cromatográfica dos PCBs 71

3.8. Teste de biodegradação de hidrocarbonetos 72

3.8.1. Obtenção e preparo das culturas bacterianas $\quad 72$

3.8.2. Análise cromatográfica dos hidrocarbonetos 73

3.9. Caracterização taxonômica dos isolados 73

4. RESULTADOS 74

4.1. Caracterização das áreas estudadas $\quad 74$

4.1.1. Parâmetros físico-químicos $\quad 74$

4.1.2. Análise granulométrica dos sedimentos 75

4.1.3. Análise química dos hidrocarbonetos nos sedimentos 76

4.1.4. Análise química dos Bifenilos Policlorados (PCBs) nos sedimentos 82

4.1.5. Correlações das análises granulométricas com os poluentes $\quad 84$

4.1.6. Contagem de bactérias heterotróficas 84

4.2. Enriquecimento e isolamento das bactérias 85

4.3. Seleção de diferentes bactérias isoladas através da técnica de BOX-PCR 86

4.4. Amplificação dos genes catabólicos através da técnica de PCR 89

4.5. Amplificação parcial do gene 16srRNA através da técnica de PCR 92

4.6. Teste de biodegradação dos congêneres de PCBs 93

4.7. Teste de biodegradação de hidrocarbonetos 95

4.8. Caracterização taxonômica dos isolados 99

5. DISCUSSÃO 102

5.1. Caracterização das áreas estudadas 102

5.1.1. Parâmetros físico-químicos 102

5.1.2. Análise granulométrica dos sedimentos 104

$\begin{array}{lll}\text { 5.1.3. Análise química dos hidrocarbonetos nos sedimentos } & 104\end{array}$

5.1.4. Análise química dos Bifenilos Policlorados (PCBs) nos sedimentos 108

5.1.5. Contagem de bactérias heterotróficas $\quad 109$

5.2. Enriquecimento e isolamento de bactérias 110

5.3. Seleção de diferentes bactérias isoladas através da técnica de BOX-PCR 113 
5.4. Amplificação dos genes catabólicos através da técnica de PCR

5.5. Teste de biodegradação dos congêneres de PCBs

5.6. Teste de biodegradação dos hidrocarbonetos do petróleo

122

5.7. Caracterização taxonômica dos isolados

6. CONCLUSÕES

7. REFERÊNCIAS BIBLIOGRÁFICAS 


\section{RESUMO}

Produtos recalcitrantes como os bifenilos policlorados (PCBs) e hidrocarbonetos têm chamado a atenção de pesquisadores em diversas partes do mundo devido a sua persistência e efeitos nocivos ao meio ambiente e ao homem. O conhecimento da biodiversidade genotípica e fenotípica dos microrganismos degradadores de compostos xenobióticos é de grande importância para a compreensão dos aspectos ecológicos envolvidos na biodegradação microbiana; incluindo a dispersão geográfica das bactérias biodegradadoras que, pode também ser considerada e utilizada como modelo para a compreensão de padrões de distribuição geográfica de microrganismos autóctones do ambiente.

Devido a presença destes compostos na Baía de Santos é de grande interesse o presente estudo da diversidade microbiana de isolados neste ambiente. Este trabalho visou investigar a ocorrência e diversidade de bactérias capazes de degradar PCBs e hidrocarbonetos nas amostras coletadas no estuário de Santos. Para o estudo destas amostras foram utilizadas técnicas tradicionais de cultivo e análise química de degradação de hidrocarbonetos e PCBs. Técnicas de biologia molecular também foram aplicadas para estudar os diferentes perfis genotípicos obtidos por BOX-PCR. Além disso, foi verificada a presença de genes catabólicos nestes microrganismos e também foi realizada a identificação dos mesmos através da técnica de seqüenciamento do gene 16SrRNA.

Como resultado deste estudo, foram obtidos 61 isolados que foram submetidos à técnica de rep-PCR, empregando o iniciador BOX-A1R obtendo-se 30 amplificações com 28 padrões de bandas distintos. Esses isolados, foram então, testados para 6 genes catabólicos distintos, obtendo-se resultado positivo para os genes tod $\mathrm{C} 1$ (tolueno), ndoB (naftaleno), $x y l \mathrm{E}$ (xileno) e $b p h \mathrm{~A}$ (bifenilo). No entanto não foram observado genótipos distintos para as áreas afetadas. Nos testes de degradação foram obtidos 12 isolados degradadores de PCBs e 44 isolados degradadores de hidrocarbonetos. Nas análises de seqüenciamento do gene 16SrRNA, foram obtidos 11 gêneros distintos de bactérias, sendo 
que a maioria dos isolados se encontravam dentro do grupo filogenético de Proteobactéria na subdivisão Gama Proteobactéria.

A partir dos resultados de degradação, da pesquisa dos genes catabólicos e dos parâmetros físico-químicos, foi possível observar que a área estudada apresenta um forte potencial para biorremediação com microrganismos autóctones degradadores de hidrocarbonetos e PCBs. 
Recalcitrant compounds such as polychlorinated biphenyls (PCBs) and hydrocarbons have attracted researcher's attention all over the world, because of their persistence and side effects to the environment and to the humanity. The knowledge of genotypic an phenotypic biodiversity of xenobiotic compound degrading-microorganisms is extremely important for the comprehension of ecological aspects involved in microbial biodegradation; including the biodegrading-bacteria geographic dispersion that may also consider and provide a model for the comprehension of the patterns of geographic distribution of autochthonous microorganisms in the environment.

Because of the presence of these compounds in Santos Estuary, it is very important the present study of microbial diversity in this environment. The purpose of this work is to investigate the occurrence and the bacterial diversity that are able to degrade PCBs and hydrocarbons in samples of the Santos Estuary. For that, samples were collected and analyzed using traditional techniques of culturing and chemical analyses of PCBs and hydrocarbons biodegradation. Molecular Biology techniques were also used to determine the presence of catabolic genes, to study the different genotypic patterns of BOX-PCR and to identify the microorganisms.

As a result, 61 isolates were obtained, and then they were amplified with the BOXPCR primer resulting in 30 amplicons with 28 different band patterns. These isolates were then tested for 6 distinct catabolic genes with positive results for the tod $\mathrm{C} 1$ (toluene), ndoB (naphthalene), $x y l E$ (xylene) and $b p h \mathrm{~A}$ (biphenyl) genes. In the degradation tests, 12 PCBs degrading-isolates and 44 hydrocarbons degrading-isolates were obtained. As a result of the identification, was obtained 11 different genera of bacteria. Besides, most of the microorganisms belonged to the Gamma Proteobacteria subdivision. As a conclusion of these results and from the chemical and physical parameters studied in this work, was possible to notice that the studied area presents a noticeable potential for bioremediation with hydrocarbons and PCBs autochthonous degrading-microorganisms. 
Palavras-chave (Português): Biodiversidade microbiana, biodegradadores, poluição, estuário, Santos

Palavras-chave (inglês): Microbial biodiversity, Biodegrading-bacteira, polution, Estuary, Santos - Brazil 


\section{LISTA DE FIGURAS}

Figura 1: Exemplos de estruturas químicas representativas dos principais hidrocarbonetos do petróleo

Figura 2: Via metabólica do n-octano, realizado pela $P$. oleovorans (atual P. putida) (Wills et al., 2000)

Figura 3: Início da via de degradação do tolueno pela Pseudomonas putida F1 (Zylstra \& Gibson, 1991)

Figura 4: Vias de degradação do Tolueno pelas cepas Pseudomonas putida mt-2 (pTOL) e Pseudomonas mendocina (pWWO) respectivamente (Oh, 2000)

Figura 5: Vias de degradação do Tolueno pelas cepas Burhkolderia cepacia mt-2 (pTOL), Pseudomonas picketti G4, Pseudomonas putida F1 respectivamente (Zeng, 2001)

Figura 6: Vias de degradação do meta-xileno (1,3- dimetilbenzeno) pelas cepas Sphingomonas yanoikuyae B1 e Pseudomonas putida mt-2 (Hyatt \& Oh, 2000)

Figura 7: Vias de degradação do orto-xileno (1,2- dimetilbenzeno) pela cepa Burkholderia cepacia MB2 (Oh, 2000)

Figura 8: Via de degradação do para-xileno pela cepa Pseudomonas putida (Stephens, 2001).

Figura 9: Via de degradação do naftaleno pela cepa Pseudomonas putida (Oh, 2000).

Figura 10: Via de degradação do bifenilo e do meta-xileno pela cepa Beijerinckia sp. B1. Os genes codificam para enzimas responsáveis por cada passo da degradação, indicado cada gene uma enzima específica: $b p h \mathrm{~A}$-bifenilo dioxigenase; $b p h \mathrm{~B}$ - cis-2,3-dihidro-2,3dihidroxibifenilo desidrogenase; $b p h \mathrm{C}$ - 2,3-dihidroxibifenilo 1,2-dioxigenase; $b p h \mathrm{D}$ - 2hidroxi-6-oxo-6-fenilexa-2,4-dienoato hidrolase; $x l y \mathrm{AM}$ - xileno monoxigenase; $x l y \mathrm{~B}$ benzilaloalcool desidrogenase; $x y l \mathrm{C}$-benzilaldeído desidrogenase; $x y l \mathrm{D}$ (XYZ) toluato dioxigenase; $x y l$ L- 1,2-dihidroxi-3-metilciclohexa-3,5-dieno-carboxilato desidrogenase; e $x y l \mathrm{E}$ - catecol 2,3-dioxigenase. No caso do bifenilo o radical -R é um hidrogênio e para o m-xileno o radical -R é um grupo metila. TCA corresponde ao ácido tricarboxila (Kim \& Zylstra, 1995).

Figura 11: (A) Via de degradação do tolueno na $P$. putida F1. Produtos dos genes catalizando cada passo. (B) Organização genética dos genes de degradação do tolueno e genes vizinhos na P. putida F1 (Parales et al. 2000).

Figura 12: Passos da degradação do ácido 2,4- dichlorophenoxyacético (2,4-D). Catálize das enzimas sintétizadas por cada gene $t f d$ : $t f d \mathrm{~A}-2,4-\mathrm{D} \alpha$-keloglutarato dioxigenase; $t f d \mathrm{~B}_{(\mathrm{II})}$ 
- clorofenol hidroxilase; $t f d \mathrm{C}_{(\mathrm{II})}$ - clorocatecol 1,2- dioxigenase; $t f d \mathrm{D}_{(\mathrm{II})}$ - cloromuconato cicloisomerase; $t f d \mathrm{E}$ (II) - dienolactona hidrolase; $t f d \mathrm{~F}_{(\mathrm{II})}$ - (cloro)maleilactato redutase (Laemmli et al., 2000).

Figura 13: Organização bioquímica e genética do gene nah no cromossomo da $P$. stutzeri AN10 que codifica para a biotransformaçãodo naftaleno para acetil coenzima A. Cada gene codifica para uma enzima específica: nahA- naftaleno 1,2-dioxigenase ou nahWsalicilato hidroxilase; nahB - 1,2-dihidroxi-1,2- dihidronaftaleno desidrogenase; nahC 1,2-dihidroxi-naftaleno dioxigenase; nahD- 2-hidroxicromeno-2-carboxilato isomerase; nahE- tHBPA hidratase-aldolase; nahF- salicilaldeído desidrogenase; nahG- salicilato hidroxilase; $n a h \mathrm{H}$ - catecol 2,3-dioxigenase; nahI- semialdeído hidroximucônico desidrogenase; nahJ- 4-oxalocrotonato isomerase; $n a h \mathrm{~K}$ - 4-oxalocrotonato descarboxilase; nahL- 2-oxopenta-4-enoato hidratase; nahM- 2-oxo-4-hidroxipentanoato aldolase; nahOacetaldeído desidrogenase e $n a h \mathrm{~N}$ semialdeído hidroximocônico hidrolase (Bosch et al., 1999; Bosch et al., 2000)

Figura 14: Organização dos genes alk em diferentes microrganismos. Os genes que codificam para as enzimas alcano hidroxilases estão indicados em cinza, os genes da rubredoxina e rubredoxina redutase estão indicados em hachurado fino e grosso respectivamente. (A) Representação dos genes das Pseudomonas GPo1 e P. putida P1: alk $\mathrm{B}$ - alcano hidroxilase; alkF-rubedoxina 1; alk $\mathrm{G}$ - rubredoxina 2; alk $\mathrm{H}$ - aldeído desidrogenase; alkJ - alcóol desidrogenase; alkK- acil coenzima A sintetase; alkL- proteína de membrana externa; alkS- proteína regulatória; alk $\mathrm{T}$, rubredoxina redutase. (B) $A$. borkumensis $\mathrm{AP} 1$ : alkS - proteína regulatória putativa; alkB1- alcano hidroxilase; alkGrubredoxina; alkH- aldeído desidrogenase putativa; alkJ - alcóol desidrogenase putativa. (C) P. fluorescens $\mathrm{CHA}$, 'est $\mathrm{F} 1$-esterase; alkB- alcano hidroxilase; pra $\mathrm{A}$ e praBproteínas ativadoras da oxidação do alcano; omp $\mathrm{P} 1$ - proteína de membrana externa; yafH'acil CoA desidrogenase. (D) P. aeruginosa PAO1. PA2575-proteína hipotética; alkB1alcano hidroxilase; tlpS- proteína de quimiotaxia aceptora de metilas; hupR1- proteína regulatória da retirada de hidrogênio; PA 1526- proteína regulatória da família GntR; alkB2- alcano hidroxilase 2; $x d h \mathrm{~A}$, homólogo da xantina desidrogenase; glc EFG- proteínas hipotéticas; (E) P. rugosa NRRL B-2295: alkB- alcano hidroxilase; tetR- proteína regulatória putativada família da TetR; reg - proteína regulatória putativa. (F) $M$. tuberculosis H37Rv: MTCY20B11.28c- transportador catiônico; alkB- alcano hidroxilase; $r u b \mathrm{~A}$ - rubredoxina $1 ; r u b \mathrm{~B}$ - rubredoxina 2 ; tetR- proteína reguladora putativa da família TetR (Smits et al. 2002).

Figura 15: Estrutura molecular dos bifenilos policlorados (PCBs)

Figura 16: Estrutura de alguns congêneres de PCBs (Taniguchi, 1995).

Figura 17: Ciclo Ambiental dos PCBs (Pellizari, 1995).

Figura 18: Reação catalizada pela bifenilo dioxigenase. Os átomos de carbonos numerados, correspondem às possíveis posições em que o cloro pode substituir o hidrogênio (não está representado) nos bifenilos clorados; $o, m$ e $p$ denotam as posições orto, meta e para respectivamente. Cofatores enzimáticos e centros redox estão 
representados para cada componente da proteína. Abreviações: ISP, proteína ferro-enxofre; $\mathrm{Fd}$, ferrodoxina; Rd, redutase; ox, oxidado (Arnett et al., 2000).

Figura 19: Via metabólica do 4- clorobifenilo pela Pseudomonas sp. cepa LB400 (Chang \& Oh, 2000)

Figura 20: Via metabólica proposta para a degradação de bifenilo e organização genética do gene bph em Rhodococcus sp. RHA1. Correspondência dos genes com as emzimas: $b p h \mathrm{~A}$ - complexo da bifenilo dioxigenase, $b p h \mathrm{~B}$ - dihidrodiol desidrogenase; $b p h \mathrm{C}$ e etbC 2,3- DHBP 1,2-dioxigenase; $b p h \mathrm{D}$ - HOPD hidrolase; $b p h \mathrm{E}$ - 2, hidroxipenta-2,4-dienoato hidratase; $b p h \mathrm{~F}$ - 4-hidroxi-2-oxovalerato aldolase e $b p h \mathrm{G}$ - acetaldeído desidrogenase (Masai et al., 1997).

Figura 21: Foto aérea da área de estudo

Figura 22: Localização dos pontos de amostragem no estuário de Santos (SP).

Figura 23: (A) Coleta do sedimento com pegador de fundo de inox (Van Veen); (B) Transferência do sedimento coletado para frasco estéril para análise microbiológica

Figura 24: Fluxograma da extração e purificação das amostras de sedimento de Santos para análise cromatográfica

Figuras 25 a, b: Perfis genômicos gerados pela amplificação do iniciador BOXA1R dos DNAs dos isolados. Fotografia de géis de agarose a 1,5\% corado com brometo de etídio com uma corrida de 5V/cm. Figura 25a mostra a reprodutibilidade com Taq DNA Polimerase de 2 diferentes fornecedores (Gibco e Pharmacia) com diferentes isolados. Figura 25b mostra alguns dos diferentes perfis do BOXA1-R obtidos segundo a técnica de De Bruijn (1992). Os isolados do ponto 1 com hidrocarbonetos são: 1.1T-1.2T; isolado do ponto 1 com bifenilo: 1.2B; isolados do ponto 3 com hidrocarbonetos: $3.1 \mathrm{~T}-3.2 \mathrm{~T}-3.3 \mathrm{~T}$; isolados do ponto 4 com hidrocarboneto e bifenilo respectivamente: $4.1 \mathrm{~T}-4.2 \mathrm{~B}$; isolado do ponto 5 com hidrocarboneto: 5.2T; isolados do ponto 6 com hidrocarboneto: $6.1 \mathrm{~T}-6.5 \mathrm{~T}$; isolado do ponto 7 com hidrocarbonetos: 7.1T.

Figura 26: Dendrograma obtido a partir da análise de agrupamentos UPGMA dos perfis genômicos dos isolados bacterianos amplificados pelo BOXA1-R

Figura 27 a ,b ,c: Géis de agarose dos resultados dos PCRs dos genes catabólicos mostrando os padrões de bandas dos genes. - Figura 27b:1- Marcador de 100pb; 2- cepa $2.4 \mathrm{~T}$ com gene tod $\mathrm{C} 1$; 3 - cepa $1.2 \mathrm{~B}$ com gene tod $\mathrm{C} 1$; 4 - cepa $1.3 \mathrm{~B}$ com gene tod $\mathrm{C} 1$; 5cepa $1.4 \mathrm{~B}$ com gene tod $\mathrm{C} 1$; 6 - cepa $3.2 \mathrm{~T}$ com o gene ndo $\mathrm{B}$; 7- cepa $1.1 \mathrm{~B}$ com os genes xyl E e tod $\mathrm{C} 1$; 8- cepa $4.1 \mathrm{~T}$ com os genes nod $\mathrm{B}$ e tod $\mathrm{C} 1$; 9 - controles positivos com as cepas P. putida F1, ATCC 17484, ATCC 33015, com os genes xyl E, nod B e todC1. Figura 27c: Gel do PCR com algumas amostras: 1- Marcador de 100pb; 2- cepa 4.3T (resultado negativo para o iniciador do gene alkB); 3- cepa 4.3B (resultado negativo para o iniciador do gene alkB); 4- 1.6B (resultado negativo para o iniciador do gene alkB); 5- cepa 3.2B (resultado negativo para o iniciador do gene alkB); 6- Controle positivo para o gene 
alkB; 7- Controle positivo para o gene bphA; 8- cepa 5.4T (resultado negativo para o iniciador do gene bphA); 9- cepa 8.5B (gene bphA) ;10- cepa 8.1B (gene bphA); 11- cepa 3.2B (gene bphA); 12- Branco (gene bphA)

Figura 28: Exemplos de produtos de PCR do gene 16SrRNA em gel de agarose 1\%, corado com brometo de etídio. Estes produtos de PCR foram obtidos a partir dos DNAs de diferentes amostras amplificadas pelos iniciadores $27 \mathrm{f}$ e $1525 \mathrm{r}$, e pelos iniciadores $27 \mathrm{f} \mathrm{e}$ $1401 \mathrm{r}$ que produziram bandas com $1498 \mathrm{pb}$ e $1374 \mathrm{pb}$ respectivamente.

Figura 29: Cromatograma da biodegradação dos diferentes congêneres estudados pelo isolado 3.2B (A, controle bacteriano - células mortas; B- isolado degradador - células com atividade metabólica).

Figura 30: Cromatograma obtido para o padrão empregado no teste de degradação contendo tolueno, octano, xileno, nonano e naftalenona na concentração de $30 \mathrm{ppm}$

Figura 31: Cromatograma mostrando a degradação dos diferentes hidrocarbonetos estudados pelo isolado 8.1T .

Figura 32: Porcentagens dos gêneros encontrados no estuário de Santos 


\section{LISTA DE TABELAS}

Tabela 1. Características e exemplos dos principais hidrocarbonetos

Tabela 2. Distribuição de n-alcanos em bactérias, algas, zooplâncton e plantas terrestres

Tabela 3. Plasmídios envolvidos na biodegradação de compostos xenobióticos (Lynchie \& Hobbie, 1988)

Tabela 4. Sistema de numeração dos congêneres de PCBs

Tabela 5. Descrição dos pontos de amostragem realizados no estuário de Santos (SP).

Tabela 6. Seqüências de iniciadores e cepas - referências empregadas para cada gene catabólico estudado (Whyte, 1996).

Tabela 7. Reagentes e quantidades de reagentes utilizados na reação de PCR do multiplex

Tabela 8. Iniciadores empregados para a amplificação do gene 16S rRNA

Tabela 9. Reagentes e quantidades de reagentes empregados no PCR do 16S rDNA

Tabela 10. Resultados físico-químicos obtidos nos pontos de coletas e nas amostras coletadas

Tabela 11. Resultados da análise granulométrica dos sedimentos amostrados

Tabela 12. Concentrações de hidrocarbonetos alifáticos em sedimentos do Estuário de Santos e rios adjacentes, SP $\left(\mu \mathrm{g} \cdot \mathrm{g}^{-1}\right)$

Tabela 13. Concentrações de hidrocarbonetos alifáticos em sedimentos do Estuário de Santos e rios adjacentes, SP $\left(\mu \mathrm{g} \cdot \mathrm{g}^{-1}\right)$

Tabela 14. Concentrações de hidrocarbonetos aromáticos em sedimentos do Estuário de Santos e rios adjacentes, $\mathrm{SP}\left(\mu \mathrm{g} \cdot \mathrm{g}^{-1}\right)$

Tabela 15. Concentrações de hidrocarbonetos aromáticos em sedimentos do Estuário de Santos e rios adjacentes, $\mathrm{SP}\left(\mu \mathrm{g} \cdot \mathrm{g}^{-1}\right)$

Tabela 16. Concentrações de PCBs em sedimentos do Estuário de Santos e rios adjacentes, SP (ng. $\left.g^{-1}\right)$

Tabela 17. Coeficiente de correlação linear de Pearson entre concentrações totais dos poluentes e matéria orgânica do sedimento e porcentagens granulométricas para os sedimentos coletados no estuário de Santos 
Tabela 18. Resultados das contagens de bactérias heterotróficas obtidos nos sedimentos analisados

Tabela 19. Resultados do número de bactérias isoladas a partir dos consórcios enriquecidos em hidrocarbonetos e bifenilo nos diferentes pontos amostrados.

Tabela 20. Resultados obtidos através da técnica de PCR para a pesquisa dos 6 genes catabólicos nos 44 isolados com hidrocarbonetos

Tabela 21. Resultados obtidos através da técnica de PCR para a pesquisa dos 6 genes catabólicos nos 15 isolados com bifenilo

Tabela 22. Porcentagens de degradação dos diferentes congêneres com concentração de 10ppm pelos diferentes isolados.

Tabela 23. Resultados qualitativos do teste de degradação dos hidrocarbonetos xileno, tolueno, nonano e naftaleno pelos isolados do estuário de Santos.

Tabela 24. Resultados do seqüenciamento do gene 16SrRNA de 15 isolados com bifenilo obtidos no estuário de Santos.

Tabela 25. Resultados do seqüenciamento do gene 16SrRNA de 37 isolados com hidrocarbonetos obtidos no estuário de Santos. 


\section{INTRODUÇÃO E OBJETIVOS}

Produtos recalcitrantes como bifenilos policlorados (PCBs) e hidrocarbonetos têm chamado a atenção de pesquisadores em diversas partes do mundo devido a sua persistência e efeitos nocivos ao meio ambiente e ao homem. Por este motivo, houve a necessidade do conhecimento da biodiversidade genotípica e fenotípica dos microrganismos degradadores de compostos xenobióticos para se compreender os aspectos ecológicos envolvidos na biodegradação microbiana, proporcionando, desta forma, a biorremediação de locais impactados.

Tendo em vista que a biorremediação tem sido proposta como uma solução para atenuar problemas de contaminação ambiental através de microrganismos autóctones, torna-se cada vez mais necessário, o conhecimento e a compreensão da atividade, função metabólica e diversidade das comunidades microbianas, assim como os parâmetros ambientais (físicoquímicos) envolvidos neste processo, de forma a melhorar e estimular as taxas de degradação de compostos que estejam contaminando o ambiente.

A determinação da presença de genótipos catabólicos específicos, também tem um importante papel na obtenção de dados para determinar o potencial de uma área impactada para biorremediação, bem como servir de indicador de ecossistemas impactados. Além disso, o estudo dos genótipos catabólicos também proporciona a determinação da dispersão geográfica das bactérias biodegradadoras, servindo como modelo para a compreensão de padrões de distribuição geográfica de microrganismos autóctones do ambiente.

No Brasil, diversos autores já relataram a ocorrência de PCBs e hidrocarbonetos em sedimentos marinhos na região de Santos (Tommasi, 1985; Montone, 1987), bem como em organismos marinhos em Ubatuba e São Sebastião, no litoral paulista (Montone \& Weber, 1995) e na Baía de Todos os Santos, no litoral baiano (Tavares et al., 1988). Nogueira et al. (1987) constataram a presença de PCBs em tecidos adiposos humanos na população de São Paulo, comprovando a exposição da mesma a este poluente. Relatórios da Secretaria do Verde e do Meio Ambiente do Município de São Paulo (1995-1996) descreveram o estoque inadequado do óleo Askarel retirado de antigos transformadores, apresentando risco de contaminação ambiental. 
De maneira geral, a Baixada Santista também está sujeita ao impacto causado pelas numerosas indústrias localizadas na região. Dentre elas, destacam-se a indústria petroquímica, de produção de fertilizantes, siderúrgica e de transformação de recursos naturais. Neste local, desembocam os cursos d'água que drenam as áreas industriais de Cubatão, o cais da COSIPA, da ULTRAFÉRTIL, do Porto de Santos e do Entreposto de Pesca.

No Brasil, o primeiro estudo sobre biodegradação de PCBs com bactérias isoladas de amostras de solo e sedimento foi realizado por Pellizari et al. (1996). Os autores verificaram a capacidade de biodegradação de linhagens isoladas do Rio Pinheiros (SP) e de solo de Cubatão (SP), demonstrando o potencial destas áreas para biorremediação. Com esta constatação, Bertacini (1998) pesquisou pela primeira vez a presença de biodegradadores no estuário de Santos. A ocorrência de biodegradação de congêneres leves de PCBs por consórcios bacterianos no ponto do estuário afetado pela COSIPA, sugeriu a possibilidade de atividade para poluentes que causam maior impacto na região, os hidrocarbonetos de petróleo, visto que diversos hidrocarbonetos de petróleo são mais facilmente degradados do que PCBs.

No caso dos estudos com genes catabólicos no Brasil, bactérias degradadoras de naftaleno isoladas por Pellizari et al. (1996) foram comparadas por Tiedje et al. (1994) com isolados de países temperados. Os resultados sugeriram, que devido a falta de homologia encontrada a dispersão dos genes nah não seriam completas em países de clima tropical. Para ampliar este conhecimento Luz (2001), pesquisou diversos genes associados a degradação de hidrocarbonetos e organoclorados em DNA obtido a partir de amostras de solos de um aterro industrial de Cubatão onde obteve-se a presença de diversos genes catabólicos, havendo predominância do gene todC1. No entanto, este trabalho realizado por métodos diretos não avaliou nem a atividade metabólica para degradação testada através de cultivo, nem a diversidade de microrganismos degradores presentes nas amostras através de métodos polifásicos.

Portanto, o presente trabalho tem como objetivos estudar a ocorrência e a biodiversidade microbiana de isolados degradadores de PCBs e de hidrocarbonetos encontrados no estuário santista, avaliar a presença de genótipos catabólicos específicos e 
tentar correlacionar as comunidades microbianas obtidas com os diferentes fatores ambientais que impactam os diferentes pontos do estuário santista analisados.

\subsection{Objetivos específicos}

- Isolar diferentes microrganismos degradadores de PCBs e hidrocarbonetos de 9 pontos de coleta no estuário de Santos com diferentes grau de impactação.

- Selecionar os diferentes isolados através da técnica de BOX-A1R.

- Verificar a presença dos genes catabólicos alkB1, tfdC, ndoB, tod $\mathrm{C} 1, x y l \mathrm{E}$ e $b p h \mathrm{~A}$ nos diferentes isolados obtidos.

- Verificar o potencial de degradação dos isolados obtidos em bifenilo para diferentes congêneres de PCBs; assim como verificar o potencial de degradação dos isolados obtidos em óleo Diesel para os aromáticos e alifáticos selecionados que são: o nonano (n-alcano), tolueno (aromático), xileno (aromático) e naftaleno (poliaromático).

- Averiguar a relação dos diferentes fatores ambientais com a presença destes microrganismos no estuário. 


\section{REVISÃO BIBLIOGRÁFICA}

\subsection{Hidrocarbonetos}

\subsubsection{Definições e Origens dos hidrocarbonetos}

Os hidrocarbonetos são compostos apolares constituídos de moléculas de hidrogênio e carbono (Atkins \& Loretta, 2001) de natureza hidrofóbica que constituem a matéria orgânica presente em vegetais, animais e no petróleo (Figueiredo, 1999).

Os hidrocarbonetos estão amplamente distribuídos pelos continentes, oceanos e atmosfera (Connell \& Miller, 1984). No ambiente, as principais fontes desse composto são: a erosão de sedimentos, vazamentos de petróleo, os processos de combustão incompleta, as trocas atmosféricas, a drenagem urbana, combustão parcial de combustíveis (gás, madeira, carvão) utilizados para transportes, aquecimentos e geração de energia (GESAMP, 1993; Zanardi, 1996).

De acordo com Evans \& Rice (1974) e Gerlach (1981), os hidrocarbonetos podem ser classificados em alifáticos, cicloalifáticos e aromáticos. Na tabela 1 e figura 1 estão representados alguns hidrocarbonetos e suas características (Milanelli, 1994; Morrison \& Boyd, 1995).

Os hidrocarbonetos aromáticos são representantes mais tóxicos dessa classe, seguido pelos cicloalifáticos, olefinas e por último os alifáticos. Esta classificação de toxicidade está associada ao peso molecular desses compostos (Laws, 1993).

Os hidrocarbonetos aromáticos naturais são pouco freqüentes no ambiente marinho e quando encontrados estão em concentrações muito baixas (Schaeffer-Novelli \& Lacerda, 1992), por isso são utilizados como indicativos de poluição acidental (Zanardi, 1996). No sedimento marinho, os hidrocarbonetos estão sob a forma de misturas complexas originárias de múltiplas fontes. A discriminação das misturas é possível utilizando-se moléculas específicas que são denominadas de hidrocarbonetos marcadores geoquímicos (Figueiredo, 1999). 
Tabela 1. Características e exemplos dos principais hidrocarbonetos

\begin{tabular}{|c|c|c|}
\hline Hidrocarbonetos & Características & Exemplos \\
\hline Alifáticos & $\begin{array}{l}\text { - são mais leves que a água; } \\
\text { - quanto menor a molécula mais } \\
\text { volátil e hidrossolúvel é a } \\
\text { substância. }\end{array}$ & $\begin{array}{l}\text { Metano, propano, butano (que são } \\
\text { gases à temperatura ambiente); } \\
\text { pentano, etano e hexano, nonano } \\
\text { (líquidos a temperatura ambiente); } \\
\text { Os alifáticos sólidos são compostos } \\
\text { com } 16 \text { a } 60 \text { carbonos, ou mais, e } \\
\text { com mais de } 34 \text { hidrogênios }\end{array}$ \\
\hline Cicloalifáticos & $\begin{array}{l}\text { - são formados por até } 6 \text { átomos de } \\
\text { carbono arranjados em anel } \\
\text { - são compostos muito resistentes } \\
\text { à degradação bacteriana }\end{array}$ & $\begin{array}{l}\text { Ciclohexano, metilciclohexano, } \\
\text { metilciclopentano, } \\
\text { 1,2-dimetilciclopentano }\end{array}$ \\
\hline Aromáticos & $\begin{array}{l}\text { - são muito voláteis, relativamente } \\
\text { hidrossolúveis; são compostos que } \\
\text { se caracterizam pela presença do } \\
\text { anel benzênico } \\
\text { - alguns desses compostos podem } \\
\text { ser degradados por } \\
\text { microrganismos. }\end{array}$ & $\begin{array}{l}\text { Benzeno, benzopireno, naftaleno, } \\
\text { benzatraceno, bezantreno, tolueno, } \\
\text { xileno e fenantreno. }\end{array}$ \\
\hline
\end{tabular}<smiles>CCCCC</smiles>

\section{Butano} (alifático)<smiles>C1CCC1</smiles>

\section{Ciclopentano} (cicloalifático)<smiles>c1ccccc1</smiles>

Benzeno<smiles>c1ccc2ccccc2c1</smiles>

Naftaleno
(Aromáticos)

Figura 1: Exemplos de estruturas químicas representativas dos principais hidrocarbonetos do petróleo

As principais classes de hidrocarbonetos marcadores utilizados nos estudos geoquímicos em sedimentos marinhos são: n-alcanos, alcanos isoprenóides, biomarcadores de petróleo (terpanos, hopanos, e esteranos), alquil-benzenos lineares (LABs) e os policíclicos aromáticos (PAHs) (Medeiros, 2000).

Os hidrocarbonetos, dependendo de sua origem, podem ser classificados como sendo biogênicos, petrogênicos e antropogênicos (Linch \& Hobbie, 1988; Millero \& Sohn, 1991). 


\subsubsection{Hidrocarbonetos biogênicos}

Os hidrocarbonetos biogênicos são originários da biossíntese de organismos vegetais e animais (como a superfície cerácea das folhas, óleos vegetais, cutículas de insetos e lipídeos de microorganismos), da combustão da biomassa (decomposição), da diagênese de precursores naturais (como compostos orgânicos esteróides), da erosão de sedimentos continentais e da exudação de petróleo a partir de fendas nos fundos dos oceanos (UNEP, 1991).

No caso dos hidrocarbonetos biogênicos, os n-alcanos (alifáticos) são os compostos mais abundantes. Tanto organismos marinhos como terrestres sintetizam n-alcanos. Nesta síntese biológica há, geralmente, a predominância de cadeias de carbono com números ímpares. Também foi observado que, para cada espécie há compostos que são sintetizados com maior abundância, segundo tabela 2. As principais fontes biogênicas são as plantas terrestres, o fitoplâncton, o zooplanctôn e as bactérias. Os aportes naturais de origem continental são, maioritariamente, compostos por n-alcanos derivados de cêras cuticulares de plantas vasculares (Eglinton \& Hamilton, 1967).

Tabela 2. Distribuição de n-alcanos em bactérias, algas, zooplâncton e plantas terrestres

\begin{tabular}{|l|c|c|c|}
\hline Organismo & Ambiente & $\begin{array}{c}\text { Cadeia Carbônica } \\
\text { sintetizada pelo } \\
\text { organismo }\end{array}$ & $\begin{array}{c}\text { Composto dominante } \\
\text { sintetizado pelo } \\
\text { organismo }\end{array}$ \\
\hline Bactérias Fotossintéticas & Pelágico & $\mathrm{C}_{14}$ a $\mathrm{C}_{29}$ & $\mathrm{C}_{17}$ e $\mathrm{C}_{26}$ \\
Bactérias não-fotossintéticas & Bêntico & $\mathrm{C}_{15}$ a $\mathrm{C}_{29}$ & $\mathrm{C}_{17}-\mathrm{C}_{20}$ e $\mathrm{C}_{25}$ \\
Cianobactérias & Pelágico & $\mathrm{C}_{14}$ a $\mathrm{C}_{19}$ & $\mathrm{C}_{17}$ \\
Fitoplâncton & Pelágico & $\mathrm{C}_{15}$ a $\mathrm{C}_{21}$ & $\mathrm{C}_{17}$ \\
Macroalgas Pardas & Bêntico & $\mathrm{C}_{13}$ a $\mathrm{C}_{26}$ & $\mathrm{C}_{15}$ \\
Macroalgas vermelhas & Bêntico & $\mathrm{C}_{15}$ a $\mathrm{C}_{24}$ & $\mathrm{C}_{17}$ \\
Zooplâncton & Pelágico & $\mathrm{C}_{18}$ a $\mathrm{C}_{34}$ & $\mathrm{C}_{18}$ e $\mathrm{C}_{24}$ \\
Plantas Vasculares & Terrestre & $\mathrm{C}_{15}$ a $\mathrm{C}_{37}$ & $\mathrm{C}_{27}, \mathrm{C}_{29}$ e $\mathrm{C}_{31}$ \\
\hline
\end{tabular}

Fonte: Philp, 1985

Quanto aos compostos aromáticos biogênicos, de maneira geral, os pigmentos e os compostos triterpenóides são os principais precursores naturais. Os mais abundantes são o perileno e os derivados aromáticos de compostos diterpenóides e compostos triterpenóides pentacíclicos (Figueiredo, 1999). Outros exemplos de compostos de origem biogênicas 
incluem: perileno, uma série de homólogos do fenantreno; reteno e primantreno e derivados de diterpenos.

\subsubsection{Hidrocarbonetos petrogênicos}

Os hidrocarbonetos petrogênicos são os hidrocarbonetos do petróleo, sendo classificado desta maneira devido a forma como foram produzidos. A explicação mais aceita, pelos geólogos, para a origem do petróleo é que este é formado pela decomposição de restos de plantas e animais, o produto desta decomposição é em seguida transformado sob alta pressão e temperatura em petróleo ( Speer \& Whithehead, 1969).

Devido a diferentes condições de transformação e de constituição da matéria orgânica decomposta, cada óleo formado terá diferentes características físicas e químicas. Em outras palavras, o petróleo pode apresentar cerca de 200 a 300 componentes químicos diferentes, sendo que essa mistura complexa contém muitos tipos de poluentes potenciais (Hood et. al., 1971; Milanelli, 1994; Zanardi, 1996). Dos compostos presentes no petróleo até 98\% são hidrocarbonetos (Clark \& Brown, 1977; Bícego, 1988). Existem outros constituintes secundários importantes, que são os compostos de enxofre (até 10\%) e ácidos graxos (até 5\%), contendo ainda, alguns elementos a níveis traço como níquel, vanádio, ferro, alumínio, urânio, cobre, sódio e cálcio (Weber, 1981; Bícego, 1988; Zanardi, 1996). No caso dos hidrocarbonetos presentes no petróleo encontram-se os alifáticos, cicloalifáticos e os aromáticos. A quantidade destes compostos é variável, assim como a presença de metais e de outros compostos orgânicos. Em geral, a maior fração de hidrocarbonetos alifáticos são alcanos, que podem ser lineares ou ramificados, possuindo de 1 a mais de 40 carbonos. Compostos alifáticos insaturados estão geralmente mais presentes em produtos refinados. Nos compostos alifáticos monocíclicos há prevalência de ciclopentanos e ciclohexanos, os demais cicloalifáticos são geralmente alquil-substituídos. Em relação aos compostos aromáticos, estes podem possuir um ou mais anéis benzênicos. Ainda há frações de compostos com alto peso molecular, que são designadas "asfaltenos" ou "resinas", constituídas de Nitrogênio, oxigênio e enxofre (Atlas, 1981; Morgan \& Watkinson, 1994). 


\subsubsection{Hidrocarbonetos antropogênicos}

Os hidrocarbonetos antropogênicos são provenientes das atividades humanas. Estes possuem grande importância devido ao seus efeitos carcinogênicos, mutagênicos e tóxicos a um grande número de invertebrados, peixes, pássaros e mamíferos (Kennish, 1992).

Desde a Revolução Industrial houve um significativo aumento do uso do petróleo e seus derivados pelo homem, devido a sua aplicação bastante diversificada. Como exemplo, podemos citar o uso na indústria de cosméticos, de artefatos plásticos, de automóveis, entre outros. O intenso uso de produtos derivados do petróleo fez com que o petróleo se tornasse uma das principais fontes de hidrocarbonetos antropogênicos, principalmente próximo a áreas urbanas (Connell \& Miller, 1984).

Esta extensiva exploração petrolífera e a atividade antrópica levou a um acúmulo de hidrocarbonetos à níveis indesejáveis no ambiente. Isto devido aos acidentes com navios, rupturas de oleodutos, operações negligentes de carga e descarga nos terminais, lavagem dos tanques de petróleo com água do mar, transporte atmosférico dos componentes mais voláteis de petróleo e seus refinados, a geração de energia através de carvão e petróleo, a combustão parcial de combustíveis em transportes, queimas de florestas, efluentes domésticos e industriais, entre outros (Skinner \& Turekian, 1977; Nipper,1990; Zanardi , 1996).

\subsubsection{Impactos dos hidrocarbonetos do petróleo no ambiente}

O grau de impacto sobre as comunidades biológicas de uma descarga, tanto acidental quanto crônica, pode ser determinado de acordo com o tipo de processo de degradação que o petróleo sofre, com o tempo que leva para que a degradação ocorra, das características químicas e composição do petróleo, a persistência no ambiente (consequentemente sua biodisponibilidade) e sua área de distribuição (Milanelli, 1994; Bícego, 1996).

Para determinar a extensão do dano ecológico, provocado por um derramamento, deve-se considerar a degradação do óleo e a distância da costa (Laws, 1993). 
Schaeffer-Novelli (1990) ressalta que a vulnerabilidade dos ecossistemas expostos ocasionalmente a um derramamento são distintas e nem todos os produtos de petróleo são igualmente tóxicos. Mas a gravidade de um derramamento vai depender da área atingida, e de algumas características como a quantidade de atividades ligadas á área (por exemplo a navegação e a aquicultura) e o nível de industrialização (GESAMP, 1993).

Algumas conseqüências que podem estar relacionadas com um derramamento ou acidente de petróleo (Clark, 1986; Zanardi, 1996): perda da estética ambiental; impacto à vida marinha; prejuízo as atividades econômicas associadas a pesca, ao turismo e a exploração dos recursos do mar; interferência nas atividades recreacionais humanas, como a pesca, natação, mergulho e navegação, entre outros.

Apesar de todas essas conseqüências da contaminação ambiental por hidrocarbonetos de petróleo, ainda existem diversos estuários no mundo todo que estão sofrendo este tipo de impacto. Além disso, diversos estudos de impactos em estuários têm sido realizados demonstrando que locais próximos a centros urbanos e locais industrializados tendem a sofrer um maior impacto com hidrocarbonetos de petróleo, como foi mostrado nos trabalhos que falam do impacto de hidrocarbonetos em estuários na China (Zheng \& Richardson, 1999; Yang, 2000), Alemanha (Witt \& Trost, 1999) e no estuário próximo ao mar Mediterrâneo (Bouloubassi \& Saliot, 1993). Estes trabalhos confirmam que a proveniência dos hidrocarbonetos são de transportes marítimos, descarga de esgotos, água de percolação de chuvas, derrames de petróleo, entre outros. Demonstraram também que é importante o estudo de hidrocarbonetos no sedimento, tanto para identificar a origem destes hidrocarbonetos, como para saber o impacto que a área está ou esteve sofrendo.

\subsubsection{Degradação de hidrocarbonetos}

Existem uma série de fatores aos quais a oxidação do óleo no ambiente é dependente, tais como: composição química do óleo, dispersão na água, temperatura, concentração de nutrientes inorgânicos, salinidade e abundância de espécies de microrganismos (Connell \& Miller, 1984). Por exemplo, as baixas temperaturas aumentam a viscosidade do óleo derramado e inibem a mistura do óleo na água (GESAMP, 1993). 
O petróleo, após ocorrido o derramamento, pode sofrer diversos processos de degradação por ações físicas, químicas ou biológicas, favorecendo a sua decomposição, diluição ou precipitação.

Por exemplo, quando o petróleo ou seus produtos derivados são introduzidos no ambiente marinho, ocorrem mudanças nas suas propriedades físicas e químicas, como resultado de vários processos simultâneos de remoção e degradação. Primeiramente, ocorre o espalhamento do óleo pela superfície da água e o seu transporte pelo vento, correntes, ondas e ação de marés. Os compostos com pontos de ebulição mais baixos evaporam a uma taxa que é influenciada pela velocidade do vento, temperatura da água e do ar e estado do mar. Uma emulsão óleo-aquosa pode se formar, podendo conter de 20 a 80\% de água e, a partir daí, os demais compostos tendem a ser dissolvidos. Apesar da parte dissolvida representar uma pequena fração do óleo, sua importância é grande devido ao seu efeito tóxico da emulsão em sistemas biológicos. Parte do óleo é incorporado ao material particulado ou aos organismos, para depois sedimentar. Pode ocorrer ainda, a degradação microbiológica que vai depender da diversidade e densidade das populações de microrganismos e da concentração de oxigênio e nutrientes (Jordan \& Payne, 1980). A fração dissolvida também pode ser fotoxidada e os produtos resultantes, por serem mais solúveis, dispersam-se mais facilmente na coluna d'água (NRC,1985).

Enquanto na água os derrames de petróleo sofrem um espalhamento horizontal, os derrames terrestres são caracterizados pelo movimento vertical. A infiltração do óleo no solo previne a perda de hidrocarbonetos voláteis por evaporação, os quais podem ser tóxicos aos microrganismos. A matéria particulada pode reduzir, por absorção, a toxicidade efetiva dos componentes do petróleo, mas a absorção e adsorção de hidrocarbonetos por substâncias húmicas podem contribuir para a formação de resíduos persistentes (Courseuil, 1994).

\subsubsection{Bioquímica da biodegradação bacteriana dos hidrocarbonetos}

A biodegradação de hidrocarbonetos envolve diferentes genes e enzimas específicas para os diferentes compostos que os compõe. A capacidade de degradar e a via de degradação de um determinado composto varia de um microrganismo para outro. Além disso, as enzimas de degradação são altamente específicas, tanto para as reações catalisadas 
quanto na seleção do substrato utilizado, por isto, para cada tipo de hidrocarboneto existe um grupo de enzimas envolvidos na degradação. Segundo Leahy \& Colwell (1990), a biodegradação bacteriana e fúngica de hidrocarbonetos alifáticos, cicloalifáticos e aromáticos é realizada inicialmente, por enzimas chamadas oxigenases. Tendo em vista que o oxigênio molecular tem duas funções principais: a primeira como aceptor final de elétrons para que possa ocorrer a liberação de elétrons durante as reações metabólicas; e a segunda como oxidante direto do anel aromático, para a realização das oxidações microbianas são necessárias condições aeróbias. Geralmente, em camadas superficiais da coluna d'água, tanto em ambientes de água doce como marinhos, não há limitações de oxigênio. Contudo, nos sedimentos aquáticos apenas uma fina camada superficial do sedimento é aeróbia, isto, dependendo dos parâmetros físico-químicos do local e da atividade microbiológica que podem gerar um ambiente anóxico (Alexander, 1994). Entretanto, a degradação anaeróbia de hidrocarbonetos aromáticos no ambiente já foi observada, mas ainda é muito pouco conhecida (Langenhoff et al, 1996).

A degradação aeróbia dos compostos do petróleo, pode representar um grande desafio para os microrganismos, tendo em vista que compostos de baixo peso molecular podem apresentar alta toxicidade devido a seus efeitos solventes nas membranas celulares dos microrganismos, e também devido as implicações das propriedades físicas destes componentes, pois alguns hidrocarbonetos podem ser líquidos ou sólidos nas temperaturas ambiente e também são pouco solúveis em água (Morgan \& Watkinson, 1994). A solubilidade destes compostos diminui rapidamente com o aumento do peso molecular, dificultando desta forma a utilização destes hidrocarbonetos como substratos.

Para entender melhor a degradação microbiológica aeróbia no presente estudo, é importante entender como se dá a degradação dos alifáticos, assim como dos aromáticos, salientando algumas vias metabólicas mais estudadas como as do tolueno, xileno e naftaleno.

\subsection{Bioquímica da biodegradação dos alifáticos}

Como os alifáticos compreendem os n-alcanos, alcanos ramificados e cicloalcanos, as vias de degradação não são idênticas entre eles. Para os n-alcanos, que são considerados 
os hidrocarbonetos mais facilmente degradáveis, foi demonstrada a biodegradação de até nC44 (Linch \& Hobbie, 1988; Morgan \& Watkinson, 1994; Haines \& Alexander, 1974).

Segundo Linch \& Hobbie (1988), n-alcanos de cadeia longa são degradados mais rapidamente do que os homólogos de cadeia curta, isto porque os alcanos de cadeia curta possuem alta solubilidade e toxicidade para os microrganismos. Em geral, a biodegradação de n-alcanos ocorre pelo ataque monoterminal, havendo formação de um álcool primário através de uma enzima hidroxilase (monoxigenase), seguido por um aldeído e um ácido monocarboxílico, (Linch \& Hobbie, 1988; Mackenna \& Kallio, 1964; Miller \& Johnson, 1966; Van der Linden \& Thijsse, 1965), por sua vez, o ácido carboxílico é degradado via $\beta$ oxidação com a formação de ácidos graxos com dois carbonos a menos e com a formação de acetil-coenzima A, havendo eventual liberação de $\mathrm{CO}_{2}$. No geral, as enzimas envolvidas na biodegação de n-alcanos já estão bem caracterizadas, principalmente as álcool e aldeído desidrogenases. Estas enzimas podem estar solúveis ou ligadas à membrana bacteriana e necessitam de NAD + ou NADP + como cofatores. Algumas destas enzimas podem ser induzíveis ou constitutivas e podem exibir uma ampla faixa de substratos. No caso de leveduras e fungos filamentosos, as desidrogenases, são descritas na literatura, como NADdependentes e apresentam a mesma variabilidade (Morgan \& Watkinson, 1994).

Um exemplo de degradação de n-alcanos é o n-octano (figura 2), que é um dos representantes dos n-alcanos. O n-octano é um composto usado em síntese orgânica, calibrações e em destilações azeotrópicas e é um composto comum na gasolina e em diversos outros compostos derivados do petróleo. Muitos organismos, incluindo diversas Pseudomonas, são capazes de usar alcanos lineares como sua única fonte de carbono e energia. (Beilen et al., 1994). Isômeros ramificados como o isooctano são menos susceptíveis a biodegradação do que o n-octano (Schaeffer, 1979).

A conversão do n-octano para 1-octanol é catalisado por um grupo de proteínas chamadas de "sistema alcano hidrolase". Este sistema contém 3 principais componentes: a alcano 1- monoxigenase e duas proteínas solúveis a rubredoxina e a rubredoxina redutase. A rubredoxina redutase transfere elétrons do NADH para a rubredoxina Esta proteína, então transfere elétrons para a alcano 1- monoxigenase, uma enzima localizada na membrana citoplasmática. O produto final da via, o octanoil-CoA, entra no ciclo da betaoxidação e é usado tanto como fonte de carbono, como de energia (Beilen et al., 1994). O 
sistema de enzima redutase alcil hidroperóxido da Salmonella choleraesuis (antiga $S$. typhimurium) é composta de 2 enzimas ( $a h p \mathrm{C}$ e $a h p \mathrm{~F}$ ) que reduz em hidroperóxidos orgânicos e peróxido de hidrogênio (Poole 1996). Homólogos destas enzimas são encontradas em uma variedade de espécies de bactérias Gram-positivas e Gram-negativas.

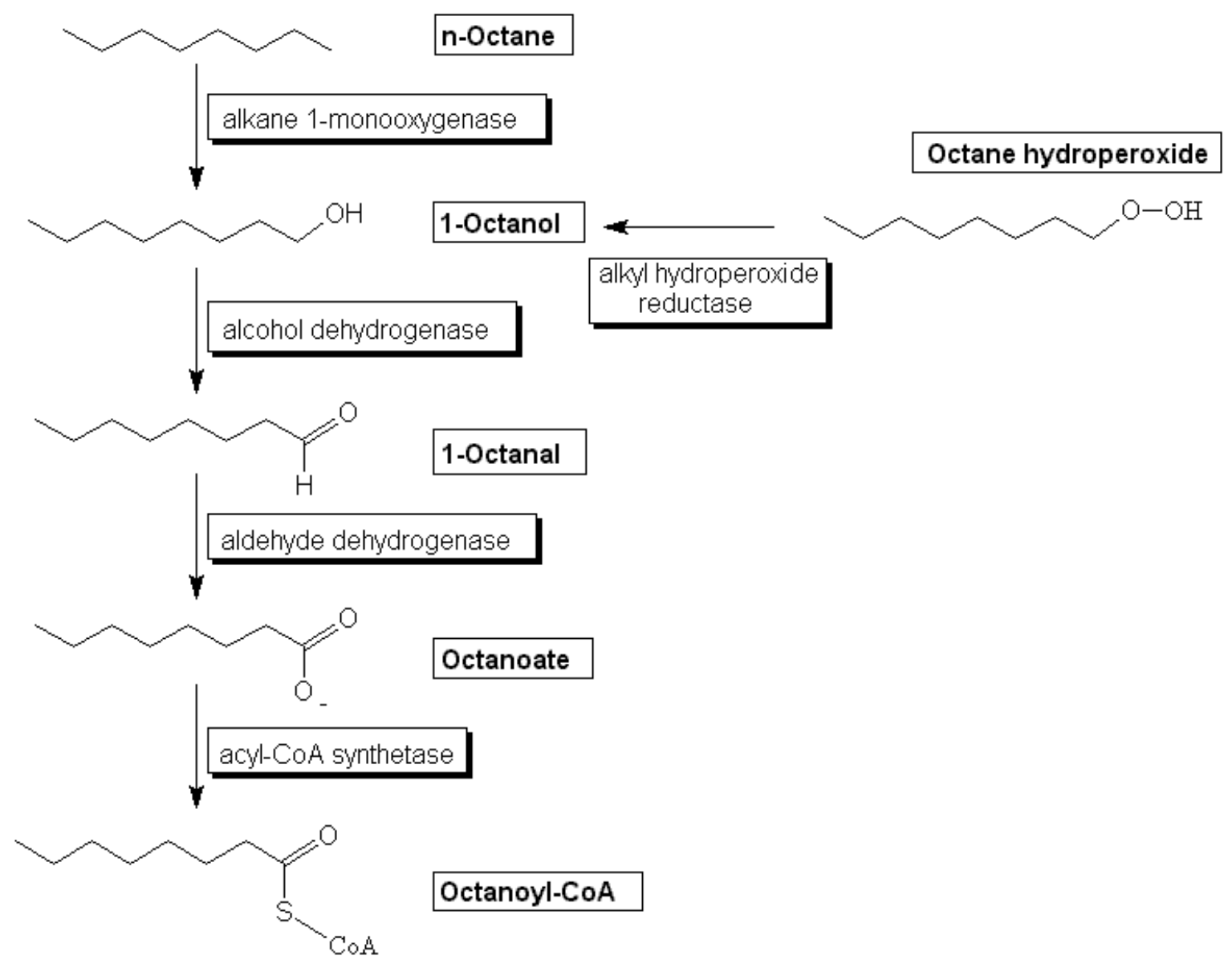

Figura 2: Via metabólica do n-octano, realizado pela P. oleovorans (atual P. putida) (Wills et al., 2000)

Nos primeiros estágios de biodegradação dos alcenos, são produzidos óxidos, dióis e álcoois primários, secundários e insaturados. Como no caso dos alcanos, os alcenos também apresentam diversas monooxigenases envolvidas nestas reações (Linch \& Hobbie, 1988).

Os cicloalcanos e os alcanos ramificados, por serem recalcitrantes, têm degradação mais lenta e tendem a ser preterida em relação ao dos n-alcanos que são mais facilmente degradados. Os cicloalcanos geralmente envolvem degradação através de cometabolismo, sendo realizado por populações mistas. No cometabolismo, estas moléculas são convertidas 
à álcoois ou cetonas, por monoxigenases de baixa especificidade. $\mathrm{O}$ ataque a molécula, pode ocorrer tanto na cadeia lateral como na cadeia cíclica, dependendo do microrganismo e do substrato (Linch \& Hobbie, 1988; Morgan \& Watkinson, 1994) .

\subsection{Bioquímica da biodegradação dos Aromáticos}

Os compostos aromáticos se caracterizam pela presença do anel benzênico, considerada uma das estruturas químicas mais comuns, pois é encontrada em diversos produtos orgânicos naturais. Diversos hidrocarbonetos aromáticos são utilizados na fabricação de produtos farmacêuticos, polímeros, explosivos, óleos e solventes industriais, entre outros.

Nos últimos 30 anos, foi possível elucidar as vias metabólicas utilizadas por diversos organismos na biodegradação de compostos aromáticos, assim como identificou-se os metabólitos intermediários e os sistemas enzimáticos (Smith, 1994). Compostos com até 3 anéis aromáticos são degradados facilmente e há linhagens capazes de degradar compostos com até cinco anéis aromáticos. Tipicamente, a degradação bacteriana envolve a ação de uma dioxigenase que insere oxigênio molecular no anel benzênico formando dihidrodiol. Nesta primeira hidroxilação, em geral, ocorre consumo de energia. Os compostos intermediários gerados são então transformados por uma via de orto-clivagem ou de meta-clivagem por dioxigenases sem o consumo de energia, resultando na formação de catecol. Este, por sua vez, é catabolizado pela enzima catecol 1,2 dioxigenase e subseqüentemente pela catecol 2,3- sendo por sua vez convertido em ácido tricarboxílico por outra dioxigenase (Smith, 1994; Van der Meer et al., 1993; Linch \& Hobbie, 1988).

Para melhor exemplificar a bioquímica da degradação dos aromáticos serão utilizados algumas vias metabólicas já conhecidas, como a do tolueno, xileno e naftaleno.

O conhecimento da via metabólica do tolueno ou metilbenzeno é importante tendo em vista o fato de ser um dos compostos do BTEX (benzeno, tolueno, etilbenzeno e xilenos), sendo amplamente utilizado na indústria como solvente e considerado como um dos produtos do petróleo mais abundante e impactante no ambiente. Além disso, a via de degradação do tolueno já está muito bem estudada no aspecto molecular e também serve de modelo para compreender os mecanismos bacterianos de metabolismo do anel benzênico. 
Atualmente, são conhecidas 5 vias metabólicas distintas para a degradação aeróbia do tolueno (Figuras 4 e 5). Suas vias consistem basicamente na inserção de 2 átomos de oxigênio no anel aromático para formar o catecol que é o substrato da clivagem do anel benzênico ( Zeng, 2001).

As vias de degradação pela Pseudomonas putida mt-2 (pTOL), é codificada pelo plasmídio TOL, esta via, envolve a oxidação do grupo metila para formar o ácido benzóico. Este é subsequentemente, transformado em cis-benzoato dihidrodiol que é desidrogenado formando o catecol e em seguida, clivado na via de meta-clivagem. No caso da via de degradação da Pseudomonas mendocina ( $\mathrm{pWWO}$ ), também realizado por uma variante do plasmídio TOL, o tolueno é primeiro hidroxilado para formar $p$-cresol que é então oxidado no grupo metila para forma o $p$-hidroxibenzoato. Subseqüentemente o anel é novamente hidroxilado para formar o protocatecuato que servirá de substrato para a via de ortoclivagem do anel aromático (Figura 4) (Zylstra \& Gibson, 1991).

$\mathrm{Na}$ figura 5, estão representadas as outras 3 vias metabólicas do tolueno. A via representada pela Burhkolderia cepacia mostra que o tolueno é primeiramente hidroxilado na forma de $o$-cresol (4-hidroxitolueno), que é novamente hidroxilado para formar o 3metil-catecol. Este último composto é então, degradado na via de meta-clivagem. O primeiro passo do metabolismo da Pseudomonas picketti G4 é também uma hidroxilação do anel benzênico ( Parales et al., 2000). Contudo, neste caso a hidroxilação do tolueno ocorre em uma posição diferente do anel para produzir o m-cresol. A subsequente hidroxilação leva a formação do 3-metilcatecol. Na via de degradação da Pseudomonas Putida F1, o primeiro passo da degradação, envolve a formação do cis-1,2-dihidroxi3metilciclohexa-3,5-dieno (tolueno cis-dihidrodiol). Esta reação é catalisada por um sistema enzimático multicomponentes chamado tolueno dioxigenase. A flavoproteína, designada como redutase $_{\mathrm{ToL}}$, inicialmente capta életrons da NADH. A enzima reduzida chamada redutase $_{\mathrm{ToL}}$ transfere életrons para a $2 \mathrm{Fe} .2 \mathrm{~S}$ ferrodoxina, chamada de ferrodoxina $\mathrm{ToL}_{\mathrm{To}}$. A Ferrodoxina ${ }_{\mathrm{TOL}}$, em retorno, reduz a proteína terminal ferro-enxofre, chamada de ISP $\mathrm{T}_{\mathrm{TOL}}$ que funciona como componente da oxigenase. O ISP ${ }_{\mathrm{TOL}}$ reduzido então, catalisa a adição do oxigênio no núcleo aromático para formar o tolueno cis-dihidrodiol. O dihidrodiol é então, desidrogenado em uma reação dependente de $\mathrm{NAD}^{+}$pela tolueno cis-dihidrodiol 
desidrogenase para forma o 3-metilcatecol, como representado na figura 3 (Zylstra \& Gibson, 1991; Zylstra \& Gibson, 1989).

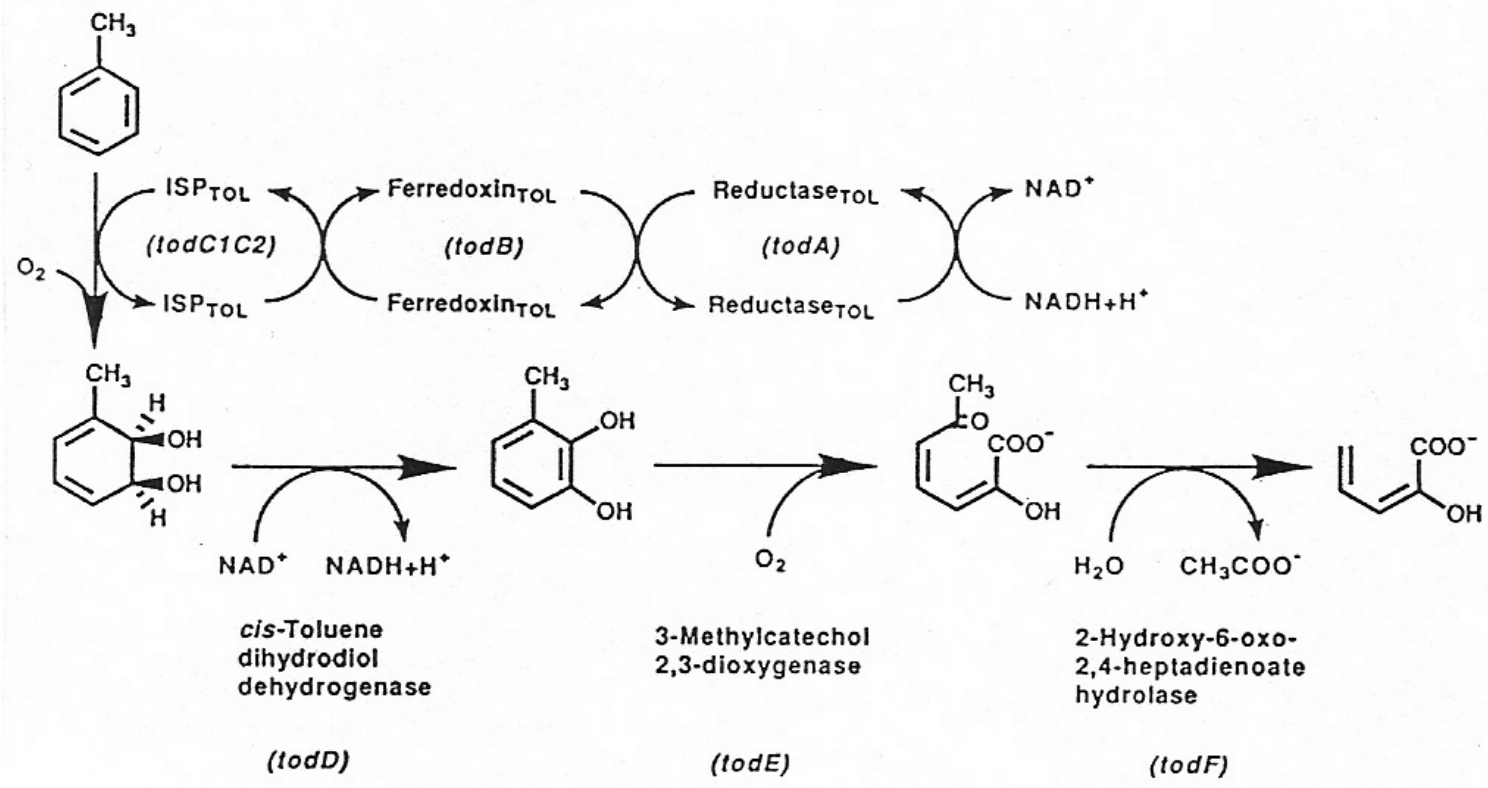

Figura 3: Início da via de degradação do tolueno pela Pseudomonas putida F1 (Zylstra \& Gibson, 1991) 


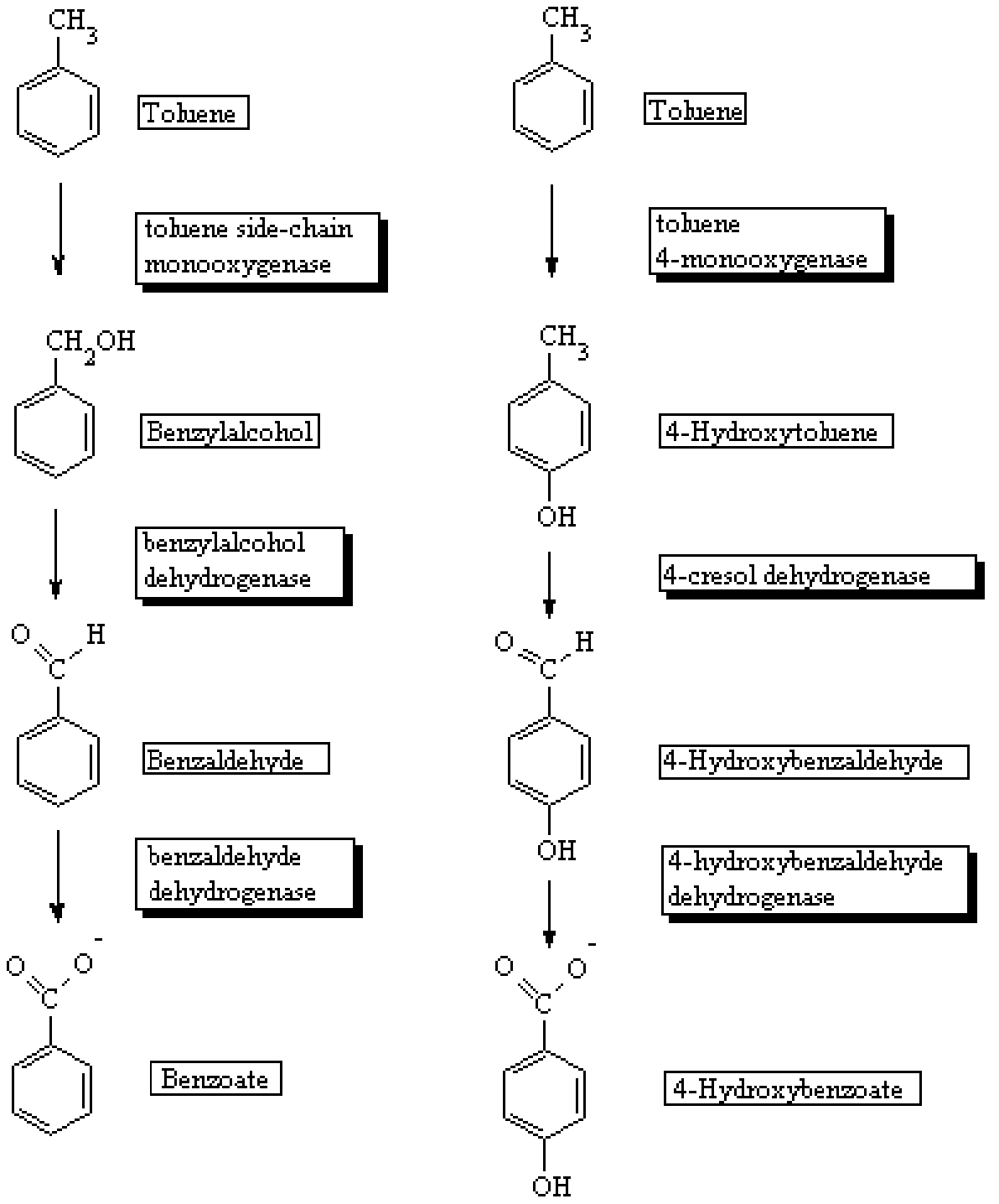

Figura 4: Vias de degradação do tolueno pelas cepas Pseudomonas putida mt-2 (pTOL) e Pseudomonas mendocina (pWWO) respectivamente (Oh, 2000) 


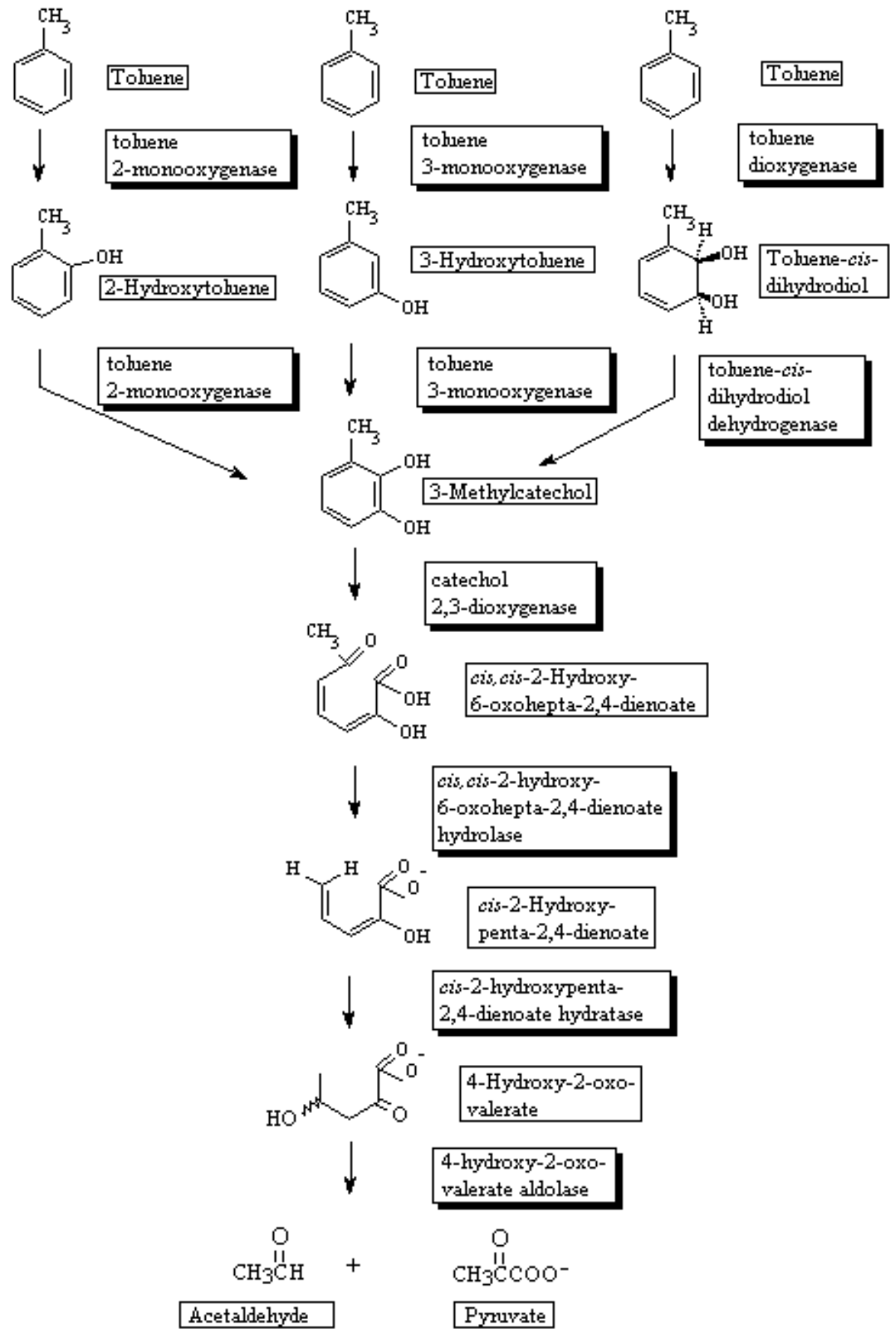

Figura 5: Vias de degradação do tolueno pelas cepas Burhkolderia cepacia mt-2 (pTOL), Pseudomonas picketti G4, Pseudomonas putida F1 respectivamente (Zeng, 2001)

Outro composto de importante destaque é o xileno ou dimetilbenzeno que também possui um único anel benzêno e pertence ao grupo de compostos do BTEX, sendo obtidos a partir do petróleo. O xileno é um poluente importante devido a sua fácil entrada na 
atmosfera durante a combustão da gasolina. Quando ocorre o derramamento de gasolina ou de outros combustíveis do petróleo no solo, o xileno é um composto relativamente móvel que pode chegar a contaminar águas subterrâneas. Quando introduzido em altas concentrações nas águas subterrâneas, este composto pode persistir por vários anos. Dependendo da localização do substituinte no anel benzênico o xileno pode ter o prefixo orto-, para- e meta-. O meta-xileno é usado principalmente como solvente. Já o orto-xileno tem maior utilidade na manufatura de ftlálicos anidro, pequenas quantidades deste composto também são usadas como solventes e na fabricação de bactericidas, herbicidas de soja e óleos lubrificantes. O para-xileno é utilizado na produção do ácido tereftalico (PTA) para a produção de fibras de poliester, resinas e filmes. Alguns para-xilenos são usados também como solventes e na produção de di-paraxileno e herbicidas.

A via metabólica do meta-xileno é realizada tanto pela Sphingomonas yanoikuyae B1 como pela Pseudomonas putida mt-2 e está descrita na figura 6.

Segundo Jorgensen et al. (1995) a oxidação do o-xileno ocorre através do álcool $o$ metilbenzil, $o$-metilbenzaldeído e do $o$-metilbenzoato. A remoção deste composto depende, da degradação simultânea do tolueno. Higson \& Focht (1992) verificaram que a degradação do 2-metilbenzoato para 3-metilcatecol ocorre através da composto carboxi-hidrodiol pela dioxigenação. A representação da via de degradação do $o$-xileno se encontra na figura 7 .

No caso da via do para-xileno (figura 8), as enzimas catabólicas tem mostrado uma especificidade muito similar a do tolueno, para-xileno e meta-xileno. Davey \& Gibson (1974) demonstraram que o para-xileno é degradado para 4-metilcatecol pela oxidação do substituinte metila para um grupo álcool e pela adição de um outro grupo álcool. Murray \& Duggleby (1972) descreveram que o 4-metilcatecol é degradado pela via de meta-clivagem, na qual o 4-metilcatecol é clivado na posição meta. Gunther \& Schlosser (1994) também contribuiram para a via deste composto, demonstrando que o 4-metilcatecol é também degradado pela via de orto-clivagem para 4-metilmuconolactona como produto final. 


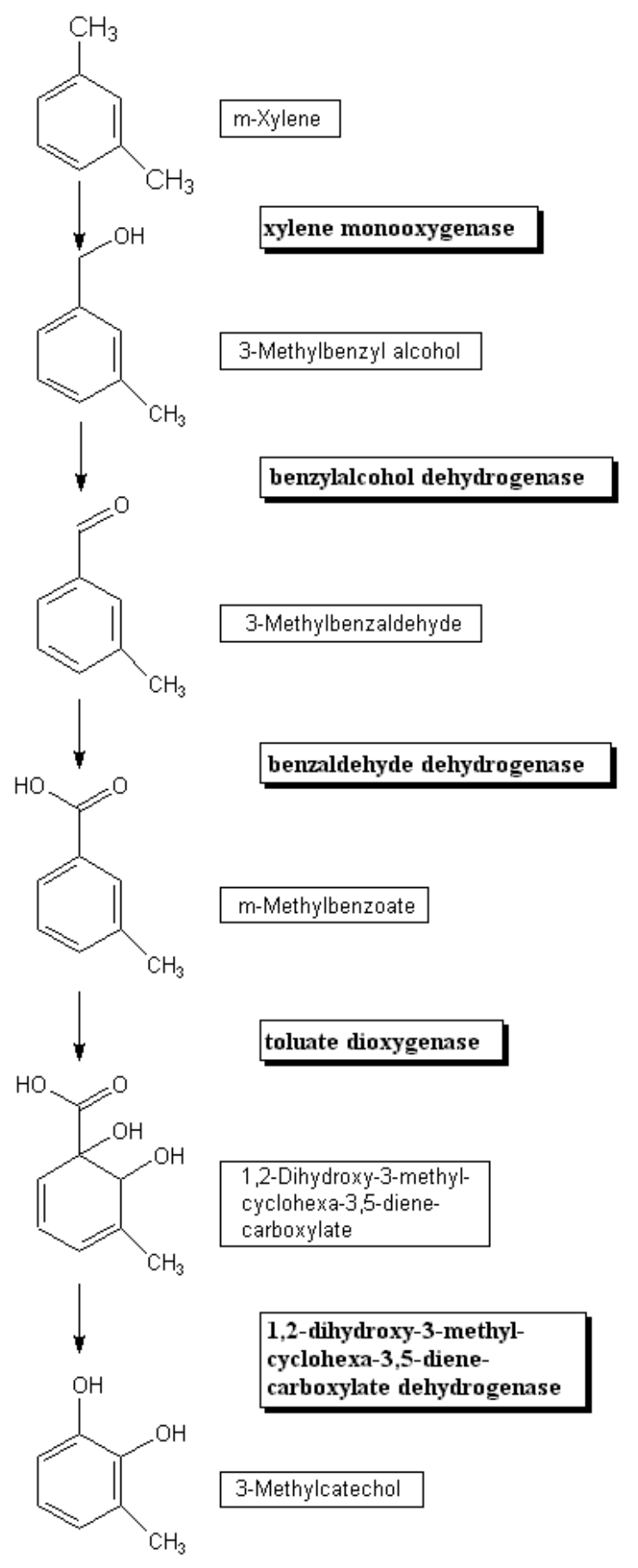

Figura 6: Vias de degradação do meta-xileno (1,3-dimetilbenzeno) pelas cepas Sphingomonas yanoikuyae B1 e Pseudomonas putida mt-2 (Hyatt \& Oh, 2000) 


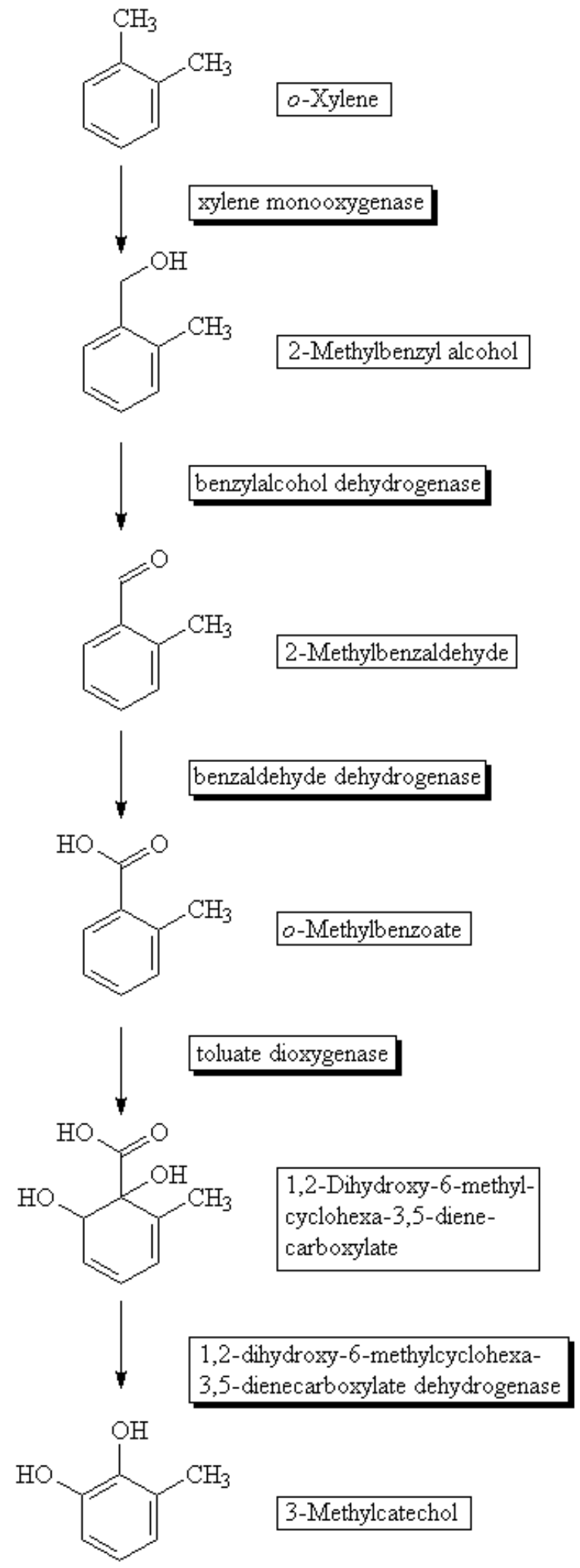

Figura 7: Vias de degradação do orto-xileno (1,2- dimetilbenzeno) pela cepa Burkholderia cepacia MB2 (Oh, 2000) 

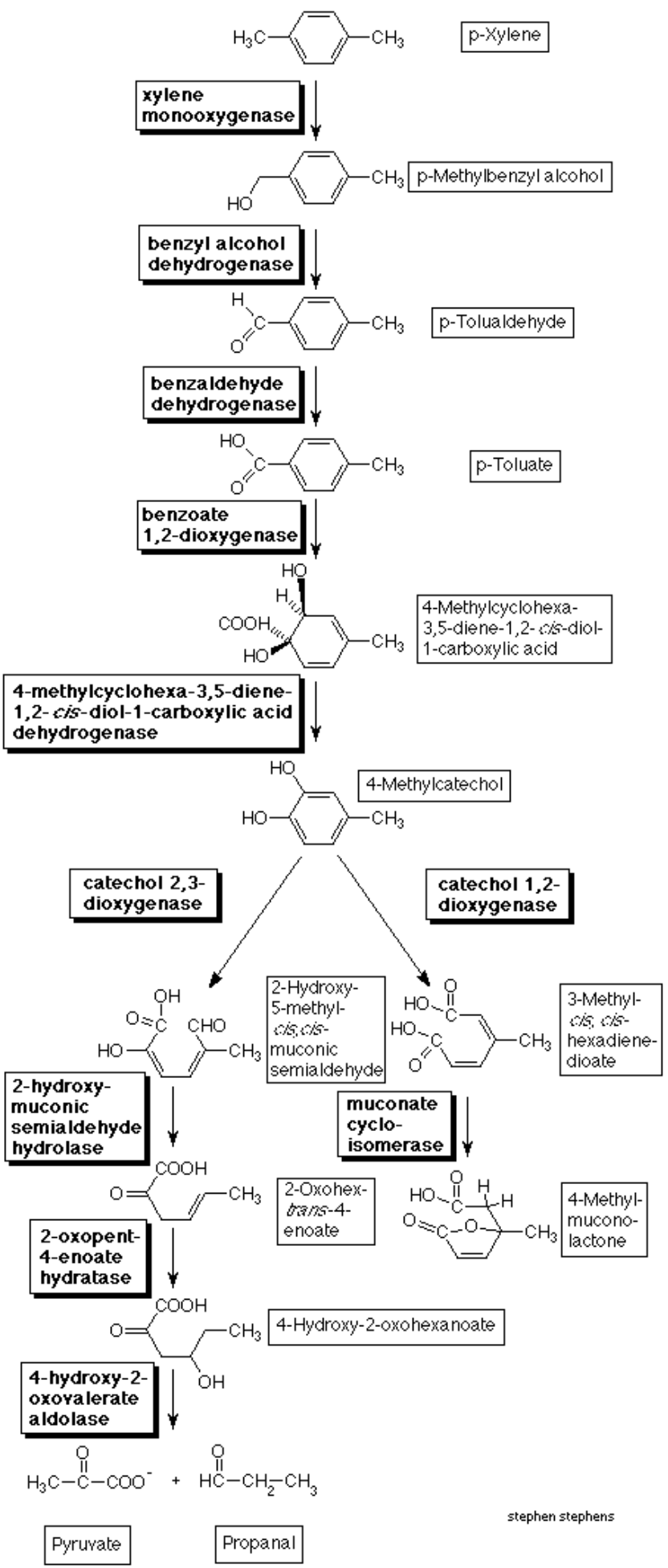

Figura 8: Via de degradação do para-xileno pela cepa Pseudomonas putida (Stephens, 2001). 
A via de degradação do naftaleno é de grande interesse visto que é um hidrocarboneto que contém 2 anéis aromáticos fundidos servindo desta forma como modelo para um melhor entendimento das propriedades de amplas classes de hidrocarbonetos aromáticos policíclicos (PAHs) que são bastante abundantes no ambiente.

O naftaleno e seus derivados substituídos são frequentemente encontrados em óleo bruto e em produtos do petróleo. Certos PAHs são considerados altamente cancerígenos para o homem, sendo desta forma, considerados de grande interesse a degradação microbiana destes compostos.

A enzima naftaleno dioxigenase que inicia o metabolismo bacteriano do naftaleno é usada em muitos processos biotecnológicos, inclusive para a síntese da tinta azul índigo para jeans.

Como em todos os PAHs, a primeira enzima da via de degradação é uma dioxigenase, que converte o hidrocarboneto aromático em seu correspondente cisdihidrodiol (Hamann et al., 1999). A naftaleno dioxigenase é uma proteína multimérica consistindo de uma redutase, a ferrodoxina e 2 subunidades de proteína ferro-enxofre (Eaton \& Chapman, 1992). As dioxigenases responsáveis pelo primeiro passo na oxidação aeróbia de hidrocarbonetos de baixo peso molecular (como naftaleno, bifenilo, benzeno e outros) tem muitas similaridades, sugerindo que estas dioxigenases tenham origem evolutiva comum, porém distante (Harayama \& Kok, 1992; Mason \& Cammack, 1992).

A via metabólica do naftaleno, encontra-se na figura 9. 


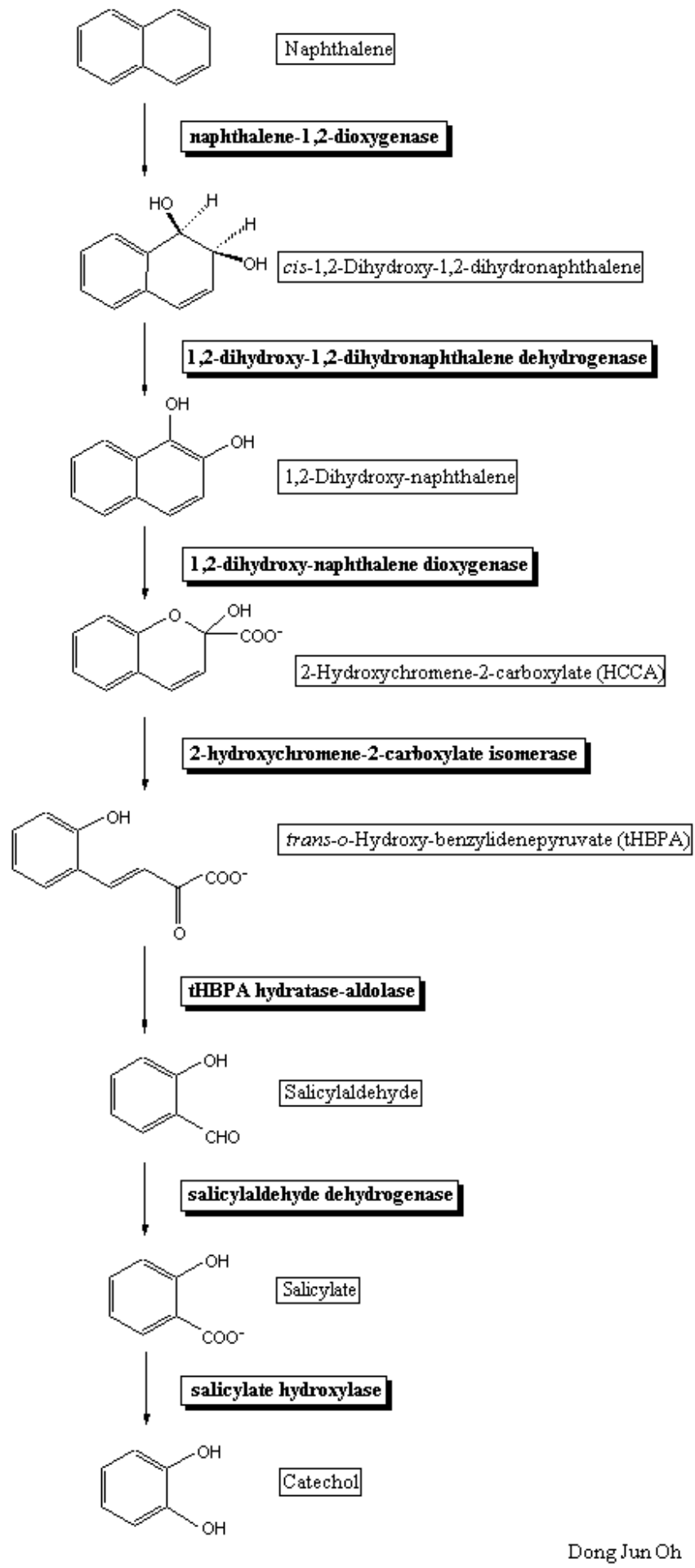

Figura 9: Via de degradação do naftaleno pela cepa Pseudomonas putida (Oh, 2000). 


\subsubsection{Genética da biodegradação dos hidrocarbonetos}

A genética de biodegradação está diretamente relacionada aos mecanismos de adaptação da comunidade microbiana, visto que a transferência gênica e a mutação de genes são essenciais para a metabolização de poluentes químicos (Barkay \& Pritchard, 1988 e Spain \& van Veld, 1983). Monitoramentos diretos dos processos que dizem respeito a adaptação de hidrocarbonetos foram possíveis através do desenvolvimento de sondas específicas de DNA para os genes codificadores das vias metabólicas dos hidrocarbonetos (Trevor, 1985). Sayler et al. (1985), por exemplo, usando a técnica de hibridação de colônia, demonstrou a correlação entre o aumento de taxas de mineralização de hidrocarbonetos poliaromáticos (PAH) em sedimentos contaminados com óleo e o aumento de número de colônias contendo seqüências de DNA que hibridavam com os plasmídios TOL (oxidação do toluato) e NAH (oxidação do Naftaleno).

Segundo Leahy \& Colwell (1990), os plasmídios tem um importante papel na adaptação genética de microrganismos, visto que estes representam uma forma de DNA altamente móvel que pode ser transferida via conjugação ou transformação. Segundo Frantz \& Chakrabarty (1986), o isolamento e a caracterização primária dos primeiros plasmídios possuindo genes que codificavam para enzimas catabólicas foi descrito no início dos anos 70 por grupos de pesquisadores dos Estados Unidos e do Reino Unido. A partir daí, o número de plasmídios catabólicos aumentou bastante. Na literatura, já existem descrições da presença de plasmídio envolvidos na degradação de alcanos (como o octano, decano), clorobifenilos, naftaleno, tolueno, xileno, toluato, etilbenzeno e muitos outros compostos. A representação de alguns destes plasmídios se encontra na tabela 3.

Um dos primeiros plasmídios a serem isolados foi o plasmídio TOL. Os plasmídios TOL foram isolados em espécies de pseudomonas por vários grupos no mundo todo, sendo o pWWO o principal arquétipo do plasmídio TOL. O plasmídio TOL possui genes reguladores que codificam para enzimas que catalizam a conversão de 1,2,4trimetilbenzeno, meta e para-xileno, tolueno entre outros. Atualmente, 15 genes catabólicos já foram mapeados no plasmídio pWWO, incluindo dois genes reguladores ( $x y l \mathrm{~S}$ e $x y l \mathrm{R})$ que controlam positivamente dois promotores. Os genes estruturais são organizados em 2 operons, o $x y l \mathrm{CAB}$ e o $x y l \mathrm{XYZLEGFJIH,} \mathrm{estes} \mathrm{são} \mathrm{controlados} \mathrm{por} \mathrm{dois} \mathrm{genes} \mathrm{reguladores}$ 
que provavelmente interagem de alguma maneira para que ocorra a indução completa dos dois operons (Lynchie \& Hobbie, 1988). Na figura 10, é possível observar onde os genes $x y l$ atuam na via de degradação do meta-xileno.

Tabela 3. Plasmídios envolvidos na biodegradação de compostos xenobióticos

\begin{tabular}{|l|c|c|l|l|}
\hline \multicolumn{1}{|c|}{ Compostos } & Plasmídio & $\begin{array}{c}\text { Tamanho } \\
\text { (kbp) }\end{array}$ & $\begin{array}{c}\text { Hospedeiro } \\
\text { original }\end{array}$ & \multicolumn{1}{|c|}{ Referência } \\
\hline $\begin{array}{l}\text { Alcanos (octano, } \\
\text { decano) }\end{array}$ & OCT & $>500$ & $\begin{array}{l}\text { Pseudomonas } \\
\text { putida }\end{array}$ & $\begin{array}{l}\text { Owen (1986); Shapiro } \text { et } \\
\text { al. (1984) }\end{array}$ \\
\hline Clorobifenilo & pKF1 & 81 & Acinetobacter sp. & $\begin{array}{l}\text { Furukawa \& Chakrabarty } \\
(1982)\end{array}$ \\
\cline { 2 - 5 } & pSS50 & 56 & Alcaligenes sp. & Shieds et al. (1985) \\
\hline Naftaleno & NAH & 83 & $\begin{array}{l}\text { Pseudomonas } \\
\text { putida }\end{array}$ & Yen \& Gunsalus (1985) \\
\hline $\begin{array}{l}\text { Tolueno, xileno, } \\
\text { toluato, } \\
\text { etilbenzeno, } \\
\text { trimetiltolueno }\end{array}$ & TOL & 117 & $\begin{array}{l}\text { Pseudomonas } \\
\text { putida }\end{array}$ & $\begin{array}{l}\text { Ensley (1984); Nakazawa } \\
\text { \& Inouye (1986); Yen \& } \\
\text { Gunsalus (1985) }\end{array}$ \\
\hline
\end{tabular}

Fonte:Lynch \& Hobbie, 1988

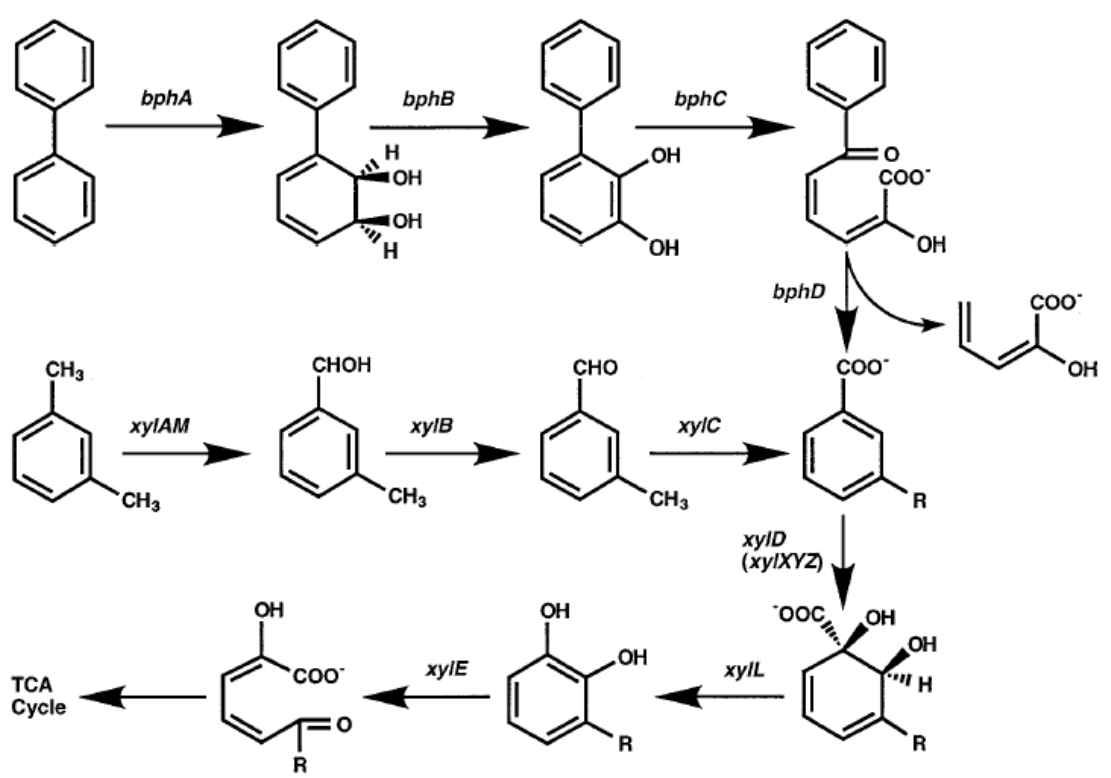

Figura 10: Via de degradação do bifenilo e do meta-xileno pela cepa Beijerinckia sp. B1. Os genes codificam para enzimas responsáveis por cada passo da degradação, indicado cada gene uma enzima específica: $b p h \mathrm{~A}$-bifenilo dioxigenase; $b p h \mathrm{~B}$ - cis-2,3-dihidro-2,3dihidroxibifenilo desidrogenase; $b p h \mathrm{C}-2,3$ - dihidroxibifenilo 1,2-dioxigenase; $b p h \mathrm{D}$ - 2hidroxi-6-oxo-6-fenilexa-2,4-dienoato hidrolase; xlyAM - xileno monoxigenase; $x l y \mathrm{~B}$ benzilaloalcool desidrogenase; $x y l \mathrm{C}$-benzilaldeído desidrogenase; $x y l \mathrm{D}(\mathrm{XYZ})$ toluato dioxigenase; $x y l$ L- 1,2-dihidroxi-3-metilciclohexa-3,5-dieno-carboxilato desidrogenase; e $x y l \mathrm{E}$ - catecol 2,3-dioxigenase. No caso do bifenilo o radical -R é um hidrogênio e para o m-xileno o radical -R é um grupo metila. TCA corresponde ao ácido tricarboxila (Kim \& Zylstra, 1995). 
Contudo, não somente os genes presentes nos plasmídios são responsáveis pelas vias de degradação de compostos xenobióticos, mas há também os genes presentes no genomas bacterianos. Um exemplo são os genes de degradação para o tolueno, como dito anteriormente, os genes $x y l$, presentes no plasmídio TOL, é um dos responsáveis por uma das vias de degradação do tolueno, contudo, há outros genes catabólicos presentes em cromossomos bactérianos que também degradam o tolueno, sendo o caso dos genes tod, encontrados na Pseudomonas putida F1, entre outros (Zylstra \& Gibson, 1991; Mosqueda \& Ramos, 2000). A organização deste gene, encontra-se na figura 11 .

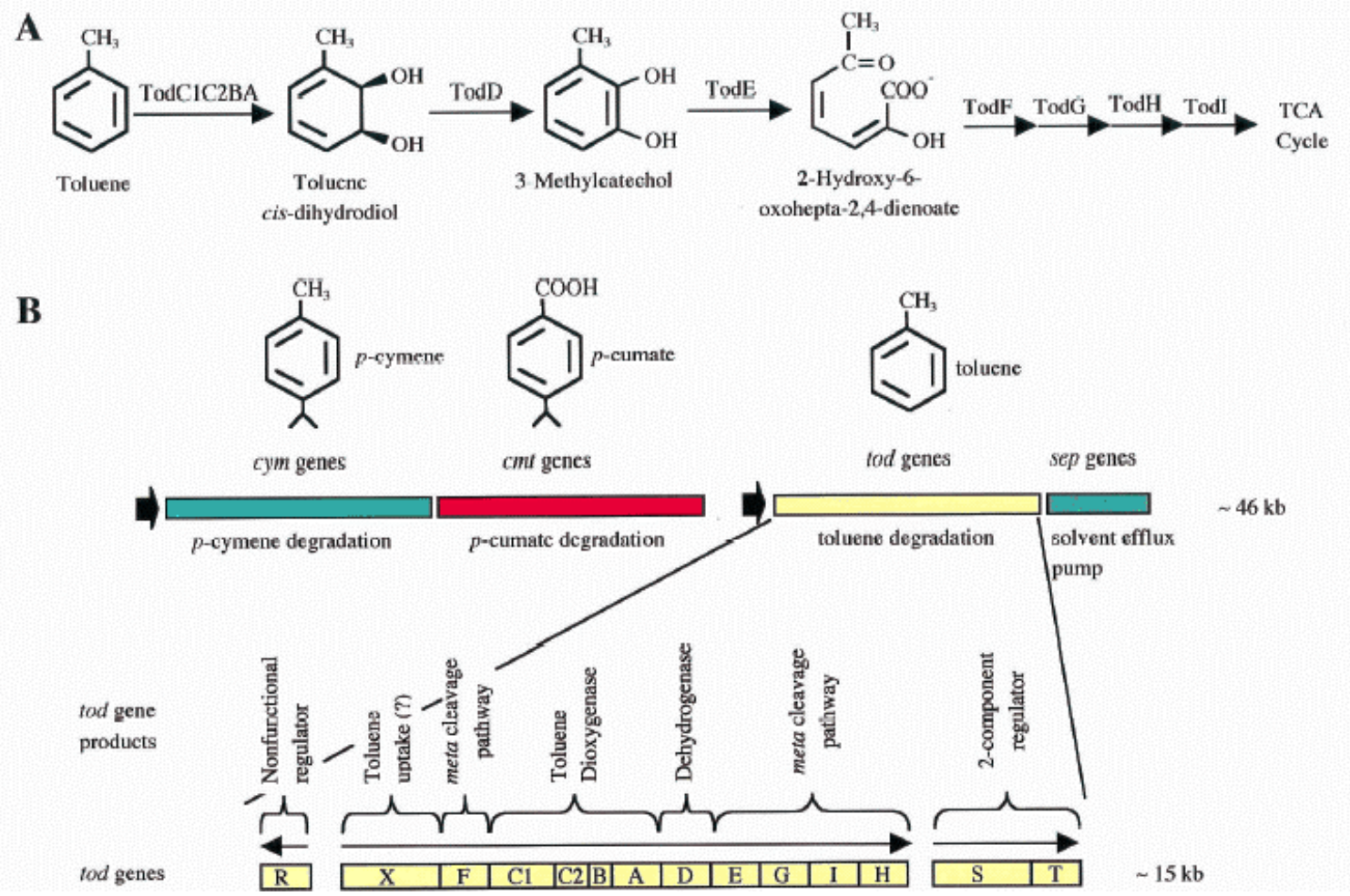

Figura 11: (A) Via de degradação do tolueno na P. putida F1. Produtos dos genes catalizando cada passo. (B) Organização genética dos genes de degradação do tolueno e genes que vizinhos na $P$. putida F1 (Parales et al. 2000). 
Muitas vezes, entre os genes plasmidiais e cromossomais ocorrem interações que geram a expressão do fenótipo catabólico. Isto se deve porque, muitos plasmídios carregam genes que codificam para vias incompletas de degradação, neste caso, para que o microrganismo possa utilizar um determinado composto xenobiótico como única fonte de carbono e energia, os genes cromossomais devem complementar os genes do plasmídio com genes que codificam para enzimas ligadas a vias metabólicas centrais de obtenção de energia (Lynchie \& Hobbie, 1988). Isto ocorre com os genes $t f d$, que estão localizados no plasmídio pJP4 da Ralstonia eutropha JMP132 e codificam para a via de degradação do ácido 2,4- dichlorophenoxyacético (Laemmli et al., 2000), até o composto 3-oxoadipato. Segundo Vedler et al. (2000); Laemmli, et al. (2000), este plasmídio possui 6 genes catabólicos: $t f d \mathrm{~A}, t f d \mathrm{~B}$ e $t f d \mathrm{CDEF}$. (Figura 12), regulados por 2 proteinas reguladoras idênticas do tipo Lys R, chamados de TfdR e TfdS. Inicialmente, acreditava-se que o Tfd T também codificasse para uma proteína reguladora, mas foi descoberto que este não era funcional devido a uma deleção na região C-terminal, causada pela inserção de uma seqüência IS (seqüência de inserção) (Laemmli et al., 2000).

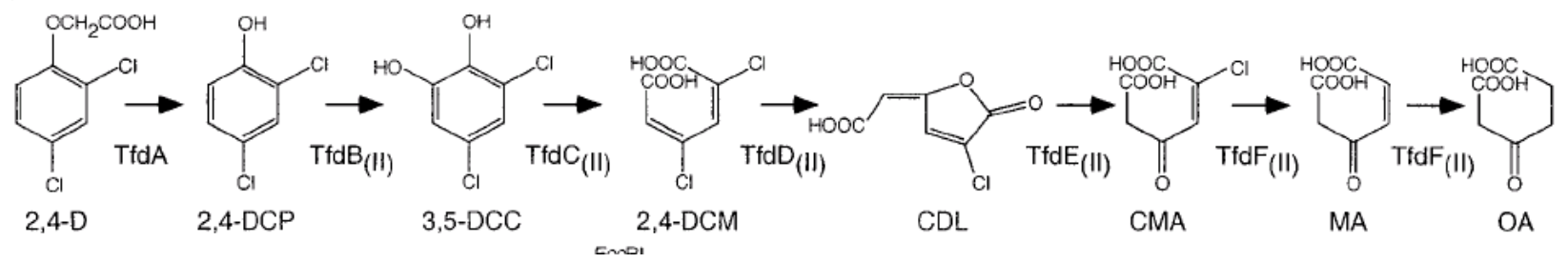

Figura 12: Passos da degradação do ácido 2,4- dichlorophenoxyacético (2,4-D). Catálize das enzimas sintétizadas por cada gene $t f d$ : $t f d \mathrm{~A}-2,4-\mathrm{D} \alpha$-keloglutarato dioxigenase; $t f d \mathrm{~B}_{(\mathrm{II})}$ - clorofenol hidroxilase; $t f d \mathrm{C}_{(\mathrm{II})}$ - clorocatecol 1,2- dioxigenase; $t f d \mathrm{D}_{(\mathrm{II})}$ - cloromuconato cicloisomerase; $t f d \mathrm{E}$ (II) - dienolactona hidrolase; $t f d \mathrm{~F}_{(\mathrm{II})}{ }^{-}$(cloro)maleilactato redutase (Laemmli et al., 2000). 
Além dos plasmídios citados anteriormente, existem outros plasmídios que codificam para vias catabólicas de xenobióticos. Os plasmídios de maior interesse para o presente estudo são o OCT e o NAH, associados ao catabolismo dos alcanos e do naftaleno respectivamente. Os genes catabólicos do plasmídio NAH, são organizados em dois operons, um que está relacionado com a trasformação do naftaleno a salicilato (operon nahAaAbAcAdBFCED) e outro responsável pela transformação do salicilato a intermediários do ciclo do ácido tricarboxílico (piruvato e acetil coenzima A) através da via de meta-clivagem (nah GTHINLOMKJ) (figura 13). A regulação dos dois operons é mediada por uma única proteína, NahR, que atua como um regulador positivo para ambos os promotores, com o salicilato sendo o indutor do sistema (Ferrero et al., 2002).

Também, na via de degradação do naftaleno, foi descrito o gene nod $\mathrm{B}$ que codifica para a naftaleno dioxigenase, a primeira enzima na via de degradação do naftaleno da $P$. putida ATCC 17484 (Kurkela et al. 1988).

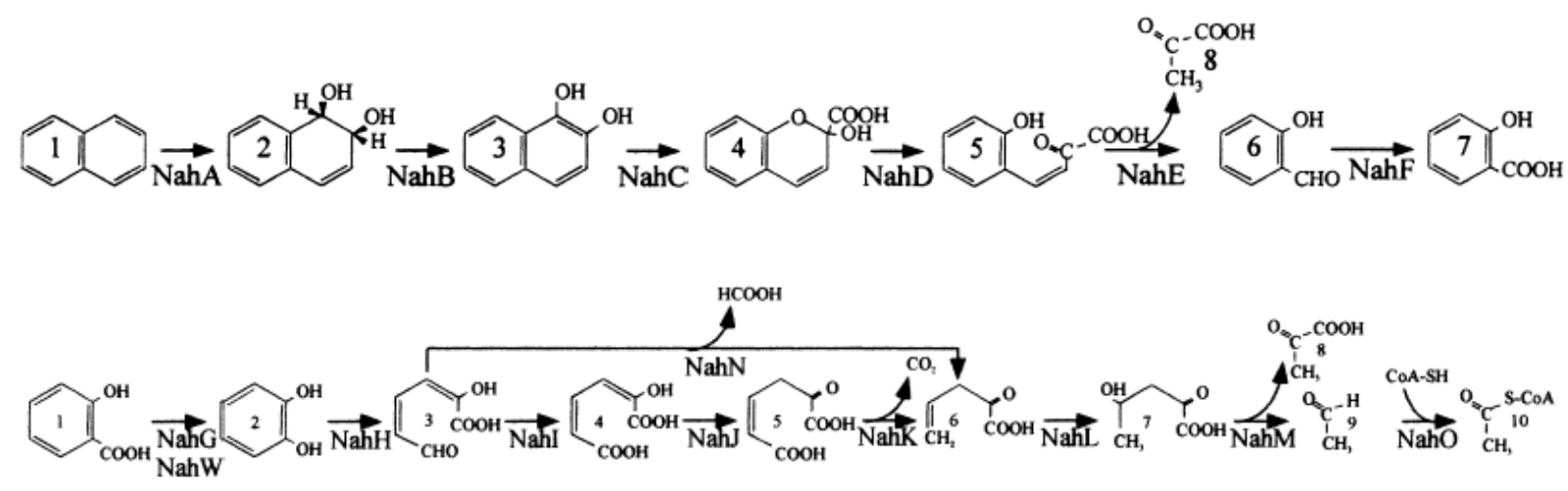

Figura 13: Organização bioquímica e genética do gene nah no cromossomo da $P$. stutzeri AN10 que codifica para a biotransformação do naftaleno para acetil coenzima A. Cada gene codifica para uma enzima específica: nahA- naftaleno 1,2-dioxigenase ou $n a h \mathrm{~W}$ salicilato hidroxilase; nahB - 1,2-dihidroxi-1,2- dihidronaftaleno desidrogenase; nahC 1,2-dihidroxi-naftaleno dioxigenase; nahD- 2-hidroxicromeno-2-carboxilato isomerase; nahE- tHBPA hidratase-aldolase; nahF- salicilaldeído desidrogenase; nahG- salicilato hidroxilase; $n a h \mathrm{H}$ - catecol 2,3-dioxigenase; nahI- semialdeído hidroximucônico desidrogenase; nahJ- 4-oxalocrotonato isomerase; nahK- 4-oxalocrotonato descarboxilase; $n a h \mathrm{~L}$ - 2-oxopenta-4-enoato hidratase; nahM- 2-oxo-4-hidroxipentanoato aldolase; nahOacetaldeído desidrogenase e $n a h \mathrm{~N}$ semialdeído hidroximocônico hidrolase (Bosch et al., 1999; Bosch et al., 2000) 
No caso do plasmídio OCT, que codifica para proteínas envolvidas na utilização de nalcanos, temos o exemplo do plasmídio OCT da Pseudomonas oleovorans onde foi observado 2 operons alkBFGHJKL and alkST que codificam para todas as proteínas necessárias para a degradação de alcanos lineares com 5- a 12-carbonos (Beilen et al., 1994). Neste mesmo plasmídio, verificou-se a presença do gene alkB codificando para alcano hidroxilase, uma monoxigenase que é a primeira enzima responsável pela via de degradação de alcanos de cadeias curtas na via de degradação da $P$. oleovorans (Kok et al., 1989).

Além disso, recentemente, foram encontrados e caracterizados múltiplos sistemas de alcano - hidroxilase em 2 linhagens de Rhodococcus (R. erythropolis NRRL B-16531 e Rhodococcus sp. Q15) isolados de localizações geográficas diferentes (Whyte et al., 2001b). Ambos microrganismos degradadores de alcanos que contém pelo menos 4 alcanos monoxigenases homólogos ( $\mathrm{Rh}$ alkB1, $\mathrm{Rh}$ alkB2, Rh alkB3 e Rh alkB4) diferentes (Whyte et al., 2001b). De acordo com Whyte et al. (1996, 1998, 1999b) os genes de Rhodococcus sp. Q15 codificam monoxigenases que mineralizam alcanos de cadeia longa, como hexadecano $\left(\mathrm{C}_{16}\right)$ e octacosano $\left(\mathrm{C}_{28}\right)$ ou mesmo compostos com maior número de átomos de carbono.

Estudos com a Pseudomonas putida GPo1 mostraram que esta cepa é capaz de oxidar alcanos C5 a C12 para 1-alcanóis, permitindo desta forma que ocorra o crescimento bacteriano. Segundo Smits et al. (2002) o sistema de alcano hidroxilase consiste de 3 componentes: a alcano hidroxilase (alkB), rubredoxina (alk $\mathrm{G})$ e a redutase rubroxina (alk $\mathrm{T})$. O alkB codifica para proteínas de membrana integral férricas não- heme que proporciona uma reação de hidroxilação. A rubredoxina por sua vez, transfere elétrons da rubredoxina redutase flavoproteína NADH-dependente para a alcano hidroxilase. Genes relacionados ao gene alcano hidroxilase (alkB) da GPo1 foram detectados em uma grande fração de populações microbianas em ambientes contaminados com óleo (Smits, et al., 2002). A representação da organização de alguns genes alk em diferentes organismos se encontra na figura 14. 


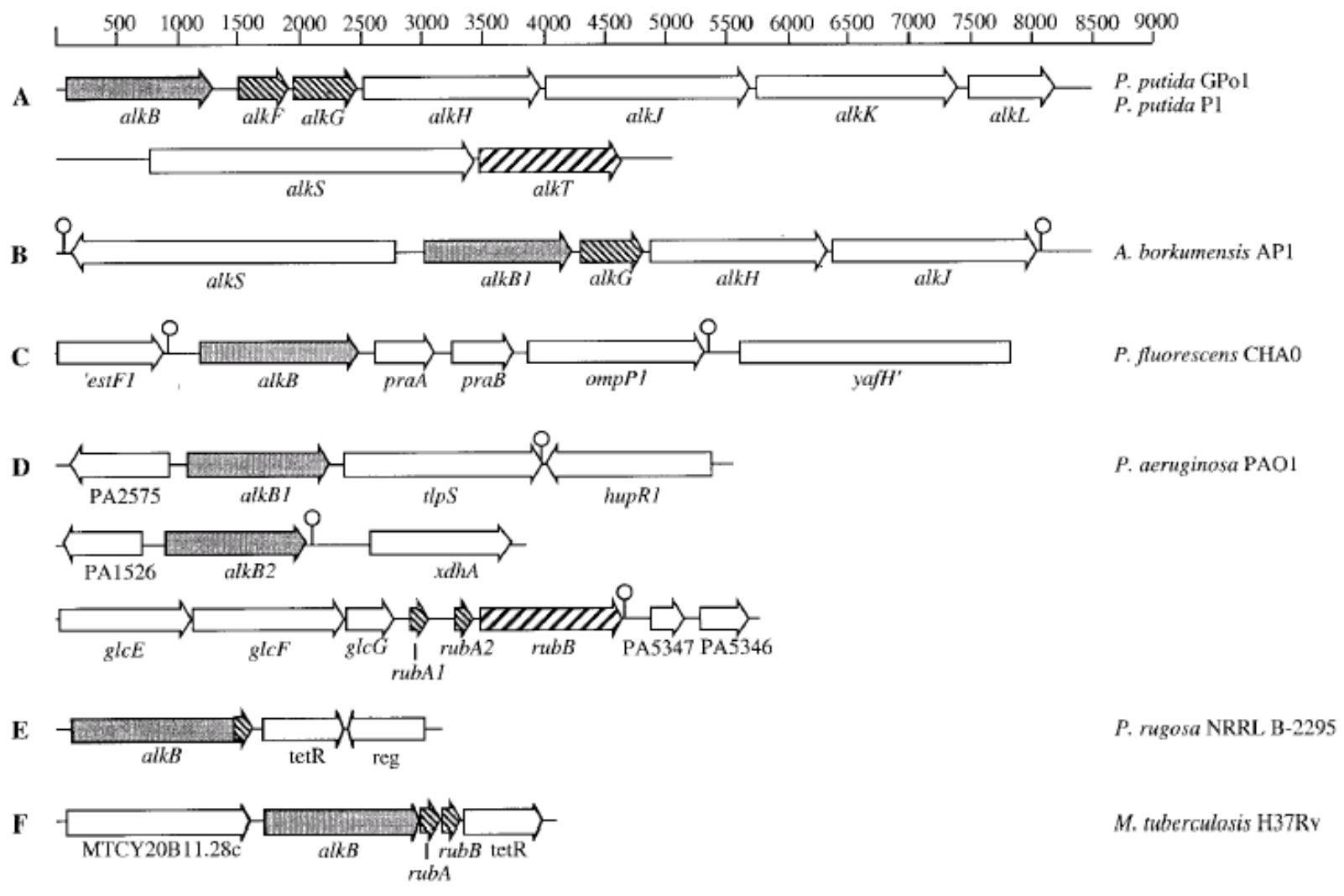

Figura 14: Organização dos genes alk em diferentes microrganismos. Os genes que codificam para as enzimas alcano hidroxilases estão indicados em cinza, os genes da rubredoxina e rubredoxina redutase estão indicados em hachurado fino e grosso respectivamente. (A) Representação dos genes das Pseudomonas GPo1 e P. putida P1: alk $\mathrm{B}$ - alcano hidroxilase; alkF-rubedoxina 1; alk $\mathrm{G}$ - rubredoxina 2; alk $\mathrm{H}$ - aldeído desidrogenase; alkJ - alcóol desidrogenase; alkK- acil coenzima A sintetase; alkL- proteína de membrana externa; alkS- proteína regulatória; alkT, rubredoxina redutase. (B) $A$. borkumensis AP1: alkS - proteína regulatória putativa; alkB1- alcano hidroxilase; alkGrubredoxina; alkH- aldeído desidrogenase putativa; alkJ - alcóol desidrogenase putativa. (C) P. fluorescens $\mathrm{CHA} 0$, 'est $\mathrm{F} 1$-esterase; alkB- alcano hidroxilase; praA e praBproteínas ativadoras da oxidação do alcano; omp $\mathrm{P} 1$ - proteína de membrana externa; $y a f \mathrm{H}$ 'acil CoA desidrogenase. (D) P. aeruginosa PAO1. PA2575-proteína hipotética; alkB1alcano hidroxilase; $t l p \mathrm{~S}$ - proteína de quimiotaxia aceptora de metilas; hupR1- proteína regulatória da retirada de hidrogênio; PA 1526- proteína regulatória da família GntR; alkB2- alcano hidroxilase 2; $x d h \mathrm{~A}$, homólogo da xantina desidrogenase; glc EFG- proteínas hipotéticas; (E) P. rugosa NRRL B-2295: alkB- alcano hidroxilase; tetR- proteína regulatória putativada família da TetR; reg - proteína regulatória putativa. (F) $M$. tuberculosis H37Rv: MTCY20B11.28c- transportador catiônico; alkB- alcano hidroxilase; rubA - rubredoxina $1 ; r u b \mathrm{~B}$ - rubredoxina 2 ; tetR- proteína reguladora putativa da família TetR (Smits et al. 2002). 
O fato de genes, de muitas vias de degradação, se encontrarem em plasmídios e/ou em elementos genéticos móveis, podem influenciar nas mudanças genéticas de uma comunidade microbiana durante a adaptação a ambientes contaminados, visto que a transferência horizontal de genes catabólicos responsáveis pela biodegradação de poluentes, pode ser um dos mecanismos para a evolução de populações bacterianas e a adaptação dessas comunidades à ambientes contaminados (Werlen et al., 1996; Herrick et al., 1997). Segundo Whyte et al. (1997), os plasmídios conjugativos podem ser transferidos lateralmente para outras bactérias, expandindo assim, o potencial metabólico para outros membros de um ecossistema sendo portanto agentes importantes nas trocas genéticas entre as bactérias.

Leahy \& Colwell (1990) relataram evidências sobre o papel dos plasmídios na adaptação a hidrocarbonetos, onde, foram observadas uma maior freqüência e multiplicidade de plasmídios nas bactérias isoladas de ambientes contaminados, do que nas bactérias isoladas de ambientes pristinos.

Além disso, Poelarends et al. (2000) verificaram que cepas isoladas filogenéticamente distintas de ambientes contaminados e capazes de degradar haloalcanos apresentavam o gene altamente conservado da haloalcano desalogenase (dhaA), sugerindo que tenha ocorrido transferência horizontal do gene nestas cepas. No trabalho de Stuart-Keil et al. (1998), também foi observado a transferência do gene nahAc em cepas filogeneticamente distintas em um local altamente contaminado, sugerindo que a persistência do plasmídio catabólico para naftaleno teve um papel fundamental na adaptação da comunidade microbiana no local do estudo.

\subsubsection{Biodiversidade de microrganismos degradadores de hidrocarbonetos}

A capacidade de degradar hidrocarbonetos do petróleo é apresentada por diversos microrganismos, principalmente fungos e bactérias. Apesar da ubiqüidade destes organismos nos ecossistemas terrestres (Atlas et al., 1980; Jones \& Edington, 1968) e aquáticos (Buckley et al., 1976; Mulkins-Phillips \& Stewart, 1974; Ward \& Brock, 1976), o número total de comunidades heterotróficas representadas por bactérias e fungos capazes de degradar hidrocarbonetos é altamente variável, trabalhos que discutem as faixas de 
ocorrências destes microrganismos mostram que a quantidade de fungos no solo pode variar de 6\% (Jones et al., 1970) a 82\% (Pinholt et al., 1979) e para bactérias no solo de 0,13\% (Jones et al., 1970) a 50\% (Pinholt et al., 1979). Enquanto que em ambientes marinhos, a quantidade de bactérias capazes de utilizar hidrocarbonetos pode variar de 0,003\% (Hollaway, 1980) a 100\% (Mulkins-Phillips \& Stewart, 1974). O estudo de microrganismos em cultura pura demonstram que, em geral, estes isolados podem metabolizar somente alguns tipos de hidrocarbonetos (Britton, 1984), entretanto, para que se ocorra a degradação de misturas complexas, como o óleo bruto, nos ambientes terrestres (Bossert \& Bartha, 1984), de água doce (Cooney, 1984) e marinho (Atlas, 1981; Floodgate, 1984) é necessária a presença de consórcios com diferentes capacidades enzimáticas. Desta forma pode-se concluir que o sinergismo é um mecanismo importante utilizado pelas comunidades microbianas.

A habilidade de degradar e/ou utilizar hidrocarbonetos como substratos é observado em grande variedade de gêneros de bactérias e fungos. Floodgate (1984), listou 25 gêneros de bactérias degradadoras de hidrocarbonetos e 27 gêneros de fungos que foram isolados de ambiente marinho. Uma similar compilação de dados foi realizada por Bossert \& Bartha (1984) para isolados de solo incluindo 22 gêneros de bactérias e 31 gêneros de fungos. Baseando-se nos números de trabalhos publicados, as bactérias degradadoras mais significativas, tanto no solos como em ambientes marinhos, são pertencentes aos gêneros Achromobacter, Acinetobacter, Alcaligenes, Arthrobacter, Bacillus, Flavobacterium, Nocardia e Pseudomonas spp. e os corineformes (Leahy \& Colwell, 1990). Contudo, alguns gêneros são predominantes de ambientes marinhos, devido as condições do ambiente como salinidade, $\mathrm{pH}$ e concentração, tipo e disponibilidade de nutrientes necessárias para a sobrevivência destes organismos, como é o caso do gênero Vibrio spp. que está limitado ao ambiente marinho devido a salinidade (Leahy \& Colwell, 1990). Segundo Austin et al. (1977), estudos quantitativos de grupos taxonômicos de bactérias degradadoras de petróleo nas águas e sedimento da Baía de Chesapeake (Maryland - EUA), mostraram que tanto os gêneros Pseudomonas, Micrococcus e Nocardia spp., como membros da família Enterobacteriaceae, actinomicetos e corineformes, constituíam 95\% dos isolados obtidos. 
Nos isolados marinhos, os fungos mais freqüentemente encontrados foram: Aureobasidium, Candida, Rhodotorula e Sporobolomyces spp.; e nos isolados encontrados no solo observou-se abundância de Trichoderma e Mortierella spp. No caso do Aspergillus e Penicillium spp., esses têm sido freqüentemente isolados em ambos os ambientes. Segundo, Kirk \& Grodon (1988), devem-se somar aos gêneros adaptados ao ambiente marinhos, Corollospora, Dendryphiella, Lulworthia e Varicosporina.

Segundo Walker et al. (1976) também já foi possível isolar a alga Prototheca zopfi capaz de utilizar óleo bruto, degradando n-alcanos e isoalcanos, bem como alguns hidrocarbonetos aromáticos. Cerniglia et al. (1980) e Cerniglia \& Gibson (1979) relataram que fungos, Cunninghamella elegans e gêneros de cianobactérias, algas verdes, vermelhas, marrons e diatomáceas, são capazes de degradar compostos aromáticos como naftaleno e em alguns casos até mesmo o bifenilo.

Portanto, os hidrocarbonetos podem ser metabolizados por muitos gêneros de bactérias, fungos filamentosos, leveduras e até mesmo por algas unicelulares (Morgan \& Watkinson, 1994). Com isto, a elucidação das condições em que a comunidade microbiana e sua diversidade é desenvolvida e mantida nos diversos ambientes, assim como o conhecimento da diversidade da comunidade, poderá auxiliar nos processos de biorremediação de maneira a estimular e acelerar a biodegradação dos ambientes impactados com hidrocarbonetos (Pritchard et al., 1996).

Além disso, vêm sendo utilizadas em estudos de monitoramento de populações microbianas naturais ou introduzidas no ambiente e para estudos de ecologia, técnicas de biologia molecular involvendo métodos de extração direta de DNA a partir das amostras ambientais e reação de amplificação em cadeia pela polimerase (PCR) com a utilização de iniciadores adequados para a detecção específica de genes ou de microrganismos, além da técnica de Eletroforese em Gel com Gradiente de Agentes Desnaturantes (DGGE) e do seqüenciamento genético. Estas técnicas permitem a análise da diversidade taxonômica e genética, do perfil de comunidades microbianas e também da dispersão de genes funcionais específicos no ambiente, superando as limitações impostas pelos métodos clássicos de isolamento e cultivo (Amann et al., 1995; Torsvik et al., 1998). Estas novas estratégias têm permitido o estudo de microrganismos não cultiváveis, os quais representam mais de 99\% 
dos microrganismos que ocorrem naturalmente no ambiente, bem como o estudo de grupos de microrganismos específicos em amostras ambientais (Gelsomino et al., 1999).

Na última década, uma variedade de protocolos baseados na utilização de PCR para detecção de microrganismos em amostras de solo e sedimento têm sido relatada (Smalla et al., 1993; Hammann et al., 1999). A combinação das técnicas de PCR e DGGE, têm aumentado significativamente a sensibilidade da detecção de microrganismos em amostras ambientais. Dessa forma, a aplicação destas técnicas vêm permitindo o conhecimento de comunidades e de suas diversidades microbianas de interesse ambiental através da caracterização genotípica.

\subsection{Bifenilos Policlorados (PCBs)}

\subsubsection{Definições e origens dos PCBs}

Os bifenilos policlorados (PCBs) são moléculas orgânicas produzidas comercialmente pela cloração direta da molécula de bifenilo usando cloreto férrico como catalisador. A molécula de bifenilo é constituída por dois anéis conectados com seis átomos de carbono cada, e a molécula de PCB é qualquer molécula que apresente múltiplos cloros

ligados ao núcleo de bifenilo (figura 15). As moléculas de cloro podem estar ligadas a qualquer um ou todos os dez sítios disponíveis, sendo teoricamente possível a formação de 209 diferentes compostos de PCBs (Bedard et al., 1987). A numeração correspondente a cada um deles, segue as regras da IUPAC (International Union of Pure and Applied Chemistry) para caracterização de substituintes em bifenilos. A tabela 4 apresenta a correlação entre o número do PCB e sua estrutura (Ballschmiter \& Zell, 1980).

Os isômeros individuais e homólogos são genericamente referidos como congêneres e estão representados na figura 16. A sua fórmula molecular é dada como $\mathrm{C}_{12} \mathrm{H}_{\mathrm{x}} \mathrm{Cl}_{\mathrm{y}}$, onde $\mathrm{x}$ $=0$ a 10 e $y=10-x$.

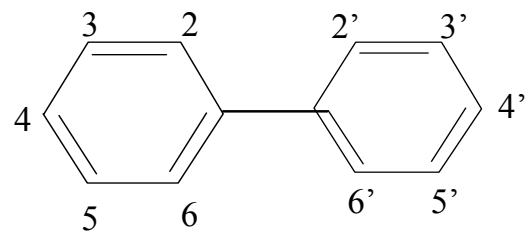

Figura 15: Estrutura molecular dos bifenilos policlorados (PCBs) 
Tabela 4. Sistema de numeração dos congêneres de PCBs

\begin{tabular}{|c|c|c|c|c|c|c|c|}
\hline$n^{8}$ & monociorobifenilos & $n^{\beta}$ & tetraclorobifenilos & $n^{8}$ & pentaclorobifenlios & $n^{9}$ & hexacloroblfenllos \\
\hline 1 & 2 & 52 & $2,2,5,5^{\prime}$ & 105 & $2,3,3^{\prime}, 4,4^{\prime}$ & 161 & $2,3,3,4,5,6$ \\
\hline $\begin{array}{l}2 \\
3\end{array}$ & $\begin{array}{c}3 \\
4 \\
\text { dicloroblfenllos }\end{array}$ & $\begin{array}{l}53 \\
54 \\
55\end{array}$ & $\begin{array}{l}2,2,5,6^{\prime} \\
2,2^{\prime}, 6,6^{\prime} \\
2,3,3^{\prime}, 4\end{array}$ & $\begin{array}{l}106 \\
107 \\
108\end{array}$ & $\begin{array}{l}2,3,3,4,5 \\
2,3,3^{\prime}, 4^{\prime}, 5 \\
2,3,3^{\prime}, 4,5^{\prime}\end{array}$ & $\begin{array}{l}162 \\
163 \\
164\end{array}$ & $\begin{array}{r}2,3,3,4,5,5 \\
2,3,3^{\prime}, 4^{\prime}, 5,6 \\
2,3,3,4,5,6\end{array}$ \\
\hline $\begin{array}{l}4 \\
5 \\
6 \\
7 \\
8 \\
9\end{array}$ & $\begin{array}{l}2,2 \\
2,3 \\
2,3 \\
2,4 \\
2,4 \\
2,5\end{array}$ & $\begin{array}{l}56 \\
56 \\
57 \\
58 \\
59 \\
60 \\
61\end{array}$ & $\begin{array}{l}2,3,3^{\prime}, 4^{\prime} \\
2,3,3,5 \\
2,3,3^{\prime}, 5^{\prime} \\
2,3,3,6 \\
2,3,4,4^{\prime} \\
2,3,4,5\end{array}$ & $\begin{array}{l}109 \\
109 \\
110 \\
111 \\
112 \\
113 \\
114\end{array}$ & $\begin{array}{l}2,3,3^{\prime}, 4,6 \\
2,3,3^{\prime}, 4^{\prime}, 6 \\
2,3,3^{\prime}, 5,5 \\
2,3,3^{\prime}, 5,6 \\
2,3,3^{\prime}, 5^{\prime}, 6 \\
2,3,4,4^{\prime}, 5\end{array}$ & $\begin{array}{l}104 \\
165 \\
166 \\
167 \\
168 \\
169\end{array}$ & $\begin{array}{c}2,3,3,5,5,6 \\
2,3,4,4 ;, 5,6 \\
2,3^{\prime}, 4,4 ;, 5,5 \\
2,3,4,4 ;, 5,6 \\
3,3^{\prime}, 4,4,5,5 \\
\text { heptaciorobifenilos } \\
\end{array}$ \\
\hline 10 & 2,6 & 62 & $2,3,4,6$ & 115 & $2,3,4,4,6$ & 170 & $2,2,3,3,4,4,5$ \\
\hline 11 & $3,3^{\prime}$ & 63 & $2,3,4,5$ & 116 & $2,3,4,5,6$ & 171 & $2,2,3,3,4,4,6$ \\
\hline 12 & 3,4 & 64 & $2,3,4,6$ & 117 & $2,3,4,5,6$ & 172 & $2,2^{\prime}, 3,3,4,5,5^{\prime}$ \\
\hline 13 & $3,4^{\prime}$ & 65 & $2,3,5,6$ & 118 & $2,3,4,4,5$ & 173 & $2,2,3,3,4,5,6$ \\
\hline 14 & 3,5 & 66 & $2,3^{\prime}, 4,4^{\prime}$ & 119 & $2,3,4,4,6$ & 174 & $2,2^{\prime}, 3,3,4,5,6^{\prime}$ \\
\hline 15 & $\begin{array}{c}4,4 \\
\text { triclorobifenilos }\end{array}$ & $\begin{array}{l}67 \\
68\end{array}$ & $\begin{array}{l}2,3,4,5 \\
2,3^{\prime}, 4,5\end{array}$ & $\begin{array}{l}120 \\
121\end{array}$ & $\begin{array}{l}2,3^{\prime}, 4,5,5^{\prime} \\
2,3^{\prime}, 4,5^{\prime}, 6\end{array}$ & $\begin{array}{l}175 \\
176\end{array}$ & $\begin{array}{l}2,2^{\prime}, 3,3,4,5,6 \\
2,2^{\prime}, 3,3,4,6,6^{\prime}\end{array}$ \\
\hline 16 & $2,2,3$ & 69 & $2,3,4,6$ & 122 & $2,3,3,4,5$ & 177 & $2,2,3,3,4,5,6$ \\
\hline 17 & $2,2,4$ & 70 & $2,3^{\prime}, 4^{\prime}, 5$ & 123 & $2,3,4,4^{\prime}, 5$ & 178 & $2,2,3,3,5,5,6$ \\
\hline 18 & $2,2,5$ & 71 & $2,3,4,6$ & 124 & $2,3,4,5,5^{\prime}$ & 179 & $2,2,3,3,5,6,6$ \\
\hline 19 & $2,2,6$ & 72 & $2,3^{\prime}, 5,5^{\prime}$ & 125 & $2,3,4,5,6^{\prime}$ & 180 & $2,2,3,4,4^{\prime}, 5,5^{\prime}$ \\
\hline 20 & $2,3,3$ & 73 & $2,3^{\prime}, 5^{\prime}, 6$ & 126 & $3,3,4,4,5$ & 181 & $2,2,3,4,4,5,6$ \\
\hline 21 & $2,3,4$ & 74 & $2,4,4,5$ & 127 & $3,3,4,5,5^{\prime}$ & 182 & $2,2^{\prime}, 3,4,4^{\prime}, 5,6^{\prime}$ \\
\hline 22 & $2,3,4$ & 75 & $2,4,4,6$ & & hexaclorobifenllos & 183 & $2,2,3,4,4,5,6$ \\
\hline 23 & $2,3,5$ & 76 & $2,3,4,5$ & 128 & $2,2^{\prime}, 3,3^{\prime}, 4,4^{\prime}$ & 184 & $2,2^{\prime}, 3,4,4^{\prime}, 6,6^{\prime}$ \\
\hline 24 & $2,3,6$ & 77 & $3,3^{\prime}, 4,4^{\prime}$ & 129 & $2,2^{\prime}, 3,3,4,5$ & 185 & $2,2 ', 3,4,5,5^{\prime}, 6$ \\
\hline 25 & $2,3,4$ & 78 & $3,3,4,5$ & 130 & $2,2^{\prime}, 3,3^{\prime}, 4,5^{\prime}$ & 186 & $2,2,3,4,5,6,6^{\prime}$ \\
\hline 26 & $2,3,5$ & 79 & $3,3^{\prime}, 5,5$ & 131 & $2,2,3,3,4,6$ & 187 & $2,2,3,4,5,5,6$ \\
\hline 27 & $2,3,6$ & 80 & $3,3^{\prime}, 5,5^{\prime}$ & 132 & $2,2^{\prime}, 3,3^{\prime}, 4,6^{\prime}$ & 188 & $2,2,3,4^{\prime}, 5,6,6^{\prime}$ \\
\hline 28 & $2,4,4$ & 81 & $3,4,4,5$ & 133 & $2,2^{\prime}, 3,3,5,5$ & 189 & $2,3,3,4,4,5,5$ \\
\hline 29 & $2,4,5$ & & pentaclorobifenilos & 134 & $2,2,3,3,5,6$ & 190 & $2,3,3,4,4,5,6$ \\
\hline 30 & $2,4,6$ & 82 & $2,2^{\prime}, 3,3^{\prime}, 4$ & 135 & $2,2^{\prime}, 3,3^{\prime}, 5,6^{\prime}$ & 191 & $2,3,3,4,4^{\prime}, 5^{\prime}, 6$ \\
\hline 31 & $2,4,5$ & 83 & $2,2,3,3,5$ & 136 & $2,2^{\prime}, 3,3^{\prime}, 6,6^{\prime}$ & 192 & $2,3,3^{\prime}, 4,5,5^{\prime}, 6$ \\
\hline 32 & $2,4,6$ & 84 & $2,2,3,3,6$ & 137 & $2,2,3,4,4,5$ & 193 & $2,3,3^{\prime}, 4^{\prime}, 5,5^{\prime}, 6$ \\
\hline 33 & $2,3,4$ & 85 & $2,2^{\prime}, 3,4,4^{\prime}$ & 138 & $2,2^{\prime}, 3,4,4^{\prime}, 5^{\prime}$ & & octacloroblfenllos \\
\hline 34 & $2,3,5$ & 86 & $2,2,3,4,5$ & 139 & $2,2^{\prime}, 3,4,4^{\prime}, 6$ & 194 & $2,2^{\prime}, 3,3,4,4^{\prime}, 5,5^{\prime}$ \\
\hline 35 & $3,3,4$ & 87 & $2,2,3,4,5^{\prime}$ & 140 & $2,2^{\prime}, 3,4,4^{\prime}, 6^{\prime}$ & 195 & $2,2,3,3,4,4,5,6$ \\
\hline 36 & $3,3,5$ & 88 & $2,2,3,4,6$ & 141 & $2,2^{\prime}, 3,4,5,5^{\prime}$ & 196 & $2,2^{\prime}, 3,3^{\prime}, 4,4^{\prime}, 5^{\prime}, 6$ \\
\hline 37 & $3,4,4^{\prime}$ & 89 & $2,2,3,4,6^{\prime}$ & 142 & $2,2,3,4,5,6$ & 197 & $2,2^{\prime}, 3,3^{\circ}, 4,4^{\prime}, 6,6^{\prime}$ \\
\hline 38 & $3,4,5$ & 90 & $2,2,3,4,5$ & 143 & $2,2,3,4,5,6$ & 198 & $2,2,3,3,4,5,5,6$ \\
\hline 39 & $\begin{array}{l}3,4,5 \\
\text { (1) }\end{array}$ & 91 & $2,2,3,4,6$ & 144 & $2,2,3,4,5,6$ & 199 & $2,2,3,3,4,5,6,6^{\prime}$ \\
\hline & $\frac{\text { tetraclorobifenilos }}{2,2^{\prime}, 3,3^{\prime}}$ & $\begin{array}{l}92 \\
93\end{array}$ & $2,2,3,5,5^{\prime}$ & 145 & $2,2 ', 3,4,6,6^{\prime}$ & 200 & $2,2^{\prime}, 3,3,4,5,6,6^{\prime}$ \\
\hline 41 & & $\begin{array}{l}93 \\
94\end{array}$ & $2,2,3,5,6$ & 146 & $2,2^{\prime}, 3,4,5,5{ }^{\prime}$ & $\begin{array}{l}201 \\
202\end{array}$ & $\begin{array}{l}2,2^{\prime}, 3,3^{\circ}, 4^{\prime}, 5,5^{\prime}, 6 \\
2,3,3^{\prime}, 5^{\prime}, 6,6^{\prime}\end{array}$ \\
\hline 42 & $2,2,3,4^{\prime}$ & 95 & $\begin{array}{l}2,2,3,5,6 \\
2,2,3,5,6\end{array}$ & $\begin{array}{l}147 \\
148\end{array}$ & $\begin{array}{l}2,2^{\prime}, 3,4^{\prime}, 5,6 \\
2,2^{\prime}, 3,4^{\prime}, 5,6^{\prime}\end{array}$ & 203 & $\begin{array}{l}2,2^{\prime}, 3,3,5,5,6,6^{\prime} \\
2,2^{\prime}, 3,4,4^{\prime}, 5,5^{\prime}, 6\end{array}$ \\
\hline 43 & $2,2,3,5$ & 96 & $2,2,3,6,6^{\prime}$ & 149 & 2, $2^{\prime}, 3,4^{\prime}, 5^{\prime}, 6$ & 204 & $2,2^{\prime}, 3,4,4^{\prime}, 5,6,6^{\prime}$ \\
\hline 44 & $2,2,3,5^{\prime}$ & 97 & $2,2,3,4,5$ & 150 & $2,2^{\prime}, 3,4^{\prime}, 6,6^{\prime}$ & 205 & $2,3,3,4,4,5,5,6$ \\
\hline 45 & $2,2,3,6$ & 98 & $2,2,3,4,6$ & 151 & $2,2,3,5,5,6$ & & nonaclorobifenilos \\
\hline 46 & $2,2,3,6$ & 99 & $2,2,4,4,5$ & 152 & $2,2,3,5,6,6^{\prime}$ & 206 & $2,2^{\prime}, 3,3,4,4,5,5,6$ \\
\hline 47 & $2,2^{\prime}, 4,4^{\prime}$ & 100 & $2,2^{\prime}, 4,4^{\prime}, 6$ & 153 & $2,2^{\prime}, 4,4^{\prime}, 5,5^{\prime}$ & 207 & $2,2^{\prime}, 3,3^{\prime}, 4,4^{\prime}, 5,6,6^{\prime}$ \\
\hline 48 & $2,2,4,5$ & 101 & $2,2^{\prime}, 4,5,5^{\prime}$ & 154 & $2,2^{\prime}, 4,4^{\prime}, 5,6^{\prime}$ & 208 & $2,2^{\prime}, 3,3,4,5,5,6,6^{\prime}$ \\
\hline 49 & $2,2^{\prime}, 4,5^{\prime}$ & 102 & $2,2^{\prime}, 4,5,6^{\prime}$ & 155 & $2,2^{\prime}, 4,4^{\prime}, 6,6^{\prime}$ & & decaclorobifenil \\
\hline 50 & $2,2,4,6$ & 103 & $2,2^{\prime}, 4,5 ', 6$ & 156 & $2,3,3^{\prime}, 4,4^{\prime}, 5$ & 209 & $2,2^{\prime}, 3,3^{\prime}, 4,4^{\prime}, 5,5^{\prime}, 6,6^{\prime}$ \\
\hline 51 & $2,2^{\prime}, 4,6^{\prime}$ & 104 & $2,2^{\prime}, 4,6,6^{\prime}$ & 157 & $2,3,3,4,4^{\prime}, 5^{\prime}$ & & \\
\hline & & & & $\begin{array}{l}158 \\
159\end{array}$ & $\begin{array}{l}2,3,3^{\prime}, 4,4^{\prime}, 6 \\
2,3,3^{\prime}, 4,5,5^{\prime}\end{array}$ & & \\
\hline & & & & 160 & $2,3,3,4,5,6$ & & \\
\hline
\end{tabular}

Fonte: Ballschmiter \& Zell (1980) 


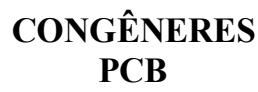

18

52

44

101

118

163

138

187

128

180
ESTRUTURA MOLECULAR
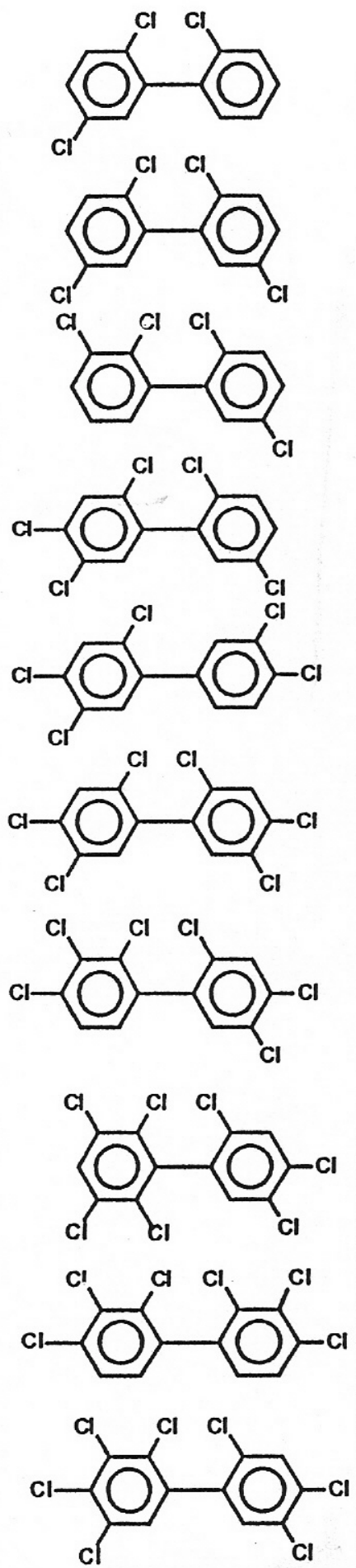

Figura 16: Estrutura de alguns congêneres de PCBs (Taniguchi, 1995). 
Os PCBs começaram a ser sintetizados no final do século XIX, mas só em 1929 é que passaram a ser produzidos comercialmente (Tanabe, 1988) quando foram manufaturados e vendidos como misturas complexas diferindo apenas em sua composição de cloro. Suas misturas cruas resultantes da cloração foram fracionadamente destiladas para produzir misturas comerciais de acordo com as propriedades desejadas. Seus produtos finais são desde óleos fluidos leves (di-, tri, e tetraclorobifenilo), óleos pesados e de alta densidade (pentaclorobifenilo) até graxas e ceras de alta composição de cloro (Abramowicz, 1990).

Podemos encontrar compostos de PCBs comercializados com diferentes nomes: Aroclor (Monsanto, EUA), Phenclor e Pyralene (Prodelec S.A., França), Clophen (Farbenfabriken Bayer, Alemanha) e Kanechlor (Kanegafuchi Chemical Industrial Co., Japão). O nome comercial muitas vezes também indica a composição do produto, como por exemplo, Aroclor 1242 (12 átomos de carbono e 42\% de cloro por peso que corresponde, em média, a três cloros por bifenilo) ( Hutzinger et al, 1974). O produto comercial "Askarel" é uma mistura sintética de PCBs (50-70\%) e triclorobenzenos (30-50\%) e foi o principal fluido dielétrico empregado em transformadores por muitos anos (Manahan, 1993).

Devido às suas vantajosas propriedades físicas e químicas, o PCB foi usado em grande escala no passado. As principais propriedades físicas deste composto são excelentes propriedades dielétricas, fluidez, baixa solubilidade em água e baixa pressão de vapor. As propriedades químicas incluem estabilidade térmica, estabilidade para oxidação, resistência ao ataque de ácidos, bases e produtos químicos corrosivos. Por apresentar todas essas propriedades térmicas e químicas, este produto acabou sendo empregado como plastificante, retardante de chama, lubrificante, fluido hidráulico, fluido isolante de capacitores e transformadores, isolante de fios elétricos, diluente orgânico, resina, tinta têxteis, em papel cópia sem carbono, transferente de calor, adesivo sintético e tinta do tipo epoxi (Lara, 1976; Sawhney, 1987; Yadav et alli, 1995).

Em um período de aproximadamente cinqüenta anos, dezoito milhões e seiscentas mil toneladas de PCBs foram produzidas. A intensa aplicação destes componentes química e termicamente estáveis resultaram em contaminação disseminada. A partir de 1966 a disseminação dos bifenilos policlorados tornou-se uma questão de grande interesse, pois 
foram encontrados em diversos compartimentos como ar atmosférico, águas de resíduos industriais e urbanos, plâncton, sedimentos aquáticos e tecidos adiposos humanos (Jensen, 1972).

A natureza lipofílica dos PCBs contribui para a sua tendência em se acumular nos depósitos de gordura, resultando em magnificação quando acumulado na cadeia alimentar (Rochkind-Dubinsky, 1987).

Por serem compostos voláteis e lipofilicos, os PCBs podem ser emitidos para a atmosfera e, dessa forma, originar um processo cíclico de contaminação do ar, água e sedimentos, bem como, sofrer acumulação na cadeia alimentar. Waid (1986, apud Boyle et al., 1992 ; Lauber, 1987) estimou que cerca de $10 \times 10^{7} \mathrm{Kg}$ de PCBs estão presentes na biosfera como contaminantes do solo, do ar e das águas, bem como, de plantas e animais.

Tanabe et al. (1983) constatou que 98\% dos PCBs liberados para o ambiente têm o oceano como destino final. Destes, apenas $4 \%$ permanecem na água do mar e na biota e os 96\% restantes localizam-se nos sedimentos. Estudos de laboratório realizados por Larsson et al. (1985) mostraram que produtos organoclorados não são imobilizados no processo de adsorção ao sedimento. Assim, os sedimentos podem atuar como fonte destes compostos para a coluna d'água e sua biota.

O ciclo ambiental do PCB pode ser visto na figura 17. Devido a dispersão ambiental deste poluente, até regiões não impactadas, como a Antártica, apresentam contaminação por PCBs na atmosfera, hidrosfera e comunidade biótica como peixes, algas e pingüins e várias aves (Lara et al., 1990; Montone, 1995). 


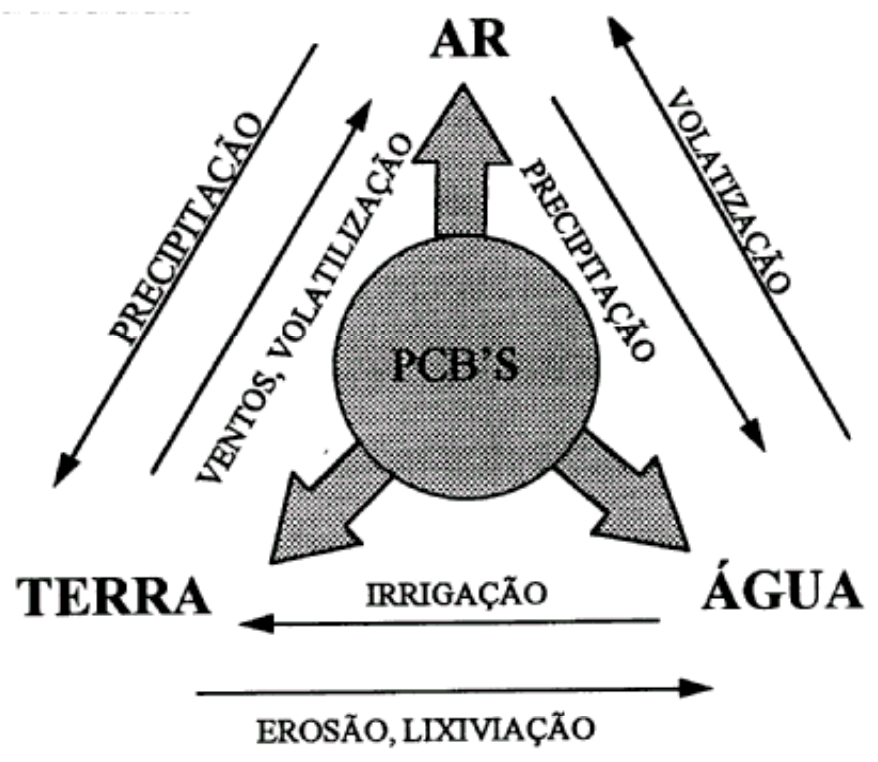

Figura 17: Ciclo Ambiental dos PCBs (Pellizari, 1995).

No Brasil, diversos autores já relataram a ocorrência de PCBs e hidrocarbonetos em sedimentos marinhos na região de Santos (Tommasi, 1985; Montone, 1987), bem como em organismos marinhos em Ubatuba e São Sebastião, no litoral paulista (Montone \& Weber, 1995) e na Baía de Todos os Santos, no litoral baiano (Tavares et al., 1988). Nogueira et al. (1987) constataram a presença de PCBs em tecidos adiposos humanos na população de São Paulo, comprovando a exposição da mesma a este poluente. Relatórios da Secretaria do Verde e do Meio Ambiente do Município de São Paulo (1995-1996) descrevem o estoque inadequado do óleo Askarel retirado de antigos transformadores, apresentando risco de contaminação ambiental.

$\mathrm{Na}$ região de Cubatão (SP) já foi relatada a presença de contaminação de solo e sedimento de áreas industriais por PCBs e outros organoclorados, inclusive, com casos de intoxicação humana (Helene, 1995). De maneira geral, a Baixada Santista está sujeita ao impacto causado pelas numerosas indústrias localizadas na região. Dentre elas, destacam-se a indústria petroquímica, de produção de fertilizantes, siderúrgica e de transformação de recursos naturais. Neste local, desembocam os cursos d'água que drenam as áreas industriais de Cubatão, o cais da COSIPA, da ULTRAFÉRTIL, do Porto de Santos e do Entreposto de Pesca. 
Os bifenilos policlorados podem ser degradados por processos de fotólise, de combustão e também de degradação microbiana

\subsubsection{Impactos dos PCBs no ambiente}

Os PCBs merecem uma atenção especial como poluentes ambientais por serem cancerígenos segundo comprovação do E.P.A. em 1996 (Phibbs, 1996) e por terem sidos produzidos e utilizados em grande escala por cerca de 50 anos.

Estudos sobre seus efeitos tóxicos relacionaram seu potencial de toxicidade com o grau de cloração. Também foi verificado que os congêneres de PCBs mais tóxicos contém de dois-para e ao menos dois-meta cloros, e que a adição de orto-cloro reduz seu efeito significantemente (Furukawa, 1987).

Os efeitos tóxicos dos PCBs têm sido detectados em diversos organismos. Em mamíferos observaram-se mal formações no fígado, enquanto que em aves, elas se dão no pericárdio e nos rins. Em alguns casos os PCBs também podem ser responsáveis por distúrbios no metabolismo de cálcio em certas espécies de aves, podendo desta forma afetar a espessura da casca dos ovos. No ambiente aquático estes produtos podem causar forte diminuição na ovulação de peixes de pequeno porte (WHO, 1976).

Em relação à presença de PCBs na população humana, sabe-se que geralmente ela é resultado de longa exposição aos mesmos. Vários estudos epidemiológicos clássicos de contaminação humana por PCBs são conhecidos, como o incidente ocorrido em Taiwan, em 1979, quando a ingestão de óleo de arroz contaminado afetou mais de duas mil pessoas (Jensen, 1972).

No Brasil, já ocorreu um acidente com Askarel que se encontrava estocado inadequadamente e moradores de uma favela do Rio de Janeiro utilizaram este como óleo de cozinha, ocorrendo desta forma, a intoxicação de diversas pessoas (Alves, 1996).

Porém, a exposição ocupacional tem sido a principal preocupação, apesar de terem sido detectadas concentrações acima de 1 ppm em 1/3 das amostras pesquisadas na população americana com nenhuma exposição ocupacional. O risco associado aos PCBs é a sua possível condição de cancerígeno, pois há relatos de que altos níveis de Aroclor 1260 podem causar câncer de pulmão em ratos (Kimbrough et al., 1990). 


\subsubsection{Degradação de $\mathrm{PCBs}$}

\subsubsection{Degradação fotoquímica e combustão}

Segundo Hooper et al., (1990), a degradação dos PCBs pode ser realizada por fotólise, combustão e degradação microbiana. Embora a fotólise tenha se mostrado um processo importante de detoxicação de alguns congêneres de PCBs, a maior parte dos PCBs liberados no ambiente, se acumulam nos sedimentos aquáticos ficando desta forma, protegidos da luz. Além disso, a degradação fotolítica requer ainda fótons com comprimento de onda da ordem de $280 \mathrm{~nm}$ e portanto, mais energéticos dos que chegam à atmosfera terrestre. A degradação fotolítica também contribui para a formação do composto tóxico dibenzofurano policlorado. Este composto e também as dioxinas são formadas no processo de combustão incompleta de PCBs. As temperaturas necessárias para a incineração completa são muito elevadas $\left(1200^{\circ} \mathrm{C}\right)$, o que torna o processo extremamente caro.

Na fotólise foi demonstrado que moléculas com maior número de átomos de cloro, são fotolizadas mais rapidamente do que as com menor número. O processo da fotorreação ocorre através da clivagem da ligação entre os átomos de carbono e de cloro, com a introdução de um átomo de hidrogênio na molécula de bifenilo (Roach, 1987).

\subsubsection{Bioquímica da biodegradação bacteriana de PCBs}

Visto os problemas da degradação fotoquímica e da combustão, é possível concluir que a degradação microbiana dos PCBs pode ser uma forma promissora de desintoxicação do ambiente.

A biodegradação aeróbia dos PCBs, geralmente, está limita a congêneres mais leves que possuem até 5 átomos de cloro na molécula de bifenilo (Bedard et al., 1987 a; Boyle et al., 1992). Segundo Hernandez et al.(1992), a degradação de PCBs se dá por cometabolismo e envolve a participação de pelo menos dois grupos de microrganismos para que se ocorra a mineralização completa da molécula. O primeiro grupo seria composto por 
microrganismos que cometabolizam PCBs até a formação clorobenzoato, o segundo grupo utilizariam este último composto, levando a mineralização.

Em geral, a via de degradação dos PCBs (figuras 18 e 19) é similar à de outros substratos aromáticos, como o tolueno e o naftaleno, envolvendo, a adição inicial de oxigênio na posição 2,3 do bifenilo pela ação da enzima bifenilo oxigenase e, em seguida, ocorre desidrogenação, originando catecol e clivagem do anel, gerando ácido clorobenzóico como produto final (Arensdof \& Focht, 1994). Além do ataque na posição 2,3 pela dioxigenase, foi relatado que a adição inicial de oxigênio também ocorre na posição 3,4 do anel benzênico em Alcaligenes eutrophus H850 (Bedard et al., 1987b) e na posição 5,6 do anel em Alcaligenes sp. JB1 (Commandeur et al., 1995).

Além disso, foi relatado que o crescimento prévio das cepas bacterianas com bifenilo, induz a atividade das enzimas envolvidas na degradação de PCBs (Bedard et al., 1986 ; Boop, 1986 ; Gibson et al. 1993), como foi observado em Acinetobacter e na Pseudomonas NCIB 10643 (Kohler et al., 1988).

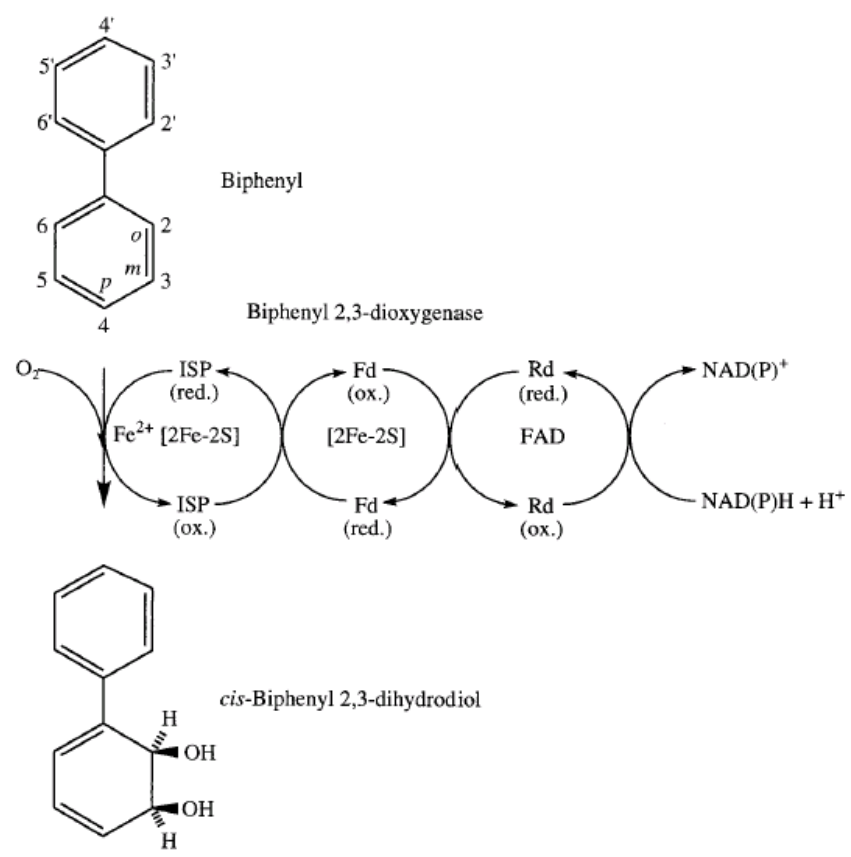

Figura 18: Reação catalizada pela bifenilo dioxigenase. Os átomos de carbonos numerados, correspondem às possíveis posições em que o cloro pode substituir o hidrogênio (não está representado) nos bifenilos clorados; $o, m$ e $p$ denotam as posições orto, meta e para respectivamente. Cofatores enzimáticos e centros redox estão representados para cada componente da proteína. Abreviações: ISP, proteína ferro-enxofre; Fd, ferrodoxina; Rd, redutase; ox, oxidado (Arnett et al., 2000). 


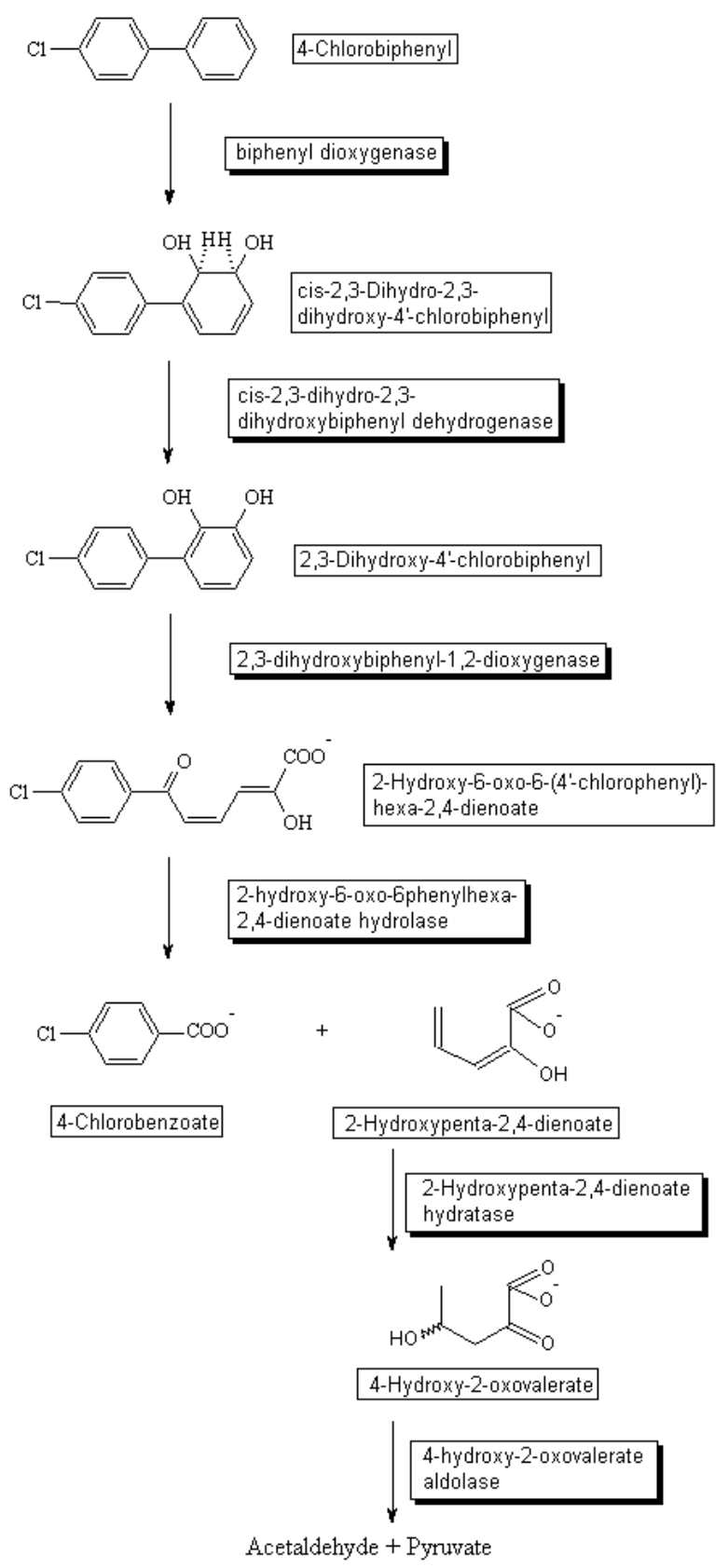

Figura 19: Via metabólica do 4- clorobifenilo pela Pseudomonas sp. strain LB400 (Chang $\&$ Oh, 2000)

A biodegradação anaeróbia dos PCBs ocorre via desalogenação redutiva. Vários padrões de desalogenação já foram descritos e ocorrem devido à atividade de diferentes populações de microrganismos degradadores que possuem afinidades específicas pelos 
congêneres de PCBs (Brown et al., 1984; Rochkind \& Dubinsky, 1987; Quensen et al., 1990).

A primeira descrição de desalogenação redutiva de PCBs foi observada em amostras de sedimento contaminadas com Aroclor 1242 no rio Hudson em Nova Iorque, nos Estados Unidos. Foi observado nessas amostras a remoção de átomos de cloro nas posições meta e para (Brown et al., 1984). Boyle et al (1992) também correlacionaram a redução da concentração de PCBs com a alteração das taxas de desalogenação e metanogênese.

A maior parte dos estudos de degradação anaeróbia de PCBs foram realizados com consórcios, devido a dificuldade no isolamento destes anaeróbios. Contudo, Ye et al. (1995), conseguiram obter uma cultura pura isolada de sedimento que foi capaz de degradar PCBs em anaerobiose.

Diversos autores (Boyle et al., 1993; Assaf-Anid et al., 1992; May et al., 1992; Bedard, 1990) acreditam que, em processo de degradação natural de PCBs com alto grau de cloração em congêneres de baixa toxicidade, seria realizado por microrganismos anaeróbios.

Portanto, tendo em vista que microrganismos aeróbios tendem a degradar compostos clorados leves e os anaeróbios compostos pesados, sistemas biorreatores de dupla fase (anaeróbio/aeróbio) têm sido desenvolvidos com a finalidade de se obter processos mais eficientes de biodegradação de PCBs.

\subsubsection{Genética da biodegradação de PCBs}

Assim como nos hidrocarbonetos, os plasmídios de microrganismos degradadores de PCBs também tem um papel muito importante no catabolismo deste composto. Foi demonstrado que um plasmídio encontrado em Klebsiella sp. codificava para a conversão de 4-clorobifenilo para ácido 4-clorobenzoato, assim como o plasmídio pKF1 encontrado em Acinetobacter sp. e Arthrobacter sp. também foi responsável pela degradação de bifenilos e bifenilos clorados em benzoatos e clorobenzoatos (Furukawa, 1987).

Contudo, Taira et al. (1992) clonaram e sequenciaram genes catabólicos de PCBs de Pseudomonas pseudoacaligenes KF 707, cepa degradadora de mono, di e tri-clorobifenilo, a partir de DNA cromossomal. Foi obtido um fragmento clonado, de 11,3 kb, contendo o operon bph $\mathrm{ABCXD}$, que codifica para enzimas que realizam a conversão de bifenilo e 
PCBs até ácido clorobenzóico. Na KF 707, os genes que codificam três das quatro enzimas responsáveis pela degradação de PCBs, estão localizados em um fragmento de 6,8 kb, denominado $b p h \mathrm{ABC}$. A região do $b p h \mathrm{~A}$ possui $4,0 \mathrm{~kb}$ e codifica a enzima dioxigenase, ao passo que $b p h \mathrm{~B}$ possui 1,0 kb e codifica a enzima di-hidrodiol-desidrogenase e $b p h \mathrm{C}$, com $1,0 \mathrm{~kb}$, codifica a enzima di-hidroxi-bifenilo-dioxigenase. A região do bphA é responsável pela especificidade na degradação de congeneres de PCBs (Mondelo, 1989).

Outro exemplo de cepa degradadora já descrita é a Pseudomonas sp. KKS102, que também possui o gene bph no DNA cromossomal (Ohtsubo et al., 2000). A via de degradação do bifenilo é metabolizado por uma série de reações, iniciando pela enzima bifenilo dioxigenase (codificada pelo gene $b p h \mathrm{~A}$, que é composta por 4 subunidades: $b p h \mathrm{~A} 1, b p h \mathrm{~A} 2, b p h \mathrm{~A} 3$ e $b p h \mathrm{~A} 4)$ que converte o bifenilo no composto dihidrodiol através da adição de dois átomos de oxigênio em um dos anéis do bifenilo, seguida da enzima dihidrodiol desidrogenase (codificada pelo gene $b p h \mathrm{~B}$ ) que converte o dihidrodiol em seguida, a enzima 2,3-dihidroxibifenilo dioxigenase (codificada pelo gene $b p h \mathrm{C}$ ), converte o 2,3-dihidroxibifenilo em ácido 2-hidroxil-6-oxo-6-fenilhexa-2,4-dienóico através de meta-clivagem, então a enzima ácido 2-hidroxil-6-oxo-6-fenilhexa-2,4-dienóico hidrolase (bphD) atua resultando em 2 moléculas: ácido benzóico e 2-hidroxipenta-2,4-dienoato, e por fim as enzimas 2-hidroxipenta-2,4-dienoato hidratase ( $b p h \mathrm{E})$, 4-hidroxi-2-oxovalerato aldolase $(b p h \mathrm{~F})$ e acetaldeído desidrogenase $(b p h \mathrm{G})$ convertem o 2-hidroxipenta-2,4dienoato em Acetil CoA e piruvato (Kimbara et al., 1989; Fukuda et al., 1994; Kikuchi et al,. 1994) .

Apesar de se conhecer a via e os genes envolvidos na degradação, pouco se sabe sobre a regulação da expressão do gene $b p h$. Contudo, como já relatado, foi observado que a presença de bifenilo estimula a expressão do gene bph na cepa KKS102. O ORF (open readin frame) $b p h \mathrm{R}$, localizado depois do $b p h \mathrm{~A} 4$ no grupamento do gene $b p h$, codifica para um regulador transcripcional tipo LysR que não é responsável pela expressão do gene $b p h$ (Ohtsubo et al., 2000). No trabalho realizado por Ohtsubo et al. (2000) foi demonstrado que o indutor da expressão do gene bph na KKS102 é o ácido 2-hidroxil-6-oxo-6-fenilhexa-2,4dienóico (HOPDA) que é um produto intermediário da via de degradação do bifenilo e dos PCBs. Segundo estes autores, os genes $b p h$ estão sendo levemente expressos na ausência de bifenilo. Quando adicionado o bifenilo, ocorre a formação de HOPDA a nível basal pela 
fraca atividade dos genes $b p h \mathrm{~A}, b p h \mathrm{~B}$ e $b p h \mathrm{C}$ e pela expressão endógena do gene $b p h \mathrm{D}$. Então, o HOPDA, por um mecanismo de feedback positivo, estimula e ativa todos os genes bph para síntese das enzimas da via de degradação do bifenilo e dos PCBs.

No caso do Rhodococcus sp. RHA1, uma bactéria Gram-positiva degradadora de PCBs, foram isolados e caracterizados os genes catabólicos bifenilo/PCBs $b p h \mathrm{~A} 1 \mathrm{~A} 2 \mathrm{~A} 3 \mathrm{~A} 4$, $b p h \mathrm{C}$ e $b p h \mathrm{~B}$ que codificam respectivamente para as enzimas bifenil dioxigenase, 2,3dihidroxibifenilo1,2-dioxigenase e cis-dihidrodiol deshidrogenase (Masai et al., 1995) (figura 20). Os genes $b p h \mathrm{ACB}$ da RHA1 tem uma característica única se for comparada aos genes bph das Pseudomonas spp. Estes genes são mais similares ao gene tod (49 a 79\% de similaridade), responsáveis pelo catabolismo do tolueno (Zylstra \& Gibson, 1989), do que os genes bph das Pseudomonas spp. (45 a 65\% de silimilaridade)(Erickson \& Mondello, 1992; Fukuda et al., 1994; Kimbara et al., 1989; Taira et al., 1992). Além disso, a ordem dos genes $b p h \mathrm{ACB}$ é diferente dos outros genes $b p h$ cuja ordem é bphABC (Masai et al. 1997).

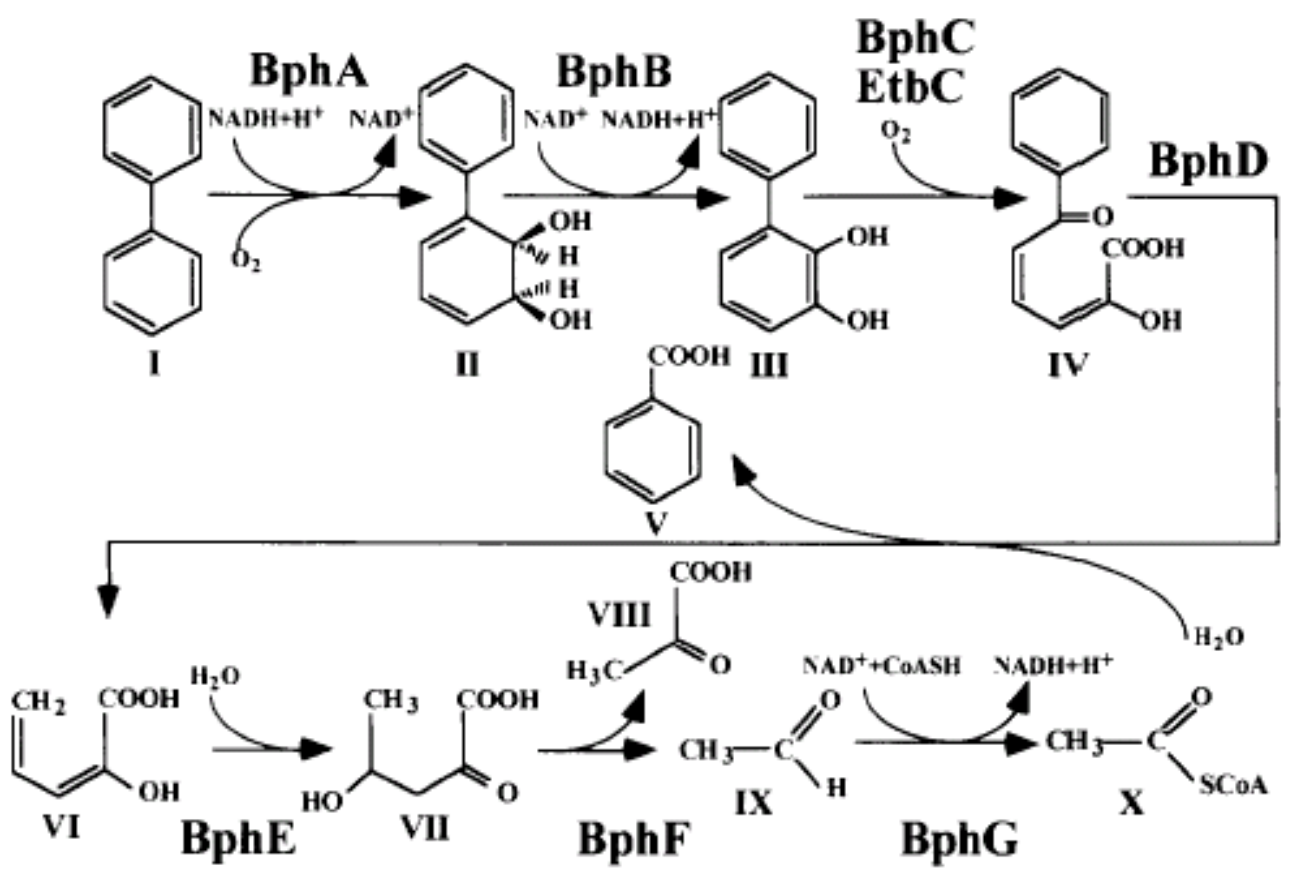

Figura 20: Via metabólica proposta para a degradação de bifenilo e organização genética do gene bph em Rhodococcus sp. RHA1. Correspondência dos genes com as emzimas: bphA complexo da bifenilo dioxigenase, $b p h \mathrm{~B}$ - dihidrodiol desidrogenase; $b p h \mathrm{C}$ e etbC - 2,3DHBP 1,2-dioxigenase; $b p h \mathrm{D}$ - HOPD hidrolase; $b p h \mathrm{E}-$ 2, hidroxipenta-2,4-dienoato hidratase; bphF- 4-hidroxi-2-oxovalerato aldolase e $b p h \mathrm{G}$ - acetaldeído desidrogenase (Masai et al., 1997). 
Estudos comparando operons $b p h$ de diferentes cepas degradadoras demonstraram que algumas bactérias possuem operons similares ou muitas vezes idênticos entre si, enquanto outras apresentam diferentes graus de homologia entre os genes $b p h$, mostrando a grande diversidade desses genes na natureza (Furukawa, 1994). Comparando o gene bphC de Pseudomonas pseudoalcaligenes KF 707 com o da cepa Pseudomonas paucimobilis Q1, foi verificada homologia de $60 \%$. Uma alta homologia foi também observada entre os genes bphA da P. aeruginosa JI104 e os genes bphA1A2A3A4 da P. pseudoalcaligenes KF 707 (Furukawa, 1994). Dados de seqüências de aminoácidos dos diferentes componentes da bifenilo dioxigenase da Pseudomonas sp. LB400 (Erickson \& Mondello, 1992) e da $P$. pseudoalcaligenes KF 707, demonstraram porcentagens de similaridade, variando de 95,6 a $100 \%$. Através destes dados foi possível sugerir um possível ancestral comum (Zylstra et al., 1991).

Além disso, Springael et al. (1993) descreveram a presença de um transposon que carrega os genes bph em uma cepa de Alcaligenes eutrophus A4. Segundo Furukawa (1994), a presença de transposons e a diversidade de genes catabólicos relatados sugerem que os genes bph acumularam mutações ao longo do tempo, mesmo antes da presença de compostos xenobióticos no ambiente. Esses genes seriam necessários para o catabolismo de polímeros aromáticos presentes na natureza, como por exemplo a lignina de plantas.

\subsubsection{Biodiversidade de microrganismos degradadores de PCBs}

O primeiro relato de bactérias capazes de crescer na presença de bifenilo e tetraclorobifenilo foi publicado por Ahmed \& Focht (1973). A partir de então, diversos trabalhos enfocando a habilidade de degradação de bactérias aeróbias autóctones têm sido realizados, principalmente, em regiões de clima temperado (Furukawa et al., 1978, 1979; Bedard et al., 1986, 1987 a, 1987b; Kimbara, 1988).

O trabalho de Ahmed \& Focht (1973) relata duas espécies de Achromobacter capazes de crescer em bifenilo e 4-clorobifenilos, sugerindo que podem haver outros microrganismos com capacidade de degradar PCBs. Após este relato, outros estudos relataram o isolamento e caracterização de bactérias autóctones aeróbias degradadoras de PCBs como por exemplo: Pseudomonas aeruginosa 142, Arthrobacter globiformis KZT, 
Comamonas sp e também alguns fungos como Phanerochate chrysosporium e Aspergillus niger (Yadav et al, 1995; Furukawa et al., 1978, 1979; Bedard et al., 1986 e 1987 a; Kimbara et al., 1988).

Até o momento, as bactérias que apresentam capacidade de degradadar PCBs pertencem principalmente aos grupos das Gram-negativas, incluindo: Achromobacter sp., Alcaligenes eutrophus, Burkholderia sp., Comamonas testosteroni, Pseudomonas paucimobolis, Pseudomonas pseudoalcaligenes, Pseudomonas putida, Pseudomonas testosteroni e Xantomonas maltophilia, mas também alguns actinomicetos, como Rhodococcus erythropolis e Rhodococcus globerus; e bactérias Gram positivas, incluindo: Arthrobacter sp., Corynebacterium sp..

Entre as bactérias degradadoras de PCBs já descritas, a Alcaligenes eutrophus $\mathrm{H} 850 \mathrm{e}$ Pseudomonas LB400, foram isoladas de diferentes locais com habilidade de degradação via anéis clorofênicos 2-; 2,4-;2,5-;2,3,6- e 2,4,5- sendo que todos são constituintes de misturas comerciais como o Arochlor (Bedard et al., 1987b; Nadin et al., 1987). Essas cepas também metabolizam bifenilo e PCBs através da ação da 2,3-dioxigenase, mas podem utilizar-se da enzima 3,4-dioxigenase como forma de biodegradação de PCBs contendo cloro nas posições 2,5-, resultando na produção de diferentes metabólitos como o cisdiidrodiol, um intermediário do 2,5,2',5',-clorobifenilo (Nadin et al., 1987).

No Brasil, o primeiro estudo sobre biodegradação de PCBs com bactérias isoladas de amostras de solo e sedimento foi realizado por Pellizari et al. (1996). Os autores verificaram a capacidade de biodegradação de linhagens isoladas do Rio Pinheiros (SP) e de solo de Cubatão (SP). Algumas dessas linhagens mostraram competência na degradação de mono-a pentaclorobifenilos.

\subsection{Biogeografia e dispersão dos genes catabólicos}

Técnicas de biologia molecular permitem estudar a distribuição e dispersão de diferentes genes catabólicos em comunidades naturais. Estudos de biodiversidade e biogeografia molecular podem ajudar na identificação de microrganismos endêmicos ou cosmopolitas e/ou características genotípicas específicas presentes em microrganismos de diferentes regiões geográficas (Staley, 1999; Staley \& Gosink, 1999). 
Trabalhos como o de Erb \& Wagner-Döbler (1993) e Herrick (1993) demonstraram que muitos isolados degradadores de hidrocarbonetos, apresentaram genes correspondentes às dioxigenases que degradam xileno $(x y l \mathrm{E})$, naftaleno $(n d o \mathrm{~B})$ e tolueno $(\operatorname{tod} \mathrm{C} 1)$.

Em outro estudo, Tiedje et al. (1994) e Pellizari et al. (1996) empregaram dois modelos utilizando como substratos o 3-CBA e o naftaleno, para verificar a dispersão global natural dos genes degradadores. No primeiro modelo, as regiões amostradas foram Rússia, África do Sul, Chile, Califórnia e Canadá. Em todas as regiões continentais, os isolados obtidos foram capazes de degradar o 3-CBA. A partir dos dados, constatou-se que o fenótipo estava distribuído globalmente, mas a dispersão genotípica ocorreu somente dentro da mesma região. No segundo modelo, a dispersão de uma seqüência de DNA em três cepas degradadoras de naftaleno isolados na Ucrânica, Inglaterra e Estados Unidos, apresentaram o operon nah presente em plasmídio, com uma homologia de mais de 99,8\% nas seqüências de nucleotídeos. Este estudo demonstrou que a dispersão natural desse gene e sua transferência para outros hospedeiros é rápida e pode estar distribuída globalmente.

Também foi observado que tanto bactérias Gram-positivas como Gram-negativas apresentam genes de degradação, como foi constatado no trabalho de Smits et al. (1999), em que sondas feitas a partir de PCR dos genes alk B de Pseudomonas oleovorans Gpo1 e gene alkM de Acinetobacter sp. ADP1, que codificam para alcano-hidroxilases, hibridaram com isolados filogeneticamente distintos.

A dispersão dos genes de degradação também foi observada em bactérias psicrotróficas, sugerindo uma grande potencialidade para biorremediação de locais contaminados onde ocorrem baixas temperaturas. Whyte et al. (1996) estudaram 135 cepas de bactérias isoladas de diferentes locais contaminados por hidrocarbonetos no Canadá e em ambientes protegidos próximos a região polar Ártica. Através da técnica de PCR e hibridação foram detectados isolados que possuíam genes homólogos ao tod $\mathrm{C} 1, x y l \mathrm{E}$ e ndoB. No trabalho de Whyte et al. (1997) também foi constatado que microrganismos psicotróficos podem apresentar mais de um gene de degradação de diferentes compostos, visto que genes responsáveis pela degradação de alcanos (alk) e naftalenos (nah) se encontravam no mesmo microrganismo.

Contudo também foram realizados trabalhos da dispersão de genes catabólicos em região tropical. No trabalho realizado por Pellizari et al. (1996), verificou-se que 20\% dos 
isolados brasileiros positivos para o iniciador nah, não apresentaram seqüências de nucleotídeos idênticas, sugerindo que a dispersão do operon nah na região tropical não estaria completa. Outro estudo de dispersão de genes catabólicos comparando uma região tropical (Brasil) com uma região polar (Antártica) foi realizado por Luz (2001) que revelou uma dispersão evidente de diferentes genes catabólicos envolvidos na degradação de hidrocarbonetos do petróleo e compostos organoclorados nas duas regiões. Entre os genes de dioxigenases estudados por Luz (2001), pode-se constatar a predominância do gene tod $\mathrm{C} 1$ para as amostras de solo do Brasil e os genes tod $\mathrm{C} 1$ e $b p h \mathrm{~A}$ para as amostras de solo da Antártica. No caso do estudo das monoxigenases realizado por Luz (2001), as análises de PCR e hibridação por "Southern Bolt" apresentaram, na maioria dos solos contaminados e protegidos em ambas as regiões, predominância dos genes alkB1 e alkB2.

\subsection{Revisão bibliográfica da área de estudo}

\subsubsection{Localização da Baía de Santos}

A região da Baía de Santos (Figura 17), é constituída do estuários de Santos e São Vicente. Esses estuários são supridos por um conjunto de mananciais provenientes das encostas da Serra do Mar ou de origem na própria baixada. Os rios que nascem na Serra, apresentam inicialmente um regime torrencial, mas ao chegarem à baixada, mudam de regime devido à pequena declividade desta formação, que dificulta o escoamento das águas. Este fenômeno causa a formação de um labirinto de canais e meandros, que na porção central e a noroeste da área individualizam as Ilhas de São Vicente e Santo Amaro. Contornando as margens desses canais, existem manguezais que ocupam grandes extensões da planície até onde é atingida pela maré alta (FUNDESPA, 1994). 


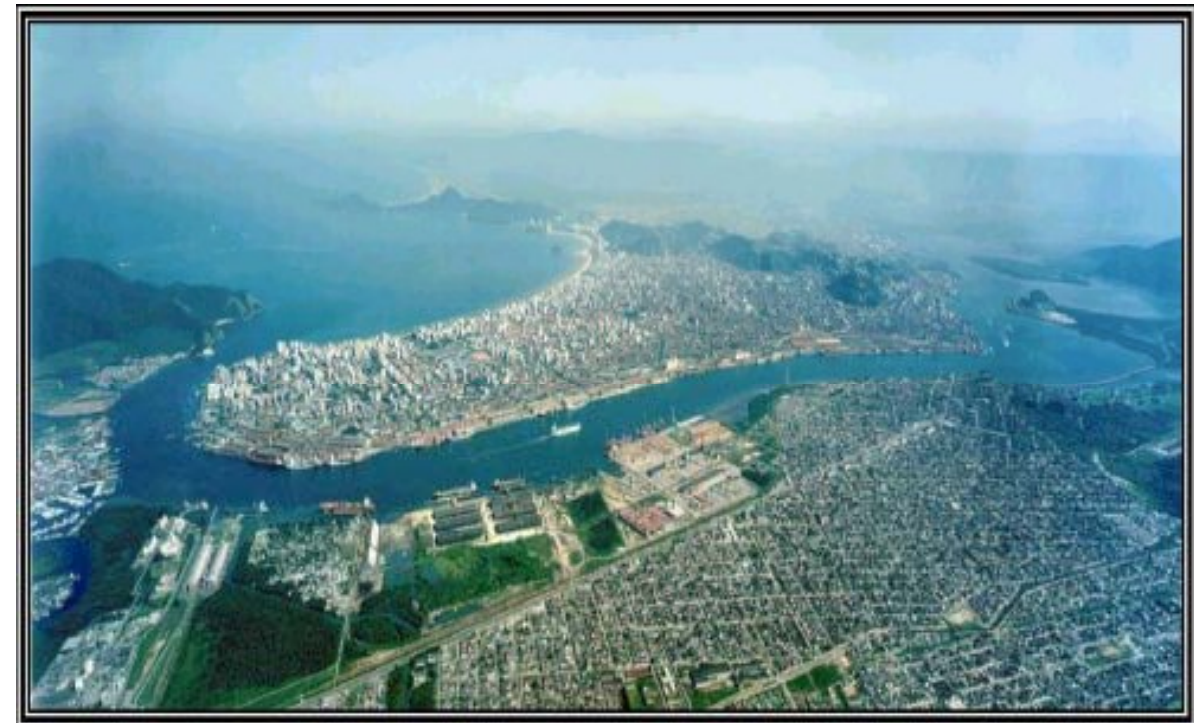

Figura 21: Foto aérea da área de estudo

A Baixada Santista constitui uma unidade geográfica diferenciada dentro do contexto regional em função de suas características físicas e do processo de ocupação humana (Ribeiro Neto \& Oliveira, 1989). Vários critérios de classificação, em especial os aspectos climáticos e geomorfológicos, fazem com que essa região seja uma área transicional entre dois sistemas bastante diferenciados, os litorais sul e norte de São Paulo, apresentando as características de ambos os setores. Isto lhe confere, mesmo sem os impactos antrópicos, uma complexidade paisagística única (Araújo Filho, 1969).

\subsubsection{Caracterização climática}

A área apresenta um clima litorâneo quente e úmido (ou superúmido), característico do tipo tropical úmido com altos índices de precipitação pluviométrica, sujeita a uma ampla oscilação térmica, devido à ação dinâmica da Frente Polar Atlântica, sofrendo ação direta do sistema de brisas e não possuindo estação seca definida. Sendo o mês de Fevereiro o mais quente e chuvoso, com uma temperatura média de $25,3^{\circ} \mathrm{C}$ e $301 \mathrm{~mm}$ de precipitação e o mês de julho sendo o mais frio (média de $18,2^{\circ} \mathrm{C}$ ) e Agosto como o mais seco $(90,6 \mathrm{~mm})$. A temperatura média anual é de $22^{\circ} \mathrm{C}$ e os totais pluviométricos anuais oscilam entre 2000 mm no litoral e 4500mm nas encostas (Santos, 1965; FUNDESPA, 1994). 


\subsubsection{Características geológicas e geomorfológicas}

Na caracterização geomorfológica do Estado de São Paulo (IPT, 1981), a planície e a Baía de Santos se encontram na Planície Costeira, conforme definido por Almeida (1964 apud IPT, 1981), correspondente à província fisiográfica denominada de litoral por Ab'Saber \& Bernardes (1958 apud IPT, 1981). Esta província corresponde à área drenada diretamente para o mar, constituindo o rebordo do Planalto Atlântico, onde se destaca uma região serrana contínua que, à beira-mar, cede lugar a uma sequência de planícies de várias origens (Almeida, 1964 apud IPT, 1981).

No seu contexto geológico regional a área é limitada a oeste pela Falha de Cubatão e a leste pela Falha de Santos, constituindo-se de rochas do Complexo Costeiro e da Suíte Granítica Indiferenciada (Almeida \& Carneiro, 1998).

O domínio da Província Costeira se subdivide nas subzonas Serra do Mar e Baixada Litorânea.

A planície costeira de Santos é delimitada pela Serra de Mongaguá, ao sul, e pela Ilha de Santo Amaro, ao norte, apresentando uma extensão de 40km e uma largura máxima de $15 \mathrm{~km}$. Nas partes central e nordeste, a planície é drenada por uma rede de lagunas e canais de maré que delimitam as Ilhas de São Vicente e de Santo Amaro.

A planície costeira é constituída, predominantemente, por areias marinhas, depósitos argilo-arenosos, flúvio-lagunares e sedimentos de mar raso (fundo de baía). Segundo Fúlfaro \& Ponçano (1976), os sedimentos são preferencialmente compostos por silte fino, graduando até areia muito fina, configurando, em princípio, um ambiente de baixa energia e baixa taxa de floculação, sendo o estuário santista uma região de grande equilíbrio no que se refere à sedimentação, não apresentando características de assoreamento rápido (FUNDESPA, 1994).

\subsubsection{Dinâmica sedimentar no estuário e na Baía de Santos}

O modelo atual de circulação e sedimentação do estuário de Santos foi estabelecido por Fúlfaro \& Ponçano (1976), que constataram que os sedimentos superficiais de fundo originam-se do aporte fluvial e da erosão local de bancos e da plataforma externa. 
Estes autores observaram que no alto estuário santista as águas provenientes da Serra do Mar entram no estuário, em especial na região do canal do porto, originando um predomínio de fluxo unidirecional que se propaga em direção à baía. Esta descarga líquida e de sólidos ocorre, principalmente, pelos rios Cubatão, Perequê, Mogi, Quilombo e Jurubatuba. A faixa de mangue que circunda o estuário retém, no entanto, grande parte da carga transportada por tração, liberando, para os canais, apenas a carga transportada em suspensão, de natureza síltico-argilosa.

A área do médio estuário sofre a influência das correntes de maré, estando sujeita à movimentação provocada por ação marinha a partir da Baía de Santos. O contato entre o fluxo unidirecional fluvial e o fluxo marinho é vertical, correspondendo a uma zona de quebra de energia de transporte do sistema.

Desta forma, o alto e médio estuário santista estão submetidos a um processo geral de sedimentação de baixa energia, com predomínio de sedimentação síltico-argilosa, sendo uma região de grande equilíbrio no que se refere à sedimentação, onde taxas elevadas de sedimentação ocorrem apenas localmente, como nas extremidades sul dos canais de São Vicente e do Porto, junto à desembocadura da baía, no canal de Bertioga e no Largo do Caneú.

Na Baía de Santos a movimentação de sedimentos é comandada, basicamente, pela movimentação das correntes, resultado da interferência das águas oceânicas com as águas provenientes do estuário. Portanto, o mecanismo hidrodinâmico é determinante na sua compartimentação sedimentar (Ponçano \& Fúlfaro, 1976). A distribuição de sedimentos de fundo na área é caracterizada por dois setores distintos. Um localiza-se a oeste, onde predominam as areias e outro a leste, com predominância de sedimentos finos. Esse padrão de distribuição é associado, pelos autores, à influência da ação marinha a oeste, devido ao fluxo de SW para NE da corrente costeira que penetra na baía junto à Ponta do Itaipu e que atinge a porção mais interna desta ao longo das praias de São Vicente e de Santos, transportando e depositando sedimentos arenosos na área, e à influência do canal do porto a leste, cujo fluxo, que carreia sedimentos síltico-argilosos, converge com o fluxo das correntes costeiras de oeste, acarretando na deposição de parte desta carga de sedimentos finos nesta porção da baía. 
Furtado et al. (1999), analisando as características da matéria orgânica sedimentar na baía de Santos, observaram que os teores de carbono orgânico, nitrogênio e enxofre totais são mais significativos na porção central não sendo, no entanto, altos para a área como um todo. Destaca-se o teor obtido para o enxofre, próximo ao difusor do emissário submarino do José Menino, que chega a ser mais de 100 vezes superior a outros valores da área e mais de duas vezes superior aos valores de estações adjacentes.

\subsubsection{Histórico da impactação ambiental na área}

Os ecossistemas litorâneos da baixada santista têm sofrido nas últimas décadas impactos antrópicos extremamente negativos ao desenvolvimento de sua fauna e flora, com reflexos inclusive sobre a saúde humana. Entre os tensores ambientais mais atuantes na descaracterização ambiental da região destacam-se as intensas descargas de efluentes industriais, portuários e domésticos lançados indiscriminadamente ao longo dos rios e canais estuarinos, assim como o desmatamento e a ocupação desordenada de áreas localizadas nas periferias dos municípios (Bonetti, 2000).

Bonetti Filho (1996) elaborou, baseado em diversos autores, uma síntese dos principais fatos históricos que levaram ao atual estado de degradação da área que será descrita a seguir.

O crescimento da baixada santista não foi um processo que tenha ocorrido de forma contínua, mas sim em fases sucessivas de desenvolvimento social e econômico. Uma primeira fase de desenvolvimento esteve ligada à ampliação do porto e construção, no final do século XIX, das estradas de ferro que ligaram diretamente o Planalto Paulista à Baixada Santista.

A partir do ano de 1918, quando instalou-se uma fábrica de papel e, principalmente, a partir dos anos 20, quando foi construída a usina hidrelétrica da Light, a região experimentou um segundo surto de crescimento. Esta fase marcou a primeira mudança significativa na dinâmica estuarina, visto que a indústria de papel utilizava a água do Rio Cubatão, tanto para a alimentação de sua planta industrial, como também como corpo receptor de seus rejeitos de processamento. Por outro lado, a usina liberava, neste mesmo 
canal fluvial, um volume significativo de água doce, proveniente do planalto, que induziu modificações das condições da salinidade e circulação da região do alto estuário.

Anteriormente a estas interferências, os únicos resíduos industriais na região do alto estuário que poderiam causar impacto sobre a região estuarina eram devidos a um curtume, implantado em 1895, único empreendimento industrial existente até o ano de 1918.

A partir da construção de uma nova opção rodoviária entre o planalto e a baixada, a Via Anchieta, no início da década de 40, a região passou a experimentar um aumento do fluxo turístico e de serviços. Porém, a ampliação da capacidade de geração de energia pela Light, com a construção de uma usina subterrânea, entre os anos de 1956 e 1962, possibilitou a instalação de uma refinaria de petróleo, um pólo petroquímico e, posteriormente, um complexo siderúrgico, modificando sensivelmente as condições hidrodinâmicas e ambientais do estuário.

Os pólos petroquímico e siderúrgico utilizam, pelo menos em parte, como fonte de água doce para suas plantas industriais, a água dos rios que cortam a planície costeira além de pequenas quedas d'água, existentes nos contrafortes da Serra do Mar.

A partir da ampliação da capacidade hidrelétrica instalada, o volume de ingresso de água doce no estuário, proveniente do planalto, sofreu um sensível incremento sendo que, a este aporte de água doce, está associado um volume considerável de material em suspensão, rico em elementos metálicos e orgânicos, resultantes das atividades industriais e urbanas nas áreas do alto estuário e escarpas adjacentes.

Este período de rápido crescimento, ocorrido entre o final dos anos 50 e início da década de 60, implicou, não apenas na ampliação da área portuária, mas também na necessidade de dragagens contínuas do leito do estuário, a fim de possibilitar o acesso ao porto de embarcações de maior tonelagem, como também o acesso até regiões do alto estuário onde foram construídos cais exclusivos para a indústria siderúrgica.

Somente após a construção da Rodovia dos Imigrantes, no início dos anos 70, a partir da Serra do Mar sobre a área de manguezal que circunda o estuário, foram implementados programas de controle ambiental visando diminuir o aporte de rejeitos industriais ao estuário, e de bombeamento das águas do planalto para a geração de energia e posterior deságüe no alto estuário, alterando novamente a dinâmica do sistema. 
A explosão populacional que acompanhou este ciclo, associada à ausência de suporte urbano no que concerne às obras de saneamento básico e à multiplicação das fontes impactantes, levou ao comprometimento sanitário das águas e das praias da região, passando toda Ilha de São Vicente a ter sua balneabilidade considerada imprópria na década de 80. Um dos principais motivos da falta de balneabilidade das praias santistas, apesar de não ser o único, visto as diversas fontes de impactação industrial existentes na área estuarina descritas acima, tem sido o aporte de esgotos domésticos ligados clandestinamente aos canais de escoamento das águas pluviais que atravessam a cidade e que deságuam na praia. Esta situação foi revertida artificialmente, no verão de 1991/92, através do fechamento dos canais e interligação destes a uma rede que leva o material até uma estação de tratamento de efluentes, que são posteriormente despejados pelo emissário submarino do José Menino na parte central da baía. A eficiência deste sistema é discutível, visto que transbordamentos dos canais já foram observados em épocas de maior pluviosidade. Braga et al. (2000) confirmaram que ainda ocorre o aporte de águas contaminadas, oriundas dos canais, na baía, devido aos altos teores de nitrogênio orgânico dissolvido, amônia, nitrato, coliformes totais e coliformes fecais encontrados nas águas adjacentes à orla.

\subsubsection{Principais fontes de poluição}

As principais fontes de poluição na região estão relacionadas à presença de 23 indústrias, responsáveis por um total de 2,6\% do PIB brasileiro (KucinskI, 1982 apud Bonetti, 2000). Dados da CETESB de 1986 indicam que a carga média de poluentes lançados nos corpos d'água, na época do auge da problemática ambiental de Cubatão, chegava a $100.000 \mathrm{~kg} / \mathrm{mês}$, sendo os efluentes industriais da Refinaria de Petróleo, da Cosipa (siderúrgica) e da Ultrafértil (fertilizantes) responsáveis por mais de $90 \%$ da carga tóxica total despejada no ambiente (principalmente nos rios Cubatão, Perequê e Piaçaguera). Tommasi \& Griesinger (1983 apud Bonetti, 2000) listam como principais poluentes associados a estes três ramos de atividades os seguintes:

- Refinarias: fenóis, compostos de enxofre e efluentes com elevado DBO;

- Siderúrgicas: ácidos, cianetos, fenóis, álcalis, óleo, etc.; 
- Indústrias de fertilizantes: fósforo, sílica, flúor, sólidos em suspensão, etc.

Além destas, há a poluição química gerada principalmente no Pólo Industrial de Cubatão, que é a que tem recebido maior atenção da mídia. A Baixada Santista sofre também os impactos de outras inúmeras fontes poluidoras. Nos estuários, em particular, temos a ação degradante: (1) dos esgotos domésticos e municipais lançados in natura nas águas costeiras; (2) da disposição de resíduos sólidos às margens dos canais estuarinos ou em áreas de mangue; (3) do desmatamento dos manguezais, provocando o assoreamento das áreas marginais; (4) das atividades portuárias, entre elas a dragagem dos canais de navegação, que aumenta a turbidez das águas pela ressuspensão e facilita as trocas químicas entre a água e o sedimento; (5) da construção de marinas; (6) dos derrames industriais, entre outras (Bonetti, 2000).

Essa diversidade e abundância de fontes impactantes foi potencializada pela falta de um planejamento adequado e pela inexistência de leis ambientais na época da implantação do parque industrial. As conseqüências desse desenvolvimento não sustentável estão refletidas nas dificuldades encontradas atualmente para o melhoramento da qualidade ambiental na região. 


\section{MATERIAL E MÉTODOS}

\subsection{Pontos de coleta e método de amostragem}

Foram coletadas 18 amostras de sedimento em 9 pontos localizados na região do estuário de Santos (SP), apresentados na figura 22. A coleta foi realizada com o apoio da CETESB. Os sedimentos foram coletados com o auxílio de um pegador de fundo de inox (figura 23), transferidos para um frasco estéril e para um recipiente laminado para análises microbiológicas e químicas respectivamente. As amostras foram mantidas sob refrigeração durante o transporte e submetidas dentro de 24horas aos testes de cultivo microbiológico. As amostras para análise química foram estocadas em freezer até o momento da análise. A descrição completa dos pontos, bem como sua localização georeferenciada se encontram na tabela 5 .

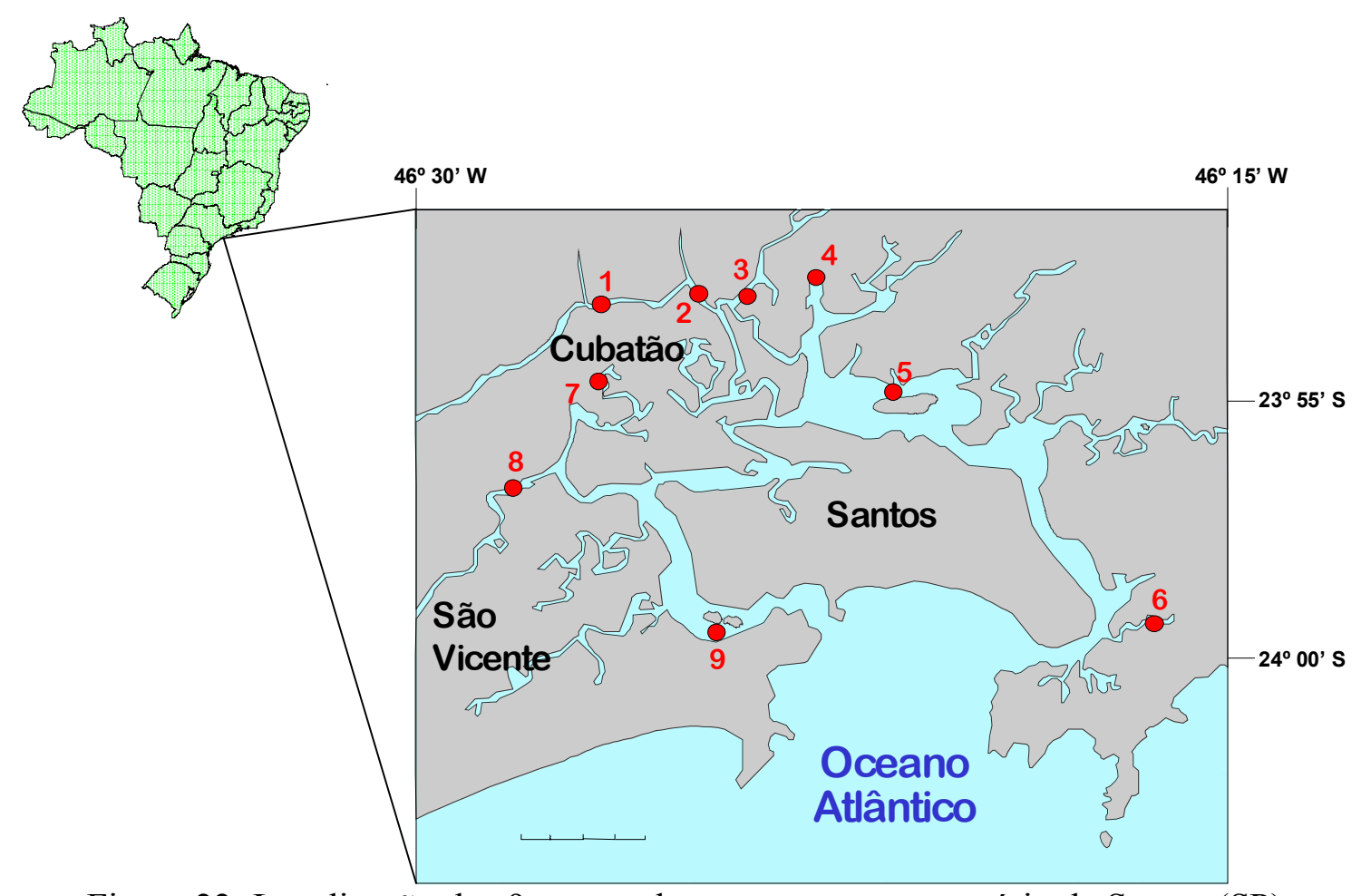

Figura 22: Localização dos 9 pontos de amostragem no estuário de Santos (SP). 


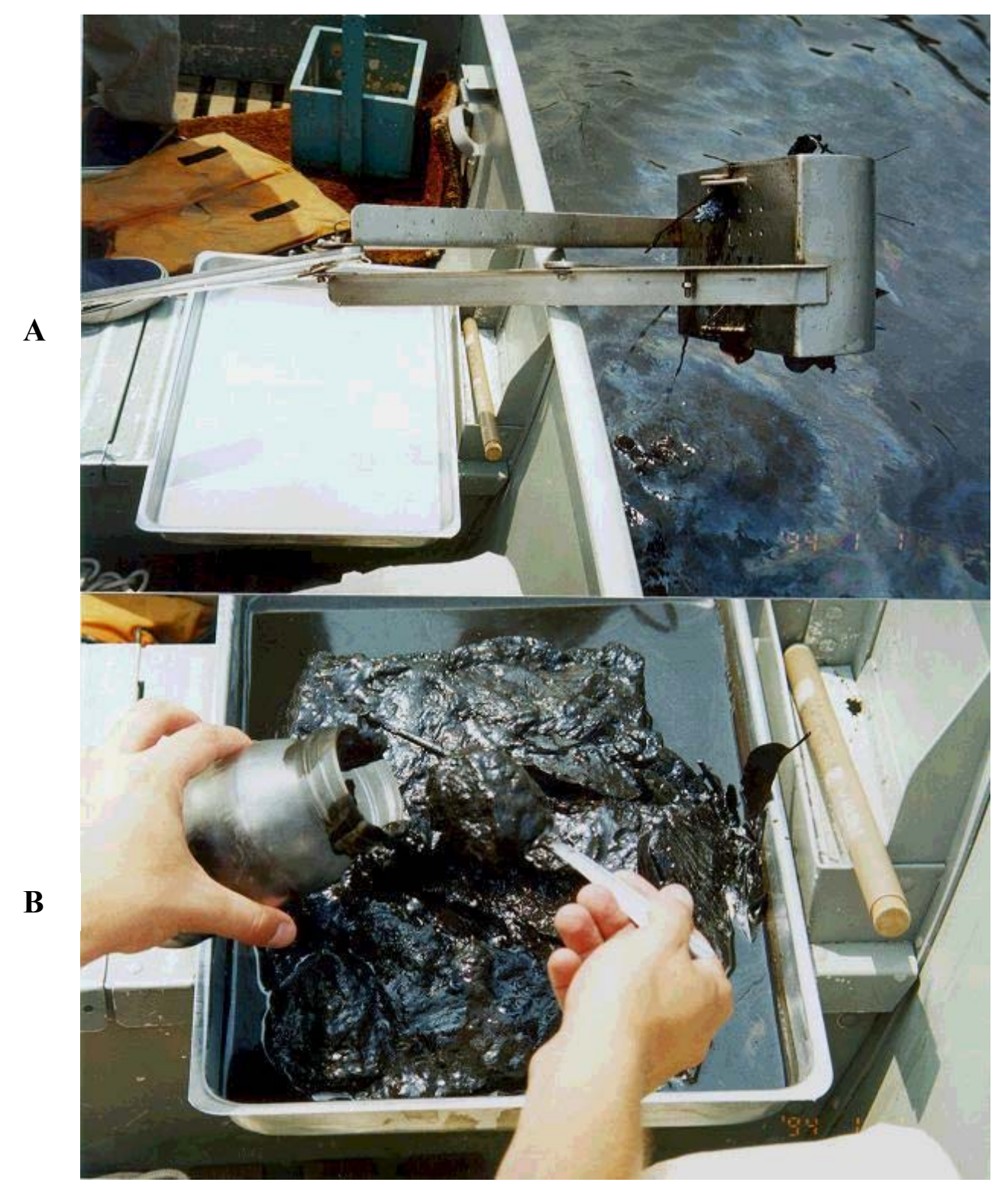

Figura 23: A - Coleta do sedimento com pegador de fundo de inox (Van Veen) B -Transferência do sedimento coletado para frasco estéril para análise microbiológica 
Tabela 5. Descrição dos pontos de amostragem realizados no estuário de Santos (SP).

\begin{tabular}{|c|c|c|}
\hline Ponto de coleta e descrição & $\begin{array}{c}\text { Localização } \\
\text { georeferenciada }\end{array}$ & $\begin{array}{l}\text { Data da } \\
\text { Coleta }\end{array}$ \\
\hline $\begin{array}{l}\text { Ponto } 1 \text { - rio Cubatão - barragem da Petrobrás. Água doce, sem } \\
\text { influência da cunha salina. Localiza-se à montante de uma barragem, } \\
\text { recebe influência do Alto Cubatão e do Canal de Fuga, cuja água vem } \\
\text { da Represa Billings, além de receber água da Sabesp e efluentes da Cia } \\
\text { Santista de Papel e da Petrobrás. }\end{array}$ & $\begin{array}{l}23^{\circ} 52^{\prime} 46,0^{\prime \prime} \mathrm{S} \\
46^{\circ} 25^{\prime} 52,8^{\prime} \mathrm{W}\end{array}$ & $10 / 10 / 2000$ \\
\hline $\begin{array}{l}\text { Ponto } 2 \text { - rio Cubatão, à jusante da ponte de ferro. Água doce com } \\
\text { influência da cunha salina. Localiza-se perto de uma estrada de ferro, } \\
\text { onde há um posto de monitoramento das águas da CETESB. Recebe } \\
\text { influência de indústrias como a Ultra Fértil, Fafer, Refinaria Presidente } \\
\text { Bernardes, Cia Brasileira de Estireno, além do esgoto de Cubatão. }\end{array}$ & $\begin{array}{l}23^{\circ} 25^{\prime} 33,0^{\prime \prime} \mathrm{S} \\
46^{\circ} 24^{\prime} 37,0^{\prime} \mathrm{W}\end{array}$ & $03 / 10 / 2000$ \\
\hline $\begin{array}{l}\text { Ponto } 3 \text { - rio Piaçaguera. Água doce com influência da cunha salina. } \\
\text { Recebe água do rio Mogi e influência de indústrias como a Coperbrás, } \\
\text { Solo Rico, Manah, Ultra Fértil e COSIPA. }\end{array}$ & $\begin{array}{l}23^{\circ} 52^{\prime} 22,6^{\prime \prime} \mathrm{S} \\
46^{\circ} 233^{\prime} 34,6^{\prime \prime} \mathrm{W}\end{array}$ & $03 / 10 / 2000$ \\
\hline $\begin{array}{l}\text { Ponto } 4 \text { - estuário de Santos, em frente à COSIPA. Água doce com } \\
\text { influência da cunha salina, com níveis mais eleveados de salinidade, } \\
\text { chegando à } 21,3 \% \text { no fundo e } 3,8 \% \text { na superfície. Recebe influência } \\
\text { direta da COSIPA. }\end{array}$ & $\begin{array}{l}23^{\circ} 52^{\prime} 31,1^{\prime \prime} \mathrm{S} \\
46^{\circ} 22^{\prime} 35,9^{\prime} \mathrm{W}\end{array}$ & $03 / 10 / 2000$ \\
\hline $\begin{array}{l}\text { Ponto } 5 \text { - estuário de Santos, no Largo do Caneus. Água doce com } \\
\text { influência da cunha salina. Esta área possui efeito direto de indústrias } \\
\text { siderúrgicas. }\end{array}$ & $\begin{array}{l}23^{\circ} 54^{\prime} 42,8^{\prime \prime} \mathrm{S} \\
46^{\circ} 20^{\prime} 33,2^{\prime \prime} \mathrm{W}\end{array}$ & $17 / 10 / 2000$ \\
\hline $\begin{array}{l}\text { Ponto } 6 \text { - rio Santo Amaro. Água doce com influência da cunha salina, } \\
\text { com níveis mais elevados, chegando a } 22,6 \% \text { no fundo. Esta área } \\
\text { possui um estaleiro que recebe embarcações de pesca. }\end{array}$ & $\begin{array}{l}23^{\circ} 59^{\prime} 0,4^{\prime \prime} \mathrm{S} \\
46^{\circ} 16^{\prime} 57,6^{\prime \prime} \mathrm{W}\end{array}$ & $17 / 10 / 2000$ \\
\hline $\begin{array}{l}\text { Ponto } 7 \text { - rio Santana. Água doce com influência da cunha salina. } \\
\text { Possui boas condições de preservação. }\end{array}$ & $\begin{array}{l}23^{\circ} 54^{\prime} 29,8^{\prime \prime} \mathrm{S} \\
46^{\circ} 26^{\prime} 54,6^{\prime \prime} \mathrm{W}\end{array}$ & $27 / 10 / 2000$ \\
\hline $\begin{array}{l}\text { Ponto } 8 \text { - rio Branco. Água doce com influência da cunha salina. É } \\
\text { relativamente preservado, embora tenha influência de esgoto oriundo de } \\
\text { um presídio e de moradores da região. }\end{array}$ & $\begin{array}{l}23^{\circ} 57^{\prime} 1,11^{\prime \prime} \mathrm{S} \\
46^{\circ} 28 ' 23,9^{\prime \prime} \mathrm{W}\end{array}$ & $27 / 10 / 2000$ \\
\hline $\begin{array}{l}\text { Ponto } 9 \text { - estuário de São Vicente, no canal de Barreiros. Água doce } \\
\text { com influência da cunha salina. É influenciado diretamente pelos rios } \\
\text { Mariana, Branco e Piaçabuçu, o qual recebe esgoto de São Vicente. }\end{array}$ & $\begin{array}{l}23^{\circ} 58^{\prime} 28,4^{\prime \prime} \mathrm{S} \\
46^{\circ} 24 ’ 48,7^{\prime \prime} \mathrm{W}\end{array}$ & $27 / 10 / 2000$ \\
\hline
\end{tabular}

Fonte: CETESB-SP

\subsection{Caracterização das áreas estudadas}

\subsubsection{Parâmetros físico-químicos}

No momento da coleta foram determinados pelos técnicos da CETESB, os valores de $\mathrm{pH}$, temperatura e potencial redox da água e do sedimento, a salinidade da água e a profundidade em que a amostra foi coletada.

$\mathrm{O} \mathrm{pH}$, a temperatura e o potencial redox foram obtidos através de um $\mathrm{pH}-$ metro/condutivímetro portátil dotado de um eletrodo de $\mathrm{pH}$ combinado com sensor térmico 
para medir a temperatura e o $\mathrm{pH}$; e de um outro eletrodo para medir o potencial redox. A salinidade foi medida in situ com um salinômetro portátil.

\subsubsection{Análise granulométrica dos sedimentos}

A análise granulométrica das amostras coletadas foram realizadas em um sedimentômetro laser Mastersizer 2000, da Malvern, com capacidade de análise de

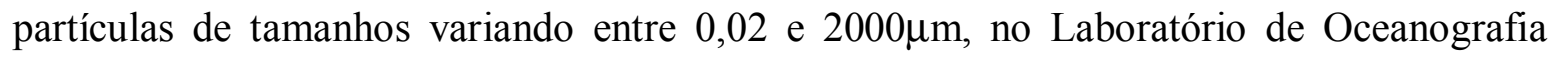
Geológica, do Instituto Oceanográfico da USP.

\subsubsection{Análise química dos sedimentos}

Os procedimentos de análise dos sedimentos seguiram basicamente o recomendado em UNEP (1991). As amostras de sedimento foram secas em estufa a $50^{\circ} \mathrm{C}$ e posteriormente extraídas e analisadas no Laboratório de Química Orgânica Marinha do Instituto Oceanográfico da USP, segundo Figura 24.

Foram extraídos os hidrocarbonetos e PCBs de sub amostras de 1 a 5 g de sedimento secos em Soxhlet com $80 \mathrm{~mL}$ de uma mistura 50\% diclorometano/n-hexano, aonde foram adicionados $1 \mathrm{~mL}$ de uma mistura de padrões internos tanto para os hidrocarbonetos como para os PCBs. Os extratos obtidos foram concentrados a $1 \mathrm{~mL}$ em evaporador rotativo a vácuo, em banho de $40^{\circ} \mathrm{C}$ e em seguida foi feito um tratamento com raspas de cobre para eliminação do enxofre presente nas amostras, o que pode interferir nas análises por cromatografia em fase gasosa. Esses extratos tratados foram submetidos a cromatografia de adsorção (purificação e separação) com coluna contendo 3,2 g de sílica gel (70-230 mesh, Merck) sobre 1,8 g de alumina (70-230 mesh, Merck) e cerca de $1 \mathrm{~cm}$ de sulfato de sódio desidratado. Para separar os hidrocarbonetos alifáticos dos aromáticos policíclicos (HPAs) utilizou-se 2 frações móveis de diferentes polaridades. Para eluir os alifáticos (fração1-F1) utilizou-se $10 \mathrm{~mL}$ de n-hexano, enquanto que para os HPAs utilizou-se $20 \mathrm{~mL}$ de $30 \%$ de diclorometano em n-hexano (fração-F2). Os PCBs foram analisados nas 2 frações, a partir da mistura de $500 \mu \mathrm{L}$ da fraçãoF1 e $500 \mu \mathrm{L}$ da fração F2.. 
Alíquotas de $1 \mu \mathrm{L}$ de cada fração F1 dos hidrocarbonetos, foi injetada em cromatógrafo a gás da Hewlett Packard, modelo 5890 II, equipado com o detetor de ionização de chama mantido a $325^{\circ} \mathrm{C}$ e com coluna capilar Ultra 2 da Hewlett Packard de 25 m de comprimento e $0,32 \mathrm{~mm}$ de diâmetro interno com fase de $5 \%$ fenil metil silicona. A temperatura do injetor foi de $280^{\circ} \mathrm{C}$, sendo que a injeção foi feita sem divisão de fluxo. A rampa da temperatura foi: inicial $40^{\circ} \mathrm{C}$ por 1 minuto, $20^{\circ} \mathrm{C} / \mathrm{min}$ até $60^{\circ}, 5^{\circ} \mathrm{C} / \mathrm{min}$ até $290^{\circ} \mathrm{C}$, $10^{\circ} \mathrm{C} / \mathrm{min}$ até $300^{\circ} \mathrm{C}$ e isotérmico por 10 minutos. Enquanto que, alíquotas de $2 \mu \mathrm{L}$ dos PCBs

Os cálculos finais foram feitos pela relação de áreas com um padrão interno, levando-se em conta o fator de resposta calculado para cada hidrocarboneto a partir da análise de misturas preparada com padrões de hidrocarbonetos alifáticos e aromáticos policíclicos. Na fração $\mathrm{F} 1$, que continha os hidrocarbonetos alifáticos, foram analisados os n-alcanos contendo 12 a 35 átomos de carbono e os isoprenóides pristano e fitano utilizando-se o n-hexadeceno, n-tetradeceno e n-eicoseno como padrões internos.

$\mathrm{Na}$ fração F2, que contém os hidrocarbonetos aromáticos policíclicos (PAHs), foram analisados 25 compostos, dos quais foram obtidos autênticos padrões de referência. O padrão interno para os aromáticos foi o 9,10-dihidroantraceno e os "surrogates" são os aromáticos deuterados: naftaleno-d8, acnafteno-d10, fenantreno-d10, criseno-d12, perilenod12. A coluna e a rampa de temperatura foram as mesmas que para as análises de F1. O espectrômetro de massa foi da V.G. Masslab - Fisons modelo TRIO 1000 onde a análise foi feita em modo SIM, com a temperatura da interface a $300^{\circ} \mathrm{C}$ e da fonte de íons a $270^{\circ} \mathrm{C}$

No caso dos PCBs, alíquotas de $2 \mu \mathrm{L}$ da mistura das frações, foram injetadas em cromatógrafo a gás da Hewlett Packard, modelo 5890 II, equipado com o detetor de captura de elétrons mantido a $325^{\circ} \mathrm{C}$ e com coluna capilar Ultra 2 da Hewlett Packard de $25 \mathrm{~m}$ de comprimento e $0,32 \mathrm{~mm}$ de diâmetro interno com fase de $5 \%$ fenil metil silicona. A temperatura do injetor foi de $275^{\circ} \mathrm{C}$, sendo que a injeção foi feita sem divisão de fluxo. A rampa da temperatura foi: inicial $100^{\circ} \mathrm{C}$ por 1 minuto, $5^{\circ} \mathrm{C} / \mathrm{min}$ até $140^{\circ}, 1,5^{\circ} \mathrm{C} / \mathrm{min}$ até $250^{\circ} \mathrm{C}, 10^{\circ} \mathrm{C} / \mathrm{min}$ até $300^{\circ} \mathrm{C}$ e isotérmico por 5 minutos. 


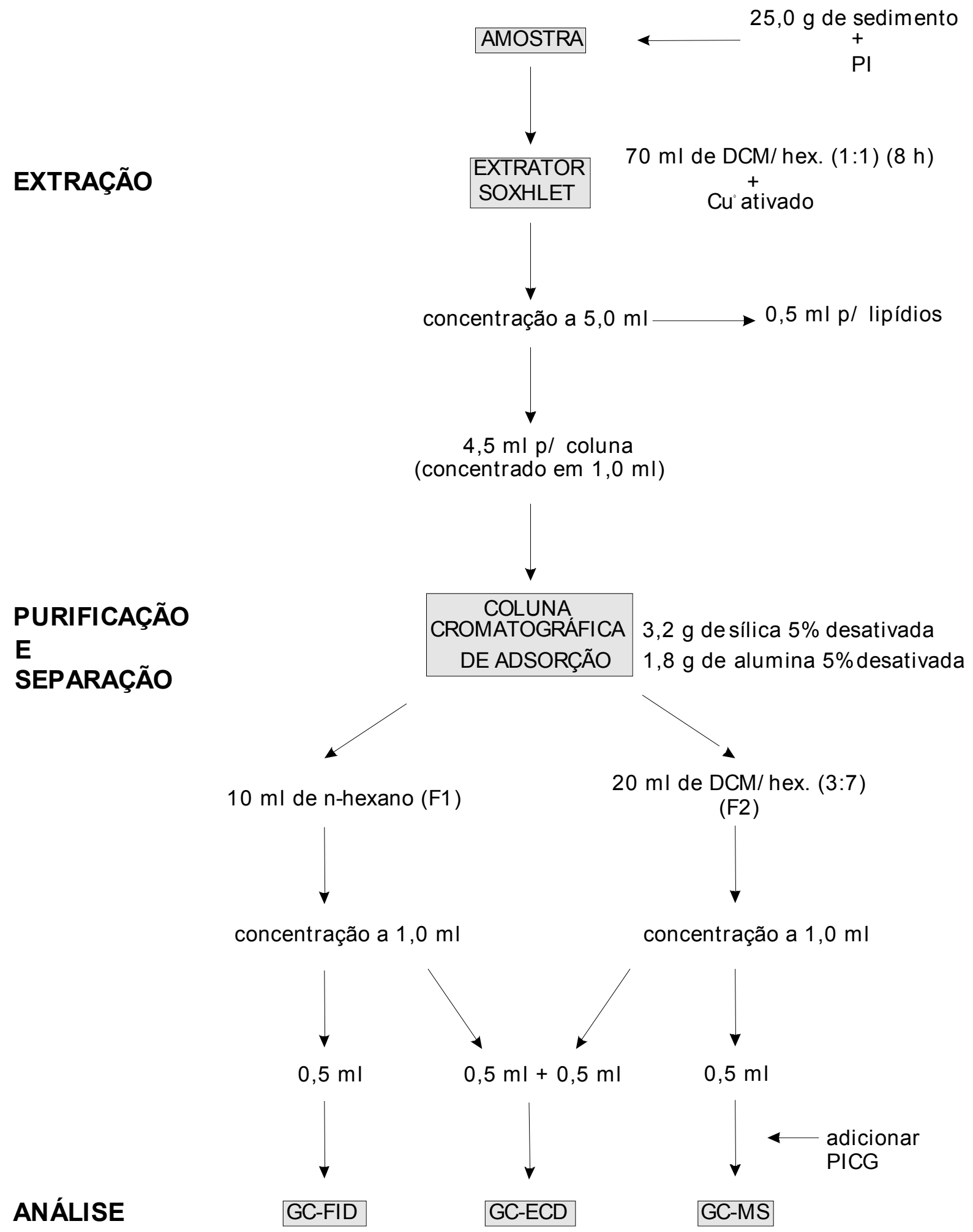

ANÁLISE

C-FID

GC-ECD 


\subsubsection{Contagem de bactérias heterotróficas}

Foi realizada contagem de bactérias heterotróficas segundo APHA (1995) e Alef \& Nannipieri (1995).

Nesta análise, $10 \mathrm{~g}$ de sedimento de cada a amostra foram pesadas em condições de assepsia e colocadas em um erlenmayer contendo $90 \mathrm{~mL}$ de água tamponada (diluição de $10^{-1}$ ). A amostra então foi deixada agitando por 1 hora em shaker a temperatura ambiente. Após este período as amostras foram retiradas do shaker e colocadas em bancada para que o solo pudesse sedimentar por 15 a 20 minutos para então, continuar as demais diluições. Cada diluição foi plaqueada em duplicata através da técnica de "pour-plate" empregando-se o meio de cultura "plate count agar". As placas foram então incubadas em estufa a $30^{\circ} \mathrm{C}$ por 5 dias. A fim de calcular as unidades formadoras de colônia por grama (UFC/g) de peso seco de sedimento, utilizou-se de $10 \mathrm{~g}$ de sedimento úmido que foi seco em estufa a $60^{\circ} \mathrm{C}$ por 24 horas e em seguida pesado.

\subsection{Enriquecimento e isolamento de bactérias}

O processo de enriquecimento das amostras foi realizado de acordo com Furukawa et al. (1978), através da inoculação de 1,0 g do sedimento em frascos erlenmeyer estéreis contendo $50 \mathrm{~mL}$ de meio mineral mínimo (Zaitsev et al., 1991) acrescido de 0,05\% do poluente a ser pesquisado. No caso do estudo das bactérias degradadoras de PCBs, utilizouse o bifenilo como fonte de carbono para o enriquecimento das amostras e no caso dos hidrocarbonetos, utilizou-se de óleo diesel. Os frascos foram incubados em plataforma de agitação à temperatura de $28^{\circ} \mathrm{C}$ até ser observado crescimento. Então, alíquotas de $100 \mu \mathrm{L}$ foram transferidas para novo frasco contendo meio mineral mínimo acrescido do poluente pesquisado, os quais foram incubados de 1 a 5 dias a $28^{\circ} \mathrm{C}$. Foram realizados três transferências sucessivas nestas condições de cultivo. Na última transferência, foram retiradas 3 alíquotas do consórcio/cultura final para ser estocado em presença de $30 \%$ de glicerol estéril a $-20{ }^{\circ} \mathrm{C}$.

Para o isolamento das bactérias, alíquotas de $100 \mu \mathrm{L}$ de uma cultura obtida a partir do crescimento em meio mineral mínimo acrescido de poluente foram inoculadas em placas 
contendo meio mineral mínimo sólido acrescido do poluente na tampa e incubadas à temperatura de $28^{\circ} \mathrm{C}$. Após obtenção de crescimento, as culturas foram purificadas e estocadas em presença de $30 \%$ de glicerol estéril a $-20{ }^{\circ} \mathrm{C}$.

\subsection{Seleção de diferentes bactérias isoladas através da técnica de BOX-PCR}

Os DNAs genômicos dos isolados dos consórcios foram extraídos e purificados através do kit GFX Genomic blood DNA extraction and purification da Amersham Pharmacia Biotech do Brasil Ltda. Os DNAs obtidos foram submetidas à técnica de sequencia palindrômica repetitiva extragênica de reação em cadeia de polimerase (REPPCR), empregando o iniciador BOX A1R descrito por De Bruijn (1992).

A padronização do PCR para o iniciador BOX A1R foi realizada com alguns isolados. Para a padronização são foram testados os reagentes e concentrações descritos por De Bruijn (1992), Ciapina (1997) e também as condições da técnica tradicional de PCR com as seguintes concentrações finais (tampão $1 \mathrm{X}$; dNTP's - 0,75mM; $\mathrm{MgCl}_{2}-2 \mathrm{mM}$;

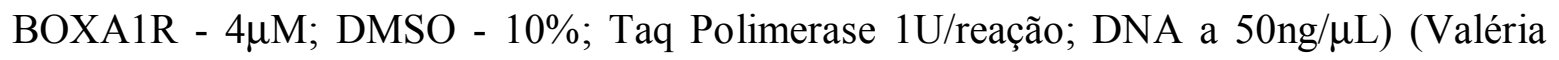
Maia comunicação pessoal). Os melhores resultados foram obtidos pela técnica descrita em De Bruijn (1992) que foi empregada para todos os isolados do presente trabalho.

$\mathrm{Na}$ técnica de De Bruijn (1992), também foram empregadas enzimas Taq polimerase de diferentes fornecedores e verificada as diferenças entre as amplificações e reprodutibilidade para cada uma delas.

As reações de PCR foram padronizadas a partir do protocolo descrito por De Bruijn (1992), em termociclador GeneAmp PCR System 9600 (Perkin-Elmer), compreendendo um ciclo de desnaturação inicial a $94{ }^{\circ} \mathrm{C}$ por 4 minutos, seguido de 35 ciclos de desnaturação a $94{ }^{\circ} \mathrm{C}$ por 1 minuto, anelamento a $55^{\circ} \mathrm{C}$ por 1 minuto e extensão a $72{ }^{\circ} \mathrm{C}$ por 3 minutos, seguido de uma extensão a $72{ }^{\circ} \mathrm{C}$ por 15 minutos, finalizando a $4^{\circ} \mathrm{C}$ por tempo indeterminado.

Os produtos de PCR foram submetidos à separação eletroforética em gel de agarose $1,5 \%(\mathrm{w} / \mathrm{v})$ em tampão TAE. Os padrões de bandas foram visualizados e documentados pelo Eagle Eye Image Analyser após coloração com brometo de etídio $(5 \mu \mathrm{g} / \mathrm{mL})$. Sendo, em seguida, determinados os tamanhos dos fragmentos e comparados entre os perfis 
obtidos para a montagem de uma matriz binária bidimensional, onde 0 indicava a ausência de banda e 1 a presença.

Os padrões de bandas e os grupamentos dos isolados foram realizados pelo programa de Sistema de Análise Multivariada e Taxonomia Numérica (Biostatistical analysis program NTSYS-pc - Applied Biostatistics, Inc.). A similaridade/dissimilaridade genética entre as linhagens foi medida pelo coeficiente de SM (Simple Matching). Este coeficiente considera de mesmo peso as similaridades positivas e negativas no denominador e inclui tanto similaridades negativas, como positivas no numerador. $\mathrm{O}$ dendrograma foi construído pelo método de agrupamento hierárquico UPGMA (Unweighted Pair Group Method with Arithmetic averages) (Nei, 1987), utilizando o programa SAHN (Sequential Agglomerative Hierarchical and Nested Clustering) do NTSYS (Versalovic et al., 1994).

\subsection{Amplificação dos genes catabólicos através da técnica de PCR}

Após a seleção dos isolados que apresentaram padrões de banda diferentes, na técnica do BOX-PCR, foi realizada a amplificação de genes que codificam para as enzimas envolvidas nas vias de degradação dos seguintes compostos: bifenilo (bphA), clorocatecol (tfd C), naftaleno (ndo B), tolueno (tod C1), xileno/catecol (xly E) e C5-C12 n-alcano (alk B). As seqüências de oligonucleotídeos destes genes e as cepas bacterianas utilizadas como controle positivo para cada um destes genes catabólicos, estão descritos na tabela 6 .

As reações de PCR foram padronizadas a partir do protocolo descrito por Whyte et al. (1996) com algumas modificações necessárias para se obter um multiplex PCR, utilizando as seqüências de oligonucleotídeos dos genes catabólicos descritos na tabela 6 . As quantidades de reagentes usados nestas reações de PCR se encontram na tabela 7.

O termociclador empregado foi o GeneAmp PCR System 9600 (Perkin-Elmer), e as condições de amplificação para o Multiplex 1 (contendo os iniciadors tod $\mathrm{C} 1, n d o \mathrm{~B}$ e $x y l \mathrm{E}$ ) utilizaram um ciclo de desnaturação inicial a $95{ }^{\circ} \mathrm{C}$ por 2 minutos, seguido de 30 ciclos de desnaturação a $94{ }^{\circ} \mathrm{C}$ por 1 minuto, anelamento a $60{ }^{\circ} \mathrm{C}$ por 1 minuto e extensão a $72{ }^{\circ} \mathrm{C}$ por 1 minutos, seguido de uma extensão a $72{ }^{\circ} \mathrm{C}$ por 5 minutos, finalizando a $4^{\circ} \mathrm{C}$ por tempo indeterminado. No multiplex 2 (contendo os iniciadors alkB1, tfdC e $b p h \mathrm{~A}$ ), as condições 
de amplificação foram as mesmas do multiplex 1, com variação apenas da temperatura de anelamento, que foi de $56^{\circ} \mathrm{C}$.

Os produtos de PCR foram submetidos a separação eletroforética em gel de agarose $1,5 \%(\mathrm{w} / \mathrm{v})$ em tampão TAE e as bandas foram visualizadas e documentadas por transiluminação UV após coloração com brometo de etídio $(5 \mu \mathrm{g} / \mathrm{mL})$.

Tabela 6. Seqüências de iniciadores e cepas - referências empregadas para cada gene catabólico estudado (Whyte, 1996).

\begin{tabular}{|c|c|c|c|}
\hline $\begin{array}{c}\text { Gene } \\
\text { Catabólico } \\
\end{array}$ & Seqüência (5'a 3') & $\begin{array}{c}\text { Fragment } \\
(\mathbf{p b})\end{array}$ & $\begin{array}{c}\text { Cepas- } \\
\text { Referências } \\
\end{array}$ \\
\hline \multicolumn{4}{|c|}{ Alcano monoxigenase (Smits et al., 1999) } \\
\hline alkB1-F2 & ATC TGG GCG CGT TGG GAT TTG AGC G & \multirow[t]{2}{*}{641} & \multirow{2}{*}{ Rhodococcus sp. Q15 } \\
\hline alkB1-R1 & CGC ATG GTG ATC GCT GTG CCG CTG C & & \\
\hline \multicolumn{4}{|c|}{ Naftaleno dioxigenase ( Kurkela et al., 1988) } \\
\hline$n d o \mathrm{Bb}-\mathrm{f}$ & CAC TCA TGA TAG CCT GAT TCC TGC CCC CGG CG & \multirow[t]{2}{*}{642} & \multirow{2}{*}{$\begin{array}{c}\text { P. putida ATCC } \\
17484\end{array}$} \\
\hline$n d o \mathrm{Be}-\mathrm{r}$ & CCG TCC CAC AAC ACA CCC ATG CCG CTG CCG & & \\
\hline \multicolumn{4}{|c|}{ Tolueno dioxigenase (Zylstra \& Gibson, 1989) } \\
\hline $\operatorname{tod} \mathrm{C} 1-\mathrm{f}$ & CGG GTG GGC TTA CGA CAC CGC CGG CAA TCT & \multirow[t]{2}{*}{560} & \multirow[t]{2}{*}{ P. putida F1 } \\
\hline tod $\mathrm{C} 1-\mathrm{R}$ & TCG AGC CGC GCT CCA CGC TAC CCA GAC GTT & & \\
\hline \multicolumn{4}{|c|}{ Bifenilo-dioxigenase (Laramée et al., 2000) } \\
\hline bphA1-f & TCACCTGCAGCTATCACGGCTGG & \multirow[t]{2}{*}{825} & \multirow{2}{*}{$\begin{array}{c}\text { P. pseudoalcaligenes } \\
\text { KF } 707\end{array}$} \\
\hline bphA4-R & GGA TCT CCA CCC AGT TCT CGC CAT CGT CCT G & & \\
\hline \multicolumn{4}{|c|}{ Clorocatecol - dioxigenase (Perkins et al., 1990) } \\
\hline$t f d \mathrm{C}-\mathrm{f}$ & CTC AAG ACT TAC GAC ACG GAC GAC CAC AAG CC & \multirow[t]{2}{*}{361} & \multirow{2}{*}{$\begin{array}{l}\text { P. cepacia } \\
\text { CSV } 90\end{array}$} \\
\hline tfd C-r & CCT TCG AAG TAG TAC TGC GTG GTC AAC GTT TC & & \\
\hline \multicolumn{4}{|c|}{ Catecol -2,3 - dioxigenase (Nakai et al., 1983) } \\
\hline$x y l \mathrm{~Eb}-\mathrm{f}$ & GTG CAG CTG CGT GTA CTG GAC ATG AGC AAG & \multirow[t]{2}{*}{834} & \multirow{2}{*}{$\begin{array}{c}\text { P. putida } \\
\text { ATCC } 33015 \\
\end{array}$} \\
\hline$x y l$ Ee-f & GCC CAG CTG GTC GGT GGT CCA GGT CAC CGG & & \\
\hline
\end{tabular}

Tabela 7. Reagentes e quantidades de reagentes utilizados na reação de PCR do multiplex

Reagentes multiplex 1 Reagentes multiplex 2 Concentração Final na reação de PCR

\begin{tabular}{llc}
\hline \hline Iniciador $x y l \mathrm{~Eb}-\mathrm{F}$ & Iniciador alkB1-F2 & $0,2 \mu \mathrm{M}$ \\
Iniciador $x y l \mathrm{Ee}-\mathrm{R}$ & Iniciador alkB1-R1 & $0,2 \mu \mathrm{M}$ \\
Iniciador $t o d \mathrm{C} 1-\mathrm{F}$ & Iniciador $t f d \mathrm{C}-\mathrm{f}$ & $0,2 \mu \mathrm{M}$ \\
Iniciador $t o d \mathrm{C} 1-\mathrm{R}$ & Iniciador $t f d \mathrm{C}-\mathrm{r}$ & $0,2 \mu \mathrm{M}$ \\
Iniciador $n d o \mathrm{Bb}-\mathrm{F}$ & Iniciador $b p h \mathrm{~A} 1-\mathrm{f}$ & $0,2 \mu \mathrm{M}$ \\
Iniciador $n d o B e-\mathrm{R}$ & Iniciador $b p h \mathrm{~A} 4-\mathrm{R}$ & $0,2 \mu \mathrm{M}$ \\
Tampão de PCR $10 \mathrm{x}$ & Tampão de PCR $10 \mathrm{x}_{2}$ & $1 \mathrm{X}$ \\
$\mathrm{MgCl}_{2}(50 \mathrm{Mm})$ & $\mathrm{MgCl}_{2}(50 \mathrm{Mm})$ & $3 \mathrm{mM}$ \\
$\mathrm{DMSO}$ & $\mathrm{DMSO}$ & $10 \%$ \\
DNTPs & dNTPs & $400 \mu \mathrm{M}$ \\
$\mathrm{BSA}$ & $\mathrm{BSA}$ & $170 \mu \mathrm{g} / \mathrm{mL}$ \\
Taq polimerase & Taq polimerase & $2,5 \mathrm{U}$ \\
DNA da amostra & DNA da amostra & $50 \mathrm{ng} / \mu \mathrm{L}$ \\
\hline
\end{tabular}




\subsection{Amplificação parcial do gene $16 \mathrm{~S}$ rRNA através da técnica de PCR}

Com o objetivo de padronizar a amplificação do fragmento de 16S rRNA para o posterior seqüenciamento das mesmas e também afim de avaliar se a qualidade do DNA extraído, foi realizado o PCR a partir das seguintes seqüências do gene 16S rDNA descritas em Lane (1991), tabela 8.

As reações de PCR foram preparadas segundo Nogales et al., 2001, com modificações que se encontram descritas na tabela 9.

As condições de amplificação compreenderam um ciclo de desnaturação inicial a 95 ${ }^{\circ} \mathrm{C}$ por 2 minutos, seguido de 30 ciclos de desnaturação a $94{ }^{\circ} \mathrm{C}$ por 1 minuto, anelamento a $55{ }^{\circ} \mathrm{C}$ por 1 minuto e extensão a $72{ }^{\circ} \mathrm{C}$ por 3 minutos, seguido uma extensão a $72{ }^{\circ} \mathrm{C}$ por 3 minutos, finalizando a $4^{\circ} \mathrm{C}$ por tempo indeterminado. Os fragmentos do gene $16 \mathrm{~S}$ rRNA amplificados foram analisados através de corrida eletroforética em gel de agarose a 1,5\% $(w / v)$ em tampão TAE $1 \mathrm{X}$, em seguida foram corados com brometo de etídio $(5 \mu \mathrm{g} / \mathrm{mL})$ e visualizados e documentado por transiluminação UV.

Tabela 8. Iniciadores empregados para a amplificação do gene 16S rRNA

\begin{tabular}{llc}
\hline Iniciadores & \multicolumn{1}{c}{ Seqüência (5'a 3') } & Fragmento (pb) \\
\hline $27 \mathrm{f}$ & AGA GTT TGA TCM TGG CTC AG & 1498 \\
$1525 \mathrm{r}$ & AAG GAG GTG WTC CAR CC & \\
\hline $27 \mathrm{f}$ & AGA GTT TGA TCM TGG CTC AG & 1374 \\
$1401 \mathrm{r}$ & CGG TGT GTA CAA GGC CCG GGA ACG & \\
\hline \multicolumn{2}{l}{$\mathrm{M}=\mathrm{C}: \mathrm{A} ; \mathrm{W}=\mathrm{A}: \mathrm{T} ; \mathrm{R}=\mathrm{A}: \mathrm{G} ;$ Todos $1: 1$} &
\end{tabular}

Fonte: Lane, 1991

Tabela 9. Reagentes e quantidades de reagentes empregados no PCR do 16S rDNA

Reagentes Concentração Final na reação de PCR

\begin{tabular}{lc}
\hline Tampão & $1 \mathrm{X}$ \\
$\mathrm{BSA}$ & $170 \mu \mathrm{g} / \mathrm{mL}$ \\
$\mathrm{MgCl}_{2}(50 \mathrm{Mm})$ & $1,5 \mathrm{mM}$ \\
$\mathrm{dNTP}$ 's & $0,2 \mathrm{Mm}$ \\
Iniciador $27 \mathrm{f}$ & $0,2 \mu \mathrm{M}$ \\
Iniciador $1525 \mathrm{r}$ ou $1401 \mathrm{r}$ & $0,2 \mu \mathrm{M}$ \\
DNA & $50-100 \mathrm{ng}$ \\
Taq Polimerase & $2 \mathrm{U}$ \\
\hline
\end{tabular}




\subsection{Teste de biodegradação de congêneres de PCBs}

\subsubsection{Obtenção e preparo das culturas bacterianas}

Os isolados bacterianos foram inoculados em frascos contendo $100 \mathrm{~mL}$ de meio PAS a pH 7,2 e acrescido de 100mg de cristais bifenilo (Bedard et al., 1986). Em seguida, foram incubados à temperatura de $28^{\circ} \mathrm{C}$, em plataforma de agitação. Após obtenção de uma densidade óptica (D.O.) igual a 1,0 a $615 \eta \mathrm{m}$, todo o crescimento foi filtrado em seringa descartável estéril com lã de vidro, para separação dos cristais de bifenilo e centrifugado a $6.000 \mathrm{rpm}$, à temperatura de $4^{\circ} \mathrm{C}$, durante 10 minutos. As células obtidas foram lavadas duas vezes em tampão fosfato salina (PBS) a 0,05 M, pH 7,5, durante esta manipulação as células foram mantidas em banho de gelo. Foram então ressuspensas no mesmo tampão para obtenção de D.O. igual a 1,0 a $615 \eta \mathrm{m}$. Alíquotas de $1,0 \mathrm{~mL}$ desta suspensão foram distribuídas em 4 tubos de ensaio com tampas de rosca revestidas com papel de alumínio, previamente lavados com acetona (Merck) e autoclavados. Dois tubos foram considerados controles com células mortas e para isso foram levados à temperatura de $100^{\circ} \mathrm{C}$ durante 20 minutos, e resfriados à temperatura ambiente antes da inoculação da mistura dos congêneres. Em seguida, foram adicionados aos 4 tubos de ensaio (duplicata de células vivas e duplicata de células mortas), utilizando uma seringa de vidro Hamilton (previamente lavada 25 vezes com acetona e também lavada 25 vezes entre cada aplicação), $100 \mu \mathrm{L}$ de uma solução estoque $(100 \mathrm{x})$ preparada em acetona (Baker) contendo $5 \mathrm{mM}$ de cada um dos congêneres de PCBs; 4 (PCB 3); 2,4'(PCB 8); 2,4',5 (PCB 31); 2,2',5,5' (PCB 52); 2,2',3',4,5’ (PCB 97); 2,2',4,5,5' (PCB 101) e 2,2',4,4',5,5' (PCB 153) e para obtenção de uma concentração final de $5 \mu \mathrm{M}$ (1 a 2 ppm) na cultura bacteriana. As culturas foram então, incubadas à temperatura de $28^{\circ} \mathrm{C}$, durante 24 horas em plataforma de agitação.

\subsubsection{Extração de PCBs das culturas}

Decorrido o tempo de incubação de 24 horas, a extração dos PCBs foi realizada segundo Bedard et al.(1986). A reação de degradação foi parada pelo aquecimento a $70^{\circ} \mathrm{C}$ por 20 minutos em banho-maria. Foram adicionados então, $400 \mu \mathrm{L}$ de $\mathrm{OCN}^{-}$ 
(Octacloronaftaleno) como controle interno de extração e em seguida foram adicionados 2 $\mathrm{mL}$ de n-hexano. Afim de evitar problemas na separação das fases com o hexano, adicionou-se Triton x-100 (1/10 volume 10\%). Além disso, uma pequena quantidade de sulfato de sódio foi utilizada para a retirada de água da fase a ser analisada no cromatógrafo. Após agitação, a fase superior foi recuperada em tubo de vidro cônico de tampa de vidro esmerilhada com auxílio de pipeta pasteur. O processo foi repetido por 3 vezes. O volume final obtido foi ajustado para $10 \mathrm{~mL}$ e em seguida, foi congelado até a realização das análises cromatográficas. A concentração dos congêneres de PCBs obtidos nas análises foram então, calculados em função do padrão interno recuperado (octacloronaftaleno).

\subsubsection{Análise cromatográfica dos PCBs}

Os PCBs foram analisados em cromatógrafo a gás (GC-ECD), Mac Farren et al. (1970).

Alíquotas de 1,0 $\mathrm{mL}$ foram injetadas em cromatógrafo a gás da marca Hewlett Packard, modelo 5890 série II equipado com um detector de captura de elétrons com fonte de Níquel-63 e com coluna capilar de sílica fundida de $25 \mathrm{~m}$ de comprimento e 0,32 mm de diâmetro interno com fase de 5\% fenil, 95\% metil silicona da J \& W.

A rampa de temperatura da coluna utilizada para a análise cromatográfica foi de $100^{\circ} \mathrm{C}$ (por 1 minuto), $100-250^{\circ} \mathrm{C}\left(5^{\circ} \mathrm{C} /\right.$ minuto), $250-290^{\circ} \mathrm{C} \quad\left(10^{\circ} \mathrm{C} /\right.$ minuto), $290^{\circ} \mathrm{C}$ (1minuto), o tempo total da rampa foi de 40 minutos. $\mathrm{O}$ gás de arraste utilizado foi o $\mathrm{H}_{2}$, com um fluxo na coluna de 2,0 ml.min-1 (6 psi), um fluxo na purga do septo de 3-5 ml.min-1 e um fluxo na purga total de 50 ml.min-1. O gás $\mathrm{N}_{2}$ auxiliar (make-up), possuía um fluxo de $35 \mathrm{ml}$.min-1. A temperatura do injetor e do detector foram respectivamente $275^{\circ} \mathrm{C}$ e $325^{\circ} \mathrm{C}$. A técnica de injeção foi de "splitless"- 60 segundos (Montone, 1995). 


\subsection{Teste de biodegradação de hidrocarbonetos}

\subsubsection{Obtenção e preparo das culturas bacterianas}

Os testes de degradação de hidrocarbonetos foram realizados segundo Whyte et al. (1997) com algumas modificações. As cepas isoladas estocadas a $-20{ }^{\circ} \mathrm{C}$ foram reativadas inoculando em placa de petri contendo meio mineral e óleo diesel, como única fonte de carbono, na tampa. Da placa de petri que foi incubada a uma temperatura de $28{ }^{\circ} \mathrm{C}$, obtevese isolados . Após o crescimento, uma colônia foi selecionada para crescimento em 50mL de caldo triptona soja (TSB) a $28{ }^{\circ} \mathrm{C}$ por 24 horas. Após o crescimento, uma alçadada da cultura foi semeada em placa contendo meio mineral e óleo diesel, a fim de se verificar a ocorrência da perda de atividade de degradação da bactéria. Ao mesmo tempo, o crescimento em caldo TSB foi centrifugado a $11.000 \mathrm{rpm}$ por 20 minutos, sendo o "pellet" lavado duas vezes com meio mineral sem poluente. Ao final da lavagem, o pellet foi ressuspenso em meio mineral a uma densidade óptica igual a 1,0 a $600 \eta \mathrm{m}$. Alíquotas de 1 $\mathrm{mL}$ da suspensão foram colocadas em frascos de headspace de $50 \mathrm{~mL}$, previamente lavados com acetona (Merck) e autoclavados, contendo $4 \mathrm{~mL}$ de meio mineral. Os controles mortos foram fervidos a $100{ }^{\circ} \mathrm{C}$ por 1 hora e resfriados a temperatura ambiente antes da inoculação dos hidrocarbonetos. Em seguida, o frasco foi vedado e foi adicionada à cultura uma mistura de hidrocarbonetos contendo: tolueno, xileno, nonano e naftaleno a uma concentração final de 30ppm em acetona. Para a adição dos poluentes, foi utilizada uma seringa de vidro Hamilton de $250 \mu \mathrm{L}$, previamente lavada 25 vezes com acetona. Foram realizadas triplicatas tanto para as amostras vivas, como para os controles mortos. Após a inoculação do poluente, as culturas foram incubadas à temperatura de $28^{\circ} \mathrm{C}$ por 4 dias em plataforma de agitação. Após a incubação, as cultura foram fervidas a $100^{\circ} \mathrm{C}$ por 30 minutos afim de parar a reação e após o resfriamento o padrão interno (octano) foi adicionado a uma concentração final de 30ppm. 


\subsubsection{Análise cromatográfica dos hidrocarbonetos}

Os hidrocarbonetos foram analisados em cromatógrafo gás (Shimadzu), acoplado ao espectrômetro de massa (GCMS-QP5000/QP5050A) utilizando como gás de arraste o helio (He), pertencente ao Laboratório de Química Fina do Instituto de Química da USP.

Alíquotas de $0,8 \mathrm{~mL}$ foram injetadas no cromatógrafo equipado com coluna capilar de 30 metros com 5\%-phenyl methypolysiloxane (J\&W scientific) e headspace HSS -4A (Shimdzu).

A rampa de temperatura da coluna utilizada para a análise cromatográfica foi de $40^{\circ} \mathrm{C}$ por 2 minutos, $40-65^{\circ} \mathrm{C}\left(3^{\circ} \mathrm{C} /\right.$ minuto), $65-120^{\circ} \mathrm{C}\left(15^{\circ} \mathrm{C} /\right.$ minuto $), 120^{\circ} \mathrm{C}$ (3 minutos), 120 $220^{\circ} \mathrm{C}\left(30^{\circ} \mathrm{C} /\right.$ minuto). O gás de arraste utilizado foi o He, com um fluxo na coluna de $1,3 \mathrm{~mL} \cdot \mathrm{min}^{-1}$. A temperatura do injetor era de $250^{\circ} \mathrm{C}$ e a técnica de injeção foi split (razão 14). Antes de ser injetada a amostra, o frasco de headspace era aquecido por 15 minutos a $80^{\circ} \mathrm{C}$ para a volatilização completa dos poluentes. A análise final foi realizada em relação a curva de calibração dos poluentes e em função da recuperação do padrão interno (octano).

\subsection{Caracterização taxonômica dos isolados}

A identificação dos isolados selecionados foi realizada através de seqüenciamento do gene 16S rRNA. Foram utilizados os primers 27f, 1401r e 1525r para amplificação do 16S rDNA (Lane, 1991) utilizando protocolos anteriormente descritos (Muyzer, 1998 e De Bruijn, 1992).

Os fragmentos de do gene 16S rRNA amplificados foram purificados com o kit GFX PCR DNA and gel band purification da Amersham Pharmacia e sequenciados diretamente no Hemocentro II da UNICAMP.

As seqüências obtidas foram comparadas com seqüências disponíveis nas bases de dados do Genbank (Altschul et al., 1997) disponíveis na Internet. 


\section{RESULTADOS}

\subsection{Caracterização das áreas estudadas}

\subsubsection{Parâmetros físico-químicos}

Os dados de temperatura, salinidade e potencial redox dos pontos amostrados se encontram na tabela 10 .

Tabela 10. Resultados físico-químicos obtidos nos pontos de coletas e nas amostras coletadas

\begin{tabular}{|c|c|c|c|c|c|c|c|c|}
\hline $\begin{array}{c}\text { Pto de } \\
\text { Coleta }\end{array}$ & $\begin{array}{c}\text { Temp. } \\
\mathbf{A r}\end{array}$ & $\begin{array}{c}\text { Temp. } \\
\text { Água }\end{array}$ & $\begin{array}{c}\mathbf{p H} \\
\text { Água }\end{array}$ & $\begin{array}{c}\mathbf{p H} \\
\text { Sedimento }\end{array}$ & Salinidade & $\begin{array}{c}\text { Redox } \\
\text { Água }\end{array}$ & $\begin{array}{c}\text { Redox } \\
\text { Sedimento }\end{array}$ & Profund. \\
\hline 1 & 25,5 & 27,2 & 7,6 & 7,2 & - & $154 \mathrm{mV}$ & $267 \mathrm{mV}(-)$ & $2 \mathrm{~m}$ \\
\hline 2 & 27 & 24,3 & 7,4 & 6,9 & 0,5 & $34 \mathrm{mV}(-)$ & $326 \mathrm{mV}(-)$ & $2,5 \mathrm{~m}$ \\
\hline 3 & 25 & 24,4 & 7,2 & 6,6 & 5,2 & $89 \mathrm{mV}$ & $155 \mathrm{mV}(-)$ & $3,5 \mathrm{~m}$ \\
\hline 4 & 26,5 & 25,3 & 7,7 & 8,2 & 16,9 & $200 \mathrm{mV}$ & $371 \mathrm{mV}(-)$ & $1,3 \mathrm{~m}$ \\
\hline 5 & 27,5 & 27,1 & 7,7 & 6,8 & 24,8 & $129 \mathrm{mV}$ & $102 \mathrm{mV}(-)$ & $1 \mathrm{~m}$ \\
\hline 6 & 26 & 27,9 & 8 & 7,4 & 24,8 & $187 \mathrm{mV}$ & $134 \mathrm{mV}(-)$ & $1 \mathrm{~m}$ \\
\hline 7 & 26,5 & 25 & 6,9 & 6,9 & 14,7 & $150 \mathrm{mV}$ & $153 \mathrm{mV}(-)$ & $1,5 \mathrm{~m}$ \\
\hline 8 & 26,5 & 26 & 6,8 & 6,9 & 11,1 & $72 \mathrm{mV}$ & $351 \mathrm{mV}(-)$ & $1 \mathrm{~m}$ \\
\hline 9 & 26 & 25 & 6,6 & 7,4 & 23,2 & $64 \mathrm{mV}$ & $330 \mathrm{mV}(-)$ & $1 \mathrm{~m}$ \\
\hline
\end{tabular}

Os pontos coletados apresentaram uma salinidade bastante variada. Poderíamos dividir a salinidade do estuário em 3 níveis para os diferentes pontos:

- Salinidade baixa de 0 a $10 \%$ o: pontos 1,2 e 3

- Salinidade média-baixa de 11 a 20\%o: pontos 4,8 e 7

- Salinidade média de 21 a 25\%o: pontos 5, 6 e 9

Em relação a temperatura, tanto da água como do ar, não se observou diferença significativa entre os pontos de coleta, apresentando uma variação entre 25 e $27,9^{\circ} \mathrm{C}$, ocorrendo desta forma, uma variação de no máximo $3^{\circ} \mathrm{C}$ entre alguns pontos.

Já em relação ao potencial redox do sedimento, todos os pontos apresentaram potencial redox negativo, sendo mais negativo o do ponto 4 seguido do potencial redox do ponto 8 . O potencial redox mais alto, isto é, menos negativo, foi o do ponto 5 , seguido do 
ponto 7. Ao contrário do potencial redox medido no sedimento, o da água apresentou todos os potenciais redox positivos, exceto o ponto 2 que apresentou um potencial redox de $-34 \mathrm{mV}$. O potencial redox da água mais alto foi o do ponto 4 , com $200 \mathrm{mV}$.

Os pHs da água oscilaram entre 6,6 e 8. Sendo o ponto 9, com o menor pH e o ponto 6, com o maior. Os pontos que tenderam a acidez, foram os pontos 7, 8 e 9, apesar de possuirem $\mathrm{pHs}$ tendendo a neutralidade ( $\mathrm{pHs}$ bem próximos de 7). Os demais pontos tiveram $\mathrm{pH}$ acima de 7, destacando-se o ponto 3 com um $\mathrm{pH}$ 7,2 que também é um $\mathrm{pH}$ próximo de 7.

Nos sedimentos, os pHs variaram entre 6,6 e 8,2 , sendo o ponto 3 o mais baixo e o ponto 4 o mais alto. Os pontos que tenderam a acidez foram os pontos 2, 3, 5, 7 e 8, os demais pontos tenderam a alcalinidade. A partir destes dados, podemos observar que os pontos 1, 4, 6 apresentaram pHs alcalinos e que os pontos 7 e 8 apresentaram pHs ácidos tanto na água como no sedimento.

Pelos dados, é possível notar que o ponto 4, um dos pontos mais impactados em relação aos demais pontos do estuário, foi o que apresentou as características mais marcantes, com um dos maiores pHs tanto na água como no sedimento, além de apresentar o mais alto potencial redox na água e o mais baixo potencial redox no sedimento em relação aos demais pontos de amostragem.

\subsubsection{Análise granulométrica dos sedimentos}

A granulometria dos sedimentos estudados apresentaram basicamente sedimentos finos, predominando a classe granulométrica "areia" com 56,78\%, sendo a "areia muito fina" a classe mais abundante das amostras analisadas. Enquanto que 36,60\% das amostras apresentaram o "silte", como a segunda classe mais abundante. Mas, no geral, as amostras coletadas no estuário se constituíam predominantemente de areia e pouca argila. Os pontos 2, 4, 5 e 7 apresentaram sedimentos mais finos (tabela 11). 
Tabela 11. Resultados da análise granulométrica dos sedimentos amostrados

\begin{tabular}{|c|c|c|c|c|c|c|c|}
\hline \multirow{2}{*}{$\begin{array}{c}\text { Ponto } \\
\text { de } \\
\text { coleta }\end{array}$} & $\begin{array}{c}\text { Classificação de Shepard } \\
(1954)\end{array}$ & $\begin{array}{c}\% \\
\text { areia }\end{array}$ & $\begin{array}{c}\% \\
\text { silte }\end{array}$ & $\begin{array}{c}\% \\
\text { argila }\end{array}$ & \multicolumn{2}{|c|}{ Diâmetro médio } & $\begin{array}{c}\text { Desvio } \\
\text { Padrão }\end{array}$ \\
\hline 1 & Areia & 89,23 & 10,47 & 0,30 & 2,99 & Areia fina & 0,85 \\
\hline 2 & Silte arenoso & 46,82 & 47,61 & 5,57 & 4,42 & Silte grosso & 1,90 \\
\hline 3 & Silte arenoso & 30,32 & 59,35 & 10,33 & 5,18 & Silte médio & 1,99 \\
\hline 4 & Silte arenoso & 21,12 & 65,97 & 12,91 & 5,82 & Silte médio & 2,05 \\
\hline 5 & Areia síltica & 60,54 & 35,92 & 3,54 & 3,93 & $\begin{array}{c}\text { Areia muito } \\
\text { fina }\end{array}$ & 1,64 \\
\hline 6 & Areia & 75,32 & 22,11 & 2,57 & 3,31 & $\begin{array}{c}\text { Areia muito } \\
\text { fina }\end{array}$ & 1,63 \\
\hline 7 & Silte arenoso & 44,27 & 46,71 & 9,01 & 4,67 & Silte grosso & 2,16 \\
\hline 8 & Areia síltica & 68,76 & 27,53 & 3,71 & 3,28 & $\begin{array}{c}\text { Areia muito } \\
\text { fina }\end{array}$ & 2,11 \\
\hline 9 & Areia & 80,33 & 17,41 & 2,26 & 3,13 & $\begin{array}{c}\text { Areia muito } \\
\text { fina }\end{array}$ & 1,47 \\
\hline
\end{tabular}

\subsubsection{Análise química dos hidrocarbonetos nos sedimentos}

Os resultados dos hidrocarbonetos alifáticos totais e n-alcanos obtidos a partir da análise dos sedimentos estão descritos nas tabela 12 e 13. Foram obtidas concentrações totais de alifáticos variando entre $4,09 \mu \mathrm{g} \cdot \mathrm{g}^{-1}$ e $492,32 \mu \mathrm{g} \cdot \mathrm{g}^{-1}$ nas amostras coletadas.

Pode-se notar que quanto mais longa a cadeia dos alifáticos, maior a sua concentração nos diferentes pontos analisados, exceto nos pontos 2 e 4 que apresentaram maiores concentrações de alifáticos de cadeias mais curtas.

A amostra de sedimento que apresentou as maiores quantidades de n-alcanos e alifáticos totais, foi a do ponto 4 , onde se encontra a COSIPA. Os pontos que apresentaram as menores quantidades de n-alcanos totais e alifáticos totais foram os pontos 1 e 9 respectivamente. Também foi possível notar pelos dados obtidos, que há uma maior quantidade de n-alcanos ímpares em relação aos pares. 


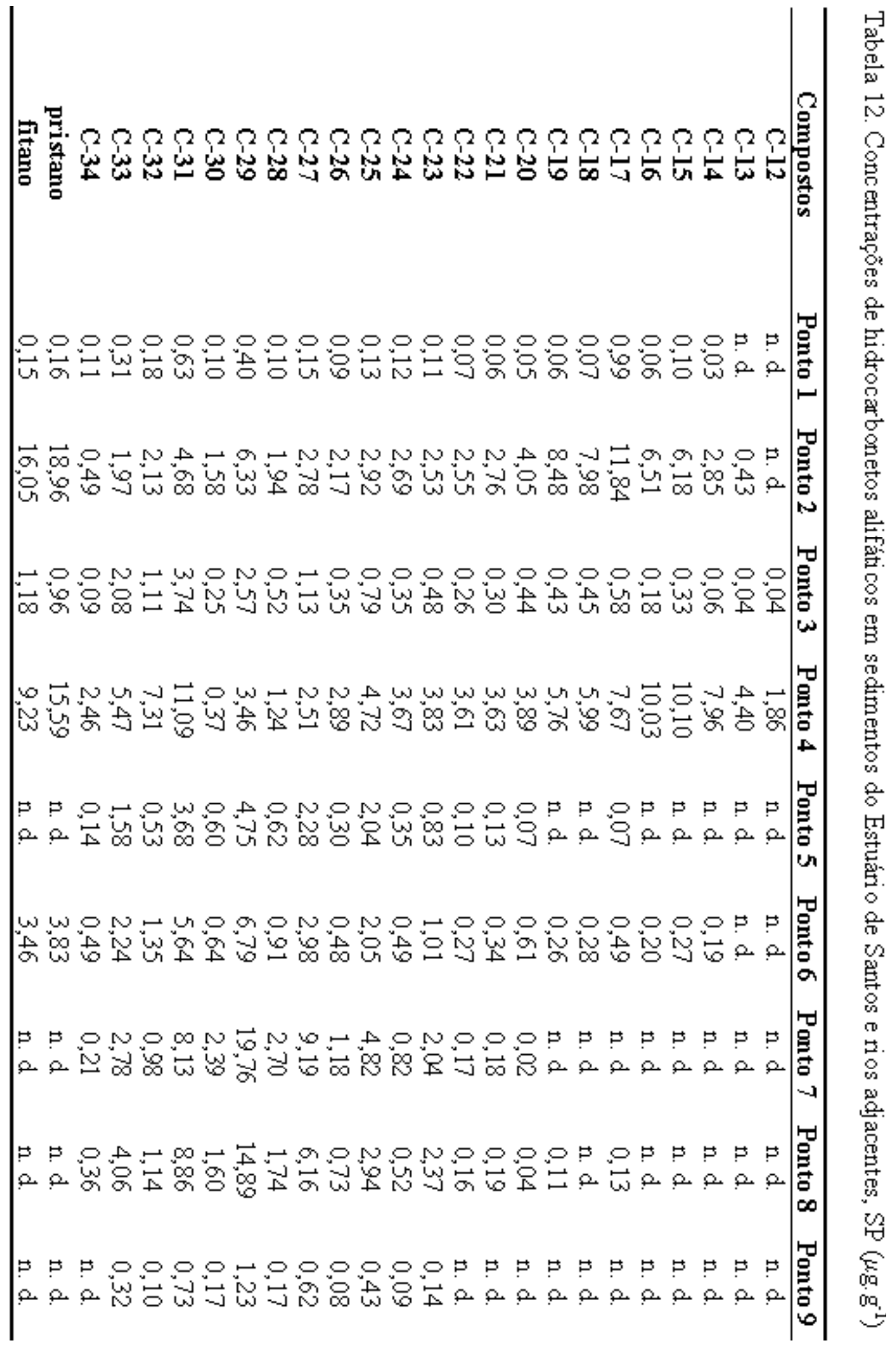




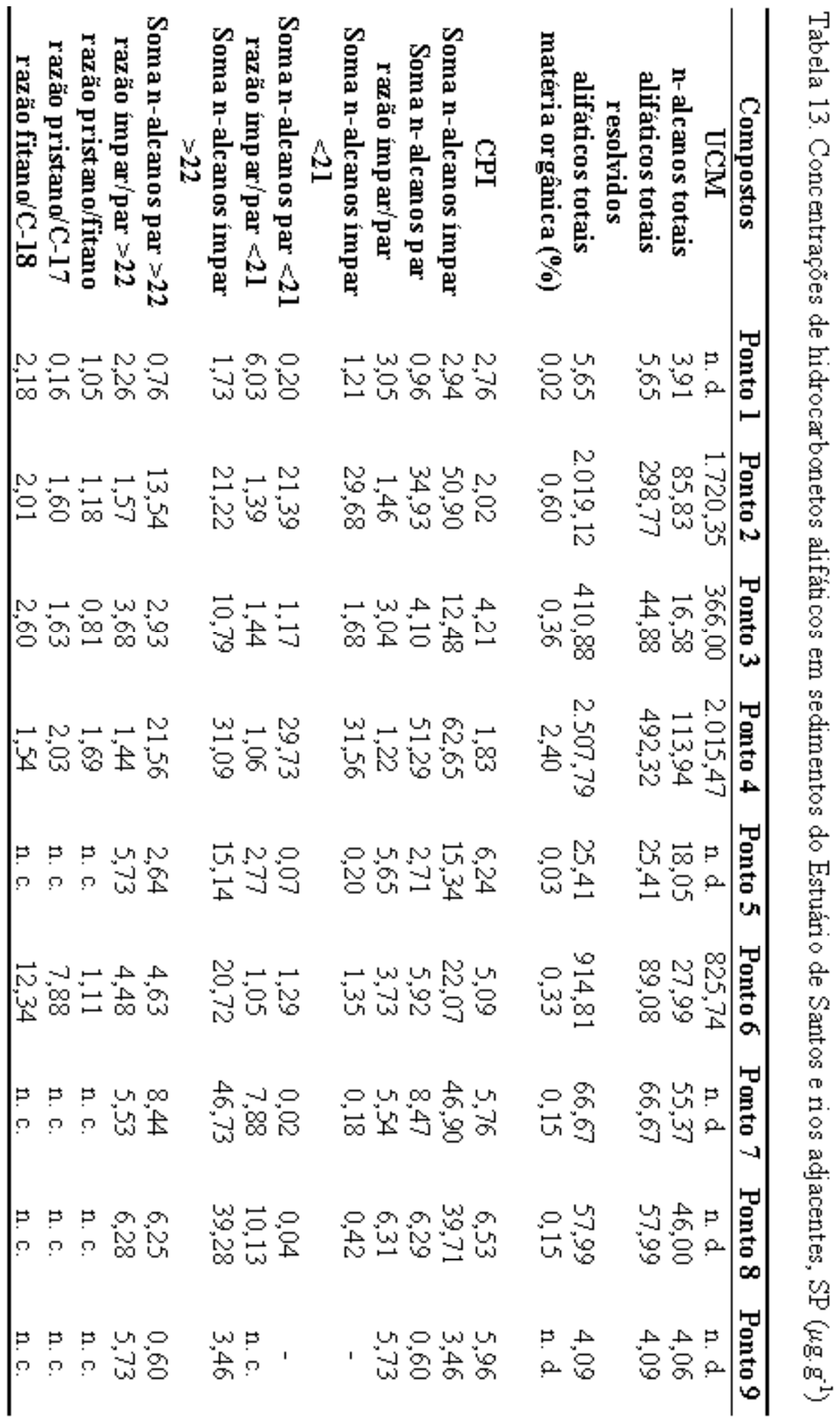


Convém salientar que os n-alcanos totais encontrados, representam muito pouco do total de hidrocarbonetos alifáticos. Grande parte das moléculas que compõem os alifáticos totais são moléculas não resolvidas por cromatografia a gás, constituindo a chamada mistura completa não resolvida (UCM). Esta mistura foi detectada apenas nos pontos 2, 3, 4 e 6, sendo a maior concentração no ponto $4\left(2.015,47 \mu \mathrm{g} \cdot \mathrm{g}^{-1}\right)$ e a menor no ponto 3 (366 $\left.\mu \mathrm{g} \mathrm{g}^{-1}\right)$.

Os isoprenóides pristano $\left(\mathrm{C}_{19}\right)$ e fitano $\left(\mathrm{C}_{20}\right)$ foram encontrados em maior concentração nos pontos 2 e 4. Os pontos, 5, 7, 8 e 9 não apresentaram nenhum destes compostos ou apresentaram baixas concetrações destes compostos.

No caso dos hidrocarbonetos poliaromáticos (PAHs), esses apresentaram concentrações totais variando entre 14 e $407.560 \mu \mathrm{g} \cdot \mathrm{g}^{-1}$. As maiores concentrações ocorreram nos pontos 4, 3 e 2, com 407.560, 47.020 e $1.985 \mu \mathrm{g} . \mathrm{g}^{-1}$ respectivamente e as menores foram detectadas nas amostras dos pontos 9, 8 e 7 com 14, 120 e 150 $\mu \mathrm{g}^{-g^{-1}}$ (tabelas 14 e 15).

Todas as amostras analisadas apresentaram uma predominância de compostos aromáticos policíclicos de 4 a 5 anéis, com excessão do ponto 4 que apresentou uma predominância de compostos com 2 a 3 anéis. 


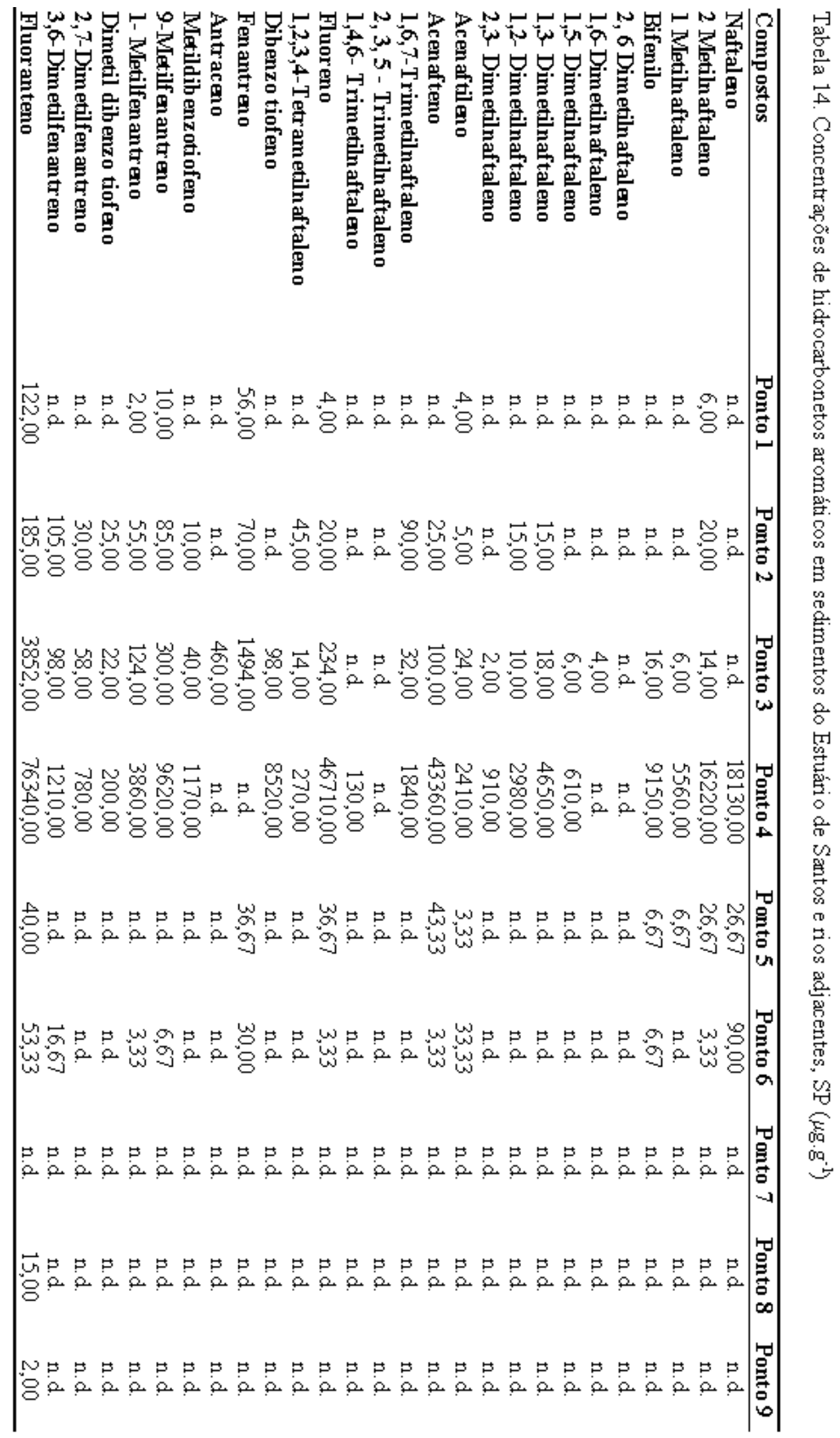




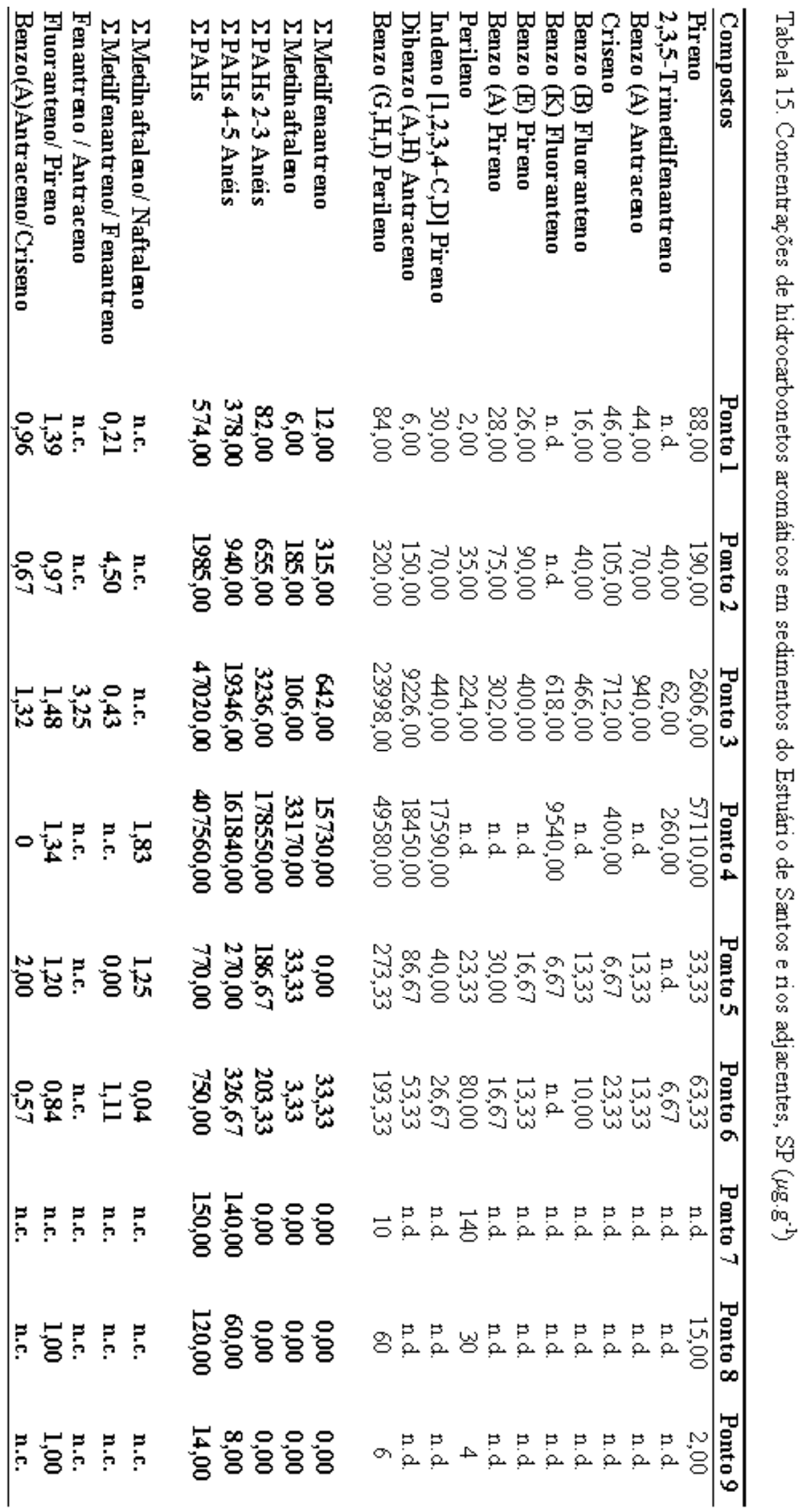




\subsubsection{Análise química dos Bifenilos Policlorados (PCBs) nos sedimentos}

A presença de PCBs foi observada em todas as amostras analisadas (tabela 16). Os níveis de PCBs totais variaram de 0,03 a 253,74 ng.g ${ }^{-1}$, sendo que a maior concentração foi encontrada próxima a COSIPA (ponto 4), e as menores nas amostras 1, 5, 7, 8 e 9.

Foi possível observar a presença de compostos mais pesados nas amostras do sedimento, como pentaclorobifenilos (PCB 101, 110 e 118), hexaclorobifenilos (PCB 138, 149, 151, 153) e heptaclorobifenilos (PCB 170, 180, 183 e 187). Contudo, não foram observados nos pontos analisados nenhum diclorobifenilo (composto leve) ou octaclorobifenilo e nonaclorobifenilo (compostos pesados) (tabela 16). 


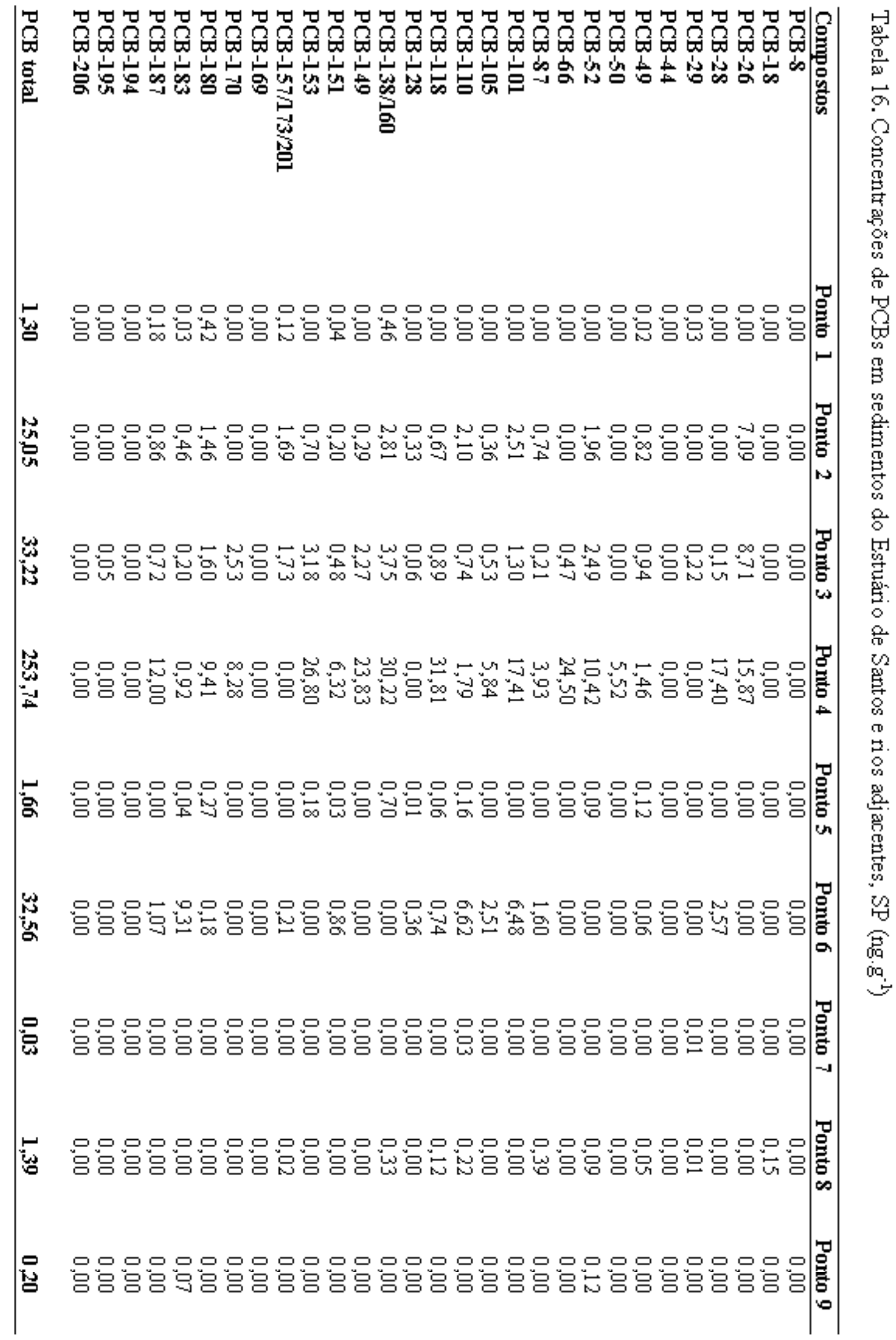




\subsubsection{Correlações das análises granulométricas com os poluentes}

Afim de se correlacionar a presença dos poluentes (hidrocarbonetos e PCBs) nos sedimentos das amostras coletadas, foi realizado o cálculo do coeficiente de correlação linear de Pearson entre as concentrações totais dos poluentes com as porcentagens granulométricas encontradas em cada ponto de coleta. Estes dados estão representados na tabela 17.

Tabela 17. Coeficiente de correlação linear de Pearson entre concentrações totais dos poluentes e matéria orgânica do sedimento e porcentagens granulométricas para os sedimentos coletados no estuário de Santos

\begin{tabular}{c|cccc}
\hline Correlações & Matéria orgânica & \% Areia & \% Silte & \% Argila \\
\hline PCBs totais & 0,99 & $-0,64$ & 0,62 & 0,69 \\
PAHs totais & 0,97 & $-0,64$ & 0,62 & 0,70 \\
Alifáticos totais & 0,86 & $-0,60$ & 0,61 & 0,54 \\
n-alcanos totais & 0,82 & $-0,69$ & 0,69 & 0,67 \\
\hline
\end{tabular}

A partir do cálculo da correlação dos PCBs, hidrocarbonetos aromáticos, alifáticos totais e n-alcanos em relação a matéria orgânica, obtêve-se uma alta correlação destes compostos (correlação acima de 5\%). Demonstrando que a quantidade de matéria orgânica está diretamente relacionada com a retenção dos poluentes no sedimento.

\subsubsection{Contagem de bactérias heterotróficas}

Os resultados obtidos a partir da contagem de heterotróficas estão representadas na tabela 18 .

Os pontos que apresentaram os maiores resultados na contagem de heterotróficas $\left(10^{6} \mathrm{UFC} / \mathrm{g}\right)$ foram os pontos 3 e 4 , sendo que ambos possuem em comum a COSIPA como fator de influência. Os pontos 1 e 9 foram os que apresentaram as menores contagens de heterotróficas, com níveis de até $10^{3} \mathrm{UFC} / \mathrm{g}$. 
Tabela 18. Resultados das contagens de bactérias heterotróficas obtidos nos sedimentos analisados

\begin{tabular}{|c|c|c|}
\hline AMOSTRA & $\begin{array}{c}\text { DATA } \\
\text { COLETA }\end{array}$ & $\begin{array}{c}\text { UFC/g } \\
\text { SEDIMENTO }\end{array}$ \\
\hline Ponto 1 & $10 / 10 / 00$ & $1,0 \times 10^{4}$ \\
\hline Ponto 2 & $03 / 10 / 00$ & $9,0 \times 10^{4}$ \\
\hline Ponto 3 & $03 / 10 / 00$ & $1,5 \times 10^{6}$ \\
\hline Ponto 4 & $03 / 10 / 00$ & $2,2 \times 10^{6}$ \\
\hline Ponto 5 & $17 / 10 / 00$ & $1,2 \times 10^{4}$ \\
\hline Ponto 6 & $17 / 10 / 00$ & $9,6 \times 10^{4}$ \\
\hline Ponto 7 & $27 / 10 / 00$ & $1,0 \times 10^{5}$ \\
\hline Ponto 8 & $27 / 10 / 00$ & $3,3 \times 10^{5}$ \\
\hline Ponto 9 & $27 / 10 / 00$ & $3,7 \times 10^{3}$ \\
\hline
\end{tabular}

$\mathrm{UFC} / \mathrm{g}=$ Unidade formadora de colônia por grama

\subsection{Enriquecimento e isolamento das bactérias}

Foram obtidos consórcios microbianos em todos os pontos de coleta, a partir do enriquecimento utilizando hidrocarbonetos como única fonte de carbono. Um total de 45 isolados foram selecionados a partir dos enriquecimentos em relação a morfologia e coloração da colônia, considerando-se também a coloração de Gram (tabela 19).

No entanto, empregando-se apenas bifenilo, não foram obtidos consórcios nos pontos 2 , 6 e 7. A partir destes consórcios obtêve-se um total de 16 isolados crescidos em bifenilo, com excessão do consórcio do ponto 5 , em que não foi possível isolar bactérias em culturas puras (tabela 19).

$\mathrm{Na}$ coloração de Gram, que foi realizada afim de verificar a pureza dos isolados e caracterizar os mesmos, foi verificado um maior número de bactérias Gram negativas $(95 \%)$. 
Tabela 19. Resultados do número de bactérias isoladas a partir dos consórcios enriquecidos em hidrocarbonetos e bifenilo nos diferentes pontos amostrados.

\begin{tabular}{|c|c|c|c|c|c|}
\hline AMOSTRA & $\begin{array}{c}\text { NÚMERO } \\
\text { TOTAL DE } \\
\text { ISOLADOS }\end{array}$ & $\begin{array}{c}\text { NÚMERO DE } \\
\text { ISOLADOS EM } \\
\text { BIFENILO }\end{array}$ & $\begin{array}{c}\text { NÚMERO DE } \\
\text { ISOLADOS EM } \\
\text { HIDROCARBONETOS }\end{array}$ & \multicolumn{2}{|c|}{} \\
\cline { 4 - 6 } & & & & & GRAM \\
\hline Ponto 1 & 12 & 7 & 5 & 0 & 12 \\
\hline Ponto 2 & 4 & 0 & 4 & 0 & 4 \\
\hline Ponto 3 & 8 & 3 & 5 & 0 & 8 \\
\hline Ponto 4 & 10 & 4 & 6 & 0 & 4 \\
\hline Ponto 5 & 4 & 0 & 4 & 0 & 6 \\
\hline Ponto 6 & 6 & 0 & 6 & 0 & 5 \\
\hline Ponto 7 & 5 & 0 & 5 & 3 & 4 \\
\hline Ponto 8 & 7 & 2 & 5 & 3 & 5 \\
\hline Ponto 9 & 5 & 0 & 45 & & \\
\hline TOTAL DE & 61 & 16 & & & \\
ISOLADOS & & & & & \\
\hline
\end{tabular}

\subsection{Seleção de diferentes bactérias isoladas através da técnica de BOX-PCR}

Os DNAs dos 61 isolados obtidos neste estudo foram submetidos a técnica de BOXPCR. A reprodutibilidade desta técnica foi confirmada realizando-se um mínimo de três repetições para cada isolado. Os resultados obtidos produziram fragmentos de mobilidade aparentemente idênticos, indicando uma boa reprodutibilidade dos mesmos.

No entanto, foi observado que os perfis genômicos obtidos pela técnica de PCR alteravam para o mesmo isolado com a variação dos reagentes e das concentrações dos reagentes nos PCRs, seguindo o protocolo de outras metodologias descritas na literatura. A presente reação de PCR utilizada neste trabalho não apresentou diferenças nos perfis dos DNAs amplificados com a variação de fornecedores da enzima Taq DNA polimerase, confirmando a reprodutibilidade da técnica (Figura 25a). Os resultados obtidos mostraram que o iniciador BOXA1R estavam presentes no genoma das bactérias analisadas. Entretanto, só foi possível obter amplificação de 30 dos 61 DNAs dos isolados analisados.

Os perfis de alguns DNAs amplificados pelo iniciador BOXA1R podem ser observados na figura $25 \mathrm{~b}$. 

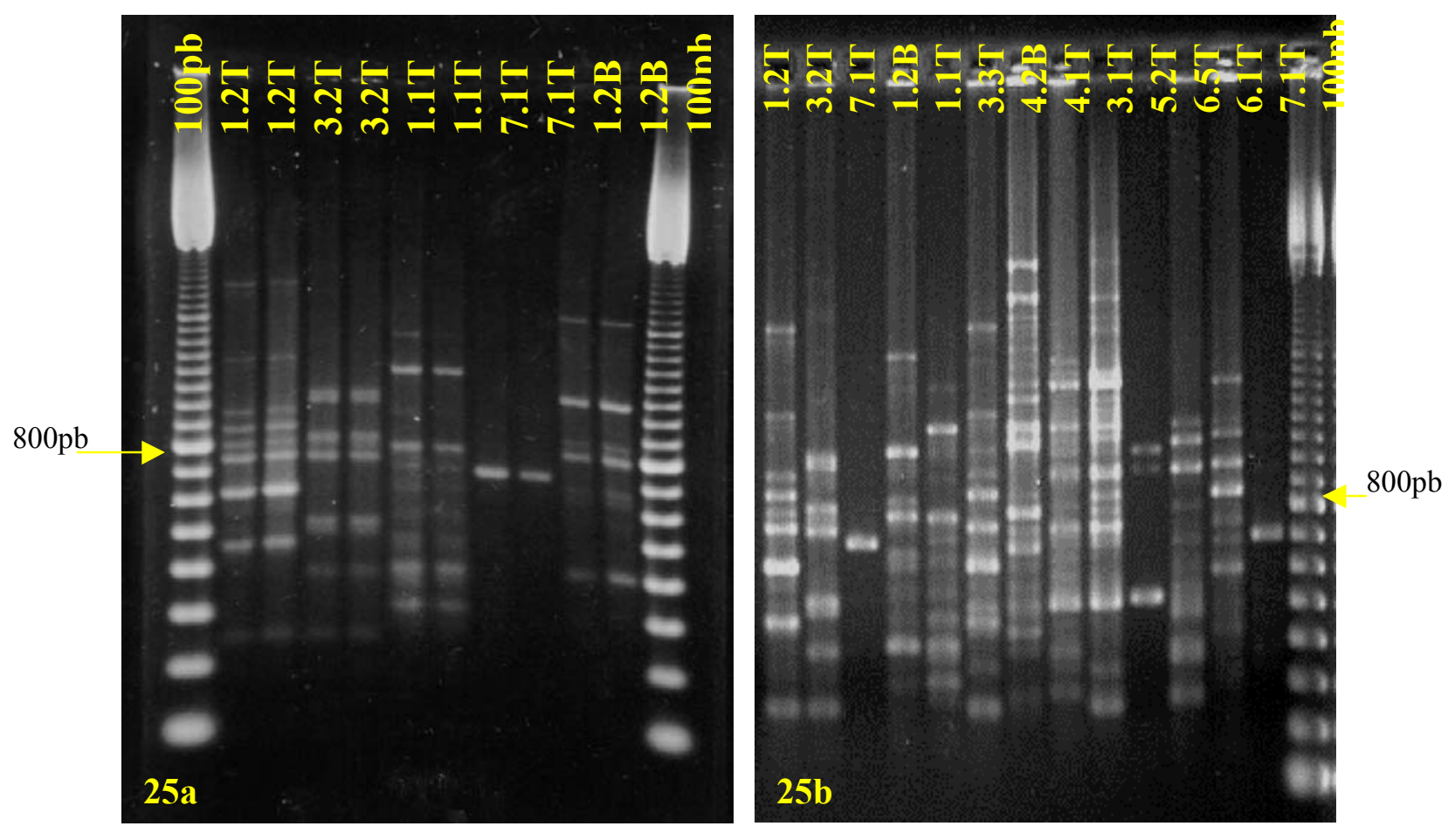

Figuras 25 a, b: Perfis genômicos gerados pela amplificação do iniciador BOXA1R dos DNAs dos isolados. Fotografia de géis de agarose a 1,5\% corado com brometo de etídio com uma corrida de $5 \mathrm{~V} / \mathrm{cm}$. Figura $25 \mathrm{a}$ mostra a reprodutibilidade com Taq DNA Polimerase de 2 diferentes fornecedores (Gibco e Pharmacia) com diferentes isolados. Figura 25b mostra alguns dos diferentes perfis do BOXA1-R obtidos segundo a técnica de De Bruijn (1992). Os isolados do ponto 1 com hidrocarbonetos são: 1.1T-1.2T; isolado do ponto 1 com bifenilo: $1.2 \mathrm{~B}$; isolados do ponto 3 com hidrocarbonetos: $3.1 \mathrm{~T}-3.2 \mathrm{~T}-3.3 \mathrm{~T}$; isolados do ponto 4 com hidrocarboneto e bifenilo respectivamente: $4.1 \mathrm{~T}-4.2 \mathrm{~B}$; isolado do ponto 5 com hidrocarboneto: $5.2 \mathrm{~T}$; isolados do ponto 6 com hidrocarboneto: $6.1 \mathrm{~T}-6.5 \mathrm{~T}$; isolado do ponto 7 com hidrocarbonetos: $7.1 \mathrm{~T}$. 


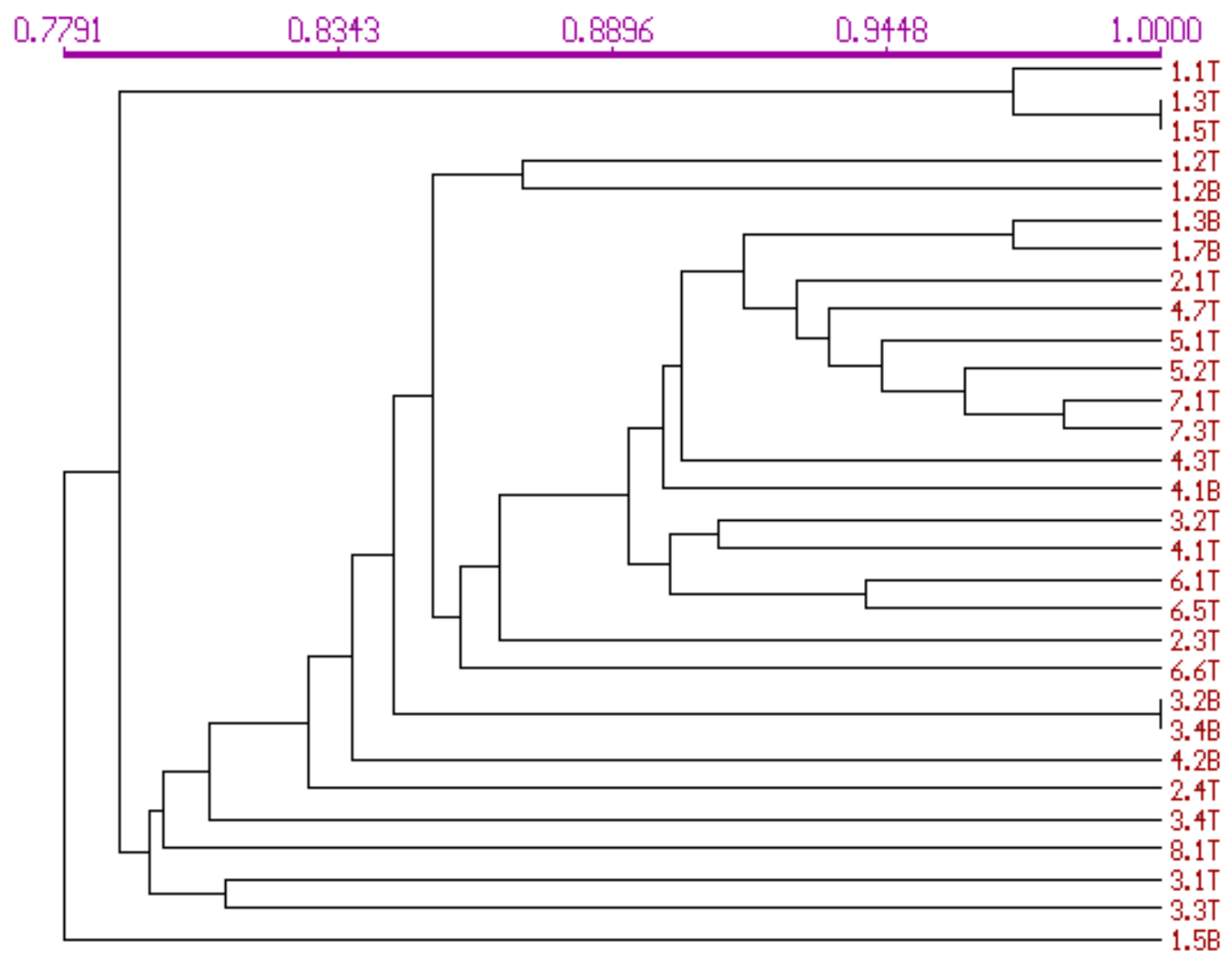

Figura 26: Dendrograma obtido a partir da análise de agrupamentos UPGMA dos perfis genômicos dos isolados bacterianos amplificados pelo BOXA1R

O dendrograma obtido a partir da análise de similaridade dos perfis dos DNAs amplificados pelo BOXA1R se encontra na figura 26. A partir dos 61 isolados obtiveram-se 30 amplificações apresentando 28 padrões de bandas distintos, quando considerado o índice de similaridade de 1,00. Observou-se que as cepas $1.3 \mathrm{~T}$ e $1.5 \mathrm{~T}$, isolados do mesmo ponto de coleta empregando-se hidrocarbonetos como substrato, apresentaram padrões de bandas idênticos entre si, assim como os isolados 3.2B e 3.4B, do mesmo ponto de coleta e enriquecidos em bifenilo. Foram consideradas cepas idênticas, as cepas que apresentavam grau de similaridade 1,00 . 


\subsection{Amplificação dos genes catabólicos através da técnica de PCR}

Os resultados da pesquisa de genes catabólicos, que foram realizadas nos 59 isolados que apresentaram padrões de bandas distintos na análise do BOX-PCR, estão representados nas tabelas nas tabelas 20 e 21 . Os isolados que apresentaram genes catabólicos estão em destaque em vermelho, assim como os genes encontrados nestes isolados.

Através da técnica de PCR dos genes catabólicos, foi possível observar a produção de fragmentos de DNA de tamanho similar aos produzidos pelos controles positivos (figuras $27 \mathrm{a}, \mathrm{b}, \mathrm{c}$ ).

Com relação aos iniciadores específicos para o gene que codifica para a enzima naftaleno dioxigenase (nod B), foi possível observar fragmentos de $642 \mathrm{pb}$ (figura 27) para 3 dos 6 isolados em hidrocarbonetos obtidos a partir do Ponto 4 e em 1 dos 5 isolados em óleo diesel no ponto 3 (tabela 20).

Os genes $t f d \mathrm{C}$ e alk $\mathrm{B}$ que codificam para as enzimas clorocatecol 1,2-dioxigenase e alcano monoxigenase respectivamente, não apresentaram amplificação nos isolados, apenas nas cepas controles (figura 27).

O gene catabólico $x y l$ (Figura 27) que codifica para a enzima 2,3-catecoldioxigenase foi encontrada em isolados crescidos tanto em bifenilo como em hidrocarbonetos. Contudo, entre os genes estudados, o gene $x y l$ E foi o que apresentou o menor número de positividade, apesar deste gene estar disperso no Estuário de Santos, pois foi encontrado nos pontos de amostragem 1, 3, 6 e 8 ao contrário do gene nod $\mathrm{B}$ que só foi encontrado nos pontos de coleta 3 e 4 .

Pôde-se observar pelas tabelas 20 e 21 que o gene tod $\mathrm{C} 1$ foi o gene mais encontrado nos isolados do estuário, pois estava presente tanto em isolados crescidos com bifenilo, como nos isolados crescidos com hidrocarbonetos.

No caso do gene $b p h \mathrm{~A}$, este não foi encontrado em nenhuma das amostras isoladas em hidrocarbonetos, contudo, esteve presente em 6 dos 15 isolados enriquecidos com bifenilo (tabela 21). 
Tabela 20. Resultados obtidos através da técnica de PCR para a pesquisa dos 6 genes catabólicos nos 44 isolados com hidrocarbonetos

\begin{tabular}{|c|c|c|c|c|c|c|c|}
\hline \multicolumn{8}{|c|}{ AMOSTRAS ISOLADAS COM HIDROCARBONETOS } \\
\hline \multirow{2}{*}{$\begin{array}{l}\text { Ponto de } \\
\text { coleta }\end{array}$} & \multirow{2}{*}{$\begin{array}{l}\text { Número do } \\
\text { Isolado }\end{array}$} & \multicolumn{6}{|c|}{ GENES CATABÓLICOS } \\
\hline & & $x y l \mathrm{E}$ & ndo B & tod $\mathrm{C} 1$ & Alk B & $t f d \mathrm{C}$ & bphA \\
\hline \multirow{4}{*}{1} & $1.1 \mathrm{~T}$ & - & - & - & - & - & - \\
\hline & $1.2 \mathrm{~T}$ & - & - & - & - & - & - \\
\hline & $1.4 \mathrm{~T}$ & - & - & - & - & - & - \\
\hline & $1.5 \mathrm{~T}$ & - & - & - & - & - & - \\
\hline \multirow{4}{*}{2} & $2.1 \mathrm{~T}$ & - & - & - & - & - & - \\
\hline & $2.2 \mathrm{~T}$ & - & - & - & - & - & - \\
\hline & $2.3 \mathrm{~T}$ & - & - & - & - & - & - \\
\hline & $2.4 \mathrm{~T}$ & - & - & + & - & - & - \\
\hline \multirow{5}{*}{3} & $3.1 \mathrm{~T}$ & - & - & - & - & - & - \\
\hline & $3.2 \mathrm{~T}$ & - & + & - & - & - & - \\
\hline & $3.3 \mathrm{~T}$ & - & - & - & - & - & - \\
\hline & $3.4 \mathrm{~T}$ & - & - & - & - & - & - \\
\hline & $3.5 \mathrm{~T}$ & - & - & - & - & - & - \\
\hline \multirow{6}{*}{4} & $4.1 \mathrm{~T}$ & - & + & + & - & - & - \\
\hline & $4.3 \mathrm{~T}$ & - & + & + & - & - & - \\
\hline & $4.4 \mathrm{~T}$ & - & + & + & - & - & - \\
\hline & $4.5 \mathrm{~T}$ & - & - & - & - & - & - \\
\hline & $4.6 \mathrm{~T}$ & - & + & + & - & - & - \\
\hline & $4.7 \mathrm{~T}$ & - & - & - & - & - & - \\
\hline \multirow{4}{*}{5} & $5.1 \mathrm{~T}$ & - & - & - & - & - & - \\
\hline & $5.2 \mathrm{~T}$ & - & - & - & - & - & - \\
\hline & $5.3 \mathrm{~T}$ & - & - & - & - & - & - \\
\hline & $5.4 \mathrm{~T}$ & - & - & - & - & - & - \\
\hline \multirow{6}{*}{6} & $6.1 \mathrm{~T}$ & - & - & - & - & - & - \\
\hline & $6.2 \mathrm{~T}$ & - & - & - & - & - & - \\
\hline & $6.3 \mathrm{~T}$ & + & - & - & - & - & - \\
\hline & $6.4 \mathrm{~T}$ & - & - & - & - & - & - \\
\hline & $6.5 \mathrm{~T}$ & - & - & - & - & - & - \\
\hline & $6.6 \mathrm{~T}$ & - & - & - & - & - & - \\
\hline \multirow{5}{*}{7} & $7.1 \mathrm{~T}$ & - & - & - & - & - & - \\
\hline & $7.2 \mathrm{~T}$ & - & - & - & - & - & - \\
\hline & $7.3 \mathrm{~T}$ & - & - & - & - & - & - \\
\hline & $7.4 \mathrm{~T}$ & - & - & - & - & - & - \\
\hline & $7.5 \mathrm{~T}$ & - & - & - & - & - & - \\
\hline \multirow{5}{*}{8} & $8.1 \mathrm{~T}$ & - & - & - & - & - & - \\
\hline & $8.2 \mathrm{~T}$ & - & - & - & - & - & - \\
\hline & $8.3 \mathrm{~T}$ & - & - & - & - & - & - \\
\hline & $8.4 \mathrm{~T}$ & + & - & - & - & - & - \\
\hline & $8.5 \mathrm{~T}$ & - & - & - & - & - & - \\
\hline \multirow{5}{*}{9} & $9.1 \mathrm{~T}$ & - & - & - & - & - & - \\
\hline & $9.2 \mathrm{~T}$ & - & - & - & - & - & - \\
\hline & $9.3 \mathrm{~T}$ & - & - & - & - & - & - \\
\hline & $9.4 \mathrm{~T}$ & - & - & - & - & - & - \\
\hline & $9.5 \mathrm{~T}$ & - & - & - & - & - & - \\
\hline & $=44$ & 2 & 5 & 5 & 0 & 0 & 0 \\
\hline
\end{tabular}

$\mathrm{N}=$ Total de genes catabólicos positivos

Os gene catabólicos $t o d \mathrm{C} 1, n d o \mathrm{~B}, x y l \mathrm{E}, t f d \mathrm{C}$, alk $\mathrm{B}$ e $b p h \mathrm{~A}$, codificam respectivamente para as enzimas tolueno dioxigenase, naftaleno dioxigenase, catecol 2,3-dioxigenase, clorocatecol dioxigenase, alcano monoxigenase e bifenilo dioxigenase. 
A partir dos resultados obtidos também foi possível observar que os pontos 5, 7 e 9 não apresentaram nenhum dos genes estudados. Além disso, os isolados do ponto 4 obtidos em bifenilo também não apresentaram nenhum gene catabólico, diferente dos isolados em hidrocarbonetos. No entanto, os isolados provenientes dos pontos 1,3 e 8 isolados em bifenilo obtiveram maior número de genes do que os isolados em hidrocarbonetos.

Tabela 21. Resultados obtidos através da técnica de PCR para a pesquisa dos 6 genes catabólicos nos 15 isolados com bifenilo

\begin{tabular}{|c|c|c|c|c|c|c|c|}
\hline \multicolumn{8}{|c|}{ AMOSTRAS ISOLADAS COM BIFENILO } \\
\hline \multirow{2}{*}{$\begin{array}{l}\text { Ponto de } \\
\text { coleta }\end{array}$} & \multirow{2}{*}{$\begin{array}{l}\text { Número do } \\
\text { Isolado }\end{array}$} & \multicolumn{6}{|c|}{ GENES CATABÓLICOS } \\
\hline & & $X y l \mathrm{E}$ & ndo B & tod $\mathrm{C} 1$ & alk B & $t f d \mathrm{C}$ & BphA \\
\hline \multirow{7}{*}{1} & $1.1 \mathrm{~B}$ & + & - & + & - & - & - \\
\hline & $1.2 \mathrm{~B}$ & - & - & + & - & - & - \\
\hline & 1.3B & - & - & + & - & - & - \\
\hline & $1.4 \mathrm{~B}$ & - & - & + & - & - & + \\
\hline & $1.5 \mathrm{~B}$ & - & - & + & - & - & - \\
\hline & $1.6 \mathrm{~B}$ & - & - & + & - & - & + \\
\hline & $1.7 \mathrm{~B}$ & - & - & + & - & - & + \\
\hline \multirow[t]{2}{*}{3} & $3.2 \mathrm{~B}$ & + & - & + & - & - & + \\
\hline & $3.3 \mathrm{~B}$ & - & - & - & - & - & - \\
\hline \multirow[t]{4}{*}{4} & $4.1 \mathrm{~B}$ & - & - & - & - & - & - \\
\hline & $4.2 \mathrm{~B}$ & - & - & - & - & - & - \\
\hline & $4.3 \mathrm{~B}$ & - & - & - & - & - & - \\
\hline & $4.5 \mathrm{~B}$ & - & - & - & - & - & - \\
\hline \multirow[t]{2}{*}{8} & 8.1B & - & - & - & - & - & + \\
\hline & $8.5 B$ & - & - & - & - & - & + \\
\hline \multicolumn{2}{|c|}{$\mathrm{N}=15$} & 2 & 0 & 8 & 0 & 0 & 6 \\
\hline
\end{tabular}

$\mathrm{N}=$ Total de genes catabólicos positivos

Os gene catabólicos $t o d \mathrm{C} 1, n d o \mathrm{~B}, x y l \mathrm{E}, t f d \mathrm{C}$, alkB e $b p h \mathrm{~A}$, codificam respectivamente para as enzimas tolueno dioxigenase, naftaleno dioxigenase, catecol 2,3-dioxigenase, clorocatecol dioxigenase, alcano monoxigenase e bifenilo dioxigenase. 

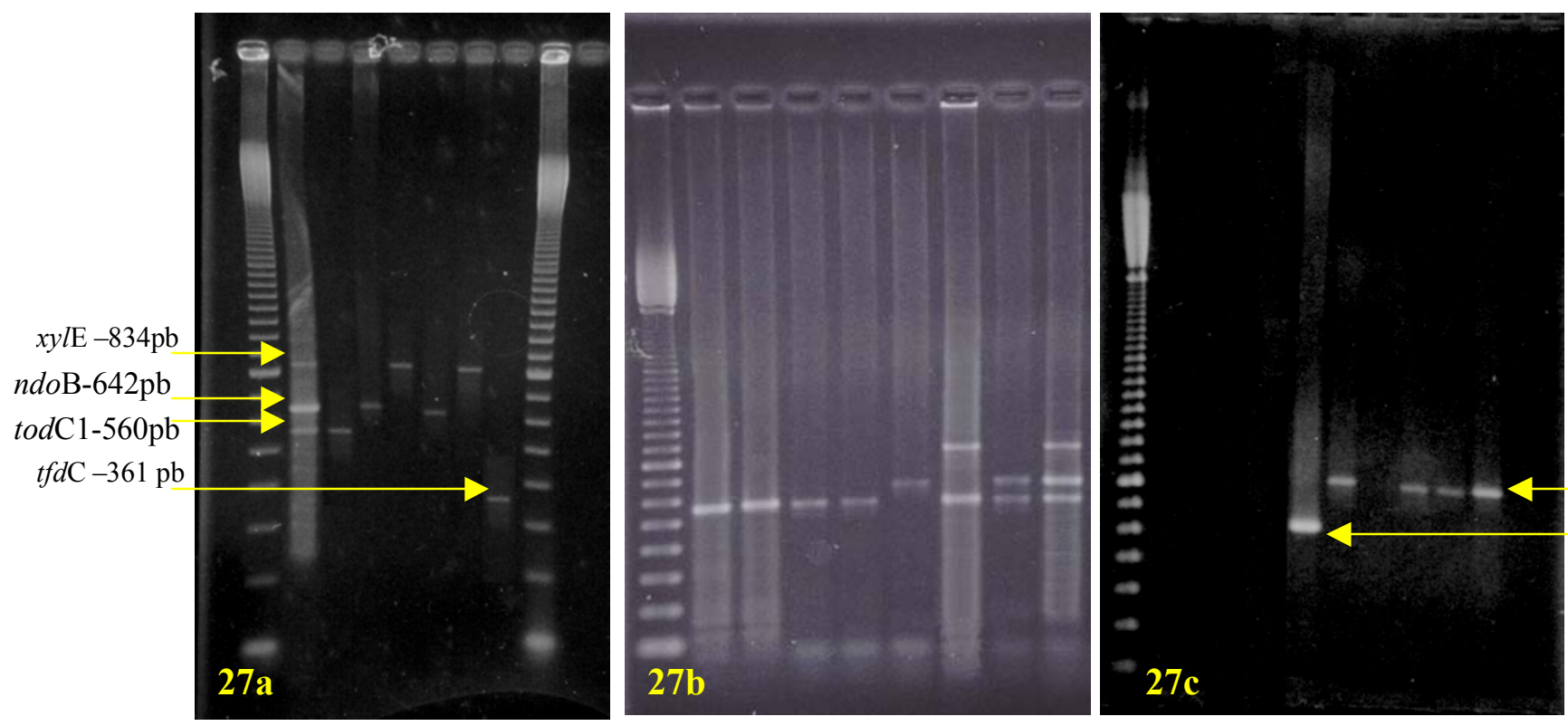

bphA-828pb alkB-641pb

Figura 27 a ,b ,c: Géis de agarose dos resultados dos PCRs dos genes catabólicos mostrando os padrões de bandas dos genes. - Figura 27b:1- Marcador de 100pb; 2- cepa $2.4 \mathrm{~T}$ com gene tod $\mathrm{C} 1$; 3- cepa 1.2B com gene tod $\mathrm{C} 1$; 4- cepa $1.3 \mathrm{~B}$ com gene tod $\mathrm{C} 1$; 5cepa 1.4B com gene tod $\mathrm{C} 1$; 6- cepa 3.2T com o gene $n d o \mathrm{~B}$; 7- cepa 1.1B com os genes $x y l$ $\mathrm{E}$ e $\operatorname{tod} \mathrm{C} 1$; 8- cepa $4.1 \mathrm{~T}$ com os genes $\operatorname{nod} \mathrm{B}$ e $\operatorname{tod} \mathrm{C} 1$; 9- controles positivos com as cepas P. putida F1, ATCC 17484, ATCC 33015, com os genes xyl E, nod B e todC1. Figura 27c: Gel do PCR com algumas amostras: 1- Marcador de 100pb; 2- cepa 4.3T (resultado negativo para o iniciador do gene alkB); 3- cepa 4.3B (resultado negativo para o iniciador do gene alkB); 4- 1.6B (resultado negativo para o iniciador do gene alkB); 5- cepa 3.2B (resultado negativo para o iniciador do gene alkB); 6- Controle positivo para o gene alkB; 7- Controle positivo para o gene $b p h \mathrm{~A} ; 8$ - cepa $5.4 \mathrm{~T}$ (resultado negativo para o iniciador do gene $b p h \mathrm{~A}) ; 9$ - cepa $8.5 \mathrm{~B}($ gene $b p h \mathrm{~A}) ; 10$ - cepa 8.1B (gene $b p h \mathrm{~A}) ; 11$ - cepa 3.2B (gene bphA); 12- Branco (gene bphA)

\subsection{Amplificação parcial do gene 16SrRNA através da técnica de PCR}

A amplificação do fragmento do gene 16SrDNA foi realizado com sucesso em 42 isolados dos consórcios empregando os iniciadores 27f e 1525r. Os 19 restantes foram amplificadas para o gene $16 \mathrm{~S}$ rDNA com os iniciadores $27 \mathrm{f}$ e $1401 \mathrm{r}$. Todas as cepas que foram amplificadas com os iniciadores $27 \mathrm{f}$ e $1525 \mathrm{r}$ apresentaram o mesmo tamanho de banda esperado (1498pb). O mesmo ocorreu para os iniciadores iniciadores $27 \mathrm{f} \mathrm{e} 1401 \mathrm{r}$ que apresentaram 1374pb (Figura 28). 
O fato de diversas cepas, que não amplificaram pelo iniciador BOXA1-R, terem sido amplificadas tanto pelos iniciadores do $16 \mathrm{~S}$ rDNA e/ou por um ou mais iniciadores dos genes catabólicos, demonstraram que não havia nenhum interferente nas amostras de DNA extraídos que justificasse a não amplificação destes DNAs.

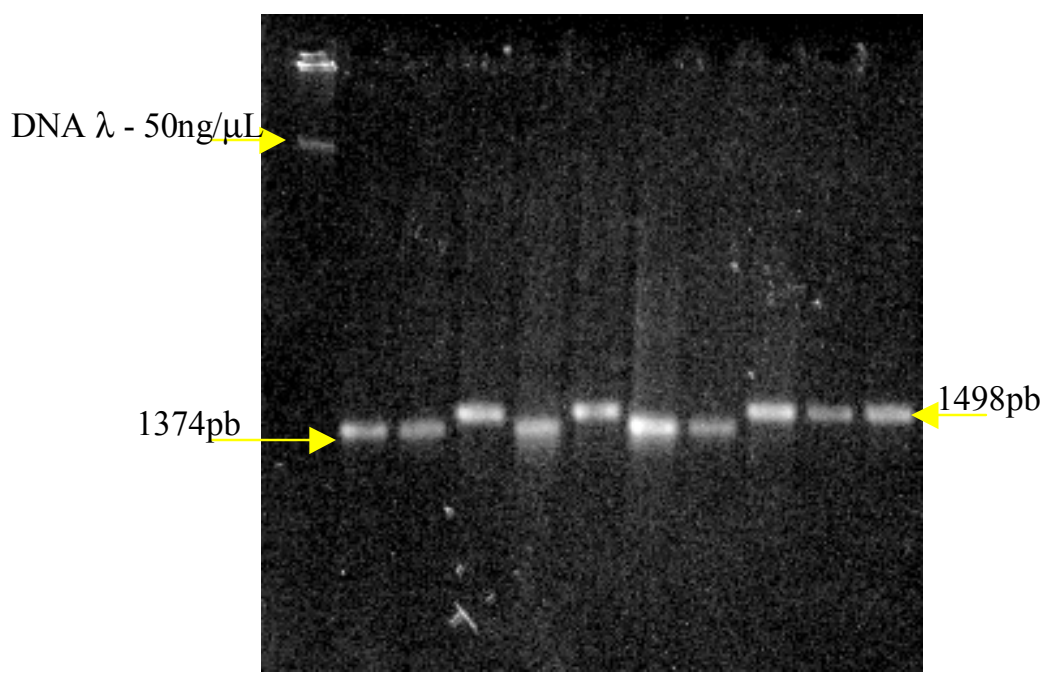

Figura 28: Exemplos de produtos de PCR do gene 16SrRNA em gel de agarose 1\%, corado com brometo de etídio. Estes produtos de PCR foram obtidos a partir dos DNAs de diferentes amostras amplificadas pelos iniciadores $27 \mathrm{f}$ e $1525 \mathrm{r}$, e pelos iniciadores $27 \mathrm{f}$ e $1401 \mathrm{r}$ que produziram bandas com $1498 \mathrm{pb}$ e $1374 \mathrm{pb}$ respectivamente.

\subsection{Teste de biodegradação dos congêneres de PCBs}

O presente teste, foi realizado em 16 dos isolados crescidos em bifenilo que apresentaram padrões de bandas distintos na análise do BOX-PCR. Os resultados obtidos estão apresentados na tabela 22. A ocorrência de redução dos congêneres em taxa abaixo de $20 \%$ não é considerada significativa.

A partir dos dados obtidos podemos notar que o congênere que apresentou melhor degradação (apresentando em alguns casos uma degradação de 100\%) foi o PCB 3, que é o congênere mais leve analisado.

Um congênere importante de salientar é o PCB 153 que é um congênere pesado e que apresentou degradação positiva entre 33 a 30\% para alguns isolados, como o 1.1B, 1.2B, 1.7B, 3.2B e $4.2 \mathrm{~B}$. 
Tabela 22. Porcentagens de degradação dos diferentes congêneres com concentração de $10 \mathrm{ppm}$ pelos diferentes isolados.

\begin{tabular}{|c|c|c|c|c|c|c|c|c|}
\hline \multirow{2}{*}{\multicolumn{2}{|c|}{$\begin{array}{c}\text { Pontos de } \\
\text { amostragem e } \\
\text { números dos } \\
\text { isolados }\end{array}$}} & \multicolumn{7}{|c|}{ I.U.P.A.C. (CONGENERES) } \\
\hline & & \multirow{2}{*}{$\begin{array}{c}\text { PCB } 3 \\
\text { (4) } \\
++\end{array}$} & \multirow{2}{*}{$\begin{array}{c}\text { PCB 8 } \\
\left(2,4^{\prime}\right)\end{array}$} & \multirow{2}{*}{$\begin{array}{c}\text { PCB 31 } \\
(2,4,5)\end{array}$} & \multirow{2}{*}{$\begin{array}{c}\text { PCB 52 } \\
\left(2,2^{\prime}, 5,5^{\prime}\right)\end{array}$} & \multirow{2}{*}{$\begin{array}{c}\begin{array}{c}\text { РCB } 97 \\
\left(2,2^{\prime}, 3^{\prime}, 4,5^{\prime}\right)\end{array} \\
+\end{array}$} & \multirow{2}{*}{$\begin{array}{c}\begin{array}{c}\text { PCB } 101 \\
\left(2,2^{\prime}, 4,5,5^{\prime}\right)\end{array} \\
+\end{array}$} & \multirow{2}{*}{$\begin{array}{c}\text { РCB 153 } \\
\left(2,2^{\prime}, 4,4^{\prime}, 5,5^{\prime}\right) \\
++\end{array}$} \\
\hline \multirow{6}{*}{ Ponto 1} & $1.1 \mathrm{~B}$ & & & & & & & \\
\hline & $1.2 \mathrm{~B}$ & - & - & + & + & + & ++ & ++ \\
\hline & $1.4 \mathrm{~B}$ & ++ & + & + & + & + & + & - \\
\hline & $1.5 B$ & - & - & - & - & - & - & - \\
\hline & $1.6 \mathrm{~B}$ & ++ & + & - & - & - & - & - \\
\hline & 1.7B & + & + & + & + & + & + & + \\
\hline \multirow[t]{2}{*}{ Ponto 3} & 3.2B & ++++ & +++ & + & + & + & + & ++ \\
\hline & 3.3B & ++++ & ++ & - & - & - & - & - \\
\hline \multirow[t]{3}{*}{ Ponto 4} & 4.1B & ++++ & + & + & + & + & + & + \\
\hline & 4.2B & +++ & ++ & ++ & ++ & + & + & + \\
\hline & $4.5 B$ & ++ & + & + & + & + & + & + \\
\hline \multirow[t]{2}{*}{ Ponto 8} & 8.1B & ++++ & ++ & - & - & - & - & - \\
\hline & $8.5 B$ & ++++ & + & - & - & - & - & - \\
\hline
\end{tabular}

Porcentagem de degradação: - <20\%; + 20-39\%;++40-59\%; +++60-79\%; ++++ 80-100\%

Pelos resultados obtidos, os isolados que apresentaram as melhores taxas de degradação foram as cepas $3.2 \mathrm{~B}$ (figura 29) e 4.2B, ambas com altas porcentagens de degradação para diversos congêneres, tanto congêneres leves (PCB 3 e PCB 8) como pesados (PCB 97, PCB101 e PCB153). Os demais isolados, como 1.1B, 1.2B, 3.3B, 4.1B, 8.1B e 8.5B também apresentaram boas taxas de degradação, mas principalmente para congêneres mais leves como o PCB3 e PCB8.

O ponto que apresentou as piores porcentagens de degradação foi o ponto 1. Esse ponto também foi o único que apresentou um isolado que não degradasse nenhum dos congêneres estudados, o isolado 1.5B. No entanto, os isolados apresentaram capacidade de degradação de congêneres pesados como os PCBs 52, 97 e 101. Deve-se ressaltar que os isolados 1.1B e 1.2B, assim como o isolado 3.2B, tiveram capacidade de degradação entre $40-59 \%$ do PCB 153 

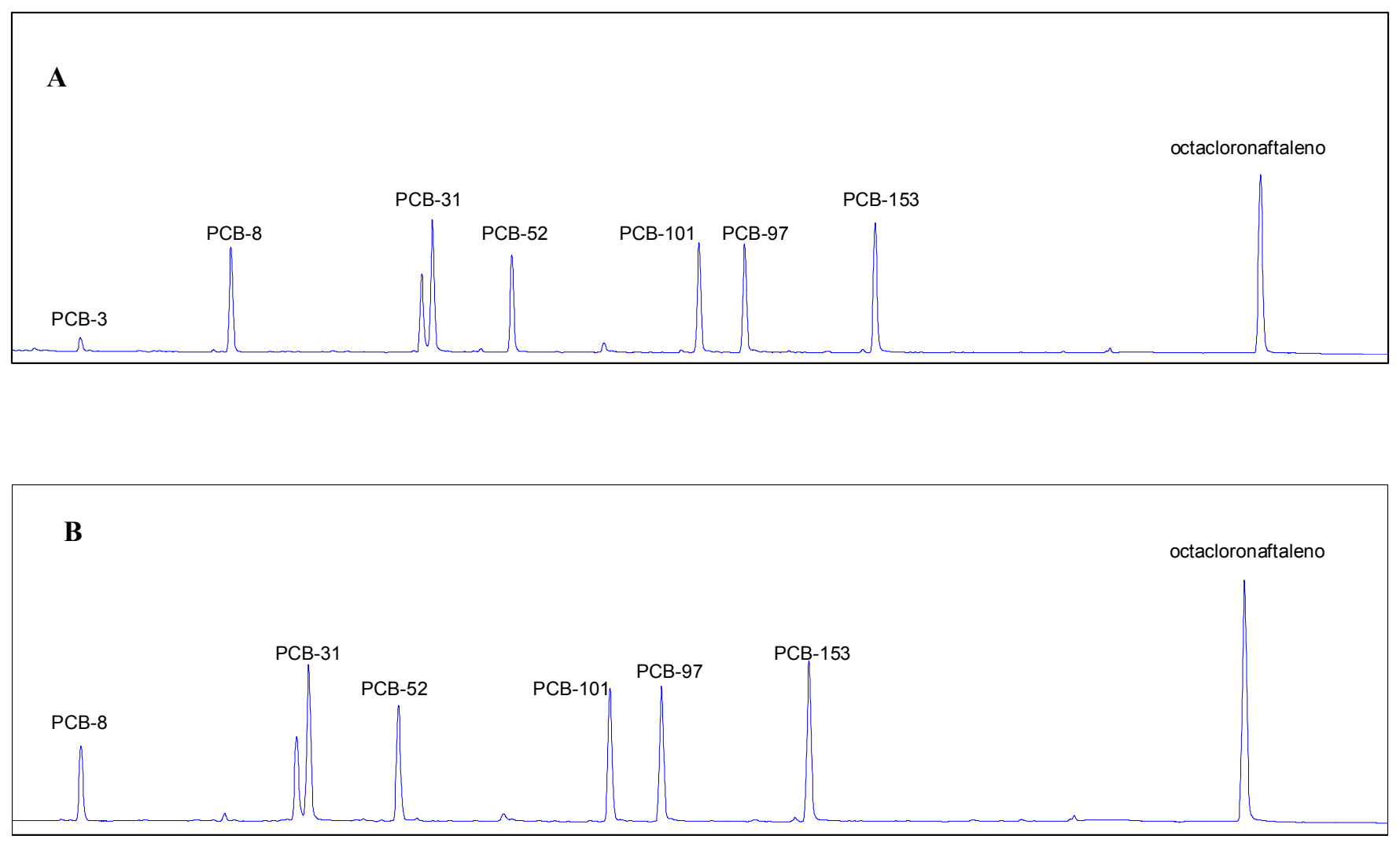

Figura 29: Cromatograma da biodegradação dos diferentes congêneres estudados pelo isolado 3.2B (A, controle bacteriano - células mortas; B- isolado degradador - células com atividade metabólica).

\subsection{Teste de biodegradação de hidrocarbonetos}

Para a realização do teste de biodegradação de hidrocarbonetos foi feita uma triagem inicial dos isolados de hidrocarbonetos que apresentassem diferentes perfís de bandas no PCR utilizando o iniciador BOXA1R. A partir deste dado, foram selecionados 44 isolados de hidrocarbonetos dos 45 obtidos inicialmente. Destes 44 isolados analisados, apenas 40 apresentaram resultados satisfatórios, visto que 4 isolados $(3.5 \mathrm{~T}, 5.3 \mathrm{~T}, 8.3 \mathrm{~T}$ e 9.1T) apresentaram resultados conflitantes nas triplicatas, não sendo possível a análise dos dados.

Este teste de biodegradação de hidrocarbonetos também foi realizado com 7 isolados crescidos em bifenilo que apresentaram os genes catabólicos para o tolueno e/ou 
xileno dioxigenase, afim de se verificar a capacidade destes isolados em degradar tanto PCBs como hidrocarbonetos.

Nos resultados obtidos para os isolados em bifenilo (tabela 23), a degradação foi boa para todos os hidrocarbonetos estudados, principalmente para o nonano e xileno que foram degradados totalmente por 2 dos isolados deste ponto (1.1B e 1.2B).

A partir dos dados da tabela 23, quase todos os isolados apresentaram capacidade de degradar pelo menos um dos hidrocarbonetos estudados, exceto as cepas 2.3T (ponto 2), $6.3 \mathrm{~T}$ e $6.4 \mathrm{~T}$ (ponto 6), que não apresentaram nenhuma capacidade para degradar os compostos estudados.

Os pontos que apresentaram as piores atividades de degradação, foram os pontos $6 \mathrm{e}$ 3. No ponto 6 , dois dos isolados não degradaram nenhum composto, e os demais apresentaram baixa capacidade de degradação para os compostos estudados. No caso do ponto 3, o composto mais degradado foi o naftaleno, contudo a degradação não foi completa, no caso dos demais compostos, a degradação foi pouca ou ausente.

Os dados obtidos, também mostraram que os isolados do ponto 4 foram os que melhor degradaram a maioria dos compostos estudados, com excessão do tolueno, que apesar de ter sido degradado por alguns isolados, a mesma não foi completa. Os pontos $7 \mathrm{e}$ 8 apresentaram excelente capacidade de degradaçao para o xileno e para o nonano. Entretanto, o ponto 1 foi o único que apresentou isolados capazes de degradar completamente o tolueno, além de apresentar o único isolado (1.2T) que degradou completamente todos os compostos analisados.

A partir dos resultados apresentados, pôde-se notar que em relação a capacidade de degradação, a ordem crescente de preferência de degradação pelos compostos foram: o nonano, depois o xileno, seguido do naftaleno e por último o tolueno que foi o menos degradado. 
Tabela 23. Resultados qualitativos do teste de degradação dos hidrocarbonetos xileno, tolueno, nonano e naftaleno pelos isolados do estuário de Santos.

\begin{tabular}{|c|c|c|c|c|c|}
\hline $\begin{array}{c}\text { PONTOS DE } \\
\text { AMOSTRAGEM }\end{array}$ & ISOLADOS & TOLUENO & XILENO & NONANO & NAFTALENO \\
\hline \multirow{4}{*}{$\begin{array}{l}\text { Ponto 1- } \\
\text { Enriquecido com } \\
\text { hidrocarbonetos }\end{array}$} & $1.1 \mathrm{~T}$ & +++ & - & - & + \\
\hline & $1.2 \mathrm{~T}$ & +++ & +++ & +++ & +++ \\
\hline & $1.4 \mathrm{~T}$ & ++ & ++ & +++ & ++ \\
\hline & $1.5 \mathrm{~T}$ & ++ & +++ & +++ & +++ \\
\hline \multirow{4}{*}{$\begin{array}{l}\text { Ponto 2- } \\
\text { Enriquecido com } \\
\text { hidrocarbonetos }\end{array}$} & $2.1 \mathrm{~T}$ & ++ & - & +++ & +++ \\
\hline & $2.2 \mathrm{~T}$ & ++ & ++ & ++ & - \\
\hline & $2.3 \mathrm{~T}$ & - & - & - & - \\
\hline & $2.4 \mathrm{~T}$ & ++ & ++ & ++ & - \\
\hline \multirow{4}{*}{$\begin{array}{l}\text { Ponto 3- } \\
\text { Enriquecido com } \\
\text { hidrocarbonetos }\end{array}$} & $3.1 \mathrm{~T}$ & + & ++ & - & ++ \\
\hline & $3.2 \mathrm{~T}$ & - & + & - & ++ \\
\hline & $3.3 \mathrm{~T}$ & + & + & - & ++ \\
\hline & $3.4 \mathrm{~T}$ & + & + & - & ++ \\
\hline \multirow{6}{*}{$\begin{array}{l}\text { Ponto 4- } \\
\text { Enriquecido com } \\
\text { hidrocarbonetos }\end{array}$} & $4.1 \mathrm{~T}$ & +++ & ++ & +++ & ++ \\
\hline & $4.3 \mathrm{~T}$ & + & +++ & +++ & +++ \\
\hline & $4.4 \mathrm{~T}$ & + & +++ & +++ & +++ \\
\hline & $4.5 \mathrm{~T}$ & ++ & +++ & +++ & +++ \\
\hline & $4.6 \mathrm{~T}$ & ++ & +++ & +++ & +++ \\
\hline & $4.7 \mathrm{~T}$ & - & ++ & ++ & - \\
\hline \multirow{3}{*}{$\begin{array}{c}\text { Ponto 5- } \\
\text { Enriquecido com } \\
\text { hidrocarbonetos }\end{array}$} & $5.1 \mathrm{~T}$ & + & ++ & ++ & + \\
\hline & $5.2 \mathrm{~T}$ & ++ & - & - & - \\
\hline & $5.4 \mathrm{~T}$ & + & + & + & ++ \\
\hline \multirow{6}{*}{$\begin{array}{l}\text { Ponto 6- } \\
\text { Enriquecido com } \\
\text { hidrocarbonetos }\end{array}$} & $6.1 \mathrm{~T}$ & - & + & - & + \\
\hline & $6.2 \mathrm{~T}$ & + & ++ & ++ & ++ \\
\hline & $6.3 \mathrm{~T}$ & - & - & - & - \\
\hline & $6.4 \mathrm{~T}$ & - & - & - & - \\
\hline & $6.5 \mathrm{~T}$ & ++ & +++ & +++ & ++ \\
\hline & $6.6 \mathrm{~T}$ & - & + & ++ & - \\
\hline \multirow{5}{*}{$\begin{array}{l}\text { Ponto } 7- \\
\text { Enriquecido com } \\
\text { hidrocarbonetos }\end{array}$} & $7.1 \mathrm{~T}$ & ++ & ++ & ++ & ++ \\
\hline & $7.2 \mathrm{~T}$ & ++ & +++ & +++ & +++ \\
\hline & $7.3 \mathrm{~T}$ & - & - & + & - \\
\hline & $7.4 \mathrm{~T}$ & + & +++ & +++ & ++ \\
\hline & $7.5 \mathrm{~T}$ & + & +++ & +++ & ++ \\
\hline \multirow{4}{*}{$\begin{array}{l}\text { Ponto 8- } \\
\text { Enriquecido com } \\
\text { hidrocarbonetos }\end{array}$} & $8.1 \mathrm{~T}$ & ++ & +++ & +++ & ++ \\
\hline & $8.2 \mathrm{~T}$ & ++ & +++ & +++ & ++ \\
\hline & $8.4 \mathrm{~T}$ & ++ & ++ & ++ & + \\
\hline & $8.5 \mathrm{~T}$ & + & ++ & ++ & + \\
\hline \multirow{4}{*}{$\begin{array}{l}\text { Ponto 9- } \\
\text { Enriquecido com } \\
\text { hidrocarbonetos }\end{array}$} & $9.2 \mathrm{~T}$ & ++ & +++ & +++ & +++ \\
\hline & $9.3 \mathrm{~T}$ & - & - & + & - \\
\hline & $9.4 \mathrm{~T}$ & + & ++ & + & ++ \\
\hline & $9.5 \mathrm{~T}$ & - & + & + & + \\
\hline \multirow{7}{*}{$\begin{array}{l}\text { Ponto 1- } \\
\text { Enriquecido com } \\
\text { bifenilo }\end{array}$} & $1.1 \mathrm{~B}$ & ++ & +++ & +++ & ++ \\
\hline & $1.2 \mathrm{~B}$ & ++ & +++ & +++ & ++ \\
\hline & $1.3 \mathrm{~B}$ & ++ & ++ & ++ & ++ \\
\hline & $1.4 \mathrm{~B}$ & ++ & ++ & ++ & ++ \\
\hline & $1.5 \mathrm{~B}$ & ++ & ++ & ++ & ++ \\
\hline & $1.6 \mathrm{~B}$ & ++ & ++ & ++ & ++ \\
\hline & $1.7 \mathrm{~B}$ & ++ & ++ & ++ & ++ \\
\hline
\end{tabular}

Taxa de degradação dos hidrocarbonetos: +++ total; ++ alta; + baixa; - não degradou Concentração total de cada hidrocarboneto: $30 \mathrm{ppm}$ 


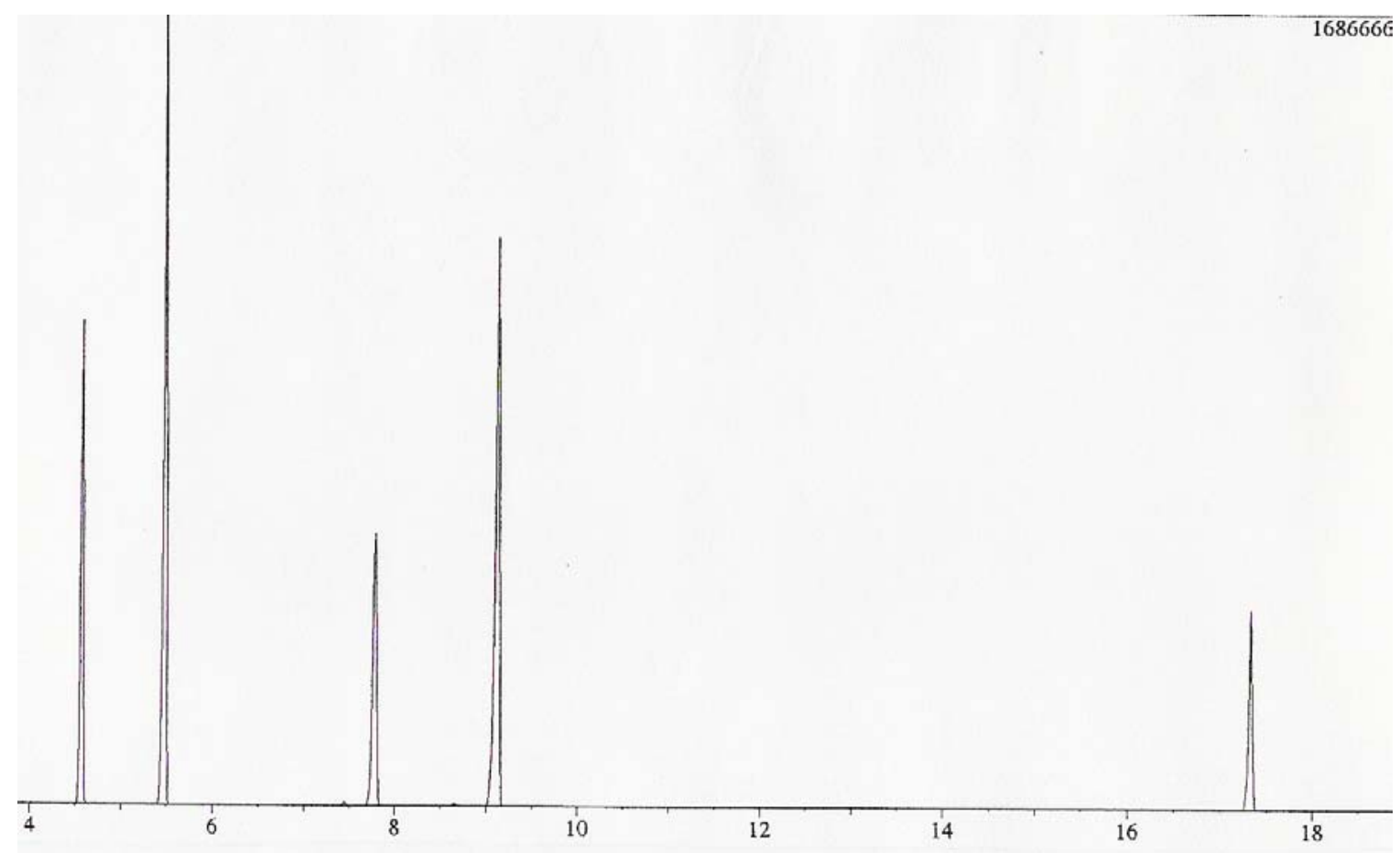

Figura 30: Cromatograma obtido para o padrão empregado no teste de degradação contendo tolueno, octano, xileno, nonano e naftalenona na concentração de $30 \mathrm{ppm}$

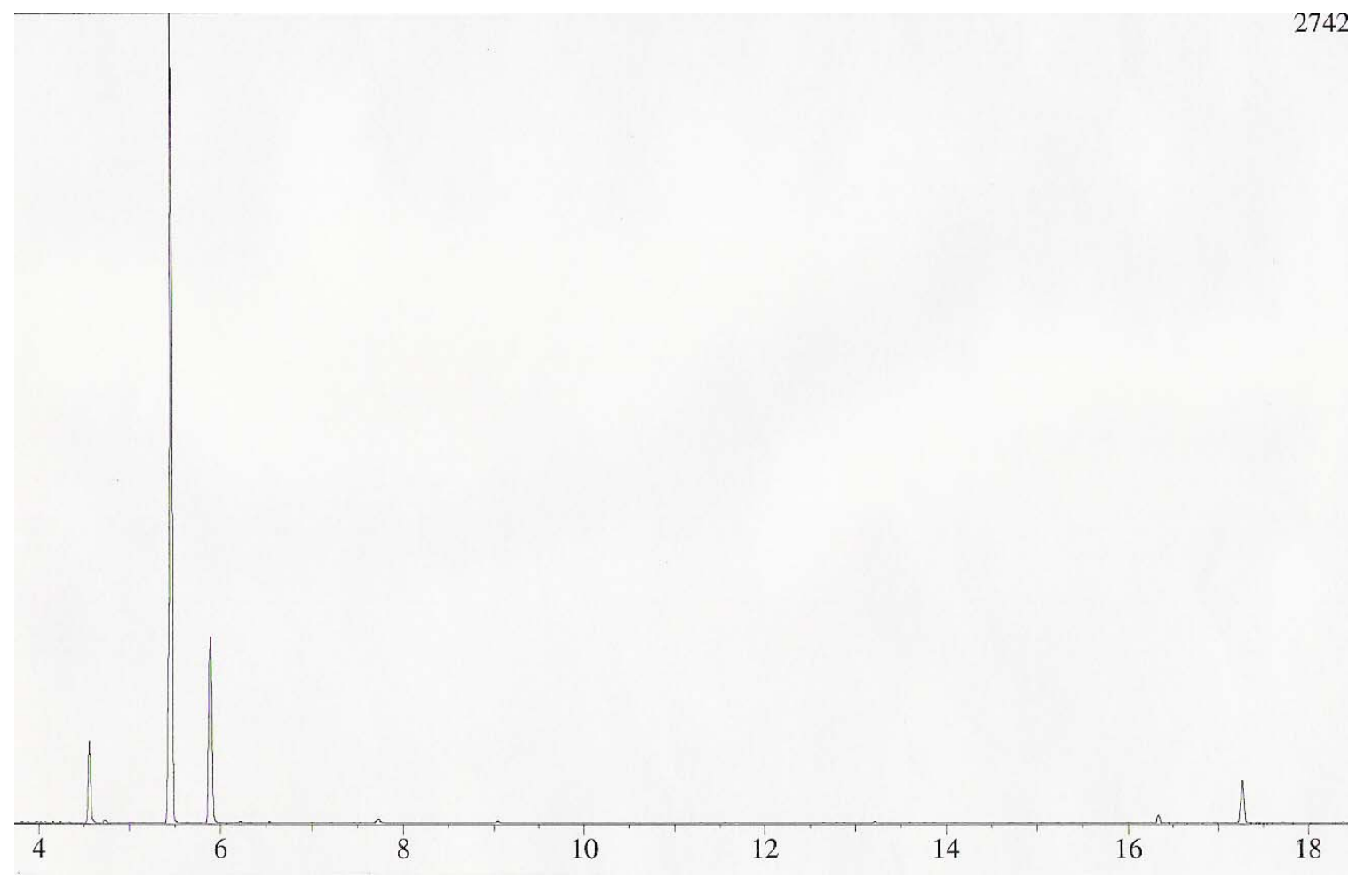

Figura 31: Cromatograma mostrando a degradação dos diferentes hidrocarbonetos estudados pelo isolado $8.1 \mathrm{~T}$. 


\subsection{Caracterização taxonômica dos isolados}

A técnica de seqüênciamento foi realizada para identificar o gênero ou até mesmo a espécie dos isolados obtidos no estuário (tabelas 24 e 25), através da comparação das seqüências estudadas com as seqüências depositadas no Genbank.

Segundo os dados obtidos, podemos notar que há uma predominância do gênero Klebsiella sp. nos isolados estudados (figura 32). Este gênero foi encontrado em todos os pontos de coleta. Contudo este gênero foi mais abundante nos isolados com hidrocarbonetos do que com bifenilo. No caso dos isolados com bifenilo o gênero mais encontrado foi o da Pseudomonas sp., seguido da Agrobacterium sp..

Tabela 24. Resultados do seqüenciamento do gene 16SrRNA de 15 isolados com bifenilo obtidos no estuário de Santos.

\begin{tabular}{|c|c|c|}
\hline Ponto de coleta & Número do isolado & Resultado do seqüênciamento \\
\hline \multirow{7}{*}{1} & $1.1 \mathrm{~B}$ & Pseudomonas sp \\
\hline & $1.2 \mathrm{~B}$ & Pseudomonas sp. \\
\hline & $1.3 \mathrm{~B}$ & Pseudomonas sp. \\
\hline & 1.4B & gamma proteobacteria não cultivável \\
\hline & $1.5 \mathrm{~B}$ & Pseudomonas sp. \\
\hline & $1.6 \mathrm{~B}$ & Pseudomonas sp. \\
\hline & $1.7 \mathrm{~B}$ & Pseudomonas sp. \\
\hline \multirow[t]{2}{*}{3} & $3.2 \mathrm{~B}$ & Agrobacterium larrymoorei \\
\hline & $3.3 \mathrm{~B}$ & Pandoraea $s p$ \\
\hline \multirow{4}{*}{4} & $4.1 \mathrm{~B}$ & Comamonas sp. \\
\hline & $4.2 \mathrm{~B}$ & Klebsiella pneumoniae \\
\hline & $4.3 \mathrm{~B}$ & Agrobacterium larrymoorei \\
\hline & $4.5 \mathrm{~B}$ & Agrobacterium larrymoorei \\
\hline \multirow[t]{2}{*}{8} & $8.1 \mathrm{~B}$ & Rhodococcus sp. \\
\hline & $8.5 \mathrm{~B}$ & Rhodococcus sp. \\
\hline
\end{tabular}


Tabela 25. Resultados do seqüenciamento do gene 16SrRNA de 37 isolados com hidrocarbonetos obtidos no estuário de Santos.

\begin{tabular}{|c|c|c|}
\hline Ponto de coleta & Número do isolado & Resultado do seqüênciamento \\
\hline \multirow{4}{*}{1} & $1.1 \mathrm{~T}$ & Klebsiella pneumoniae \\
\hline & $1.2 \mathrm{~T}$ & Serratia marcescens \\
\hline & $1.4 \mathrm{~T}$ & Klebsiella pneumoniae \\
\hline & $1.5 \mathrm{~T}$ & Klebsiella pneumoniae \\
\hline \multirow{4}{*}{2} & $2.1 \mathrm{~T}$ & Klebsiella sp. \\
\hline & $2.2 \mathrm{~T}$ & Klebsiella pneumoniae \\
\hline & $2.3 \mathrm{~T}$ & Klebsiella pneumoniae \\
\hline & $2.4 \mathrm{~T}$ & Klebsiella ornithinolytica \\
\hline \multirow{3}{*}{3} & $3.1 \mathrm{~T}$ & Klebsiella pneumoniae \\
\hline & $3.4 \mathrm{~T}$ & Klebsiella pneumoniae \\
\hline & $3.5 \mathrm{~T}$ & Serratia marcescens \\
\hline \multirow{6}{*}{4} & $4.1 \mathrm{~T}$ & Klebsiella pneumoniae \\
\hline & $4.3 \mathrm{~T}$ & Pandoraea sp. \\
\hline & $4.4 \mathrm{~T}$ & Calymmatobacterium granulomatis \\
\hline & $4.5 \mathrm{~T}$ & Pandoraea sp. \\
\hline & $4.6 \mathrm{~T}$ & Pandoraea sp. \\
\hline & $4.7 \mathrm{~T}$ & Klebsiella pneumoniae \\
\hline \multirow[t]{2}{*}{5} & $5.1 \mathrm{~T}$ & Klebsiella pneumoniae \\
\hline & $5.4 \mathrm{~T}$ & Serratia marcescens \\
\hline \multirow{5}{*}{6} & $6.2 \mathrm{~T}$ & Klebsiella pneumoniae \\
\hline & $6.3 \mathrm{~T}$ & Pseudomonas putida \\
\hline & $6.4 \mathrm{~T}$ & Acinetobacter sp. \\
\hline & $6.5 \mathrm{~T}$ & Klebsiella pneumoniae \\
\hline & $6.6 \mathrm{~T}$ & Klebsiella pneumoniae \\
\hline \multirow{5}{*}{7} & $7.1 \mathrm{~T}$ & Acinetobacter baumannii \\
\hline & $7.2 \mathrm{~T}$ & Acinetobacter $s p$ \\
\hline & $7.3 \mathrm{~T}$ & Acinetobacter sp. \\
\hline & $7.4 \mathrm{~T}$ & Klebsiella pneumoniae \\
\hline & $7.5 \mathrm{~T}$ & Klebsiella pneumoniae \\
\hline \multirow{4}{*}{8} & $8.1 \mathrm{~T}$ & Klebsiella pneumoniae \\
\hline & $8.2 \mathrm{~T}$ & Staphylococcus sp. \\
\hline & $8.3 \mathrm{~T}$ & Acinetobacter calcoaceticus \\
\hline & $8.4 \mathrm{~T}$ & Agrobacterium larrymoorei \\
\hline \multirow{4}{*}{9} & $9.1 \mathrm{~T}$ & Klebsiella pneumoniae \\
\hline & $9.3 \mathrm{~T}$ & Klebsiella pneumoniae \\
\hline & $9.4 \mathrm{~T}$ & Klebsiella pneumoniae \\
\hline & $9.5 \mathrm{~T}$ & Klebsiella pneumoniae \\
\hline
\end{tabular}




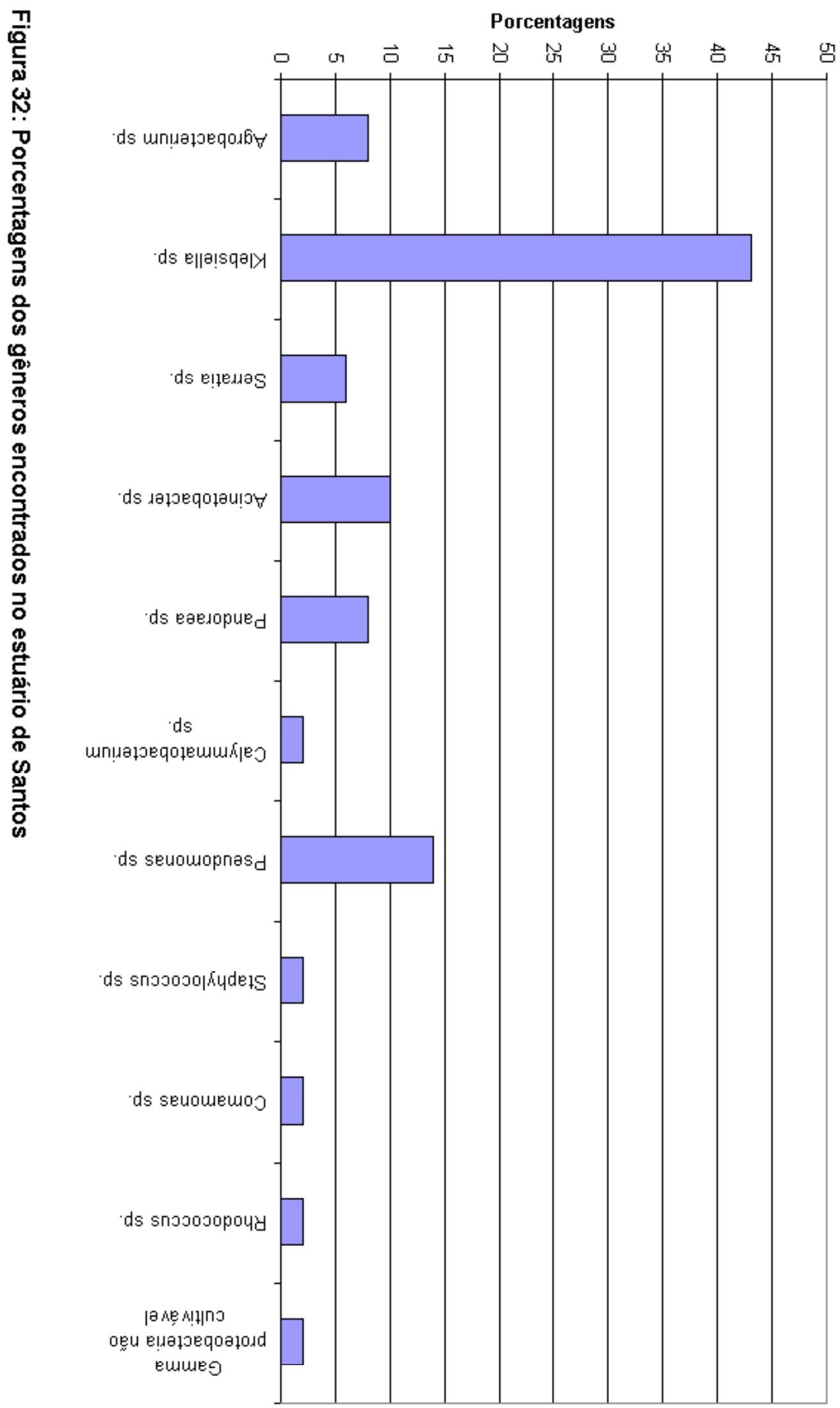




\section{DISCUSSÃO}

\subsection{Caracterização das áreas estudadas}

\subsubsection{Parâmetros físico-químicos}

A análise dos parâmetros físico-químicos de potencial redox (Eh), grau de acidez ou alcalinidade, salinidade e temperatura no momento da coleta tem um importante reflexo ecológico, visto que estes parâmetros são fundamentais para o equilíbrio químico e sobrevivência dos organismos.

A alcalinidade ou acidez de um ambiente exerce um controle muito grande sobre a precipitação de certos minerais, assim como a temperatura condiciona a solubilidade de muitos compostos minerais e de gases. Já a salinidade tem um importante papel na pressão osmótica dos organismos.

No caso da água do mar, esta se encontra com uma salinidade em torno de $35 \%$ o, podendo sofrer alterações quando suprida de água doce e sob condições de temperaturas elevadas que podem ocasionar forte evaporação (Mendes, 1984).

Nas imediações dos grandes estuários, a salinidade tende a ser mais baixa. As águas dos estuários tendem a ser mixo-halinas (Mendes, 1984). Este fato foi observado nas amostras coletadas, visto que todas elas apresentaram salinidade abaixo do normalmente encontrado nos oceanos. Além disso, como era de se esperar, a medida que se coletava amostras nas proximidades do oceano a salinidade aumentava e a medida que se adentrava no estuário a salinidade diminuia. Os pontos 1, 2 e 3 (Rio Cubatão e Rio Piaçaguera) foram os que apresentaram menor salinidade devido a sua localização e ao grande aporte de água doce proveniente dos rios, sendo estes pontos classificados, segundo o relatório da CETESB (2001), como locais de água doce. Os demais pontos com salinidade mais elevada, foram considerados como sendo de água salobra (CETESB, 2001). Os pontos 5, 6 e 9 foram os que tiveram as maiores salinidades em relação aos demais pontos, isto se deu pelo fato de apresentarem suas localizações mais próximas do oceano (figura 22). 
Quanto ao potencial redox, a forma de deposição do sedimento influência nas diferentes características que esse possa adquirir. Em geral, sedimentos depositados sob condições de oxidação significa uma deposição em condições aeróbias; enquanto que sedimentos depositados em condições de redução significa que foi depositado em condições anaeróbias (Mendes, 1984).

Nas amostras coletadas neste estudo (tabela 10), todos os sedimentos apresentaram potencial redutor, enquanto que a maioria dos potenciais redox medidos na água foram oxidantes. Este dado poderia significar que, segundo Mendes (1984), os sedimentos se encontram em condições em que ocorre grande decomposição de materia orgânica e/ou que o sedimento apresenta pouca aeração, o que condiz com os locais de coleta que possuem forte influência de industrias (Pontos 1, 2, 3 e 4) e em alguns casos até de esgoto (Pontos 2 e 8), propiciando a deposição de matéria orgânica no sedimento, e com isto, o aumento da decomposição com conseqüente diminuição da quantidade de oxigênio local, gerando um baixo potencial redox. Além disso, o estuário de Santos é considerado um local de baixa hidrodinâmica, propiciando a deposição de matéria orgânica e poluentes nos sedimentos (Medeiros, 2000). A partir destas informações poderíamos inferir que a baixa hidrodinâmica do estuário dificultaria a mistura e aeração do sedimento, gerando desta forma condições de baixa aeração.

A determinação da temperatura, não variarou muito dentre os diferentes pontos de coleta. Como no trabalho de Bonnetti (2000) as temperaturas encontradas neste estudo estavam em torno de $25^{\circ} \mathrm{C}$.

Os pHs medidos a partir da água, apresentaram uma variação entre 6,5 e 8,0. Nos locais mais internos do estuário, o $\mathrm{pH}$ tendeu mais a neutralidade (variando próximo do $\mathrm{pH}$ 7,0). O único ponto que apresentou $\mathrm{pH}$ mais alcalino (pH8) foi o 6 , provavelmente devido a influência marinha, visto que o $\mathrm{pH}$ dos oceanos se encontra por volta de 8,0, e este é um dos pontos que se encontra próximo a saída da baía.

Os pHs medidos a partir dos sedimentos apresentaram variação semelhante aos $\mathrm{pHs}$ medidos a partir da água, entre 6,6 e 8,2. Mas praticamente todos os sedimentos apresentaram pHs mais baixos ou iguais aos das águas, com excessão dos pontos 4 e 9 (Cosipa e Canal de Barreiros- São Vicente) que apresentaram pHs mais elevados do que os das águas. 


\subsubsection{Análise granulométrica dos sedimentos}

Os resultados obtidos em relação a granulometria do sedimento, corroboram com os dados de Bonnetti (2000), que também encontrou a areia fina como classe predominante no estuário (tabela, 11). Segundo Bonnetti (2000), o predomínio das classes "areia fina" e "silte" demonstra que há um selecionamento granulométrico pobre nas amostras, que é uma característica comum de ambientes de pouca energia, demonstrando que realmente a hidrodinâmica do estuário nesses pontos é baixa. $\mathrm{O}$ fato da hidrodinâmica do estuário ser baixa, propicia a deposição de matéria orgânica, confirmando os baixos dados obtidos de potencial redox nos sedimentos do estuário.

Outro ponto importante de se salientar são os coeficientes de correlação de Pearson (r) obtidos entre a quantidade de matéria orgânica e os poluentes encontrados no estuário, assim como os coeficientes (r) entre os dados granulométricos e os poluentes.

A partir dos dados obtidos, não foi possível obter nenhuma correlação estatística entre os parâmetros sedimentológicos e as concentrações de poluentes, dados também relatados por Medeiros (2000).

Contudo, segundo os dados estatísticos descritos na tabela 17, foi obtido uma alta correlação entre a matéria orgânica e as concentrações totais dos poluentes (valores acima de $80 \%$ ), comprovando que a quantidade de matéria orgânica está diretamente relacionada com a retenção dos poluentes estudados no sedimento.

Portanto, pode-se inferir que a hidrodinâmica do estuário parece não ser eficiente para o transporte dos poluentes estudados até outros locais, permanecendo os mesmos mais concentrados nas proximidades de sua fonte geradora. Desta forma, esses acabam sedimentando e ficando retidos junto a matéria orgânica presente no sedimento do estuário.

\subsubsection{Análise química dos hidrocarbonetos nos sedimentos}

Os resultados dos hidrocarbonetos alifáticos totais e n-alcanos obtidos a partir da análise dos sedimentos se encontram nas tabelas 12 e 13. As concentrações totais de alifáticos encontrados em sedimentos não poluídos apresentam valores variando de $5 \mu \mathrm{g} \cdot \mathrm{g}^{-1}$ (UNEP, 1991; Snedaker et al., 1995; NRC, 1985) a $10 \mu \mathrm{g} . \mathrm{g}^{-1}$ em sedimentos estuarinos e 
até maiores onde há contribuição significativa de plantas superiores (Volkman et al., 1992). No caso dos sedimentos estudados, apenas as amostras dos pontos 1 e 9 apresentaram concentrações inferiores a $10 \mu \mathrm{g} \cdot \mathrm{g}^{-1}$, com 5,65 e 4,09 $\mu \mathrm{g} \cdot \mathrm{g}^{-1}$ respectivamente.

Entretanto, os demais pontos apresentaram concentrações superiores a $10 \mu \mathrm{g} \cdot \mathrm{g}^{-1}$, sendo que as concentrações totais de hidrocarbonetos alifáticos resolvidos nas amostras coletadas variaram entre 4,09 e 492,32 $\mu \mathrm{g} \cdot \mathrm{g}^{-1}$. Intervalos semelhantes e até um pouco menores a este foram encontrados em sedimentos oriundos de outras regiões sob influência de poluição por petróleo, como por exemplo o Canal de São Sebastião, que abriga o maior terminal petrolífero do país. Neste local foram determinadas concentrações de hidrocarbonetos alifáticos totais entre 0,26 e 47,59 $\mu \mathrm{g} \cdot \mathrm{g}^{-1}$ (Bícego, 1996) e um máximo de $51 \mu \mathrm{g} . \mathrm{g}^{-1}$ após um derrame devido ao rompimento de um oleoduto (Zanardi, 1996). O

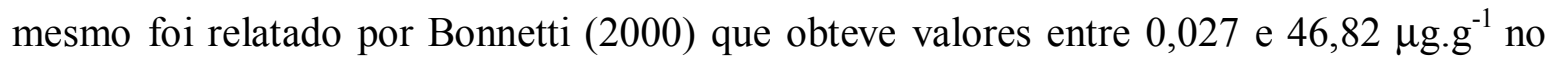
estuário de Santos.

$\mathrm{O}$ índice CPI (índice Preferencial de Carbono) indica o impacto por hidrocarbonetos, considerando a predominância dos compostos n-alcanos de cadeias ímpares sobre os de cadeias pares. Através deste índice é possível verificar a presença de hidrocarbonetos biogênicos. Devido aos resultados obtidos para este índice, foi possível atribuir uma presença dominante de n-alcanos biogênicos, de origem continental, nos pontos $3(4,21), 5(6,24), 6(5,09), 7(5,76), 8(6,53)$ e $9(5,96)$, pois os mesmos apresentaram valores de CPI $>4$, prevalecendo as cadeias carbônicas ímpares superiores a 26 átomos de carbono. Estes pontos foram coletados em locais onde a vegetação de mangues é predominante o que explicaria a prevalência de n-alcanos com alto peso molecular (n- $\mathrm{C}_{23}$ a n- $\mathrm{C}_{33}$ ) de cadeias ímpares que são característicos das ceras cuticulares de plantas superiores (NRC, 1985; Volkman et al., 1992).

Entretanto, valores de CPI em torno de 1 indicam a presença de n-alcanos provenientes de contaminação petrogênica, porque no petróleo normalmente não há predominância de compostos com número par ou ímpar de carbono (NRC, 1985). No caso do nosso estudo, o ponto que apresentou o valor de CPI mais próximo de 1 foi o 4, com CPI de 1,83. As demais amostras apresentaram valores intermediários, indicadores típicos da presença de misturas de n-alcanos de origem biogênica e fóssil, sem predomínio destacado de nenhuma delas. 
Nas amostras do sedimento, também pôde-se observar que quanto maior o tamanho da cadeia de carbonos nos compostos alifáticos, maior era a sua concentração no sedimento coletado. Esta persistência dos n-alcanos de cadeias mais longa provavelmente se justificaria pelo fato dos n-alcanos com cadeias mais curtas serem mais facilmente degradados do que os compostos com cadeias longas ou que os compostos aromáticos (Lynch \& Hobbie, 1988).

O pristano e o fitano, também analisados nos sedimentos, são os isoprenóides mais comumente encontrados na maioria dos sedimentos marinhos, sendo o pristano o mais comum entre os biogênicos, estando presente em várias espécies de zooplâncton (Blumer et al., 1964). O fitano, por sua vez, é raramente biossintetizado, embora possa ser encontrado em algumas bactérias (Han et al., 1969). O estudo destes compostos é importante, visto que os valores de sua razão, serve também como parâmetro para diferenciar a origem dos hidrocarbonetos nos sedimentos.

No presente trabalho a razão pristano/fitano obtidos nos pontos $1,2,3,4$ e 6, a apresentou valores próximos a 1, indicando, segundo Steinhauer \& Boehm (1992), que há presença de componentes de petróleo nas amostras.

No caso das razões pristano/ $\mathrm{C}_{17}$ e fitano/ $\mathrm{C}_{18}$ observou-se valores superiores a $2 \mathrm{em}$ ambos os parâmetros para o ponto 6; nos pontos 1,2 e 3, apenas para o parâmetro fitano/ $\mathrm{C}_{18}$ e no ponto 4 apenas para o parâmetro pristano/ $\mathrm{C}_{17}$. Os valores mais elevados indicam um estágio de degradação mais avançado dos n-alcanos, em vista da preferência dos microrganismos em biodegradarem os compostos lineares em detrimento dos ramificados (Lynch \& Hobbie, 1988).

Outro indicador de presença de contaminação de óleo é dado pela presença de UCM (Mistura Complexa Não Resolvida) (Farrington \& Tripp, 1975). A presença de UCM também é um indicativo de biodegradação dos hidrocarbonetos resolvidos, pois é uma mistura composta basicamente pelos alcanos ramificados, ciclo-alcanos e ciclo-alcanos substituídos que são resistentes a biodegradação e persistentes nos sedimentos (Volkman et al., 1992). As amostras que apresentaram altas concentrações de UCM foram as dos pontos 2, 3, 4 e 6 demonstrando contaminação de hidrocarbonetos de petróleo e degradação dos mesmos nesses pontos. 
No caso das análises dos hidrocarbonetos aromáticos policíclicos (PAHs) foram obtidos valores entre 14 e 407560 ng. $^{-1}$ (tabelas 14 e 15) mostrando que todas as amostras apresentaram concentrações elevadas semelhantes a valores encontrados em regiões poluídas ou que tenham sofrido derramamento de petróleo, como no Golfo Pérsico em 1991 (Maher \& Aislabie, 1992; Burns et al., 1990; Ehrhardt \& Burns, 1993).

$\mathrm{O}$ emprego de razões relativas às proporções entre homólogos não substituídos e alquilados e entre homólogos de mesmo peso molecular, forneceu informações adicionais sobre as fontes antrópicas de PAHs no estuário.

Valores superiores a 1 para as razões entre metilnaftalenos e naftalenos, assim como metilfenantrenos e fenantrenos, verificados nos pontos 2, 4, 5 e 6 indicaram uma origem de hidrocarbonetos policíclicos aromáticos característicos de óleo bruto e derivados nestes locais. Enquanto que os pontos 1 e 3 apresentaram valores inferiores a 1, sugerindo o predomínio de PAHs antrópicos originários de combustão e pirólise.

A origem petrogênica destas amostras foi ratificada através das demais razões calculadas, ou seja, as razões características para o petróleo: fluoranteno/pireno entre $0,6 \mathrm{e}$ 1,4 e o benzo(a)antraceno/criseno entre 0,06 e 0,4 (Gschwend \& Hites, 1981), onde não foram encontradas estas faixas de valores em nenhum dos pontos de amostragem estudados. Pelo fato da maioria das amostras não ter apresentado valores dentro da faixa característica da razão benzo(a)antraceno/criseno, mesmo tendo apresentado valores na faixa entre 0,6 e 1,4 no caso da razão fluoranteno/pireno, sugere que os PAHs encontrados nos pontos amostrados possuem uma origem principalmente pirolítica.

Portanto, apesar dos hidrocarbonetos aromáticos poderem ser sintetizados por alguns fungos, bactérias ou plantas e até mesmo serem liberados dos fundos dos oceanos por fendas naturais, acredita-se que as atividades antropogênicas são as principais responsáveis pelo aporte desses compostos no ambiente marinho (McElroy et al., 1989). A presença destes compostos aromáticos somando-se aos resultados obtidos a partir das análises dos alcanos mostraram que o sedimento da área estuda está realmente impactado por hidrocarbonetos de petróleo. A presença de UMC e os resultados das razões pristano/ $\mathrm{C}_{17}$ e fitano/ $\mathrm{C}_{18}$ no sedimento, também indicaram a possível ocorrência de degradação de hidrocarbonetos no local. 
Como vimos na descrição da área de estudo, esta poluição pode ser advinda tanto de efluentes industriais da COSIPA, Petrobrás, Refinaria presidente Bernardes, como das atividades portuária na região. A contaminação do sedimento do estuário, principalmente no canal do porto, gera muita preocupação. Isto porque, se faz necessária a dragagem periódica do canal devido às atividades portuárias, ressuspendendo contaminantes e transferindo este material para outro local que não está impactado, visto que o sedimento dragado é lançado em mar aberto (quadrante $24^{\circ} 04^{\prime} \mathrm{S}-24^{\circ} 05^{\prime} \mathrm{S} ; 4^{\circ} 18^{\prime} \mathrm{W}-46^{\circ} 19^{\prime} \mathrm{W}$ ). A CETESB, atualmente busca alternativas para o tratamento deste material dragado e está estabelecendo limites de contaminação para sedimentos (CETESB, 2001).

\subsubsection{Análise química dos Bifenilos Policlorados (PCBs) nos sedimentos}

A presença de PCBs foi observada em todas as amostras analisadas (Tabela 16). Os níveis de PCB total variaram de 0,03 a $253,74 \mathrm{ng} \cdot \mathrm{g}^{-1}$ sendo que a maior concentração foi encontrada próxima a COSIPA (ponto 4), e as menores nas amostras 1, 5, 7, 8 e 9 (Cubatão 1, Caneus, Santana, Rio Branco e Barreiros respectivamente). A partir destes dados, podemos dizer que os valores encontrados são comparáveis às regiões remotas, como a Antártica (Montone, 1995), a costa de Alicante na Espanha (Prats, 1992) e menores que os de uma área industrial impactada (Law , 1991).

Contudo, a presença de tetraclorobifenilos (49 e 52), pentaclorobifenilos (110 e 118), hexaclorobifenilos (138 e 151) e heptaclorobifenilos (180 e 183) indica contribuição de misturas comerciais contendo de 40 a $60 \%$ de cloro nas amostras analisadas.

Além disso, nestas amostras foi possível observar uma maior concentração e presença de PCBs que possuem mais que 5 átomos de cloro (PCB-105 a PCB-206) na molécula de bifenilo, podendo indicar que os congêneres mais leves de PCBs possam estar sofrendo biodegradação aeróbia. Este fato se deve a biodegradação de PCBs aeróbia geralmente estar limitada a congêneres que possuem número de cloro igual ou inferior a cinco átomos por molécula de bifenilo, ou seja, os congêneres menos clorados são preferencialmente degradados no ambiente (Bedard et al., 1987 a; Boyle et al., 1992; Hernandez et al., 1992).. 
Contudo, os resultados obtidos mostraram que os sedimentos estudados apresentam baixas concentrações de PCBs, pois nenhum dos valores obtidos se encontram acima de $500 \mathrm{ng} \cdot \mathrm{g}^{-1}$ que caracteriza uma área de alto grau de poluição (Risebrought, 1990). Este resultado poderia ser explicado pelo poder de adsorção e pela alta densidade destes poluentes acrescentado à baixa hidrodinâmica do estuário que dificultariam a distribuição destes compostos no estuário. Desta forma, altos índices de PCBs, provavelmente ocorreriam somente próximos as fontes de contaminação.

\subsubsection{Contagem de bactérias heterotróficas}

A comunidade microbiana presente nos sedimentos tem importante papel na mineralização da matéria orgânica e na degradação dos poluentes. Dessa forma, a caracterização dessa comunidade visa a entender seu papel nesses processos (Rajendran $e t$ al., 1995).

A contagem de bactérias heterotróficas é frequentemente utilizada para indicar a presença ou não de populações bacterianas no ambiente. Contudo, para saber se esta população bacteriana tem algum papel na degradação de determinados poluentes, é necessário fazer uma contagem global de bactérias em meio mínimo com os poluentes pesquisados. A partir desses dados é possível verificar se a presença destes microrganismos está relacionada com a biodegradação dos poluentes, além de verificar a possibilidade de biorremediação no local estudado (Mesarch \& Nies, 1997).

A contagem de heterotróficas é também empregada na caracterização biológica realizada em projetos de biorremediação para verificar se a atividade bacteriana foi afetada pelo poluente e se o número de microrganismos viáveis possibilita a estimulação da atividade microbiana. Os resultados obtidos a partir da contagem de bactérias heterotróficas estão apresentados na tabela 18 . Os pontos que apresentaram os maiores resultados na contagem de heterotróficas $\left(10^{6} \mathrm{UFC} / \mathrm{g}\right)$ foram os pontos 3 e 4 , sendo que ambos possuem em comum efluentes industriais como fator de influência. Os pontos 1 e 9 foram os que apresentaram as menores contagens de heterotróficas, com contagens por volta de $10^{3}$ $\mathrm{UFC} / \mathrm{g}$. Os pontos que apresentaram as menores contagens, também foram os que apresentaram as menores concentrações de alifáticos totais, n-alcanos totais e PCBs totais. 
O ponto que apresentou a maior contagem foi o ponto 4. Este ponto também foi o que apresentou todas as classes de poluentes em maiores concentrações do que os demais pontos.

Segundo Gutberlet (1996), a presença de bactérias heterotróficas nos diversos habitats existente na região do estuário de Santos, independentemente do grau de poluição industrial, possivelmente se deve à adaptação das mesmas aos poluentes industriais que são lançados nesses sedimentos há cerca de três décadas.

Além disso, em vários pontos foram obtidos, valores superiores na contagem de heterotróficas em relação ao trabalho de Bertacini (1998). Em seu trabalho foram realizadas análises de contagem de heterotróficas no estuário de Santos, utilizando a mesma metodologia que foi empregada no presente trabalho, obtendo valores em torno de $10^{2} \mathrm{e}$ $10^{4} \mathrm{UFC} / \mathrm{g}$. Demonstrando que, apesar da presença de poluentes tóxicos (tabelas 12, 13, 14, 15 e 16) no estuário e da mutagenicidade relatada no ponto 4 pela CETESB (2001), as bactérias heterotróficas não parecem apresentar inibição de crescimento bacteriano, pelo contrário, a presença de microrganismos heterotróficos nestes pontos de coleta poderia explicar o baixo potencial redox nos sedimentos, e mesmo na água, de certos locais de coleta (como no ponto 2), pois estes estariam utilizando parte do oxigênio disponível para degradar estes compostos ou outros compostos presentes no local.

Essa situação é freqüentemente encontrada em ecossistemas altamente poluídos, onde os microrganismos utilizam o oxigênio disponível durante os processos de biodegradação (CETESB, 2000). Este fato poderia justificar a presença de um alto número de heterotróficas no ponto 4 e portanto o mais baixo potencial redox, dentre todas as amostras coletadas.

\subsection{Enriquecimento e isolamento de bactérias}

Foram obtidos isolados a partir dos consórcios enriquecidos em hidrocarbonetos (óleo, xileno e naftaleno) e bifenilo. Todos os pontos de coleta enriquecidos em substrato contendo hidrocarbonetos apresentaram crescimento bacteriano, enquanto que apenas os pontos 1, 3, 4, 5, 8 apresentaram crescimento utilizando o bifenilo como substrato (tabela 19). Isto pode ter ocorrido, visto que a molécula do bifenilo é de difícil degradação por ser 
um composto aromático e ter uma estrutura estável, diferente dos compostos derivados de petróleo. Segundo Lynch \& Hobbie (1988), os n-alcanos são um dos compostos mais abundantes no petróleo e são também considerados os compostos mais facilmente degradados por microrganismos, principalmente os de cadeias mais curtas. Além disso, o favorecimento do crescimento de microrganismos em hidrocarbonetos pode ser explicado por este possuir uma variada gama de compostos, tanto aromáticos como alifáticos provenientes de fontes biogênicas ou não, possibilitando, desta maneira, a seleção de diversos microrganismos degradadores de diferentes compostos presentes no óleo.

O fato de se ter encontrado bactérias que utilizam bifenilo no ponto 8 , que não possui contribuição de poluição industrial no estuário de Santos, se deve, provavelmente, à presença de vegetação nos arredores dos locais da coleta. Isto porque, já foram relatados isolamentos de bactérias que degradam bifenilo em diversas amostras ambientais, inclusive em intestino de cupins, sugerindo que bactérias envolvidas no estágio final de degradação de ligninas de plantas possuem enzimas que favorecem a degradação de moléculas de bifenilo. (Kumamaru et al., 1998).

Contudo, foi observado que apesar de ter ocorrido crescimento do consórcio do ponto 5 em bifenilo, não foi possível obter crescimento de isolados em culturas pura. Lynch \& Hobbie (1988) demonstraram que as taxas de crescimento e de utilização de um substrato são, freqüentemente, mais altas em culturas mistas do que em culturas puras isoladas; e segundo Wu (1996), a ausência de sucesso no isolamento de microrganismos degradadores de PCBs pode ocorrer em função do sinergismo das comunidades, ou seja, os microrganismos podem ser dependentes da comunidade para doadores de elétrons, micronutrientes e manutenção de concentrações ótimas de íons hidrogênio. O que poderia justificar o fato de não se ter obtido isolados em alguns pontos em que foi possível obter consórcios degradadores.

A ausência de crescimento nos pontos 2, 6, 7 e 9 no enriquecimento com bifenilo poderia ser explicado pela ausência de um enriquecimento condizente com as condições ambientais encontradas no estuário (tabela 10), como por exemplo a salinidade elevada e um alto potencial redutor encontrado em algumas destas amostras que poderiam estar inibindo o crescimento de microrganismos aeróbios degradadores de PCBs. 
No ponto 2, tanto a água como o sedimento apresentaram um potencial redutor alto, mostrando que o local é de pouca aeração. Considerando-se este fato, os microrganismos que estariam presentes neste local tenderiam a ser ou microaerófilos, anaeróbios ou anaeróbios facultativos. $\mathrm{O}$ fato de não termos obtido crescimento bacteriano poderia ser explicado pela técnica de cultivo empregada voltada para o cultivo de microrganismos degradadores facultativos e aeróbios, excluindo desta forma, os microrganismos anaeróbios que também podem ser degradadores.

No caso do ponto 6 , os fatores ambientais que poderiam estar influenciando no crescimento dos microrganismos são o pH e mesmo a salinidade, visto que o meio utilizado não correspondia à salinidade no ponto de coleta. Considerando que o $\mathrm{pH}$ influencia na atividade enzimática, na solubilidade do oxigênio e na disponibilidade de nutrientes, tais como amônia e fosfato, os quais limitam a taxa de crescimento em muitos ecosssistemas, poderia ser que o $\mathrm{pH}$ utilizado no meio de cultura inibisse o crescimento de bactérias degradadoras pela inativação de suas enzimas e mesmo pela impossibilidade de captação de nutrientes para o crescimento bacteriano.

Nos pontos 5, 6 e 9, outro fator ambiental que poderia estar inflenciando no crescimento microbiano seria a alta salinidade na amostra original. $O$ fato do meio de cultivo não se encontrar na mesma salinidade, poderia de alguma maneira estar influenciando na pressão osmótica destes microrganismos, inibindo o crescimento.

Portanto, a partir dos dados, pudemos observar que os fatores ambientais influenciam na seleção e crescimento bacteriano. Atlas \& Bartha (1987) e Brener (1987), relataram que diversos fatores atuam na recalcitrância e na degradação de um composto, entre eles, ligações entre átomos de carbono e um halogênio, freqüentes em moléculas de compostos xenobióticos e raras em produtos orgânicos naturais, potencial redox, temperatura, variações de $\mathrm{pH}$, disponibilidade da molécula a ser degradada, presença de microrganismos e a interação entre eles, concentração do substrato a ser degradado e de outros nutrientes, além da utilização preferencial por outros substratos. 


\subsection{Seleção de diferentes bactéria isoladas através da técnica de BOX-PCR}

Os DNAs dos 61 isolados foram submetidos a técnica de BOX-PCR. A reprodutibilidade desta técnica foi confirmada realizando-se um mínimo de três repetições para cada cepa. Os resultados obtidos produziram fragmentos de mobilidade aparentemente idênticos, indicando uma boa reprodutibilidade dos mesmos. Esta reprodutibilidade também foi encontrada no trabalho realizado por Ciapina, 1997.

No entanto, foi observado que os perfis genômicos obtidos pela técnica de PCR alteravam para a mesma cepa com a variação dos reagentes e suas concentrações nos PCRs, seguindo o protocolo de outras metodologias descritas na literatura. Ciapina (1997) também observou que o perfil dos DNAs obtidos pela técnica de PCR se alterava para a mesma linhagem quando variava-se o fornecedor da enzima Taq DNA polimerase. Contudo, a reação de PCR utilizada neste trabalho não apresentou estas diferenças com a variação de fornecedores da enzima Taq DNA polimerase (Figura 25a).

Os resultados obtidos mostraram que a seqüência BOX-A1R estavam presentes tanto no genoma de bactérias Gram-negativas quanto em bactérias Gram-positivas concordando com as conclusões de Versalovic et al., 1991; de Brujin, 1992; Louws, 1994 e Ciapina, 1997 de que esta seqüência é diferencialmente conservada e dispersa em diversos genomas bacterianos.

No entanto, a maioria desses trabalhos foram realizados com diferentes linhagens de somente 2 espécies de bactérias (exceto o trabalho de Pellizari et al., 1996), o que poderia justificar a eficácia do método para análises de caracterização de linhagens dentro de uma mesma espécie, mas não para a identificação e caracterização de diferentes espécies ambientais desconhecidas, apesar de no trabalho de Pellizari et al. (1996) terem sido obtidos agrupamento eficientes de bactérias Gram-positivas e Gram-negativas de origem ambiental.

Nesse estudo, só foi possível obter amplificação de 30 dos 61 isolados analisados. Segundo este resultado, pode-se sugerir que a seqüência do BOX-PCR, não está presente em todos os genomas bacterianos, ou que a distância entre as sequências do BOX-PCR é muito grande, impossibilitando a obtenção da amplificação do fragmento para este iniciador (Gilson Manfio, comunicação pessoal). Visto que todos esses isolados foram amplificados 
para o gene 16SrRNA e/ou genes catabólicos, não cabe a hipótese de que haveria algum interferente nas amostras de DNA extraídos que justificasse a não amplificação destes DNA pelo iniciador do BOX-PCR.

Considerando-se os 30 isolados amplificados pelo BOX-PCR, observou-se que os isolados $1.3 \mathrm{~T}$ e $1.5 \mathrm{~T}$ (isolados do mesmo ponto de coleta com hidrocarbonetos) e os isolados 3.2B e 3.4B, isolados do ponto 3, mas enriquecidos com bifenilo, foram considerados idênticos. Portanto, o número de isolados considerados a serem estudados pelas outras técnicas foram 59.

\subsection{Amplificação dos genes catabólicos através da técnica de PCR}

No presente trabalho, foram selecionados diferentes genes catabólicos para determinar e comparar a diversidade genotípica dos isolados presentes nas amostras do Estuário de Santos.

Os iniciadores estudados foram desenhados a partir de cepas específicas, o que conferEM especificidade para espécies de bactérias que possuam estas seqüências em seus genomas.

Apesar de muitos microrganismos isolados de ambientes contaminados e não contaminados, serem capazes de degradar hidrocarbonetos e organoclorados, pouco é conhecido sobres as características genéticas dos sistemas enzimáticos envolvidos na degradação destes compostos e sua prevalência no ambiente (Luz, 2001).

Considerando os compostos alifáticos somente sistemas alcano - hidroxilase de um pequeno número de bactérias Gram-negativas como de algumas Pseudomonas (van Beilen et al., 1994; van Beilen et al., 2001) e da Acinetobacter sp. ADP-1 (Ratajczak et al., 1998) têm sido geneticamente caracterizados em detalhes.

Além disso, recentemente foram encontrados e caracterizados múltiplos sistemas de alcano - hidroxilase em 2 linhagens de Rhodococcus (R. erythropolis NRRL B-16531 e Rhodococcus sp. Q15) isolados de localizações geográficas diferentes (Whyte et al., 2001b). Sendo estes microrganismos degradadores de alcanos que contém pelo menos 4 dos genes alcanos monoxigenases homólogos (Rh alkB1, Rh alkB2, Rh alkB3 e Rh alkB4) (Whyte et al., 2001b). 
De acordo com Whyte et al. (1996, 1998, 1999b) os genes de Rhodococcus sp. Q15 codificam monoxigenases que mineralizam alcanos de cadeia longa, como hexadecano $\left(\mathrm{C}_{16}\right)$ e octacosano $\left(\mathrm{C}_{28}\right)$ ou mesmo compostos com maior número de átomos de carbono. $\mathrm{O}$ fato do gene alk B1 ter sido descrito originalmente na cepa Rhodococcus sp. Q15 que degrada alcanos de cadeias longa $(\mathrm{C}>10)$, poderia indicar que os microrganismos isolados no presente trabalho possuem sistemas de oxidação preferencialmente para n-alcanos de cadeias curtas ou também que estes sistemas possam ser apenas não homólogos ao alkB1 e portanto não foram amplificados pelos iniciadores aqui empregados. Divergindo, desta forma com o trabalho de Luz (2001) que observou uma predominância de genes homólogos a alk B1 e a alk B2 nas amostras de solo coletadas em Cubatão e em Florianópolis.

Segundo Mesarch et al. (2000), bactérias que possuem vias de degradação aeróbia para degradar hidrocarbonetos aromáticos, sintetizam enzimas dioxigenases para ativar e clivar o anel benzênico. Desta forma, os genes correspondentes a cada uma dessas enzimas dioxigenases, são excelentes alvos para estudos de ambientes contaminados por petróleo e organoclorados, como é o caso do estuário de Santos.

No presente trabalho foi observada a presença de genes codificando para diferentes enzimas dioxigenases, demonstrando que estas enzimas estão presentes no estuário santista, e que um único microrganismo pode apresentar uma ou mais dioxigenases em seu genoma, como foi verificado em 8 dos isolados analisados (tabela 20 e 21).

$\mathrm{O}$ único gene codificando para a enzima dioxigenase que não apresentou amplificação neste trabalho, foi o gene $t f d \mathrm{C}$, apresentando amplificação apenas para a cepa controle (figura 27a). Esta ausência pode ter ocorrido devido a especificidade do primer para determinadas espécies de bactérias, como dito anteriormente, excluindo outras espécies de bactérias que poderiam estar degradando clorocatecóis nas amostras analisadas.

Segundo os resultados obtidos, foi possível notar que tanto o iniciador $t f d \mathrm{C}$ como o alk $\mathrm{B}$ não foram adequados para verificar a dispersão destes genes no estuário, sugerindo um sistema de oxidação de clorocatecois diferente do relacionado ao gene $t f d C$ na microbiota estudada.

Com relação aos iniciadores específicos para o gene naftaleno dioxigenase (nod B), foi possível observar fragmentos de $642 \mathrm{pb}$ (figura 27 a e b) para 3 dos 6 isolados enriquecidos com hidrocarbonetos obtidos a partir do Ponto 4 e em 1 dos 5 isolados em 
óleo diesel no ponto 3. Ambos os pontos apresentaram altas concentrações de hidrocarbonetos aromáticos policíclicos nas amostras de sedimento analisadas. Também pôde-se observar que o ponto 4 , localizado em frente a COSIPA, é o ponto que apresentou a maior concentração de naftaleno dentre os nove pontos analisados (tabela 14). O segundo ponto a possuir a maior concentração de naftaleno entre as amostras analisadas é a região do Rio Santo Amaro (ponto 6), contudo este ponto não apresentou nenhum microrganismo isolado com o gene de degradação para naftaleno. No caso do ponto 3, não foi detectado a presença de naftaleno, entretanto apresentou um microrganismo com o gene codificando para a naftaleno dioxigenase.

Este gene $(\operatorname{nod} \mathrm{B})$ também não foi encontrado em nenhum dos isolados enriquecidos com bifenilo. O que condiz com o trabalho de Pellizari et al. (1996) que também não encontrou, em suas amostras de Cubatão, isolados em bifenilo que apresentassem a enzima relacionada ao naftaleno-dioxigenase (nah), enzima altamente similar a codificada pelo ndoB. Além disso, no trabalho realizado por Tiedje et al. (1994), 3 autores sugeriram que que a dispersão do operon nah na região tropical ainda não estaria completa.

O gene catabólico $x y l \mathrm{E}$ (figura 27b) que codifica para a enzima 2,3-catecoldioxigenase foi encontrado tanto em isolados enriquecidos em bifenilo como em isolados enriquecidos em hidrocarbonetos. Este fato é justificado por enzimas 2,3-catecol dioxigenases estarem presentes entre o grupo de compostos aromáticos como benzeno, tolueno, xilenos, fenol, naftaleno e bifenilo que apresentam pelo menos uma via de degradação envolvendo estas enzimas (Mesarch et al., 2000). Contudo, entre os genes estudados, o gene $x y l$ E foi o que apresentou o menor número de positividade, apesar de estar relativamente disperso no Estuário de Santos, pois foi encontrado nos pontos de coleta 1, 3, 6 e 8 ao contrário do gene nod B que só foi encontrado nos pontos de coleta 3 e 4 .

A presença de um pequeno número de isolados que apresentaram o gene $x y l \mathrm{E}$ poderia ser explicado também pelo fato de haver diversos genes envolvidos na síntese destas enzimas degradadoras. Este gene está principalmente envolvido na degradação de compostos aromáticos como o tolueno e o xileno.

Segundo Wikström et al. (1996), as vias de meta-clivagem da enzima 2,3-catecol dioxigenase é formada por superfamílias de enzimas, o que a torna um alvo em potencial para o monitoramento de populações bacterianas capazes de clivar os anéis aromáticos e 
também para monitar os passos finais na degradação de alguns PAHs (hidrocarbonetos aromáticos policíclicos).

Em nosso estudo, talvez outros genes pertencentes à estas superfamílias da enzima 2,3-catecol dioxigenase possam estar presentes nos isolados que não apresentaram amplificação para este iniciador $(x y l \mathrm{E})$, visto a quantidade de genes distintos responsáveis pela síntese da enzima 2,3-catecol dioxigenase.

A pesquisa do gene $b p h \mathrm{~A}$ mostrou que, este não foi encontrado em nenhuma das amostras isoladas com hidrocarbonetos, contudo, esteve presente em 6 dos 15 isolados enriquecidos com bifenilo (tabela 16).

Dentre os pontos que foram obtidos isolados, os pontos 1 e 8 , apresentaram o gene bphA apesar da baixa concentração de PCBs nos sedimentos (respectivamente 1,3 e 1,39 ng. $\mathrm{g}^{-1}$ ). Por outro lado, o ponto mais poluído (ponto 4) não apresentou o gene $b p h \mathrm{~A}$, o que não significa que estes isolados não possam degradar PCBs. Pois, segundo Bertacini (1998), em seu trabalho não foi encontrado nenhuma homologia entre seus consórcios degradadores de PCBs e a sonda que codifica para os genes bphABC. Além disso, Mondello (1989) e Pellizari et al. (1996), relataram que a presença de genes que codificam para as enzimas envolvidas na degradação de PCBs podem não estar relacionados com o potencial de degradação de bactérias em solos contaminados por PCBs.

Apesar da ausência deste gene estudado nos isolados, em alguns pontos pouco ou muito contaminados, não significa que estes isolados não tenham os genes de degradação para PCBs, isto porque existem vários genes envolvidos na degradação de PCBs. Como foi observado no trabalho de Asturias \& Timmis (1993) que trabalhando com os genes bph de Rhodococcus globerulus P6, não verificaram a existência de homologia com a seqüência de genes bphABC de P. pseudoalcaligenes KF 707.

Contudo, segundo Furukawa et al. (1989) os genes bph possuem uma particularidade, alguns genes $b h p$ de diversas cepas são extremamente homólogos entre si, o que poderia indicar que haveria um ancestral comum relacionado ao gene $b p h$ entre as cepas que possuem este gene.

Tendo em vista que alguns genes $b p h$ são homólogos e outros são totalmente diferentes, faz com que se possa agrupar as cepas degradadoras de PCBs em 4 grupos: sendo que o primeiro grupo de operons $b p h$ são muito parecidos se não iguais ao da $P$. 
pseudoalcaligenes KF707; o segundo grupo é homologo com os genes da P. putida KF715, mas com um perfil no mapa de restrições diferente; o terceiro grupo apresenta uma baixa homologia com a KF 715; e o quarto grupo não apresenta homologia com o operon da KF 707 (Taira et al., 1992). No presente trabalho, foi apenas estudado o primeiro grupo de classificação do gene $b p h$, devido o trabalho ter sido realizado com o gene oriundo da cepa P. pseudoalcaligenes KF 707 (Taira et al., 1992).

A partir dos resultados foi possível observar que quase $50 \%$ dos isolados obtidos a partir do bifenilo apresentaram o gene $b p h$. Podendo-se concluir que existe uma predominância de gene bph do grupo da $P$. pseudoalcaligenes KF 707 nos pontos estudados.

Com relação ao gene tod C1 (figura 27 a,b), pôde-se observar pelas tabelas 20 e 21 que foi o mais encontrado nos isolados do estuário. Este gene também foi o mais freqüentemente detectado nas amostras de solo do Brasil estudadas por Luz (2001).

O gene tod $\mathrm{C} 1$ codifica para a subunidade maior da dioxigenase terminal, sendo um dos três componentes da enzima tolueno dioxigenase, envolvida na via de degradação do tolueno (Furukawa, 1987). Também foi possível observar que este gene se encontra nos pontos de coleta que apresentaram as maiores concentrações de hidrocarbonetos aromáticos policíclicos (PAHs) (pontos 2, 3, 4).

$\mathrm{O}$ fato da existência destes genes de forma dispersa se deve a existência destes genes catabólicos em transposons e plasmídeos, proporcionando sua mobilidade e acelerando o potencial evolucionário destes genes (Taira et al, 1992; van der Meer et al., 1992; Gibson et al., 1993 e Kamamaru et al., 1998). Além disso, no trabalho de Furukawa (1994) foi mostrado grandes similaridades na organização genética e nas seqüências de nucleotídeos de genes individuais entre o metabolismo de bifenilo expressado pelo operon bph e o metabolismo do tolueno expressado pelo operon tod. Segundo Furukawa (1994), para a subunidade maior da dioxigenase terminal do gene tod $\mathrm{C} 1$ e do gene $b p h \mathrm{~A} 1$ há $68 \%$ de homologia nas seqüências de nucleotídeos e 65\% de homologia na seqüências dos amino ácidos entre estes genes. Justificando desta forma a presença dos genes tod $\mathrm{C} 1$ nos isolados crescidos em bifenilo e a presença deste gene no Estuário de Santos.

Além disso, foi possível observar que no ponto 4 houve predominância do genótipo $n d o \mathrm{~B}$, tod $\mathrm{C} 1$ entre os isolados obtidos com hidrocarbonetos, enquanto estes genes não 
foram detectados empregando o bifenilo. Já no ponto 1, todos os isolados crescidos em bifenilo foram positivos para o gene tod $\mathrm{C}$, no entanto, este gene não foi detectado nos isolados obtidos a partir dos hidrocarbonetos. Portanto, os diferentes substratos empregados não selecionaram populações com os mesmos genótipos a partir da mesma amostra de sedimento. Com isto podemos sugerir que cada substrato possa ter atuado durante o enriquecimento, favorecendo a seleção de microrganismos com genótipos específicos ou mesmo que possa ter ocorrido, durante o processo de enriquecimento, transferência horizontal de genes. A hipótese de transferência horizontal de genes é provável, uma vez que apenas nos pontos 1 e 4 foram detectados a presença destes genótipos e também pelo fato de se ter diversos relatos na literatura de transferências de genes catabólicos via

plasmídios ou mesmo transposons. No entanto o enriquecimento foi realizado sob agitação o que poderia dificultar o contato celular.

Portanto, os genes tod $\mathrm{C} 1$ e bph A foram os que predominaram nas amostras do estuário, e o gene $x y l \mathrm{E}$ foi o mais disperso no mesmo, sendo encontrado em diferentes pontos de amostragem, enquanto que o gene alk $\mathrm{B}$ e tfdC não foram encontrados em nenhum dos isolados. Os isolados dos pontos 1 e 4 foram os que apresentaram mais genes catabólicos. Esses dados, demonstram a presença de diferentes dioxigenases no estuário e que há uma grande diversidade genética de bactérias degradadoras que contribuem para a adaptação destas populações bacterianas frente a um habitat extremamente impactado como o do estuário santista.

\subsection{Teste de biodegradação dos congêneres de PCBs}

A análise da capacidade de degradação foi realizado em 13 isolados crescidos em bifenilo. Os resultados obtidos estão apresentados na tabela 22 .

A partir dos dados obtidos podemos notar que o congênere que apresentou melhor degradação, igual a 100\%, foi o PCB 3. O fato de um congênere monoclorobifenilo, 4-CB (PCB3) apresentar melhor degradação em relação aos demais é justificável pela presença de apenas um cloro na molécula de bifenilo, sendo desta forma uma molécula facilmente degradável pelos microrganismos aeróbios (Furukawa, 1987). 
A partir dos dados obtidos no sedimento do estuário, pode-se notar que os PCBs mais leves (PCB-8 a PCB-39) estavam presentes em menores concentrações. Segundo Bonetti (2000), congêneres mais leves tem maior solubilidade em água do mar, sendo mais facilmente degradados do que os congêneres mais pesados (PCB- 52, PCB 97, PCB101, PCB 153) que geralmente se encontram associados à matéria orgânica, devido a sua maior lipofilicidade. Portanto, os congêneres mais leves são mais biodisponíveis que os pesados, permitindo uma melhor adaptação dos microrganismos a estes poluentes e portanto, melhor degradação destes.

Segundo Furukawa (1987), PCBs que possuem todos os cloros em um único anel é geralmente degradado mais rapidamente que os congêneres que possuem o mesmo número de cloro nos dois anéis aromáticos da molécula de bifenilo. Este fato poderia justificar a menor degradação dos demais congêneres de PCBs analisados, visto que todos, exceto o PCB3, possuem ao menos 1 cloro em cada um dos anéis benzênicos.

Outro congênere importante de salientar é o PCB 153 que apresentou uma degradação um pouco abaixo de 50\%, variando de $33,6 \%$ a $46 \%$ em algumas amostras. No entanto, este congênere é de grande interesse de estudo pois é um composto indutor do tipo fenobarbital freqüentemente relatado em amostras ambientais e que possui alta toxicidade, e também é um composto de difícil degradação para os microrganismos aeróbios por ser um composto altamente clorado (hexaclorobifenilo). Existem poucos relatos de degradadores aeróbios de congêneres pesados de PCBs. Este congênere apresentou maior porcentagem de degradação nos isolados 3.2B (43,4\%), 1.1B, 1.2B, 1.7B e 4.2B (45,8\%, $44 \%, 35,4 \%$ e $33,6 \%$ respectivamente).

A partir dos dados obtidos é possível notar que os pontos que apresentaram melhor degradação dos congêneres de PCBs foram os pontos 3 e 4 . O ponto 3 foi o local que apresentou a maior concentração de PCBs, depois do ponto 4. Ambos sofrem a influência da COSIPA, Coperbrás, Solo Rico, Manah, Cia Brasileira de Estireno e Ultra fértil entre outras empresas e também de esgotos sendo locais altamente impactados.

A partir dos dados obtidos através das análises cromatográficas dos sedimentos, verificou-se que o Ponto 1 obteve uma das mais baixas concentrações de PCBs e o bifenilo nem foi detectado, no entanto foi verificada degradação de PCBs por alguns isolados. Esta capacidade de degradação em um área de baixa concentração de PCBs e nenhuma presença 
de bifenilo pode ser explicada pela presença de vegetação nos arredores dos locais da coleta. Isto porque, segundo Kumamaru et al. (1998), bactérias envolvidas no estágio final de degradação de ligninas de plantas também são capazes de degradar bifenilo, sendo dessa forma encontradas em diversas amostras ambientais.

É importante observar também, que a cepas 1.4B, 1.5B e 1.7B apesar de possuirem o gene $b p h \mathrm{~A}$, apresentaram baixa ou nenhuma degradação de PCBs. Por exemplo, o ponto $1.5 \mathrm{~B}$ não degradou nem mesmo os congêneres mais leves. O que pode ser justificado pela possível ausência de expressão do gene ou pelo fato da alta seletividade enzimática do congênere (Brown et al., 1987 e Williams, 1997), sugerindo que a enzimas destes isolados não sejam específicas para a degradação dos presentes congêneres estudados ou mesmo que o fato de se detectar a presença do gene não necessariamente indica a expressão do gene ou que ele possa ser ativado para degradar outros compostos.

Além disso, segundo Bedard \& Quensen (1995), a remoção do cloro (processo de desclorinização), não é determinada estritamente pela posição relativa do cloro no anel oposto do bifenilo (se é posição meta, para ou orto), mas também pela configuração dos cloros na molécula.

Diversos fatores podem justificar as diferentes atividades de degradação. Estudos relataram que a temperatura (Wu, 1997) e a adição de certos compostos, como por exemplo Triton -100 X e surfactantes, podem alterar de forma significativa a degradação e a taxa de desclorinização de PCBs (Fava, 1996).

Em relação aos 3.2B e $8.5 \mathrm{~B}$, além de ter sido encontrado o gene bphA, esses também apresentaram alta taxa de degradação para alguns congêneres. O que significa que este ou outros genes estão sendo induzidos e que estas cepas possuem enzimas capazes de degradar alguns destes congêneres de PCBs estudados.

No caso do ponto 4, que apresentou isolados capazes de degradar diversos congêneres, desde congêneres leves até os mais pesados, não foi obtido nenhuma amplificação para o gene $b p h \mathrm{~A}$, confirmando que estes isolados devem possuir outra seqüência de genes envolvidos na degradação destes compostos, corroborando as afirmações dos trabalhos de Bertacini (1998) e Asturias \& Timmis (1993). 


\subsection{Teste de biodegradação dos hidrocarbonetos do petróleo}

A análise da capacidade de degradação foi realizada para 47 isolados. Os resultados obtidos estão representados na tabela 23.

Segundo os resultados dos genes catabólicos, os isolados de hidrocarbonetos dos pontos 1, 4, 5 e 9 não apresentaram resultados positivos para nenhum dos genes catabólicos estudados. Contudo, praticamente todos os isolados destes pontos apresentaram capacidade de degradar um ou mais hidrocarbonetos. Principalmente os do ponto 4, que apresentaram as melhores atividades de degradação para diversos compostos.

Tendo em vista a ocorrência de degradação de hidrocarbonetos em diversos pontos de coleta e o fato destes isolados apresentarem um baixo número de seqüências homólogas aos genes catabólicos selecionados, além de haver na literatura, uma grande diversidade de genes que codificam para enzimas específicas para diversos hidrocarbonetos, pode-se concluir que na área estudada devemos ter a ocorrência de outros genes envolvidos na atividade de biodegradação.

Portanto, a microbiota presente nos sedimentos do estuário podem apresentar sistemas genéticos envolvidos na degradação de alcanos e PAHs, distintos daqueles detectados pelos genes catabólicos estudados, que lhes conferiria também uma especificidade distinta. Uma vez que a diversidade de dioxigenases parece ser bastante alta, é muito provável que devem haver outros genes não descritos ainda na literatura que contribuam para a metabolização de poluentes.

De acordo com Fulthorpe et al. (1998), a alta diversidade genotípica dentro de uma população, sugere que a habilidade de catabolizar determinados compostos é relativamente antiga, ou que a transferência horizontal de novos genes entre cepas relacionadas é uma característica comum. Lorenz \& Wackernagel (1994) e Herrick et al. (1997) afirmaram que a transferência horizontal de genes catabólicos, pode ser um fator chave na evolução de populações bacterianas e na adaptação de comunidades microbianas em ambientes contaminados.

Whyte et al. (1997) \& Laramée et al. (2000), sugerem que trocas genéticas de vias degradativas podem ocorrer na natureza, devido ao fato de muitas enzimas catabólicas estarem localizadas em plasmídios ou elementos genéticos móveis, como transposons. A 
presença de plasmídios e transposons justificaria a capacidade de diversos microrganismos degradarem diferentes poluentes, como hidrocarbonetos aromáticos, alifáticos e até mesmo PCBs, como foi observado nos isolados de bifenilo do ponto 1.

Estes isolados, além de degradarem PCBs, também apresentaram capacidade de degradar diversos hidrocarbonetos. Segundo Gilbert et al. (1997) e Kosono et al. (1997) e como já descrito anteriormente, diversos estudos têm demonstrado que certos compostos aromáticos naturais presentes em plantas, tais como lignina e terpenos, podem ser utilizados como substratos naturais para a indução de genes catabólicos, o que poderia justificar a presença de bactérias que degradam outros compostos aromáticos (como os PAHs), assim como os PCBs no estuário de Santos.

No casos dos isolados, $2.3 \mathrm{~T}$ (ponto 2), 6.3T e 6.4T (ponto 6), além destes não terem apresentado capacidade de degradação de nenhum dos compostos estudados, também não foi observado nenhum gene catabólico, exceto no 6.3T que apresentou o gene $x y l \mathrm{E}$. $\mathrm{O}$ fato deste isolado ter o gene catabólico para a via de degradação do xileno e não o ter degradado, poderia ser justificada pela não ativação do gene ou pela falta dos genes reguladores $(x y l \mathrm{~S}$ e $x y l \mathrm{R})$ que controlam positivamente os dois promotores do gene $x y l$ ou mesmo pela não ativação ou falta do operon $x y l \mathrm{CAB}$ que inicializa a via de degradação do xileno.

No ponto 3, além de ter sido observada a presença do gene ndo B (que codifica para a naftaleno dioxigenase), foi possível observar que também o naftaleno foi o composto mais degradado pelos isolados deste ponto, sugerindo uma possível atividade deste gene. $\mathrm{O}$ mesmo ocorreu no ponto 8 , que também apresentou isolados com excelente taxa de degradação para o xileno além de apresentar o gene $x y l \mathrm{E}$.

Em relação ao nonano, que é um n-alcano linear, considerado um dos hidrocarbonetos mais facilmente degradáveis (Linch \& Hobbie, 1988), foi de fato o composto mais degradado pelos isolados do estuário. Contudo como dito anteriormente, não foi observada a presença da alcano - monoxigenase codificada pelo gene alkB.

Tendo em vista que este gene alkB1, pertencente a cepa Rhodococcus Q15, tende a degradar alcanos de cadeias longas $(\mathrm{C}>10)$ e o nonano é um alcano de cadeia curta $\left(\mathrm{C}_{9}\right)$, sugeriria que os microrganismos isolados no presente trabalho possuem um sistema de oxidação para n-alcanos de cadeias curtas. Entretanto, estes dados não descartam a 
possibilidade destes microrganismos também degradem compostos de cadeias longas, pois estes compostos não foram testados no presente trabalho

Portanto, é possível inferir que as populações microbianas no estuário apresentam uma grande biodiversidade. Porém, existe pouca informação à respeito das diferenças fenotípicas e genotípicas que podem existir entre os microrganismos isolados. Dessa forma, entende-se que é muito importante seguir estudando a biodiversidade genotípica e fenotípica e os processos ecológicos responsáveis pela manutenção desta diversidade no estuário de Santos.

Tendo em vista que a biorremediação tem sido proposta como solução para atenuar os problemas de contaminação em ambientes poluídos, através da utilização de microrganismos autóctones, torna-se cada vez mais necessário, conhecer e entender a diversidade das comunidades microbianas e os parâmetros que poderiam estar envolvidos neste processo, como foi desenvolvido no presente estudo.

A partir dos resultados de biodegradação e dos demais resultados foi possível notar que esta área tem um forte potencial para biorremediação com microrganismos autóctones, considerando a capacidade dos isolados em degradar hidrocarbonetos e mesmo PCBs. Além disso, os diversos parâmetros ambientais (parâmetros físico-químicos, análises dos sedimentos, contagem de heterotróficas) indicaram que está área apresenta processo de biodegradação "in situ" tanto de hidrocarbonetos como de PCBs. Como exemplo deste processo é possível citar o ponto 4 (que recebe influência direta do lançamento da Cosipa), que foi considerado o ponto mais impactado entre todos os outros pontos, e apresentou as maiores concentrações de poluentes aromáticos, organoclorados e alifáticos. Este ponto apresentou as maiores contagens de heterotróficas e o mais baixo valor de potencial redox no sedimento, mostrando a presença de atividade biológica no local. Além disso, foi verificada, pelos resultados de biodegradação de hidrocarbonetos e PCBs, a presença de potentes degradadores com atividade frente a quase todos os compostos aqui estudados. Corroborando estes dados, foi verificado um valor elevado de UCM (mistura complexa não resolvida) e um valor superior a 2 na razão do pristano/C17, indicando que realmente, está ocorrendo um processo de biodegradação neste local. Isto demonstra, a possibilidade de recuperação desta área, que é a mais afetada do estuário, empregando-se tecnologias de 
biorremediação em conjunto com o tratamento dos efluentes industriais lançados continuamente no estuário.

\subsection{Caracterização taxonômica dos isolados}

A caracterização taxonômica dos isolados obtidos através da análise do seqüenciamento, mostrou que o maior número dos isolados se encontram dentro do grupo filogenético de Proteobactéria na subdivisão Gama Proteobactéria, no qual 38 dos 50 isolados foram similares a Klebsiella sp., Serratia sp., Pseudomonas sp., Acinetobacter sp. e gama proteobactéria não cultivável. Estas bactérias são todas Gram negativas condizente com os resultados da coloração de Gram obtidos.

A subdivisão Gama Proteobactéria foi a mais encontrada entre os microrganismos isolados. Esta possui diversos microrganismos já descritos na literatura que são capazes de degradar hidrocarbonetos e PCBs, como espécies do gênero Pseudomonas sp. e Acinetobacter sp. Contudo, não há descrição na literatura de cepas como Klebsiella sp. e Serratia sp. com capacidade de degradar PCBs e hidrocarbonetos, apesar de várias espécies de Klebsiella pneumoniae já terem sido descritas como sendo degradadoras de DDT (1,1,1 -Tricloro-2,2-bis- 4'- clorofenil etano), acetileno, benzonitrilo e bromoxinil (http://umbbd.ahc.umn.edu/search/micro.html).

No presente estudo, diversos isolados deste gênero encontrados no estuário apresentaram boa capacidade de degradação destes compostos. Neste trabalho também foi possível observar, que as cepas de Pseudomonas encontradas no ponto 1, enriquecidas com bifenilo, apresentaram boa capacidade de degradação tanto de hidrocarbonetos como de PCBs, corroborando os dados da literatura. No entanto, no caso das cepas de Acinetobacter sp. encontradas, apenas a cepa 7.2T, apresentou boa capacidade de degradação, as demais apresentaram baixa ou nenhuma capacidade de degradar os compostos estudados, como foi o caso das cepas $6.4 \mathrm{~T}$ e $7.3 \mathrm{~T}$.

Outras bactérias encontradas no estuário que pertencem à divisão Proteobactéria, mas não pertencem a subdivisão Gama são os gêneros Comamonas sp., Pandoraea sp. e Agrobacterium sp., sendo que os dois primeiros gêneros pertencem à Beta subdivisão e o último pertence à Alfa subdivisão. Tanto o gênero Comamonas sp. como Agrobacterium 
sp. possuem espécies que foram descritas na literatura como sendo capazes de degradar diversos compostos xenobióticos. Além disso, no caso da Comamonas sp. há relatos de espécies que degradam hidrocarbonetos aromáticos.

No presente trabalho também foi encontrado um isolado do gênero Staphylococcus sp., este gênero também já foi descrito como sendo capaz de degradar diversos compostos xenobióticos como dibenzofurano, fluoreno, trinitrotolueno e arsonoacetato. Este gênero apesar de não ter sido classificado como sendo degradador de hidrocarbonetos do petróleo, no presente trabalho, este gênero apresentou alta capacidade de degradar diversos compostos do petróleo. Sugerindo que este gênero também seja capaz de degradar outros compostos xenobióticos como hidrocarbonetos do petróleo, apesar deste fato ainda não ter sido descrito na literatura.

Um outro gênero bastante descrito na literatura como capaz de degradar diversos compostos xenobióticos inclusive hidrocarbonetos e PCBs é o Rhodoccocus sp. Este gênero foi encontrado nos isolados do ponto 8 enriquecidos com bifenilo. Este gênero têm sido bastante descrito na literatura por demonstrar a importância de bactérias Gram positivas na biodegradação e principalmente pela grande versatilidade do gênero no catabolismo de diversos hidrocarbonetos aromáticos. Asturias \& Timmis (1993) relataram a presença de múltiplas dioxigenases em uma cepa de Rhodococcus globerulus P6 na degradação de PCBs.

Malachowsky et al. (1994) descreveram o potencial de cepas de Rhodococcus rhodochrous isoladas do ambiente em mineralizar tricloroetileno, cloreto de vinila e vários compostos aromáticos, como tolueno, naftaleno e bifenilo. Masai et al. (1995) isolaram a cepa Rhodococcus sp. RHA1 que degrada de mono- a pentaclorobifenilo.

As cepas de Rhodococcus sp. encontradas no presente estudo, além de apresentarem o gene $b p h \mathrm{~A}$, também apresentaram boa taxa de degradação de congêneres leves de PCBs.

Em relação aos resultados obtidos no BOX-PCR e no seqüenciamento, observamos que o agrupamento das cepas pelo método de BOX-PCR não foi eficaz. Visto que várias cepas que foram consideradas distintas no BOX-PCR, eram cepas da mesma espécie, segundo os dados obtidos no seqüenciamento. Além disso, em alguns casos, cepas de espécies diferentes foram agrupadas apresentando uma distância filogenética pequena em relação a cepas da mesma espécie. Isto foi possível observar nas cepas do ponto 1 
enriquecidas com bifenilo e nas cepas do ponto 2 e 3 enriquecidas com hidrocarbonetos. Estes resultados discordam do trabalho de De Bruijn (1992) e Ka et al. (1995), mas concordam com o trabalho de Pellizari (1995) que quando trabalhou com cepas ambientais, não obteve correlação entre os dados da técnica de REP-PCR e a identificação por FAME.

No trabalho de De Bruijn (1992) a técnica de REP-PCR foi utilizada como um eficiente método em estudos de seleção de microrganismos para eliminar cepas similares, além de empregá-lo para a identificação de patógenos de plantas, entre outros. Ka et al. (1994) também utilizaram com sucesso a técnica de REP-PCR para a identificação de 47 isolados de bactérias degradadoras de 2,4-D e o agrupamento dos diferentes padrões de bandas corresponderam com a identificação obtida por FAME.

Além da identificação ter apresentado um resultado diferente da técnica de BOXPCR, as identificações obtidas não apresentaram correlação com o estudo dos genes catabólicos e/ou a habilidade de degradar PCBs ou hidrocarbonetos. Visto que cepas da mesma espécie, apresentaram diferente capacidade de degradação frente aos diversos hidrocarbonetos estudados, como foi obtido nos isolados identificados como Acinetobacter sp.(7.2T, 7.3T) e Serratia marcescens (1.2T, 5.4T). Além disso, no caso das cepas identificadas como Klebsiella pneumoniae (1.1T, 1.4T, 4.1T, 6.2T), foi observado que tanto a capacidade de degradação para diferentes hidrocarbonetos era distinta, como também haviam em algumas cepas a presença de genes catabólicos enquanto que em outras estes genes estavam ausentes.

Também foi possível observar a presença de genes catabólicos idênticos em espécies diferentes de bactérias obtidas no mesmo ponto de coleta, como pode ser observado nos isolados do ponto 1 enriquecidos com bifenilo, em que o isolado 1.4B (Gama proteobactéria não cultivável) e as demais cepas (Pseudomonas sp.) apresentaram o gene tod $\mathrm{C} 1$. O mesmo foi observado nos isolados do ponto 4 enriquecidos com hidrocarbonetos, que apresentaram tanto o gene ndoB e tod $\mathrm{C} 1$ nas cepas Klebsiella pneumonie (4.1T), Pandoraea sp. (4.3T e 4.6T) e Calymmatobacterium granulomatis (4.4T). Este resultado poderia sugerir que possa estar ocorrendo transferência horizontal de genes catabólicos no estuário. Esta hipótese é corroborada pelos dados da literatura discutidos anteriormente e pelos dados de granulometria obtidos no presente trabalho que mostraram que as amostras coletadas se encontram em locais de baixa hidrodinâmica, o que 
poderia estar facilitando a transferência de genes entre microrganismos, justificando desta forma, a presença de genes idênticos em espécies distintas de bactérias.

A partir dos dados obtidos, foi possível também observar um maior número de gêneros distintos no enriquecimento com bifenilo do que com hidrocarbonetos, tendo em vista que dos 15 resultados de identificação dos isolados enriquecidos com bifenilo, foram obtidos 7 gêneros distintos. No caso dos isolados com hidrocarbonetos, dos 36 isolados identificados foram obtidos 8 gêneros distintos. Estes dados indicam a possibilidade de uma diversidade de microrganismos degradares de diferentes compostos no estuário santista. 


\section{CONCLUSÕES}

- Os parâmetros físico-químicos mostraram que o sedimento do estuário possui potencial redox negativo, indicando grande decomposição de matéria orgânica e/ou um sedimento com baixa aeração, favorecendo procesos anaeróbios.

- A granulometria do sedimento mostrou que a hidrodinâmica do estuário é baixa, propiciando a sedimentação e retenção de poluentes junto à matéria orgânica.

- As análises de hidrocarbonetos nos sedimentos demonstraram que estes compostos são principalmente de origem antropogênicas. Contudo foi demonstrado que nos pontos 3 , 5, 6, 7, 8, 9 ocorre também o aporte de hidrocarbonetos de origem biogênicas.

- As análises de hidrocarbonetos no sedimento também demonstraram que há ocorrência de degradação de hidrocarbonetos nos pontos 2, 3, 4 e 6 do estuário.

- As análises de PCBs no sedimento mostraram que apesar das concentrações de PCBs no estuário estarem abaixo do nível em que se caracteriza uma área de alto grau de poluição, existem indicativos de presença de compostos de misturas comerciais no local.

- A contagem de bactérias heterotróficas confirmou a atividade biológica na área estudada. Demonstrou também a capacidade de adaptação de microrganismos nas áreas mais impactadas, como no ponto 4 .

- Foram obtidos 45 isolados a partir de todos os consórcios crescidos em hidrocarbonetos. Contudo, foram obtidos somente 16 isolados, que utilizavam o bifenilo como substrato, a partir dos pontos 1, 2, 3 e 8 .

- No ponto 5 foi obtido um consórcio que crescia em bifenilo, contudo não foram obtidos isolados, sugerindo um sinergismo na comunidade microbiana.

- A técnica do BOXA1R-PCR apresentou boa reprodutibilidade e demonstrou a presença de 28 padrões de bandas distintos a partir dos 61 isolados.

- Os genes $t f d \mathrm{C}$ e alk B1 não foram detectados em nenhum dos isolados.

- Não foram encontrados genótipos específicos associados a atividade de degradação dos poluentes estudados.

- Entre os genes catabólicos que codificam para as enzimas dioxigenases, o $\operatorname{tod} \mathrm{C} 1$ e o bph A foram os genes mais freqüentemente encontrados nos isolados. 
- As amostras dos pontos 3 e 4 foram as que apresentaram as melhores taxas de degradação de PCBs, além de serem os pontos mais impactados.

- O ponto 4 foi o que apresentou a melhor capacidade de degradação para os hidrocarbonetos estudados.

- O presente trabalho mostrou que a maioria dos isolados se encontram dentro do grupo filogenético de Proteobactéria na subdivisão Gama Proteobactéria e que o gênero mais encontrado no estuário foi Klebsiella sp.

- Foram encontrados no estuário 11 gêneros distintos de bactérias, sendo os gêneros Acinetobacter sp., Pseudomonas sp., Comamonas sp. e Rhodococcus sp. os mais freqüentemente descritos na literatura como sendo degradadores de hidrocarbonetos de petróleo e/ou PCBs.

- Não foram observadas correlações entre a presença de genes catabólicos e/ou habilidade de degradar entre cepas da mesma espécie.

- Os dados do BOX-PCR e as análises dos seqüenciamentos foram divergentes. O BOXPCR não foi eficiente no agrupamento de cepas da mesma espécie.

- A partir dos resultados de biodegradação e dos resultados de caracterização do estuário foi possível notar que esta área tem um forte potencial para biorremediação com microrganismos autóctones. Além disso, os diversos parâmetros ambientais (parâmetros físico-químicos, análises dos sedimentos, contagem de heterotróficas) indicaram a ocorrência de biodegradação "in situ". 


\section{REFERÊNCIAS BIBLIOGRÁFICAS}

ABRAMOWICZ, D. A. Aerobic and anaerobic biodegradation of PCBs. Biotechnology, v.10, p. 241-250, 1990.

AHMED, M.; FOCHT,D.D. Degradation of polychlorinated biphenyls by two species of Achromobacter. Can. J. Microbiol., v.19, p.47-52, 1973.

ALEF, K.; NANNIPIERI, P. Methods in Applied Soil Microbiology and Biochemistry. San Diego: Academic Press, 1995.

ALEXANDER, M. Biodegradation and bioremediation. San Diego: Academic Press, 1994.

ALMEIDA, F.F.M. \& CARNEIRO, C. dal R.. Origem e evolução da Serra do Mar. Rev. Bras. Geociênc., v.28, p.135-150, 1998.

ALVES, G. Vazamento de óleo tóxico atinge favela do Rio. O Estado de São Paulo, São Paulo: 3 de julho de 1996. Cidades, v. 117, n.37.513.

AMANN, R.I.; LUDWIG, W.; SCHLEIER, K.H.. Phylogenetic identification and in situ detection of individual microbial cells without cultivation. Microbiol. Rev., v.59, p. 143-169, 1995.

AMERICAN PUBLIC HEALTH ASSOCIATION- APHA. Standard Methods for the examination of water and wastewater. $19^{\mathrm{a}}$ Edição, Washington: APHA, AWWA, WEF, 1995.175p.

ARAÚJO FILHO, J. R. Santos, o porto do café. Biblioteca Geográfica Brasileira. Série A. Publicação 24. Rio de Janeiro: IBGE, 1969. 200p.

ARENSDOF, J.J.; FOCHT, D.D. Formation of chlorocatecol meta cleavage products by a pseudomand during metabolism of monochlorobiphenyls. Appl. Env. Microbiol., v.60, p.2884-2889, 1994.

\section{De acordo com:}

ASSOCIAÇÃO BRASILEIRA DE NORMAS TÉCNICAS.

NBR 6023: Informação e Documentação - Referências - Elaboração. Rio de Janeiro: ABNT, 2000. 22p.

NACIONAL LIBRARY OF MEDICINE. List of journals indexed in Index Medicus. 2001. Avaiable from:

www.ncbi.nlm.nih.gov/entrez/jrbrowser.cgi

www.nlm.nih.gov/tsd/serials/lji.html 
ARNETT, C.M.; PARALES, J.V.; HADDOCK, J.D. Influence of chlorine substituents on rates of oxidation of chlorinated biphenyls by the biphenyl dioxigenase of Burkholderia sp. strain LB400. Appl. Environ. Microbiol., v.66, p. 2928-2933, 2000.

ASSAF-ANID, N.; NIES, L.; VOGEL, T.M. Reductive dechlorination of a polychlorinated biphenyl congener and hexachlorobenzene by vitamin $\mathrm{B}_{12}$. Appl. Environ.

Microbiol., v.58, v.1057-1060, 1992.

ASTURIAS, J.A; TIMMIS K.N. Three 2,3-dihydroxybiphenyl-1,2-dioxigenase genes in the Gram-positive polychlorobiphenyl-degrading bacterium Rhodoccocus globerulus P6. J. Bacteriol., v.175, p.4631-4640, 1993.

ATKINS, P.W.; JONES, L.L. Princípios de Química: questionando a vida moderna e o meio ambiente. Porto Alegre: Artmed, 2001. 914p.

ATLAS, R. M.; SEXSTONE, A.; GUSTIN, P.; MILLER, O.; LINKINS, P.; EVERETT, K. Biodegradation of crude oil by tundra soil microorganisms, p21-28. In: OXLEY, T.A.; BECKER, G., ALLSOP, D. (Ed.). Prodeedings of the $4^{\text {th }}$ International Biodegradation Symposium. London: Pitman, 1980.

ATLAS, R.M.. Microbial degradation of petroleum hydrocarbons: an environmental perspective. Microbiol. Rev., v.45, p.180-209, 1981.

ATLAS, R.M.; BARTHA, R. Microrganisms and some novel Pollution Problems. In: Microbiol Ecology. 2. ed. Mento Park: The Benjamin/Cummings, 1987. p.403-39.

AUSTIN, B.; CALOMIRIS, J.J.; WALKER, J.D.; COLWELL, R.R.. Numerical taxonomy and ecology of petroleum-degrading bacteria. Appl. Environ. Microbiol., v.34, p. 60-68, 1977.

BALLSCHIMITER, K.; ZELL,M. Analysis of polychlorinated biphenyls (PCB) by glass capillary gas chromatography. Fresenius Z. Anal. Chem., v.302, p.20-31, 1980.

BARKAY, T.; PRITCHARD, H.. Adaptation of aquatic microbial communities to pollutant stress. Microbiol. Sci., v. 5, p. 165-169, 1988.

BEDARD, D.L.. Bacterial transformation of polychlorinated biphenyls: Biological Sciences Laboratory, New York: General Electric, 1990.

BEDARD, D.L.; QUENSEN III; J.F. Microbial reductive dechlorination of Polychlorianted biphenyl. In YOUNG, L.Y.; CERNIGLIA, C. Microbial transformation and degradation of toxic organic chemicals. New York: WileyLiss, 1995. 127-216p. 
BEDARD, D.L.; HARBERL, M.L.; MAY, R.J.; BRENNAN, M.J. Evidence for novel mechanisms of polychlorinated biphenyl metabolism in Alcaligenes eutrophus $\mathrm{H} 850$. Appl. Environ. Microbiol., v.53, p. 1103-1112, 1987b.

BEDARD, D.L.; UNTERMAN R.; BOPP, L.H.; BRENNAN, M.J.; HARBERL, M.L.; JOHNSON, C. Rapid Essay for screening and characterizing microorganisms for the ability to degrade polychlorinated biphenils. Appl. Environ. Microbiol., v.51, p. 761-768, 1986.

BEDARD, D.L.; WAGNER, R.E.; BRENNAN, M.J.; HABERL, M.L., BROWN, J.F. Extensive degradation of Aroclors and environmentally transformed polychlorinated biphenyls by Alcaligenes eutrophus H850. Appl. Environ. Microbiol., v. 53, p. 1103-1112, 1987 a.

BETARCINI, P.V. Biodegradação Bacteriana de bifenilos policlorados (PCBs) na região do estuário Santista. 1998. 87p. Dissertação (Mestrado) - Instituto de Ciências Biomédicas da Universidade de São Paulo. São Paulo.

BÍCEGO, M.C. Contribuição ao estudo de hidrocarbonetos biogênicos e do petróleo no ambiente marinho. 1988. 156p. Dissertação (Mestrado) - Instituto Oceanográfico da Universidade de São Paulo. São Paulo.

BLUMER, M.; MULLIN, M.M.; THOMAS,D.W. Pristane in the marine environment. Helgoländer Wiss. Meersunters., v.10, p.187-200, 1964.

BONETTI FILHO, J. Sensoriamento remoto aplicado à análise de ambientes costeiros impactados - Avaliação metodológica: Baixada Santista. 1996. 260p. Tese (Doutorado) - Departamento de Geografia- Faculdade de Filosofia, Ciências e Letras da Universidade de São Paulo. São Paulo.

BONETTI, C. Foraminíferos como bioindicadores do gradiente de estresse ecológico em ambientes costeiros poluídos. Estudo aplicado ao Sistema estuarino de Santos-São Vicente (SP, Brasil)., 2000. 200p. Tese (Doutorado) - Instituto Oceanográfico da Universidade de São Paulo/Université D’Angers-UFR Sciences. São Paulo/Anger.

BOOP, L.H.. Degradation of highly chlorinated PCBs by Pseudomonas strain LB 400. J.Ind.Microbiol., v.1, p. 23-29, 1986.

BOSCH, R., VALDÉZ, E.G.; MOORE, E.R.B. Genetic characterization and evolutionary implications of a chromosomally encoded naphthalene-degrading upper-pathaway from Pseudomonas stutzeri AN10. Gene, v. 236, p. 149-157, 1999.

BOSCH, R.; VALDÉS, E.G; MOORE, E.R.B. Complete nucleotide sequence and evolutionary significance of a chromosomally encoded naphthalene-degradation lower pathway from Pseudomonas stutzeri AN10. Gene, v. 245, p.65-74, 2000. 
BOSSERT, I.; BARTHA, R. The fate of petroleum in soil ecosystems, p. 434-476. In: ATLAS, R.M. Petroleum microbiology. New York: Macmillan Publishing, 1984.

BOULOUBASSI, I.; SALIOT, A. Dissolved, particulate and sedimentary naturally derived polycyclic aromatic hydrocarbons in a costal environment: geochemical significance.

Mar. Chem., v. 42, p. 127-133, 1993.

BOYLE, A.W.; BLAKE, C.K.; PRICE II, A.; MAY, H.D. Effects of polychlorinated biphenyl congener concentration and sediment supplementation on rates of methanogenesis and 2,3,6-trichlorobiphenyl dechlorination in an anaerobic enrichment, Appl. Envir. Microbiol., v.59, p. 3027-3031, 1993.

BOYLE, A.W.; CHRISTOPHER, S.H.; HASSET, J.P.; NAKAS, J.P.; TANENBAUM, S.W. Bacterial PCB biodegradation. Biodegradation., v. 3, p.285-298, 1992.

BRAGA. E. S; BONETTI, C.; BURONE. L. \& BONETTI FILHO, J. Eutrophication and bacterial pollution caused by industrial and domestic waste at the Baixada Santista estuarine System - Brazil. Mar. Pollut. Bull., v.40, p. 165-173, 2000.

BRENER, W., SOUTHERLAND, S.H.; FOCHT, D.D. Enhanced biodegradation of polychlorinated biphenyls in soil by analog enrichment and bacterial inoculation. $\mathbf{J}$. Environ. Qual., v.14, p. 324-328, 1987.

BRITTON, L.N..Microbial degradation of aliphatic hydrocarbons. In: GIBSON, D.T. Microbial degradation of organic compounds. New York : Marcel Dekker, Inc., 1984. 89-129p.

BROWN, Jr. J.F.; WAGNER, R.E.; BEDARD, D.L.; BRENNAN, M.J.; CARNAHAN, J.C.; MAY, R.M.. PCB transformation in upper Hudson sediments. Northeast.

Environ. Sci., v.3: p.167-179, 1984.

BROWN; J.F.; BEDARD, D.L.; BRENNAN, M.J.; CARNAHAN, J.C.; FENG, H.; WAGNER, R.E. Polychlorinated biphenyl dechlorination in aquatic sediments. Science, v. 236, p. 709-712, 1987.

BRUIJIN, F.J. Use of repetitive (repetitive extragenic palindromic and enterobacterial repetitive intergenic consensus) sequences and the polymerase chain reaction for fingerprinting the genomes of Rhizobium meliloti and other soil bacteria. App. Environ. Microbiol., v. 58, p.2180-2187, 1992.

BUCKLEY, E. N.; JONES, B.; PFAENDER, F.K. Characterization of microbial isolates from an estuarine ecosystem: relationship of hydrocarbon utilization to ambient hydrocarbon concentrations. Appl. Environ. Microbiol., v. 32, p. 232-237, 1976. 
BURNS, K. ; EHRHARDT, M.G.; MCPHEFERSON, J.; TIERNEY, J.; KANANEN, G.; CONNELLY, D. Organic and trace metal contaminants in sdiments, sewater and organisms from two Bermuda Harbours. J. Expl. Mar. Biol.Ecol., v.138, p. 9-34, 1990.

CERNIGLIA, C.E.; GIBSON, D.T. Algal oxidation of aromatic hydrocarbons: formatin of naphthalene by cyanobacteria and microalgae. J. Gen. Microbiol., v.116, p. 495-500, 1979.

CERNIGLIA, C.E.; GIBSON, D.T.; VAN BEILEN, C.. Oxidation of naphthalene by cyanobacteria and microalgae. J. Gen. Microbiol., v.116, p. 495-500, 1980.

CETESB. Apostila do curso de Microbiologia Ambiental. São Paulo: CETESB, 2000. $163 p$.

CETESB. Sistema estuarino de Santos e São Vicente. São Paulo: CETESB, 2001, p.178.

CHANG, S-L.; OH,D.J. University of Minnesota. November 02, 2000.

BBDMaster@mail.ahc.umn.edu, URL: http://umbbd.ahc.umn.edu/cbp/cbp_map.html

CIAPINA, L.P. Diferenciação Genômica de bactérias gram-negativas e gram-positivas pela análise do gene rDNA 16S e rep-PCR. 1997.113p. Dissertação (Mestrado) -

Faculdade de Ciências Agrárias e Veterinárias do Campus de Jaboticabal-

Universidade Estadual Paulista. Jaboticabal, S.P.

CLARK, R.B. Marine Pollution. UK: Claredon Press, 1986.

CLARK, R.C.; BROWN, D.W. Petroleum proprieties and analyze of paraffin hydrocarbons and for interpretation of data bases oil spill effects in aquatic organisms. In: Joint Conference on Prevention and Control of Oil Spills. Washington, D.C., American Petroleum Institute. Resumo em ASFA, 1997.

COMMANDEUR, L.C.M.; VAN EYSEREN, H.E.; OPMEER, M.R.; GOVERS, H.J.; PARSONS, J.R. Biodegradation kinetics of highly chlorinated biphenyls by Alcaligenes sp. JB1 in an aerobic continuous culture system. Environ. Sci. Technol., v.29, p.3038-3043, 1995.

CONNELL, D.W.; MILlER, G.J. Chemisty and Ecotoxicology Pollution. USA: A Wiley-Interscience, 1984. p.43-68 e 228-249.

COONEY, J.J. The fate of petroleum pollutants in fresh-water ecosystems. In: ATLAS, R.M. Petroleum Microbiology. New York: Macmillan, 1984, p.399-434.

COURSEUIL, H.X. Biorremediação acelerada em subsolos contaminados através da inoculação microbiana. Encarte da Revista Bio. Engenharia Sanitária e Ambiental. Ano III, v.3, p. 60-65, 1994. 
EATON, R.W.; CHAPMAN, P.J. Bacterial metabolism of naphthalene: construction and use of recombinant bacteria to study ring cleavage of 1,2-dihydroxynaphthalene and subsequent reactions. J. Bacteriol., v.174, p. 7542-7554, 1992.

EGLINTON, G.; HAMILTON, R.J. Leaf epicuticular waxes. Science, v. 156, p. 1322 1334, 1967.

EHRHARDT, M.; BURNS, K. Hydrocarbons and related photooxidation products in Saudi Arabian Gulf coastal waters and hydrocarbons in underlying sediments and bioindicator bivalves. Mar. Pollut. Bull., v.11, p.187-197, 1993.

ERB, R.W. ; WAGNER-DÖBLER, I.. Detection of polychlorinated degradation genes in polluted sediments by direct DNA extraction and polymerase chain reaction. Appl. Environ. Microbiol., v. 59, p. 4065-4073, 1993.

ERICKSON, J.D.; MONDELLO, F.J. Enhanced biodegradation of polychlorinated biphenyls after site-directed mutagenesis of a biphenyl dioxygenase gene. Appl. Environ. Microbiol., v.59, p. 3858-3862, 1993.

EVANS, S.R. \& RICE, S.D. Effects of oil on marine ecosystems: a review for administrators and policy makers. Fish. Bull., v. 72, p. 625-638, 1974.

FARRINGTON, J.; \& TRIPP, R.W. Hydrocarbons in cores of northwestern Atlantic coastal and continental margin sediments. Estuar. Coast. Mar. Sci., v.5, p. 793-808, 1975.

FAVA, F. The presence of glass beads or Triton X-100 in the medium enhances the aerobic dechlorination of Aroclor 1221 in Pseudomonas sp. CPE 1 Culture. Chemosphere.,v.32, p. 1469-1475, 1996.

FERRERO, M.; LLOBET-BROSSA, E.; LALUCAT, J.; VALDÉS, E.G.; MORA, R.R.; $\mathrm{BOSCH}, \mathrm{R}$. Coexistence of two distinct copies of naphthalene degradation genes in Pseudomonas strains isolated from the western mediterranean region. Appl. Environ. Microbiol., v.68, p. 957-962, 2002.

FIGUEIREDO, L.H.M. Investigação das contribuições orgânicas antrópicas e naturais em sedimentos costeiros utilizando-se hidrocarbonetos marcadores. 1999. 149p. Tese (Doutorado) - Departamento de Química, Pontifícia Universidade Católica do Rio de Janeiro. Rio de Janeiro.

FLOODGATE, G.. The fate of petroleum in marine ecosystems, p. 355-398. In: ATLAS, R.M. Petroleum microbiology. New York: Macmillan, 1984.

FRANTZ B.; CHAKRABARTY A. M. Degradative plasmids in Pseudomonas. In J.R. Sokatch (Ed.): The Bacteria.: The biology of Pseudomonas. New York: Academic Press, 1986. v.10, 295p. 
FUKUDA, M.; YASUKOCHI, Y.; KIKUCHI, Y.; NAGATA, Y.; KIMBARA, K.; HORIUCHI, H.; TAKAGI, M.; YANO, K. Identification of the $b p h A$ and $b p h \mathrm{~B}$ genes of Pseudomanas sp. strains KKS102 involved in degradation of biphenyl and polychlorinated biphenyls. Biochem. Biophys. Res. Commmun., v.202, p. 850-856, 1994.

FÚLFARO, V. J. \& PONÇANO, W. L. Sedimentação atual do estuário e Baía de Santos: um modelo geológico aplicado a projetos de expansão da zona portuária. In: Congresso Brasileiro de Geologia de Engenharia. Anais. Associação Brasileira de Geologia de Engenharia, Rio de Janeiro,1976. v.1. p.67-90.

FULTHORPE, R.R.; RHODES, A.N.; TIEDJE, J.M.. High levels of endemicity of 3chlorobenzoato-degrading soil bacteria. Appl. Environ. Microbiol., v.64, p. 16201627, 1998.

FUNDESPA. Diagnóstico ambiental oceânico e costeiro das regiões sul e sudeste do Brasil. São Paulo: FUNDESPA, 1994.v.3.

FURTADO, V. V.; RODRIGUES, M.; MAHIQUES, M. M. de. Distribuição de sedimentos e matéria orgânica na região de Praia Grande e Baía de Santos (SP): associação com influências antrópicas na área. In: Congresso da ABEQUA $7^{\circ}$, Porto Seguro, BA: 1999.

FURUKAWA, K. Modification of PCBs by bacteria and other microrganisms. Vol 2. In: WAID, J.S. PCBs and the Environment. Florida: CRC Press, 1987. 84p.

FURUKAWA, K. Molecular genetics and evolutionary relationship of PCB-degrading bacteria. Biodegradation, v.5, p.289-300, 1994.

FURUKAWA, K.; HAYASE, N.; TAIRA, K.; TOMIZUKA, N. Molecular relationship of chromosomal genes encoding biphenyl/polychlorinated biphenyl catabolism: some soil bacteria possess a highly conservated bph operon. Appl. Environ. Microbiol. v.171, p. 5467-5472, 1989.

FURUKAWA, K.; MATSUMURA, F., TONOMURA, K. Alcaligenes and Acinetobacter strains capable of degrading polychlorinated biphenyls. Agric. Biol. Chem., v.42, p. 543-548, 1978.

FURUKAWA, K.; TOMIZUKA, N.; KAMIBAYASHI, A. Effect of chlorine substitution on bacterial metabolism of various polychlorinated biphenyls. Appl. Environ. Microbiol., v.38, p.301-310, 1979.

FURUKAWA, K. Modification of PCBs by bacteria and other microrganisms. In : WAID, J.S. PCBs and the Environment. Florida : CRC Press, 1987. v.2, p. 84. 
GELSOMINO, A. KEIJZER-WOLTERS, A.C.; CACCO, G.; VAN ELSAS, J.D. Assessment of bacterial community structure in soil by polymerase chain reaction and denaturing gradient gel eletrophoresis. J. Microbiol. Methods., v.38, p. 1-15, 1999.

GERLACH, S.A. Marine pollution. Diagnosis and therapy. Berlin: Springer Verlag, 1981. 218p.

GESAMP (IMO/FAO/ UNESCO/WMO/IAEA/ UNEP Joint Group of Experts on the Scientific Aspects of Marine Pollution). Impact of Oil and Related Chemicals and wastes on the Marine Environment. Rep. Stud. GESAMP: 50, 1993, 180p.

GIBSON, D.T., CRUDEN, D.L.; HADDOCK, J.D.; ZYLSTRA, G.L.; BRAND, J.M. Oxidation of polychlorinated biphenyls by Pseudomonas sp. strain LB 400 and Pseudomonas pseudoalcaligenes KF707. J. Bacteriol., v.175, p. 4561-4564, 1993.

GIBSON, D.T.; MAHADEVAN, V.; DAVEY, J.F. Bacterial metabolism of para- and meta-xylene: oxidation of the aromatic ring. J. Bacteriol., v.119, p.930-936, 1974.

GILBERT, E.S.; CROWLEY, D.E. Plant compounds that induce polychlorinated biphenyl biodegradation by Arthrobacter sp. strain B1B. Appl. Environ. Microbiol., v.63, p. 1933-1938, 1997.

GREER, C.; MASSON, L.; COMEAU,R.B.; SAMSON, R. Application of Molecular Biology Techniques for Isolating and Monitoring Pollutant-Degrading Bacteria. Water Poll. Res. J. Canada, v.28, p. 275-287, 1993.

GSCHWEND, P.M.; HITES, R.A.. Fluxes of polycyclic aromatic hydrocarbons to marine and lacustrine sediments in the northeastern United States. Geochim. Cosmochim. Acta, v.45, p. 2359-2367, 1981.

GUNTHER, K.; SCHLOSSER, D.; FRITSCHE, W. Phenol and cresol metabolism in Bacillus pumilus isolated from contaminated groundwater. J. Basic Microbiol., v.35, p. 83-92, 1995.

GUTBERLET, J. Cubatão: desenvolvimento, exclusão social e degradação ambiental. São Paulo: Editora da Universidade de São Paulo, FAPESP- São Paulo. 1996.

HAINES, J.R.; ALEXANDER, M. Microbial degradation of high-molecular weight alkanes. Appl. Env. Microbiol., v. 28, p. 1084-1085, 1974.

HAMANN, C.; HEGEMANN, J. HILDEBRANDT, A. Detection of polycyclic aromatic hydrocarbon degradation genes in different soil bacteria by polymerase chain reaction and DNA hybridization. FEMS Microbiol. Lett., v.173, p. 255-263, 1999. 
HAN, J.; CHAN, H.W.S.; CALVIN, M. Biosyntesis of alkanes in Nostoc muscorum. J. Am. Chem. Soc., v.91, p.5156-5159, 1969.

HARAYAMA, S.; KOK, M. Functional and evolutionary relationships among diverse oxygenases. Annu. Rev. Microbiol., v.46, p. 565-601, 1992.

HELENE, M.E.M. Dossiê RHODIA. Informativo ADUSP 13, 1995.

HERNANDEZ, B.S.; ARENSDORF, J.J.; FOCHT, D.D. Characterization of biphenylutilizing isolates which cometabolize PCBs. In: Soil decontamination using biological processes. Karlsruhe: Dechema, 1992. 429-33p.

HERNANDEZ, B.S.; CHIAL, M.; KOH, S.C.; FOCHT, D.D. Plant terpenes are tehe natural substrate for indigenous soil bacteria that utilize biphenyl. Ann. Mtg., Amr, Soc, Microbiol., n.13, 1995. Abstract.

HERRICK, J.B., MADSEN, E.L.; BATT, C.A.; GHIORSE, W.C. Polymerase chain reaction amplification of naphthalene-catabolic and $16 \mathrm{~S}$ rRNA gene sequences from indigenous sediment bacteria. Appl. Environ. Microbiol., v.59, p. 687-694, 1993.

HERRICK, J.B.; STUART-KEIL, K.G.; GHIORSE, W.C.; MADSEN, E.L. Natural horizontal transfer of a naphthalene dioxygenase gene between bacteria native to a coal tar-contaminated field site. Appl. Environ. Microbiol., v.63, p. 2330-2337, 1997.

HIGSON, F.K.; FOCHT, D.D. Degradation of 2-methylbenzoic acid by Pseudomonas cepacia MB2. Appl. Environ. Microbiol., v.58, p.194-200, 1992.

HOLLAWAY, S.L.; FAW, G.M.; SIZEMORE, R.K. The bacterial community composition of an active field in the Northwestern Gulf of Mexico. Mar Pollut. Bull., v.11, p.153$156,1980$.

HOOD, D.W.; FORSTER, W.O.; LINNENBOM, V.; WALDICHUK, M.; PARKER, P.L.; REID, J.L.; TUREKIAN, K.; PERKINS, R. The ultimate fate of substance that relate to the quality of the marine environment. Washington, D.C., National Academy of Sciences. Cap VI: Marine Environmental Quality - Suggested Research Programs for Understanding Man's Effect on the Oceans. 1971, p. 83 - 107

HOOPER, S.W.; PETTIGREW, C.A.; SAYLER, G. Ecological Fate, effects and prospects for the elimination of environmental polychlorinated biphenyls (PCBs). Environ. Toxicol. Chem., v.9, p. 655-667, 1990.

HUTZINGER, O. SAFE, S.; ZITKO, V. The chemistry of PCBs. Cleveland: CRC Press, 1974. 
HYATT, B.H.; OH, D. University of Minnesota. November 02, 2000. BBDMaster@mail.ahc.umn.edu , URL:

http://umbbd.ahc.umn.edu/mxy/mxy_map.html

IPT. Mapa Geomorfológico do Estado de São Paulo. Instituto de Pesquisas Tecnológicas, São Paulo. 1981.

JENSEN, S. The PCB stroy. Ambio, v.1, p. 23-131, 1972.

JONES, J.G.; EDINGTON, M.A. An ecological survey of hydrocarbon-oxidizing microorganisms. J.Gen.Microbiol., v. 52, p. 381-390, 1968.

JONES, J.G.; KNIGHT, M.; BYRON, J.A.Effect of gross pollutionby kerosine hydrocarbons on the microflora of a moorland soil. Nature, v. 227, p.1166, 1970.

JORDAN, R.E.\& PAYNE, J.R. Fate and weathering of petroleum spilled in the marine environment: a literature review and synopsis. Ann Arbor: Ann Arbor Science Publiscers, 1980. p.174.

JORGENSEN, C. NIELSEN, B.; JENSEN, B.K.; MOTENSEN, E. Transformation of oxylene to o-methyl benzoic acid by a denitrifying enrichment culture using toluene as the primary substrate. Biodegradation., v. 6, p. 141-146, 1995.

KA, J.O.; HOLBEN, W.E.; TIEDJE, J.M. Genetic and phenotypic diversity of 2,4dichlorophenoxyacetic acid (2,4-D)-degrading bacteria isolated from 2,4-D-treated field soils. Appl Environ Microbiol., v.60, p.1106-1115, 1994.

KENNISH, M.J. Ecology of estuarines: anthropogenic effects. Boca Raton FL: CRC Press, 1992. $494 \mathrm{p}$.

KIKUCHI, Y.; NAGATA, Y.; HINATA, M.; KIMBARA, K.; FUKUDA, M.; YANO, K.; TAKAGI, M. Identification of the $b p h \mathrm{~A} 4$ gene encoding ferrodoxin reductase involved in the biphenyl and polychlorinated biphenyl degradation in Pseudomonas strain KKS102. J. Bacteriol., v.176, p. 1689-1694, 1994.

KIM, E.; ZYLSTRA, G.J.. Molecular and Biochemical Characterization of two metacleavage dioxigenases involved in biphenyl and $m$-xylene degradation by Beijerinckia sp. Strain B1. J. Bacteriol., v.177, p. 3095-3103, 1995.

KIMBARA, K.; HASHIMOTO, T.; FUKUDA, M. KOANA, T.; TAKAGI, M.; OISHI,M.; YANO,K. Isolation and characterization of a mixed culture that degrades polychlorinated biphenyls. Agric. Bio. Chem., v.52, p.2885-2891, 1988.

KIMBARA, K; HASHIMOTO, T.; FUKUDA,M. KOANA, T.; TAKAGI, M.; OISHI, M.; YANO, K. Cloning and sequencing of two tandem genes involved in degradation of 
2,3-dihydroxibiphenyl-degrading soil bacterium Pseudomonas sp. Strain KKS12. J. Bacteriol., v.171, p. 2740-2747, 1989.

KINBROUGH, R.D.; SQUIRE, R.H.; LINDER, R.E.; STRANDBERG, J.D; MONTALI. APUDABRAMOWICZ, D.A. Aerobic and anaerobic biodegradation of PCBs. Biotechnology, v.10, p. 24, p. 241-250, 1990.

KIRK, P.W.; GORDON, A.S. Hydrocarbon degradation by filamentous marine higher fungi. Mycologia., v. 80, p. 776-782, 1988.

KOHLER, H.P.; KOHLER-STAUB, D. FOCHT, DD. Cometabolism of Polychlorinated biphenyls: enhanced transformation of Aroclor 1245 by growing bacterial cells. Appl. Environ. Microbiol., v.54, p.1940-1945, 1988.

KOK, M.; OLDENHUIS, R.; VAN DER LINDEN, M.P.; RAATJES, P.; KINGMA, J.; VAN LELYVELD, P.H..; WITHOLT, B. The Pseudomonas oleovorans alkane hydroxylase gene. J. Biol. Chem., v.264, p.5435-5441,1989.

KOSONO, S.; MAEDA, M.; FUGI, F.; ARAI, H.; KUDO, T.. Three of the seven $b p h \mathrm{C}$ genes of Rhodoccocus erythropolis TA421, isolated from a Termite ecosystem, are located on an indifenous plasmid associated with biphenyl degradation. Appl.

Environ. Microbiol., v.63, p.3282-3285, 1997.

KUMAMARU, T.; SUENAGA, H.; MITSUOKA, M.; WATANABE, T.; FURUKAWA, K. Enhanced degradation of polychlorinated biphenyls by directed evolution of biphenyls dioxygenase. Nature Biotech., v.16, p.663-666, 1998.

KURKELA, S.; LEHVASAIHO, H. PALVA, E.T.; TEERI, T.H. Cloning, nucleotide sequence and characterization of genes enconding naphthalene dioxygenase of Pseudomonas putida strain NCBIB9816. Gene, v.73, p.355-362, 1988.

LAEMMLI, C.M.; LEVEAU, J.H.J.; ZEHNDER, A.J.B.; VAN DER MEER, J.R.. Characterizationof a second $t f d$ gene cluster for chlorophenol and chlorocatecol metabolism on plasmid pJP4 in Ralstonia eutropha JMP134(pJP4). J. Bacteriol., v.182, p. 4165-4172, 2000.

LANE, D.J. In: Stackebrandt, E. \& Goodfellow, M. Nucleic Acid Techniques in Bacterial Systematics,. England, Chichester: John Wiley \& Sons, 1991. 
LANGENHOFF, A.A.M.; ZEHNDER, J.B.; SCHRAA, G. Behavior of toluene, benzene and naphthalene under anaerobic conditions in sediment columns. Biodegradation, v.7, p.267-274, 1996.

LARA, W.H. Bifenilas Policloradas - sua história e seus problemas. Congresso de Toxicologia Tropical, 1. 11-14 abril 1976, Manaus. In: Anais. Sociedade Brasileira de Toxicologia/ Alatox, Manaus, 1976. p.181-185.

LARA, W.H.; BARRETO, H.H.; INOMATA, O.N.K.; MONTONE, R.C.; WEBER, R.R. Organochlorine residues in antarctic penguins. Pesq. Antártica Bras., v.2, p. 1-6, 1990.

LARAMÉE, L.; LAWRENCE, J.R.; GREER, C.W. Molecular analysis and development of $16 \mathrm{~S}$ rRNA oligonucleotide probes to characterize a dicloro-methyl-degrading biofilm consortium. Can. J. Microbiol., v. 46, p.133-42, 2000.

LARSSON, P. Contaminated sediments of Lakes and oceans act as sources or chlorinated hydrocarbons for realease to water atmosphere. Nature, v. 317, p. 347-349, 1985.

LAUBER, J. D. Disposal and destruction of waste PCBs. In: WAID, J.F. (Ed.). PCBs in the environment. Florida: CRC Press, 1987. v.1. 79-101p.

LAW; R.J. Polychlorinated biphenyls in sediments downstream of a contaminated industrial site in North Wales. Mar. Pollut. Bull., v.22, p.492-493, 1991.

LAWS, E. A. Aquatic Pollution. An Introductory Text. USA, An Interscience Publication. Cap. 01; p. 01 - 18: Fundamental Concepts. Cap 8; p. 179 - 218: Toxicology. Cap 13; p. 417 - 458: Oil Pollution, 1993.

LEAHY, J.F. \& COLWELL, R.R. Microbial Degradation of Hydrocarbons in the Environmental. Microb. Rev., v.54 , p. 305-315, 1990.

LORENZ, M.G.; WACKERNAGEL, W. Bacterial gene transfer by natural genetic transformation in the environment. Microbiol. Rev., v.58, p. 563-602, 1994.

LOUWS, F.J. Specific genomic fingerprints of phytopathogenic Xanthomonas e Pseudomonas pathovars and strains generated with repetitive sequences and PCR. Appl. Environ. Microbiol., v. 60, p.2286-2295, 1994.

LUZ, .A.P. Biodiversidade e Dispersão de Genes Catabólicos de Microrganismos Degradadores de Compostos Xenobióticos no Solo. 2001. 103p. Tese (Doutorado) Instituto de Ciências Biomédicas da Universidade de São Paulo. São Paulo

LYNCH, J. M.; HOBBIE, J.E., Micro-organisms in Action: Concepts and Applications in Microbial Ecology. Oxford: Blackwell Scientific Publications, 1988. 322-347pp. 
MacFARREN, E.F.; LISHKA, R.J.; PARKER, J.H. Criterion for jugding acceptability of analytical methods. Analyt. Chem., v.42, p. 358-65, 1970.

MAHER, W.A.; AISLABIE, J. Polycyclic Aromatic Hydrocarbons in near shore marine sediments of Australia. Sci. Total Enviroment, v.112, p.143-164, 1992.

MANAHAN, S. E. Fundamentals of environmental chemistry. Michigan: Lewis Publishers, 1993. 438p.

MASAI, E.; YAMADA, A.; HEALY, J.M.; HATTA, T.; KIMBARA, K.; FUKUDA, M.; YANO, K. Characterization of biphenyl catabolic genes of Gram-positive polychlorinated bipheyl degrader Rhodoccocus sp. strain RHA1. Appl. Environ. Microbiol., v.61, p. 2079-85, 1995.

MASON, J.R.; CAMMACK, R. The electron-transport proteins of hydroxylationg bacterial dioxygenases. Annu. Rev. Microbiol., v.46, p. 277-305, 1999.

MAY, H.D.; BOYLE, A.W.; PRICE II, W.A.; BLAKE, C.K. Subculturing of a polychlorinating anaerobic enrichment on solid media. Appl. Env. Microbiol., v.58, p.3088-3094, 1992.

McELROY, A.E.; FARRINGTON, J.W.; TEAL, J.M. Bioaviability of polycyclic aromatic hydrocarbons in the aquatic environment. In: VARNASI, U. Metabolism of polycyclic aromatic hydrocarbons in the aquatic environment. USA: CRC press Boca Ranton, 1989. p.1-39.

McKENNA, E.J.; KALLIO, R.E. hydrocarbon structure: its effects on bacterial utilization of alkanes. In: HEUKEKIAN, H.; DONDERO, N.C. Principles and application in aquatic microbiology. New York: John Wiley, 1964. p.1-14.

MEDEIROS, P. M. Avaliação da origem de hidrocarbonetos em sedimentos marinhos de Santos e São Sebastião, utilizando-se hidrocarbonetos marcadores geoquímicos. 2000. 102p. Dissertação (Mestrado) - Instituto Oceanográfico da Universidade de São Paulo. São Paulo.

MENDES, J.C. Elementos de Estratigrafia. São Paulo: Editora da Universidade de São Paulo, 1984.566p.

MESARCH, M.B.; NAKATSU, C.H.; NIES, L. Development of catechol 2,3dioxygenase-specific iniciadors for monitoring bioremediation by competitive quantitative PCR. Appl. Environ. Microbiol., v.66: 678-683, 2000.

MESARCH, M.B.; NIES, L. Modification of heterotrophic plate counts for assessing the bioremediation potential of petroleum-contaminated soils. Environ. Technol., v.18, p. 639-646, 1997. 
MILANELLI, J.C.C. Efeitos do petróleo e da limpeza por jateamento de um costão rochoso da Praia de Barequeçaba, São Sebastião, São Paulo. 1994. 103p. Dissertação (Mestrado) - Instituto Oceanográfico da Universidade de São Paulo. São Paulo.

MILLER , T.L.; JOHNSON, M.J. Utilization of normal alkanes by yeasts. Biotech. \& Bioeng., v.8, p.549-565, 1966.

MILLERO, F.J.; SOHN, M.L. Chemical Oceanography. Florida USA: Boca Raton. FL: CRC Press, 1991. 531p.

MONDELLO, F.J. Cloning and expression in E. coli of Pseudomonas strain LB 400 genes encoding polychlorinated biphenyl degradation. J. Bacteriol., v.171, p.1725-1732. 1989.

MONTONE, R.C. Determinação de bifenilos policlorados (PCBs) no ambiente antártico marinho. 1995. 98p. Tese (Doutorado) - Instituto de Química, Universidade de São Paulo. São Paulo.

MONTONE, R.C. Hidrocarbonetos clorados no litoral do estado de São Paulo.1987. 112p. Dissertação (Mestrado) - Instituto Oceanográfico da Universidade de São Paulo. São Paulo.

MONTONE, R.C.; WEBER, R.R. Ocorrência de pesticidas organoclorados e bifenilos policlorados em organismos marinhos do litoral de São Paulo e Ubatuba, S.P. Plub. Esp. Inst. Ocean. v.11, p.87-90, 1995.

MORGAN, P.; WATKINSON, R.J. Biodegradation of components of petroleum. In: RATLEDGE, C. Biochemistry of Microbial Degradation. London: Kluwer Academic, 1994. 509p.

MORRISON, R.; BOYD, R. Química Orgânica, 12a, Fundação Calouste Gulbekian. 1995.

MOSQUEDA, G.; RAMOS, J.L. A set of genes encoding a second toluene efflux system in Pseudomonas putida DOT-T1E is linked to the tod genes for toluene metabolism., $\mathbf{J}$. Bacteriol., v. 182 p.937-943, 2000.

MULKINS-PHILLIPS, G.J.; STEWART, J. E.. Distribution of hydrocarbon-utilizing bacteria in northwestern Atlantic waters and coastla sediments. Can. J. Microbiol. v.20, p.955-962, 1974.

MURRAY, K.; DUGGLEBY, C.J.; SALA-TREPAT, J.M.; WILLIAMS, P.A. The metabolism of benzoate and methylbenzoates via meta-cleavage pathway by Pseudomonas arvilla mt-2. Eur. J. Biochem., v.28, p.301-10, 1972. 
MUYER, G. Structure, Function and Dynamics of Microbial Communites: The Molecular Biological Approach. In: CARVALHO, J.R. Advances in Molecular Ecology. Amsterdam, Berlim, Oxford, Tokyo, Washington D.C. (Published in cooperation with NATO Scientific Affairs Division): IOS press; 1998. p.87-117.

NADIN, L.M.; SCHOCKEN, M.J.; HIGSON, F.K.; GISON, D.T.; BEDARD, D.L.; BOOP, L.H.; MONDELLO, F.J. Bacterial oxidation of polychlorinated biphenyls. In: Annual research symposium on land disposal, remedial action, incineration and treatment of hazardous waste. Cincinati: EPA, 1987. 395p.

NAKAI, C.; KAGAMIYAMI, H.; NOZAKI, M.; NAKAZAWA, T.; INOUYE, S.; EBINA, E.; NAKAZAWA, A. Complete nucleotide sequence of the metapyrocatechase gene on the TOL plasmid of Pseudomonas putida mt-2. J. Biol. Chem., v.258, p. 29232928, 1983.

NEI, M. Molecular evolutionary genetics. New York: Columbia University Press, 1987. $512 p$.

NIPPER, M.G. Problemas de poluição em organismos bentônicos. In: II Simpósio de Ecossistemas da Costa Sul e Sudeste Brasileira. Estrutura, Função e Manejo. Publicação ACIESP n. 71-3. Resumos, v. 03, p. 24 - 42,1990.

NOGALES, B.; MOORE, E. R. B. ; BROSSA, E. L.; MORA, R.R.; AMANN, R.; TIMMIS, K.N. Combined use of $16 \mathrm{~S}$ ribosomal DNA and 16S rDNA to study the bacterial community of Polychlorinated Biphenyl- Polluted Soil. Appl. Env. Microbiol., v.67, p. 1874-1884, 2001.

NOGUEIRA, D.P.; SOUZA, J.M.P.; COLACIOPPO, S.; GOMES, J.R.; BRANDÃO, J.B.B.; SOUZA, M.L.A. Acúmulo de policloretos de bifenila na população da grande São Paulo. Rev. Saúde Públ., S. Paulo, v.21, p. 279-290, 1987.

NRC ( NATIONAL RESERCH COUNCIL.) Oil in the sea, inputs, fates and effects. Washington D.C.: National Academy Press, 1985. 602p.

OH, D. J. University of Minnesota. November 03, 2000. BBDMaster@,mail.ahc.umn.edu, URL:http://umbbd.ahc.umn.edu/oxy/oxy_image_map.html 2000

OHTSUBO, Y; NAGATA, Y.; KIMBARA, K.; TAKAGI, M.; OHTA, A. Expression of the $b p h$ genes involved in biphenyl/PCB degradation in Pseudomonas sp. KKS 102 induced by the biphenyl degradation intermediate, 2-hydroxy-6-oxo-6-phenylhexa2,4, dienoic acid. Gene, v.256, p.223-228, 2000. 
PARALES, R. E.; DITTY, J.L.; HARWOOD, C.S. Toluene-degrading bacteria are chemotactic toward the environmental pollutants benzene, toluene and trichlorenthylene. Appl. Env. Microbiol., v.66, p. 4098-4104, 2000.

PELLIZARI, V.H.. Aspectos moleculares e fenotípicos de bactérias isoladas do ambiente e envolvidas na biodegradação de bifenilos policlorados -PCBs. 1995. 67p. Tese (Doutorado) - Instituto de Ciências Biomédicas da Universidade de São Paulo. São Paulo.

PELLIZARI, V.H.; BEZBORODNIKOV, S.; QUENSEN III, J.F.; TIEDJE, J.M. Evaluation of naphtalene and biphenyl isolated for hybridization to dioxygenase probes and PCB degrading ability. Appl. Environ. Microbiol., v.62, p. 2053-2058, 1996.

PERKINS, E.J.; GORDON, M.P.; CACERES, O.; LURQUIN, P.F. Organization and sequence analysis of the 2,4-dichlorophenol hydroxylase and dichlorocatechol oxidative operons of plasmid pJP4. J. Bacteriol., v.172, p.2351-2359, 1990.

PETROV,A.A. Petroleum hydrocarbons. New York, London, Paris, Tokyo: Springer Verlag, Heidelberg, 1986. 255p.

PHIBBS, P. EPA reassesment finds as much as 20 times less cancer riak from PCBs. Environ. Science \& Technol., v.30, p.23-24,1996.

PINHOLT, Y.; STRUWE, S.; KJOLLER, A. Microbial changes during oil decomposition in soil. Holarct. Ecol., v.2: p.195-200, 1979.

POELARENDS, G.J.; KULAKOV, L.A.; LARKIN, M.J.; VLIEDG, J.E.T.H.; JANSSEN, D.B. Roles of horizontal gene transfer and gene integration in evolution of 1,3dichloropropene- and 1,2-dibromoethane-degradative pathway. J.bacteriol., v.182, p. 2191-2199, 2000.

PONÇANO, W.L.; FÚLFARO, V.J. Sedimentação atual nas adjacências da Ponta de Itaipu e Baía de Santos: implicações na escolha de locais de lançamento de material dragado. In: Congresso Brasileiro de Geologia de Engenharia, 1976. v.1, p. 91100 .

POOLE, L.B. Flavin-dependent alkyl hydroperoxide reductase from Salmonella typhimurium. 2. Cystine disulfides involved in catalysis of peroxide reduction. Biochemistry, v.35, p.65-75, 1996.

PRATS, B. Polychlorinated biphenyls and organochlorine pesticides in marine sediments in the sea water along the coast of Alicante, Spain. Mar. Poll. Bull., v. 24, p.441-446 1992. 
PRITCHARD, P.H.; MUELLER, J.G.; LANTZ, S.E.; SANTAVY, D.L. The potential importance of biodiversity in environmental biotechnology applications: bioremediation of PAH-contaminated soils and sediments. In: ALLSOPP, D.; COLWELL, R.R.; HAWKSWORTH, D.L. Microbial Diversity and Ecosystem Function. Proceed. IUBS/IUMS Workshop, UK, 10-13 August 1993 in support of the IUBS/UNESCO/SCOPE “Diversity” Programme. Cab. International, UK, 1996. $481 \mathrm{p}$.

QUENSEN III, J.F.; TIEDJE, J.M.; BOYD, S.A.A. Dechlorination of four commercial polychlorinated biphenyl mixtures (Aroclor) by anaerobic microorganisms from sediments. Appl. Environ. Microbiol., v.56, p.2360-2369, 1990.

RAJENDRAN, N.; MATSUDA, O.; SAKOH, H. Comparison of microbial community structure in surface of sediments of Saroma Ko lagoon with Seto Inland sea in winter. Proc. NIPR Symp. Polar Biol., v.8, p.37-47, 1995.

RATAJCZAK, A.; GEIBDÖRFER, W.; HILLEN, W.. Alkane hydroxylase from Acinetobacter sp. strain ADP1 is encoded by alkM and belongs to a new family of bacterial integral-membrane hydrocarbon hydroxylases. Appl. Environ. Microbiol., v.64, p.1175-1179, 1998.

RIBEIRO NETO, F. B. \& OLIVEIRA, M. F. Estratégias de sobrevivência de comunidades litorâneas em regiões ecologicamente degradadas: o caso da Baixada Santista. Programa de Pesquisa e Conservação de Áreas Úmidas no Brasil/Fundação Ford/UICN/IO-USP, São Paulo, 1989. 132p.

RISEBROUGHT, R.W. PCB and PCP contamination in Winter Quarters Bay, Antarctica. Mar. Pollut. Bull., v. 21, p. 523-529, 1990.

ROACH, J.A.G. Nonmetabolic alteration of PCBs. In: WAID, J.F. PCBs in the environment. Florida: CRC Press, 1987. v.1, p. 207-214.

ROCHKIND - DUBINSKY, M.L.; SAYLER, G.S.; BLACKBURN, J. Microbiological decomposition of chlorinated aromatic compounds. NY and Basel: Marcel Dekker, 1987.

SANTOS, E. O. Características climáticas. In: AZEVEDO, A. A Baixada Santista: aspectos geográficos. Vol. 1 - As Bases Físicas. São Paulo: EDUSP, 1965. 156p.

SAWHNEY, B.L. Chemistry and properties of PCBs in realtion to environmenttal effects. Vol. 3 In WAID, J.S. PCBs and the environnent. Florida: CRC Press Inc., 1987. $47 \mathrm{p}$.

SAYLER, G.S., M.S. SHIELDS., E. T. TEDFORD, A. BREEN, S. W. HOOPER, K.M. SIROTKIN, J.W. DAVIS. Application of DNA-DNA colony hybridization to the detection of catabolic genotypes in environmental samples. Appl. Environ.

Microbiol., v. 49, p.1295-13031985. 
SCHAEFFER, T.L.S.; CANTWELL, S.G.; BROWN, J.L.; WATT, D.S.; FALL, R.R. Microbial growth on hydrocarbons: terminal branching inhibits biodegradation. Appl. Envir. Microbiol., v.38, p.742-746, 1979.

SCHAEFFER-NOVELLI, Y. Vulnerabilidade do litoral norte do Estado de São Paulo a vazamentos de petróleo e derivados. In:Simpósio de Ecossistemas da Costa Sul e Sudeste Brasileira. Estrutura, Função e Manejo, 2º ${ }^{\circ}$, Publicação ACIESP n. 71 2, 1990. v.2, Resumos, p. $375-399$.

SCHAEFFER-NOVELLI, Y.; LACERDA, L.D. Manguezais - Vulnerabilidade do litoral à derramamentos de óleo. Diagnóstico Ambiental Oceânico e Costeiro das Regiões Sul e Sudeste do Brasil. São Paulo: FUNDESPA - Fundação de Estudos e Pesquisas Aquáticas, 1992.v.1, p. 99 - 109.

SKINNER, B.J.; TUREKIAN, K.K. O homem e o oceano. São Paulo: Edgard Blucher, 1977.

SMALLA, K.; CRESSWELL, N. MENDONÇA-HAGLER, L.C.; WOLTERS, A.; VAN ELSAS, J.D.. Rapid DNA extraction protocol from soil for polymerase chain reaction-mediated amplification, J. Appl. Bacteriol., v.74, p.78-85, 1993.

SMITH, M.R. The physiology of aromatic hydrocarbon degrading bacteria. In: RATLEDGE, C. Biochemistry of microbioal degradation. London: Kluwer Academic, 1994. 590p.

SMITS T.H.M., BALADA, S.B.; WITHOLT, B.; VAN BEILEN, J.B. Functional analysis of alkane hydroxylases from Gram-negative and Gram- positive bacteria. J. Bacteriol., v.184, p.1733-1742, 2002.

SMITS, T.H.M.; RÖTHLISBERGER, M.; WITHOLT, B.; van BEILEN, J.B. Molecular screening for alkane hydroxylase genes in Gram-negative and Gram-positive strains. Environ. Microbiol., v.1, p. 307-317. 1999.

SNEDAKER, S.C.; GLYNN, P.W., RUMBOLD, D.G.; CORCORAN, E.F. Distribuition of n-alkanes in marine samples from southeast Florida. Mar. Pollut. Bull., v.30, p. 83-89 1995.

SPAIN, J.C.; P.A. VAN VELD. Adaptation of natural microbial communities to degradation of xenobiotic compounds: effects of concentration, exposure time, inoculum, and chemical structure. Appl. Environ. Microbiol., v. 54, p.428-435, 1983.

SPEER, G.C.; WHITHEHEAD, E.V. Crude petroleum. In: EGLINGTON, G. \& MURPHY, N.T.J. Organic Geochemistry. Berlin: Springer - Verlag, 1969. p.638675. 
SPRINGAEL, D.; KREPS, S.; MERGEAY, Identification of a catabolic transposon, Tn4371, carrying biphenyl and 4-chlorobiphenyl degradation genes in Alcaligenes eutrophus A5. J. Bacteriol., v.175, p.1674-1681, 1993.

STALEY, J. T. \& GOSINK, J.J. Poles apart: biodiversity and biogeography of sea ice bacteria. Annu. Rev. Microbiol., v.53, p.189-215, 1999.

STALEY, J.T.Bacterial biodiversity: a time for place. ASM News, v. 65, p. 681-687, 1999.

STEINHAUER, M.S. \& BOEHM, P.D. The compositon and distribuition of saturated and aromatic hydrocarbons in nearshore sediments, river sediments, and coastal peat of Alaskan Beaufort Sea: implications for detecting anthropogenic hydrocarbon inputs. Mar. Environ. Res., v.33, p. 223-253, 1992.

STEPHENS, S. University of Minnesota. December 09, 2001 BBDMaster@mail.ahc.umn.edu, URL: http://umbbd.ahc.umn.edu/pxy/pxy_image_map.html

STUART-KEIL, K.G.; HOHNSTOCK, A.M.; DREES, K.P.; HERRICK, J.B.; MADSEN, E.L. Plasmids responsible for horizontal transfer of naphthalene catabolism genes between bacteria at a coal tar-contaminated site are homologous to pDTG1 from Pseudomonas putida NCIB 9816-4, Appl. Environ. Microbiol., v.64, p.3633-3640, 1998.

TAIRA, K.; HIROSE, J.; HAYASHIDA, FURUKAWA, F. Analysis of bph operon from the polychlorinated biphenyl-degrading strain of Pseudomonas pseudoalcaligenes KF 707. J. Biol. Chem., v.267, p.4844-4853, 1992.

TANABE, S. PCB problems inthe future: foresight from current knowledge. Environ. Pollution, v.50, p. 5-28, 1988.

TANABE, S.; HIDAKA, H.; TATSUKAWA, R. PCBs and chorinated hydrocarbons pesticides in antarctic atmosphere and hydrosphere. Chemosphere, v.12, p. 277-288, 1983.

TANIGUCHI, S. Pesticidas organiclorados e bifenilos policlorados em bivalves ao long da costa brasileira - International Mussel Watch. 1995. 65p. Dissertação (Mestrado) Instituto Oceanográfico da Universidade de São Paulo. São Paulo.

TAVARES, T.M.; ROCHA, V.C.; PORTE, C.; BARCELS, D.; ALBAIGIS, J. Application of the Mussel Watch concept in studies of hydrocarbons, PCBs and DDT in the Brasilian Bay of Todos os Santos (Bahia). Mar. Pollut. Bull., v.19, p.575-578, 1988. 
TIEDJE, M.J TIEDJE; FULTHORPE, R.R.; RHODES, A.; BEZBORODNIKOV,S.; PELLIZARI, V.H.; Molecular Biogeography: How uniform is microbial dispersion? Workshop on Molecular Ecology. Alemanha 1994.

TOMMASI, L.R. Resíduos de praguicidas em águas e sedimentos de fundo do sistema estuarino de Santos (SP). Ciên. Cult., v.37. p.1001-1012, 1985.

TORSVIK, V.; DAAE, F.L.; SANDAA, R.A.; ØVREÅS, L. Novel techniques for analysing microbial diversity in natural and perturbed environments. J. Biotechnol., v. 64, p. 53-62, 1998.

UNEP(UNITED NATIONS ENVIRONMENT PROGRAMME). Determinetions of petroleum hydrocarbons in sediments. Reference methods for marine pollution studies n⿳0 20. 1991, p.97.

VAN BEILEN, J.B., PANKE, S.; LUCCHINI, FRANCHINI, A.G; RÖTHLISBERGER, M.; WITHOLT, B. Analysis of Pseudomonas putida alkane degradation gene clusters and flanking insertion sequences: evolution and regulation of the alk-genes.

Microbiology, v.147, p.1621-1630, 2001

VAN BEILEN, J.B.; WUBBOLTS, M.G.; WITHOLT, B.Genetics of alkane oxidation by Pseudomonas oleovorans, Biodegradation., v. 5, p.161-174, 1994.

VAN DER LINDEN, A.C.; THIJSSE, G.J.E. The mechanism of microbial oxidations of petroleum hydrocarbons. Adv.Enzymol., v.27, p.469-546, 1965.

VAN DER MEER, J.R.; DE VOS, W.M.; HARAYAMA, S.; ZEHNDER, A.J. Molecular mechanisms of genetic adaptation to xenobiotic compounds. Microbiol. Rev., v.56, p. 677-694, 1993

VEDLER, E.; KÕIV, V.; HEINARU, A. TfdR, the Lys R-type transcriptional activator, is responsible for the activation of the $t f d \mathrm{CB}$ operon of Pseudomonas putida 2,4dichlorophenoxyacetic acid degradative plasmid pEST4011. Gene, v.245, p.161-168, 2000 .

VERSALOVIC, J. SCHNEIDER, M.; DE BRUIJN, J.F.; LUPSKI, J.R. Genomic Fingerprint of Bacteria using repetitive sequence -based Polymerase Chain Reaction. Methods Mol. Cel. Biol., v. 5, p. 25-40, 1994.

VERSALOVIC, J.; KOEUTH, T.; LUPSKI, J.R. Distribution of repetitive DNA sequences in eubacteria and application to fingerprint of bacterial genomes. Nucleic Acids Res., v.19, p. 6823-6831, 1991.

VOLKMAN, J.K.; HOLDSWORTH, G.D.; NEILL, G.P. \& BAVOR, H.J.Jr. Identification of natural, anthropogene and petroleum hydrocarbons in aquatic sediments. Sci. total Environ., v.112, p.203-219, 1992. 
WAID, J.F. PCBS and the environment. Vols 1,2,3. CRC Press Inc., Boca Raton, 1986 apud BOYLE, A. SILVIN, C.J.; HASSET, J.P.; NAKAS, J.P.\& TANENBAUM, S.W. Bacterial PCB biodegradation. Biodegradation, v.3, p. 285-298, 1992.

WALKER, J.D.; COLWELL, R.R.L PETRAKIS, L. Biodegradation of petroleum by Chease peake Bay sediment bacteria. Can. J. Microbiol., v. 22, p. 423-428, 1976.

WARD, D.M.; BROCK, T.D. Environmental factors influencing the rate of hydrocarbon oxidation in temperature lakes. Appl. Environ. Microbiol., v. 31, p.764-772, 1976.

WEBER, R.R. Hidrocarbonetos no ambiente marinho - aspectos analíticos e ambientais. 1981. 178p. Tese (Doutorado) - Instituto de Química da Universidade de São Paulo. São Paulo.

WERLEN, C.; KOHLER, H.P.; VAN DER MEER, J.R.. The broad substrate chlorobenzene dioxigenase and cis-chlorobenzene dihydrodiol dehydrogenase of Pseudomonas sp. strain P51 are linked evolutionarily to the enzymes for benzene and toluene degradation . J. Biol. Chem., v.271, p. 4009-4016, 1996.

WHO (WORLD HEALTH ORGANIZATION) Polychlorinated Biphenyls and Terpheyls. Geneva: World Health Organization (Environmental Health Criteria 2). 1976.

WHYTE, L.G.; BOURBONNIÈRE, L.; BELLEROSE, C.; GREER, C.W. Biorremediation assessment of hydrocarbon-contaminated soils from the high Arctic. Bioremediation, v.3, p. 69-79, 1999b.

WHYTE, L.G.; BOURBONNIÈRE, L.; GREER, C.W. Biodegradation of Petroleum hydrocarbons by Psychrotrophic Pseudomonas strains possessing both alkane (alk) and Naphtahalene (nah) Catabolic Pathways. Appl. Env. Microbiol., v.63, p. 37193723, 1997.

WHYTE, L.G.; GREER, C.W.; INNISS, W.E. Assessment of the biodegradation potential of psychrotrophic microorganisms. Can. J. Microbiol., v.42, p.99-106, 1996.

WHYTE, L.G.; HAWARI, J.; ZHOU, E.; BOURBONNIÈRE, L.; INNISS, W.E.; GREER, C.W. Biodegradation of variable-chain-length alkanes at low temperatures by a psychrotrophic Rhodococcus sp. Appl. Environ. Microbiol., v.64, p.2578-84, 1998.

WHYTE, L.G.; SMITS, T.; LABBÉ, D.; WITHOLT, B.; GREER, C.W.; VAN BEILEN, J. Cloning and Characterization of multiple alkane hydroxilases in Rhodoccocus sp. strains 16531 and Q15., 2001b (submetido a Appl. Environ Microbiol.). 
WIKSTRÖM, P.; WIKLUND, A.; ANDERSSON, A.-C.; FORSMAN, M. DNA recovery and PCR quantification of catechol 2,3-dioxygenase genes from different soils types.

J. Biotechnol., v. 52:107-120, 1996.

WILLIAMS, A.W. Stimulation and Enrichment of two microbial Polychorinated biphenyl reductive dechlorination activities. Chemosphere, v.34, p.655-669, 1997.

WILLS, D.; STEPHEN, S.; BRYAN, E. University of Minnesota, November 03, 2000 BBDMaster@mail.ahc.umn.edu, URL:

http://umbbd.ahc.umn.edu/oct/oct_image_map.html

WITT, G.; TROST, E. Polycyclic aromatic hydrocarbons (PAHs) in sediments of the baltic sea and of the german coastal waters. Chemosphere, v.38, p.1603-1614, 1999.

WU, O.; BEDARD, D.L.; WEIGEL, J. Effect of Incubation Temperature on the route of Microbial Reductive Dechlorination of 2,3,4,6- Tretrachlorobiphenyl in Polychlorinated Biphenyl (PCB)- Contaminated and PCB-Free Freshwater Sediments. App. Env. Microbiol., v.63, p.2836-2843, 1997.

WU, O.; BEDARD, D.L.; WEIGEL, J. Influence of Incubation Temperature on tehMicrobial Reductive Dechlorination of 2,3,4,6- Tretrachlorobiphenyl in two Freshwater Sediments. Appl. Envir. Microbiol., v. 62, p.4174-4179, 1996.

YADAV, J.S.; QUENSEN III, J.F.; TIEDJE, J.M.; REDDY, C.A. Degradation of polychlorinated biphenyls mixtures (Aroclors 1242, 1254, and 1260) by the white rot fungus Phanaerochate chrysosporium as evidence by congener-specific analysis.

Appl. Environ. Microbiol., v.61, p.2560-2565, 1995.

YANG, G.P. Polycyclic aromatic hydrocarbons in the sediments of the South China Sea.

Env. Pollut., v.108, p.163-171, 2000.

YE, D., QUENSEN III, J.F.; TIEDJE, J.M.; BOYD, S.A. Evidence for par dechlorination of polychlorinated biphenyls by methanogenic bacteria. Appl. Environ. Microbiol., v.61, p. 2166-2171, 1995.

ZAITSEV, G.M.; TSOI, T.V.; GRISHENKOV, V.G.; PLOTNIKOVA, E.G.; BORONIN, A.M.. Genetic Control of degradation of chlorinated benzoic acid in Arthrobacter globiformis, Corynebacterium sepedonicum and Pseudomonas cepacia strains. FEMS Microbiol. Lett., v.81, p.171-176, 1991.

ZANARDI, E. Hidrocarbonetos no Canal de São Sebastião e na plataforma interna adjacente - influência do derrame de maio de 1994. 1996. 112p. Dissertação (Mestrado) - Instituto Oceanográfico da Universidade de São Paulo. São Paulo.

ZENG, Y. University of Minnesota. December 09, 2001 BBDMaster@mail.ahc.umn.edu, URL: http://umbbd.ahc.umn.edu/tol/tol_map.html 
ZHENG, G.J.; RICHARDSON, B.J. Petroleum hydrocarbons and polycyclic aromatic hydrocarbons (PAHs) in Hong Kong Marine sediments. Chemosphere, v.38, p. 26252632, 1999.

ZYLSTRA, G.J.; GIBSON, D.T. Toluene Degradation by Pseudomonas putida F1. J. Biol. Chem., v.25, p.14940-14946, 1989.

ZYLSTRA,G.J.; GIBSON, D.T. Aromatic hydrocarbon degradation: a molecular approach. Genet. Eng., v.13, p. 183-203, 1991. 